\title{
ENVIRONMENTAL DIAGNOSTIC ANALYSIS OF GROUND WATER BACTERIA AND THEIR INVOLVEMENT IN UTILIZATION OF AROMATIC COMPOUNDS (U)
}

by WSRC Contact - T. C. Hazen

Westinghouse Savannah River Company

Savannah River Site

Aiken, South Carolina 29808

WSRC-TR--93-083

DE93 009870

Other Authors:

J. E. Wear, Jr.

(WSRC)

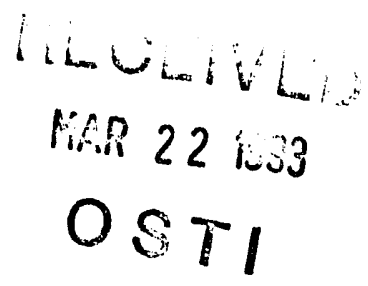

A paper proposed for Publication

at/in the Dissertation submitted to Wake Forest University

Winston-Salem, NC

$05 / 93$

This paper was prepared in connection with work done under Contract No. DE-AC09-89SR18035 with the U. S. Department of Energy. By acceptance of this paper, the publisher and/or recipient acknowledges the U. S. Government's right to retain a nonexclusive, royalty-free license in and to any copyright covering this paper, along with the right to reproduce and to authorize others to reproduce all or part of the capurighted paper. 


\section{DISCLAIMER}

This report was prepared as an account of work sponsored by an agency of the United States Government. Neither the United States Government nor any agency thereof, nor any of their employees, makes any warranty, express or implied, or assumes any legal liability or responsibility for the accuracy, completeness, or usefulness of any information, apparatus, product, or process disclosed, or represents that its use would not infringe privately owned rights. Reference herein to any specific commercial product, process, or service by trade name, trademark, manufacturer, or otherwise does not necessarily constitute or imply its endorsement, recommendation, or favoring by the United States Government or any agency thereof. The views and opinions of authors expressed herein do not necessarily state or reflect those of the United States Government or any agency thereof.

This report has been reproduced directly from the best available copy.

Available to DOE and DOE contractors from the Office of Scientific and Technical Information, P.O. Box 62, Oak Ridge, TN 37831; prices available from (615) 576-8401, FTS 626-8401.

Available to the public from the National Technical Information Service, U.S. Department of Commerce, 5285 Port Royal Rd., Springfield, VA 22161. 
Environmental Diagnostic Analysis of Ground Water Bacteria and Their Involvement in Utilization of Aromatic Compounds

by

John Edmund Wear, Jr.

A dissertation submitted to the Graduate Faculty of

Wake Forest University

in partial fulfillment of the requirements

for the degree of

DOCTOR OF PHILOSOPHY

in the Department of Biology

May, 1993

Winston-Salem, North Carolina

Approved by:

Terry C. Hazen, Ph.D., Laboratory Advisor

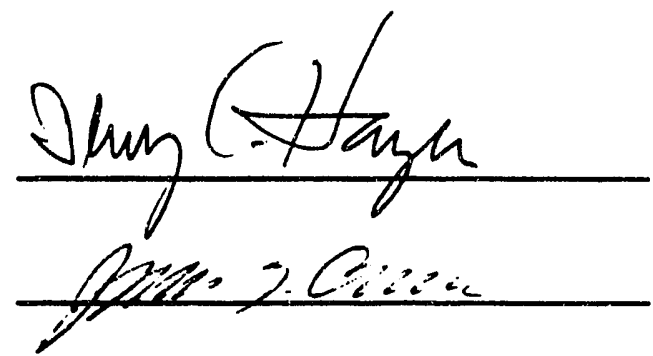

James F. Curran, Ph.D., Academic Advisor

Examining Committee:

Stephen H. Richardson, Ph.D., Chairman

Ronald V. Dimock, Ph.D.

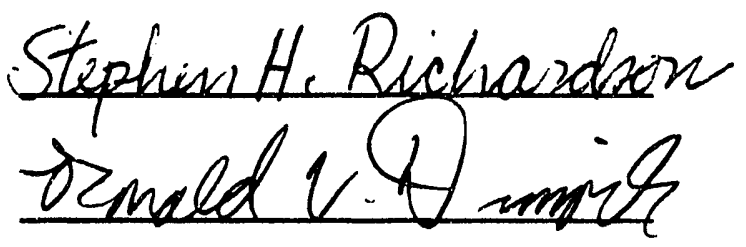

Robert A. Browne, Ph.D.

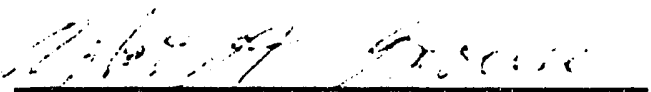


This dissertation is dedicated to:

my two children,

John and Elizabeth 


\section{Acknowledgments}

I can not express the gratitude I have for the excellent educational experience that I have had working at the Savannah River Technology Center under the direction of Dr. Terry Hazen. His thoughtful guidance and fatherly direction have been greatly appreciated. I have learned greatly from this prolific scientist. His expectations of excellence are reflected in the pride I have in my research accomplishments.

I would also like to thank Dr. James Curran my academic advisor and close friend. I am deeply in his debt. He provided laboratory space and supplies during the time I was at Wake Forest. He has given freely of his time and his advice has been invaluable.

Many thanks are due my fine committee: Dr. Steve Richardson, Dr. Ronald Dimock, and Dr. Robert Browne. I sincerely appreciate their invaluable advice and the time and interest they gave to my project. I am proud to have had all of them on my advisory committee.

I would like to thank all the people I have worked with at SRTC for making my association here a memorable one. I will always cherish the memories of the good friends I made here. I would like to thank the following people for their help and friendship. Dr. Carl Fliermans has graciously given constructive criticism and helpful ideas. Marilyn Franck has been a dedicated friend. She has given me enthusiastic help and support and has been a true inspiration. Pam McKenzie has given cheerful friendship and assistance. Dr. Joel Dougherty provided many helpful suggestions and ideas. Dr. Michael Enzien gave his time freely in support and assistance. I would like to thank Amy Phillips and Heather Findley for all of their help. James Napier, William Blackwell, Steve Riley, Chuck Betivas, Willy Fulmer, Larry Harrelson, Aubrey Carroll, and Johnny 
Simmons have provided greatly appreciated assistance. I would also like to thank Deb Moore-Shedrow, Dawn Kaback, Brian Looney, Carol Eddy, Ralph Nichols, Christopher Berry, and Deborah Eubanks for their help and assistance.

Several organizations contributed financial and logistical support. I am indebted to the Westinghouse Savannah River Company for providing me with excellent field and laboratory equipment, laboratory facilities, office space and support. The Savannah River Technology Center work was performed under contract number DE-AC09-89SR18035 between the U. S. Department of Energy and Westinghouse Savannah River Company. Dr. Hazen's research support is allocated from the Office of Technology Development's Integrated Demonstration Program. This publication is based on work performed in the Laboratory Graduate Participation Program under contract number DE-AC05760R00033 between the U.S. Department of Energy and Oak Ridge Associated Universities. Additional funding for this research was provided by Sigma Xi.

I wish to thank my entire family for their continued encouragement throughout my academic career. They have been a constant source of inspiration and guidance. My mother, Susie Hester Wear, has always encouraged me to be creative. My father, Dr. John Wear, has instilled in me a love of life sciences, nature and the outdoors. I would also like to thank Charles and Jean Rufty for their understanding and help during this endeavor. I would like to thank my wife, Lisa Rufty Wear, and my children, John and Elizabeth, for their love and understanding throughout this work. Their faith has given me strength. Through their sacrifices this endeavor has been possible. 


\section{TABLE OF CONTENTS}

ACKNOWLEDGMENTS iii

LIST OF TABLES viii

LIST OF FIGURES xiv

ABSTRACT $\quad$ xvi

INTRODUCTION

Ground water and ground water contamination. 1

Mechanisms of genetic adaptation. $\quad 8$

Carbon sources in ground water environments. 11

$\begin{array}{ll}\text { Objectives. } & 14\end{array}$

MATERIALS AND METHODS $\quad 15$

$\begin{array}{ll}\text { Sample sites. } & 15\end{array}$

Sampling groun!'water. $\quad 16$

Aromatic compounds used in this study. $\quad 16$

$\begin{array}{ll}\text { Aromatic utilization. } & 17\end{array}$

$\begin{array}{ll}\text { Toluene enrichment. } & 17\end{array}$

Lysis of bacterial cells for PCR amplification. $\quad 18$

PCR amplification of the catechol dioxygenase

$\begin{array}{ll}\text { gene. } & 18\end{array}$

Testing groundwater samples for chlorinated

$\begin{array}{ll}\text { organics. } & 19\end{array}$

Direct counts of groundwater bacteria. $\quad 20$

$\begin{array}{ll}\text { Plate counts. } & 20\end{array}$

Percentage of active cells. 21 
Biolog-MPN quantification of sole carbon source utilization. $\quad 21$

Data Analysis. $\quad 22$

$\begin{array}{ll}\text { RESULTS } & 24\end{array}$

Density of aromatic utilizers. $\quad 24$

Carbon sources utilized by ground water bacteria. 24

Direct counts and heterotrophic viable counts. 25

$\begin{array}{ll}\text { Percentage of active cells. } & 27\end{array}$

Detection of the XylE gene. 27

Physical and chemical parameters. 27

Dissolved oxygen. $\quad 28$

Oxidation-reduction potential. 29

Ground water $\mathrm{pH} . \quad 30$

$\begin{array}{ll}\text { Temperature. } & 30\end{array}$

Conductivity. $\quad 31$

Salinity. $\quad 31$

Trichloroethylene. $\quad 32$

$\begin{array}{ll}\text { DISCUSSION } & 33\end{array}$

Utilization of recalcitrant aromatic compounds in the subsurface. 33

Interactions between bacteria and $\begin{array}{ll}\text { contaminants. } & 35\end{array}$

Types of bacteria in Savannah River Site aquifers.

Role of the XylE gene in the utilization of aromatic compounds in groundwater 


$$
\text { environments. }
$$

Groundwater versus sediment sampling.

Bacterial density and diversity in

$$
\text { ground water. }
$$

The percentage of active cells in different groundwater environments.

CONCLUSIONS

LITERATURE CITED $\quad 46$

$\begin{array}{ll}\text { TABLES } & 64\end{array}$

$\begin{array}{ll}\text { FIGURES } & 78\end{array}$

$\begin{array}{ll}\text { APPENDICES } & 126\end{array}$ 


\section{LIST OF TABLES}

Table 1. Screened interval for groundwater wells.

Table 2. Sole carbon sources in Biolog GN microtiter

plates.

Table 3. Utilization of aromatic compounds by

groundwater microorganisms.

Table 4. Percentage of isolates utilizing carboxylic acids.

Table 5. Percentage of isolates utilizing carbohydrates.

Table 6. Percentage of isolates utilizing amino acids.

Table 7. Physical and chemical parameters for groundwater wells.

Table 8. Aromatic compounds utilized by Pseudomonas putida mt-2.

Table 9. Biolog sole carbon sources utilized by

Pseudomonas putida mt-2.

Table 10. Average relative compositions of carbohydrates

for humic acid, fulvic acid, and humin.

Table 11. Carbohydrates giving greatest density in the pristine wells.

Table 12. API-NFT results and gram stain reaction from three MSB cluster wells.

Table 13. API-NFT results and gram stain reaction for isolates from PTYG and 1\% PTYG media. 


\section{APPENDIX A.}

Table A-1. Analysis of ground water temperature by well and time.

Table A-2. Analysis of ground water temperature by well.

Table A-3. Analysis of ground water dissolved

oxygen by site and time.

Table A-4. Analysis of ground water dissolved oxygen by site.

Table A-5. Analysis of ground water dissolved oxygen by

well and time.

Table A-6. Analysis of ground water dissolved oxygen by well.

Table A-7. Analysis of ground water oxidation-reduction

potential by site and time.

Table A-8. Analysis of ground water oxidation-reduction

$$
\text { potential by site. }
$$

Table A-9. Analysis of ground water oxidation-reduction

potential by well and time.

Table A-10. Analysis of ground water oxidation-reduction

potential by well.

Table A-11. Analysis of ground water $\mathrm{pH}$ by site

and time.

Table A-12. Analysis of ground water $\mathrm{pH}$

by site.

Table A-13. Analysis of ground water $\mathrm{pH}$ by well and time.

Table A-14. Analysis of ground water $\mathrm{pH}$ by well.

Table A-15. Analysis of ground water conductivity

by well and time. 
Table A-16. Analysis of ground water conductivity by well.

Table A-17. Analysis of ground water acridine

orange direct counts by site and time.

Table A-18. Analysis of ground water acridine orange

direct counts by site.

Table A-19. Analysis of ground water acridine

orange direct counts by well and time.

Table A-20. Analysis of ground water acridine orange

direct counts by well.

Table A-21. Analysis of ground water hetero-

trophic viable counts on $1 \%$ PTYG agar by site

and time.

Table A-22. Analysis of ground water heterotrophic viable

counts on $1 \%$ PTYG agar by site.

Table A-23. Analysis of ground water hetero-

trophic viable counts on $1 \%$ PTYG agar by well

and time.

Table A-24. Analysis of ground water heterotrophic viable

counts on 1\% PTYG agar by well.

Table A-25. Analysis of ground water hetero-

trophic viable counts on PTYG agar by site

and time.

Table A-26. Analysis of ground water groundwater viable counts on

PTYG agar by site.

Table A-27. Analysis of ground water hetero-

trophic viable counts on PTYG agar by well 
and time.

Table A-28. Analysis of ground water heterotrophic viable counts on PTYG agar by well.

Table A-29. Anaiysis of percentage of active cells (as measured by acridine orange) by site and time.

Table A-30. Analysis of percentage of active cells

(as measured by acridine orange) by site.

Tahle A-31. Analysis of percentage of active cells (as measured by acridine orange) by well and time.

Table A-32. Analysis of percentage of active cells (as measured by acridine orange) by well.

Table A-33. Comparison of viable counts densities on PTYG and $1 \%$ PTYG agar.

Table A-34. Comparison of densities of carbohydrates, carboxylic acid, and amino acid utilizers.

Table A-35. Comparison of densities of amino acid utilizers between wells.

Table A-36. Comparison of densities of carbohydrate utilizers between wells.

Table A-37. Comparison of densities of carboxylic acid utilizers between wells.

APPENDIX B.

Table B-1. Correlation matrix for all wells.

Table B-2. Correlation matrix of the P28 site.

Table B-3. Correlation matrix of the P29 site.

Table B-4. Correlation matrix of the MSB site. 
Table B-5. Correlation matrix of aromatic sole carbon source utilization.

Table B-6. Correlation matrix of carbohydrate sole carbon source utilization.

Table B-7. Correlation matrix of polymer sole carbon source utilization.

Table B-8. Correlation matrix of carboxylic acid sole carbon source utilization.

Table B-9. Correlation matrix of amino acid sole carbon source utilization.

Table B-10. Correlation matrix of phosphorylated compound sole carbon source utilization.

Table B-11. Correlation matrix of ester sole carbon source utilization.

Table B-12. Correlation matrix of brominated sole carbon source utilization.

Table B-13. Correlation matrix of amine sole carbon source utilization.

Table B-14. Correlation matrix of amide sole carbon source utilization.

APPENDIX C.

Table C-1. Percentage of isolates utilizing alcohols, amides, amines, and aromatics.

Table C-2. Percentage of isolates utilizing brominated

chemicals, esters, phosphorylated compounds, and polymers. 
Table C-3. Number of different compounds utilized by groundwater bacteria in each well.

APPENDIX D.

Table D-1. Most probable number of bacteria capable of utilizing p-coumarate as a sole carbon source.

Table D-2. Most probable number of bacteria capable of utilizing ferulate as a sole carbon source.

Table D-3. Most probable number of bacteria capable of utilizing isovanillate as a sole carbon source.

Table D-4. Most probable number of bacteria capable of utilizing salicylate as a sole carbon source.

Table D-5. Most probable number of bacteria capable of utilizing phenol as a sole carbon source.

Table D-6. Most probable number of bacteria capable of utilizing m-toluate as a sole carbon source.

APPENDIX E.

Table E. Minimal media used in this study for testing the utilization of aromatic compounds. 


\section{LIST OF FIGURES}

Figure 1. Known substrates for TOL plasmid coded enzymes.

Figure 2. Proposed type structure of humic acid.

Figure 3. Proposed type structure of lignin.

Figure 4. Selected breakdown products resulting from oxidation of lignin and humic acid.

Figure 5. Map of South Carolina showing location of the

Savannah River Site.

Figure 6. Map of Savannah River Site showing location

of well sites and microbial ecology laboratory.

Figure 7. Geological crossection of the P28 site showing the formations sampled.

Figure 8. Geological crossection of the P29 site showing the formations sampled.

Figure 9. Aromatic compounds used in this study.

Figure 10. Utilization of aromatic compounds by bacteria from the P28 and P29 sites.

Figure 11. Mean acridine orange direct counts.

Figure 12. Mean heterotrophic plate counts on 1\% PTYG.

Figure 13. Mean heterotrophic plate counts on PTYG.

Figure 14. Mean percentage of active cells as measured

by acridine orange.

Figure 15. Mean ground water dissolved oxygen.

Figure 16. Mean ground water oxidation-reduction 
potential.

Figure 17. Mean ground water $\mathrm{pH}$.

Figure 18. Utilization of aromatic compounds by bacteria in the DCB7 well.

Figure 19. Mean ground water temperature.

Figure 20. Mean ground water conductivity.

Figure 21. Mean ground water trichloroethylene contamination at the MSB site.

Figure 22. Utilization of aromatic compounds by bacteria in the MSB wells.

Figure 23. Mean heterotrophic plate counts on low nutrient (1\% PTYG) and high nutrient (PTYG) media.

Figure 24. Mean bacterial densities as determined by acridine orange direct counts compared with heterotrophic plate counts on 1\% PTYG media. 


\begin{abstract}
John Edmund Wear, Jr.

Environmental Diagnostic Analysis of Ground Water Bacteria and their Involvement in Utilization of Aromatic Compounds
\end{abstract}

Fissertation under the direction of Terry C. Hazen, Ph.D., Adjunct Professor of Biology, Wake Forest University and Principal Scientist, Savannah River Technology Center.

The objective of this study was to examine the hypothesis that select functional groups of bacteria from pristine sites have an innate ability to degrade synthetic aromatics that often contaminate groundwater environments, due to exposure to naturally occurring recalcitrant aromatics in their environment.

Ground water was pumped at monthly intervals from twelve wells at four different sites. Two of these sites could be considered pristine. The other two sites were contaminated, one with trichloroethylene, the other with polyaromatic hydrocarbons and possible sulfur compounds. The bacteria in shallower wells tended to have both the greatest direct counts and heterotrophic viable counts. Acridine orange direct count differences between any of the wells were less than one order of magnitude. In contrast, viable counts had several orders of magnitude difference between wells. This illustrates that there are great variations in physiological states and metabolic needs of bacteria in these different aquifers. All but one of the wells studied demonstrated higher counts on low nutrient media than high nutrient media, suggesting the oligotrophic nature of these groundwater environments.

This study demonstrates that subsurface microbial communities are capable of utilizing lignin and humic acid breakdown products. Utilizers of these compounds were 
found to be present in most all the wells tested. Even the deepest aquifer tested had utilizers present for all six of the aromatics tested. Highest counts for the aromatics tested were observed with the naturally occurring breakdown products of either lignin or humic acid. Carboxylic acids were found to be an important sole carbon source for groundwater bacteria possibly explained by the fact that they are produced by the oxidative cleavage of aromatic ring structures. The carbohydrate sole carbon sources that demonstrated the greatest densities were ones commonly associated with humics. This study indicates that utilization of naturally occurring aromatic compounds in the subsurface is an important nutritional source for groundwater bacteria. In addition, it suggests that adaptation to naturally occurring recalcitrant substrates is the origin of degradative pathways for xenobiotic compounds with anaiogous structure. This work has important implications for in situ bioremediation as a method of environmental cleanup. 


\section{INTRODUCTION}

Ground water and ground water contamination. Potable ground water is vital to everyone. Ground water makes up over $95 \%$ of the world's freshwater reserves and is the main source of drinking water for a large percentage of the world's people. Nearly half of the population of the United States uses ground water from wells or springs as their primary source of drinking water (Bouwer, 1984). Thirty-six percent of the municipal public drinking water supply comes from ground water and seventy-five percent of major U. S. cities depend on ground water as their major water source (Pye and Patrick, 1983).

As a result of various human activities, particularly those involving disposal of chemical waste to the land, the quality of ground water is becoming increasingly threatened. During this century there has been a phenomenal expansion of the chemical industry. Due to this expansion there has been an increase in hazardous waste production. Total annual world production of synthetic organic chemicals is over 300 million tons. In addition, more than 1000 new compounds are marketed each year (Fewson, 1988). It was estimated that over 57 million metric tons of hazardous industrial waste were produced in the US during 1980 alone (Keswick, 1984). For these reasons, pollution of ground water due to hazardous waste is becoming a very serious problem. According to J. H. Lehr of the Association of Ground water Scientists and Engineers in Worthington, Ohio, more than 10 million Americans probably now use tap water with contaminant levels that exceed EPA standards (Knox, 1988). Each year our total withdrawals and our dependency on ground water increase, thus amplifying the impact that pollution has upon us. Industrial waste landfills are the most common source of serious ground water contamination because of their potential for leaching a wide variety of hazardous substances into underlying ground water (Keswick, 1984). 
One of the best known cases of industrial waste landfill pollution is the Love Canal Landfill in Niagara Falls, New York. Hooker Chemical Co. disposed of more than 43,000 tons of waste from 1942 to 1952 containing many hazardous chemicals. The chemicals disposed of included dioxin, hexachlorobenzene, tetrachloroethylene, chloroform, dichloroethane, benzene, hexachloride, trichloroethylene, toluene, and phenol. These substances have migrated from the landfill to other areas, and have affected both ground and surface waters. The cost to clean up this site was estimated at 45 million dollars (Keswick, 1984). The Superfund bill was passed by Congress in 1980 to assist in the cleanup of sites like this one, the greater portion of the money coming from industry. Originally the Superfund was to raise four billion dollars to be used in the clean up of hazardous waste. This amount has been increased substantially since. A 1983 report by the Office of Technology Assessment (OTA) estimated that 10,000 sites or more may require cleanup by Superfund (Goldsmith and Hildyard, 1988).

Conventional methods for cleaning up toxic waste polluted sites include air stripping, charcoal filtration and incineration. These methods tend to be expensive and essentially move the pollutant from one part of the environment to another. Air stripping volatilizes toxic waste, thus releasing them into the atmosphere. Charcoal filtration can efficiently remove toxic waste but only captures the toxic waste by adsorption and does not destroy it. These wastes can potentially leach out of the charcoal once the charcoal has been disposed of in the landfill. High temperature incineration can, if properly operated, have very good destruction efficiencies. But, if not operated correctly, incineration can result in the release of wastes that were not destroyed, or in the formation and release of new products of incomplete combustion (Goldsmith and Hildyard, 1988).

There is a tremendous potential for utilizing subsurface microorganisms to cleanup toxic waste contaminated sites. Many contaminants in solution in the ground water, as well as vapors in the vadose (unsaturated) zone, can be completely degraded and possibly 
utilized or transformed into new compounds by naturally occurring indigenous microbial populations. In fact, the complete degradation of organic molecules in water and soils is almost always a consequence of microbial activity (Alexander, 1980). This biodegradation can often result in the transformation of hazardous organic chemicals into innocuous products.

A term used to describe the utilization of microorganisms to clean up contaminated sites by biodegradation of the contaminants is bioremediation. For bioremediation to be an effective method of cleaning up toxic waste sites, some assistance must be given the microorganisms so that they can carry out biodegradation more efficiently. According to John T. Wilson of the EPA's Kerr Laboratories, without human intervention microorganisms typically degrade only about $1 \%$ of the hydrocarbon pollution flowing past them (Knox, 1988). There are a number of ways that the subsurface environment can be modified to increase the rates at which biodegradation will occur. Since oxygen is frequently one of the major limiting factors, dissolved oxygen can be increased by injecting hydrogen peroxide into the subsurface through injection wells. Other limiting nutrients like nitrogen and phosphorus can also be injected. The amounts of these nutrients are determined by the specific environmental conditions and the requirements of the microorganisms that have the potential to break down the pollutant.

Altering the subsurface environment in order to stimulate the indigenous microorganisms to degrade xenobiotic contaminants is called in situ bioremediation. In situ bioremediation of aquifers is a promising method for cleaning up contaminated sites in a cost effective manner. An important aspect of in situ bioremediation is that the physical removal of contaminated soils is not necessary, which significantly reduces cost and public health risks (Wilson et al., 1986). There are some problems associated with in situ bioremediation. Upon injection of nutrients, so much bacterial biomass may be 
produced that the flow of water in that vicinity is restricted. Another potential problem is that compounds that are even more toxic than the contaminant itself may be produced. For example, under anaerobic conditions trichloroethylene may be transformed into vinyl chloride a much more toxic compound (Wilson $\varepsilon$ id Wilson, 1985). A fundamental problem with in situ bioremediation is the inability of microorganisms to break down specific contaminants due to the structure of the contaminant. Recalcitrance, or the ability of a substance to remain in a particular environment in an unchanged form, can be increased as a result of polymerization and branching, and the presence of chlorine atoms on the molecule. The greater the number of attached chlorine atoms per molecule relative to the total number of carbon atoms, the more difficult it is for a compound to be broken down (Alexander, 1965; Fewson, 1988).

Cleavage of the carbon-halogen bond is endergonic and thus requires a substantial energy input. The energetics of the degradation of extensively halogenated carbon compounds is such that there is little prospect for microorganisms to adapt to many of these compounds as growth substrates (Atlas and Bartha, 1987). Other factors may also affect the biodegradation of specific pollutants. The pollutants may be present in mixtures that are incompatible for effective degradation or they may be in too low or too high a concentration. Genetic factors may also be involved, for instance, the inducer for a pathway may not be present, or the pathway may be blocked by inhibitors (Lindow et al., 1989).

In addition to the recalcitrance of certain contaminants, other factors can affect in situ bioremediation. Several environmental factors are known to influence the capacity of the indigenous microbial population to degrade contaminants. These factors include dissolved oxygen levels, $\mathrm{pH}$, temperature, oxidation-reduction potential, availability of mineral nutrients, salinity, concentration of specific pollutants, and the nutritional quality of dissolved organic carbon in the ground water (Wilson et al., 1986). In some situations 
the pollutant is broken down or modified even though it is not utilized for growth by the microorganism. This process, called co-metabolism, occurs while the microorganism is metabolizing another substrate (Horvath, 1972). Co-metabolism may prove useful as a means of utilizing bacteria to degrade recalcitrant halogenated organics, as, for example, the breakdown of trichloroethylene (TCE) by Pseudomonas putida harboring the TOL plasinid (Nelson et al., 1988). While these strains do not utilize TCE, it is broken down by enzymes that are produced by these microorganisms for the metabolism of another substrate.

Probably the best way to study the potential for in situ bioremediation is by examining the sediments, but our technology at the present time does not enable us to do this in a cost effective way. Also, since samples of subsurface sediments are taken at only one point and the sampling process is destructive, the precise point at which the sample was taken cannot be sampled again, although nearby sites could be sampled.

An alternative to sampling sediments is to study the ground water. Water sampling has several advantages over sediment sampling. Ground water can be sampled at different intervals, therefore, subsurface microorganisms can be studied as the parameters of interest change with time. These variations may be due, for instance, to precipitation and seasonal changes affecting the rate of recharge of the aquifer and causing the levels of other parameters such as pollutant concentration to fluctuate. A major disadvantage of ground water sampling is that under many conditions the ground water may not be indicative of the microbial communities actually associated with the surrounding sediments (Hazen et al., 1991; Kolbel-Boelke et al., 1988). It has been clearly shown that the microbial flora of sediment and ground water environments decrease in similarity with increasing depth and as conditions go from eutrophic to oligotrophic (Hazen et al., 1991). Thus, the value of using ground water methods is greatest in near-surface environments which are usually where contaminants are found. 
The importance of subsurface microorganisms in controlling the quality of ground water has recently become apparent (Wilson and McNabb, 1983). Yet, relatively little is known about the microbiology of ground water (McNabb and Mallard, 1984). Early microbiological studies concluded that the sediments below the root zone were essentially devoid of life (Waksman, 1916). However, these early studies depended solely on the culturability of the microorganisms, and the high nutrient culture methods employed were subsequently demonstrated to be of limited value in determining the bacterial densities in the subsurface environment. These erroneous conclusions delayed progress in the study of the microorganisms in subsurface habitats for many years later. For example, a comprehensive search of the literature by United States Environmental Protection Agency scientists in the early 1970 's revealed virtually no information on the indigenous microflora of common drinking-water aquifers between a few meters to several hundred meters deep (Ghiorse and Wilson, 1988).

Not only is it now clear that microbial communities exist in deep subsurface environments but it has also been demonstrated that these microorganisms are abundant. For example, Wilson et al. (1983b) found that the numbers of microorganisms in a shallow water-table aquifer were surprisingly high and did not appear to decrease dramatically with increasing depth. Indeed, researchers associated with the Department of Energy's Deep Probe project demonstrated that microbial life was abundant at far greater depths (greater than $300 \mathrm{~m}$ ) than ever before aseptically sampled (Fredrickson and Hicks, 1987).

The density of heterotrophic microorganisms is often limited by the concentration of metabolizable carbon (Poindexter, 1981; Atlas and Bartha, 1987). For microorganisms to be abundant in deep subsurface habitats, carbon sources must be available that would support growth. Subsurface areas not associated with petroleum, peat, or coal deposits usually have low organic carbon concentrations and, hence, can be considered 
oligotrophic (Ghiorse and Balkwill, 1983; White et al., 1983). The populations of subsurface bacteria found in these areas most closely resemble populations seen in oligotrophic aquatic environments (Kuznetsov et al., 1979). Since primary production in the subsirface is low, bacterial cells must utilize carbon sources leached from the surface or deposited in the adjacent geological strata. Microbes in the subsurface environment are forced to exist "on the stuff that no one bothered to eat" (Wilson and McNabb, 1983).

Due to the low organic carbon, competition is likely to be extreme, with selection favoring microorganisms that can utilize carbon sources that might otherwise not be exploited (Jiménez, 1989). Selection, under these conditions, might result in microorganisms in the subsurface environment with unusual pathways for biotransformations that are very different from those of microbes found at the surface (Wilson and McNabb, 1983; McCarty et al., 1984).

A relatively new source of nutrients in many aquifers is organic contamination. Many microorganisms have adapted to the pollution that has entered their environment and, in fact, can utilize it as a source of energy and organic carbon. Because of the low levels of metabolizable carbon in these environments, the addition of hydrocarbon pollution enables many of these microorganisms to flourish (Harvey et al., 1984; Knox, 1988).

In some situations these organic contaminants are not readily utilized as carbon sources but instead remain in the environment for extremely long times. One reason is that many of these compounds are xenobiotics, these are compounds that are man-made and therefore have chemical structures to which these microorganisms have not been exposed (Fewson, 1988). Since the microorganisms have not been exposed to these chemicals there has been no selection for organisms able to utilize these potential organic carbon sources. Therefore these compounds are often resistant to biodegradation. 


\section{Mechanisms of genetic adaptetion.}

A number of mechanisms have been suggested that might account for genetic adaptation of microorganisms to xenobiotic compounds. One possible way a catalytic pathway may arise is for a mutation to occur that enables a bacterium to utilize a substrate that it could not otherwise utilize or would not utilize efficiently. A mechanism that would allow this to occur (without loss of the ability to utilize the original substrate) would be gene duplication followed by sequence divergence. The original gene might remain functional while the duplicated gene is free to undergo mutational events that might increase its catabolic specificity dirr other substrates (Clarke, 1984). For example, chemostat cultures of Escherichia coli that were naintained on low concentrations of lactose, have been shown to uniergo duplication of the lac genes and as a result experience more rapid growth and a greater capability to store food reserves than those bacteria with single copies (Horiuchi et al., 1962). There have been similar observations with ot'ier species (Inderlied and Mortlock, 1977; Rigby et al., 1974).

A complication with genetic adaptation is that an accompanying regulatory mutation may need to occur. For example, an existing catalytic pathway might enable the bacteria to break down the contaminant but a regulatory mutation needs to occur in order that the pathway be induced (Mortlock, 1981). Another possibility is that a mutation may alter the specificity of the first enzyme in a pathway that has already undergone a constitutive mlitation, followed later by a regulatory mutation that induces the pathway only when the new substrate is present (Hall, 1984). Both of these events might occur following gene duplication.

Transposons may pley an important role in adaptation of bacteria to xenobiotics. Transposons carry genes that allow the transposon to move from one DNA replicon to another, for example, from chromosome to conjugative plasmid (Beringer and Hirsch, 1984). Some transposons are known to contain active catabolic genes (Cornelis et al., 
1978), and there is evidence that transposons are transferred widely. Transposon TN1, which contains a gene for ampicillin resistance, has been observed all over the world in a number of different genera (Heffron et al., 1975).

Once a pathway exists for the utilization of a novel substrate, mechanisms such as transformation, transduction and conjugation could allow the rapid dissemination of those genes throughout bacterial populations. Horizontal transfer by conjugative plasmids may play an important part in the formation of novel pathways. Studies have shown a higher frequency of plasmids in bacterial isolates from environments where nutritional or pollution stress exists (Wickham and Atlas, 1988; Fredrickson et al., 1988). A number of plasmids have been found that enable their host to degrade compounds that would otherwise remain in the environment as pollutants. Many bacterial genes for xenobiotic degradation have originated from strains isolated from contaminated waste sites and these genes are often found on plasmids (Lindow et al., 1989).

Plasmids are autonomously replicating covalently closed, circular extrachromosomal DNA. They can be inherited without being linked to the chromosome (Crosa and Falkow, 1981; Hardy, 1986). They are not essential for survival but they may encode genetic determinants that permit the host to survive better in an adverse environment or to compete better with others occupying the same ecological niche (Crosa and Falkow, 1981). Plasmids could assist genetic adaptation to xenobiotics because there is not only a greater potential for plasmids to transfer to other microorganisms but also for plasmids to recombine with each other to produce new arrangements of genes (Beringer and Hirsch, 1984). Studies have shown that the evolution of an interacting microbial community may be more important in the evolution of a novel pathway than a series of evolutionary events occurring within one organism (Slater, 1984). Several studies using chemostats have indicated that it is possible to observe gene transfer and the formation of novel pathways using mixed cultures of bacteria and mobilizable plasmids 
(Kellogg et al., 1981; Knackmuss, 1981, Slater et al., 1984). Evidence exists that relicons such as plasmids can be disseminated widely, even to other genera. Plasmid RP1 has been identified as appearing unchanged in 17 different bacterial genera (Slater, 1984).

Almost all of the plasmids characterized to date that have genes for xenobiotic catabolism have been from gram negative bacteria, predominantly Pseudomonas (Lindow et al., 1989). The most studied and best understood catabolic plasmid is the TOL plasmid. The archetype TOL plasmid was first described in 1974 (Williams and Murray, 1974). This plasmid codes for enzyme pathways that enable the microorganism harboring it to degrade toluene, $m$-xylene, $\mathrm{p}$-xylene and other similar organic substances (Figure 1). TOL plasmids are usually found in Pseudomonas species (Burlage et al., 1989). The toluene utilizing genes of the TOL plasmid may not be confined to plasmids, but may also be located on chromosomes. Genes that are almost identical to those on the TOL plasmid have been detected in the chromosome of an isolate of Pseudomonas putida that was able to live on toluene as a sole carbon source (Sinclair et al., 1987). The host range of the TOL plasmid possibly includes other genera. For example, a TOL-like plasmid has been described in Alcaligenes eutrophus (Hughes et al., 1984).

The ubiquity of the TOL plasmid has been examined using standard methods of enrichment and isolation. Williams and Worsey (1976) isolated thirteen bacteria from soil samples using selective enrichment on m-toluate minimal medium. All thirteen carried plasmids that were similar to the archetype TOL plasmid although these plasmids did show variations in their properties.

The TOL plasmid can dissociate into two or more separate plasmids that are capable of independent replication. Dissociation gives rise to a non-conjugative plasmid, which specifies the degradative pathway, and to a separate conjugative plasmid. The fragment of TOL which can be inserted into unrelated DNA molecules has a molecular weight of about $40 \times 10^{6}$ daltons. TOL plasmids can also dissociate to lose a fragment 
that has a molecular weight of about $30 \times 10^{6}$ daltons. This appears to involve recombination between directly repeated 1400 base pair sequences (Hardy, 1986).

Catabolic plasmids which appear to be related to the TOL plasmid include the NAH plasmid (Dunn and Gunsalus, 1973) which codes for naphthalene degradation, the OCT plasmid (Chakrabarty et al., 1973) which codes for n-octane degradation, the SAL plasmid which codes for salicylate degradation (Chakrabarty, 1972) and the CAM plasmid which codes for camphor degradation (Rheinwald et al., 1973). All of these plasmids were originally found in different strains of Pseudomonas putida.

\section{Carbon sources in ground water environments.}

Organic compounds in ground water consist mainly of recalcitrant humic and fulvic acids, tannins and lignins (Wallis et al., 1981). These recalcitrant substances and their breakdown products may be a major carbon and energy source for bacteria in sediments and ground water. Humic substances (Figure 2) are a major reservoir of organic carbon in aquifers (Aiken et al., 1985), and can consist of $21 \%$ to $66 \%$ of the total dissolved organic carbon (Thurman, 1985). Humic acid resists degradation by microorganisms as evidenced by the long residence times of this compound (Campbell et al., 1967). Radiocarbon dating has demonstrated humic compounds thousands of years old in some soil (Jenkinson and Rayner, 1977). The recalcitrance of humic molecules is due to their molecular weight and complex structure, both resulting from disorderly condensation and extensive co-polymerization and crosslinking (Stout et al., 1981).

There are at least two hypotheses to account for the origin of humic substances in ground water, one, that humic material originates in overlying soils and is leached from organic matter moving through the vadose zone and into recharge waters, and two, that humic substances are leached from kerogen in the sediment of the aquifer (Thurman, 
1985). In fact, kerogen has been described as the most common organic material on earth (Brownlow, 1979).

Lignin (Figure 3) is second only to cellulose as a reservoir of metabolically derived carbon in the biosphere (Zelkus, 1981). One function of lignin in plants is to impede microbial destruction of plant tissues, which might explain in part why it is the most recalcitrant natural product (Zelkus, 1981). In certain environments the recalcitrance of lignin can result in the formation of lignites and coals, the major forms of fossilized organic matter on earth (Zelkus, 1981). Among the reasons for the recalcitrance of lignin are that it is slowly metabolized because it is an insufficient energy source for microbial growth, its insolubility in water, and the inaccessibility to cleavage of its intermolecular bonds. It also appears that lignolytic microbes require oxygen, since lignin does not degrade in anaerobic environments (Zelkus, 1981). The breakdown of lignin is important in humic acid formation (Brownlow, 1979). Although lignin is resistant to degradation, there are known lignin-degrading fungi, actinomycetes, and bacteria (Crawford, 1981; Crawford and Crawford, 1984).

Because the concentration of organic carbon in ground water is commonly less than $1 \mathrm{mg}$ carbon per liter (Leenheer et al., 1974), it is difficult to isolate and characterize the breakdown products of these compounds, and for this reason there are relatively few studies of these substances in ground water (Thurman, 1985). Therefore, data are not available on naturally occurring aromatic breakdown products of lignin and humic acid in ground water.

The oxidation of both lignin and humic acid (Figure 4) results in a mixture of phenolic aldehydes and acids (Atlas and Bartha, 1987). Laboratory investigations indicate what some of these compounds might be. Lignin and humic acid must be broken down extracellularly before the chemical subunits enter the cell. For example, the whiterot fungi must break down lignin extracellularly to fragments small enough to diffuse to 
and enter the hyphae. Chen et al. (1982) identified nine aromatic acids produced during the degradation of lignin by the white-rot fungus Phanerochaete chrysosporium. These compounds included p-hydroxybenzoic acid, vanillic acid, isovanillic acid, veratric acid, dehydrovanillic acid, and 4-hydroxy-5-methoxypthalic acid. Crawford (1981) used gas chromatography and G.C.-mass spectrometry to identify several simple lignin derivatives, including p-hydroxybenzoic acid, vanillic acid, protocatechuic acid, pcoumaric acid, syringic acid, and ferulic acid, from cultures of the aerobic lignolytic actinomycete Streptomyces viridosporus. A study by Donnelly and Crawford (1988) demonstrated that p-coumarate was the dominant compound in culture supernatants of a species of Streptomyces.

Therefore, from these studies, it would appear that aromatic monomers should occur in ground water wherever lignin or humic acid is being broken down. If this is true then these aromatic compounds should be a source of metabolizable carbon for bacteria in subsurface environments. In addition, aromatic compounds with similar structures might be degraded as well. Prior evidence has demonstrated this possibility.

A study of microbes in shallow subsurface soil demonstrated that these microbes could degrade toluene (Wilson et al., 1983a). A study by Ventullo and Larson (1985) found that benzoic acid was rapidly mineralized in ground water. Ward (1985) demonstrated that benzoic acid was mineralized in both anaerobic and aerobic soils. Suflita and Miller (1985), using ground water aquifer microcosms, demonstrated that the microflora of ground water aquifers have the potential for degrading phenolic substrates. Phenol was metabolized in all the tested ground water habitats. Dobbins et al. (1987) demonstrated that there was great variation in mineralization potential of phenol between differing soil types and subsurface horizons. Federle (1988) demonstrated that phenol, benzoic acid and benzylamine (all monosubstituted aromatic compounds) were mineralized rapidly in two shallow $(20 \mathrm{~m})$ soil profiles. In addition, the variability in 
mineralization activity within a soil profile could exceed the mineralization activity between two quite different profiles. Hicks and by Fredrickson (1989) studied mineralization of acetate, phenol and 4-methoxybenzoic acid in deep subsurface sediments at SRS. They found that biodegradation of the labeled substrates did not appear to be related to depth and was often as high or higher in the lower strata as it was in the upper strata or in the surface soil. A number of other studies have isolated bacteria capable of utilizing the breakdown products of lignin and humic acid (Gonzalez et al., 1986; Ball et al., 1989).

Therefore, it would appear that utilization of aromatic compounds found naturally that are breakdown monomers of lignin and humic acid or other complex aromatic substances may allow microbes in the subsurface to genetically adapt to the utilization of xenobiotic aromatic compounds introduced into the environment.

Objectives. My hypothesis is that, due to exposure to naturally occurring recalcitrant aromatics in their environment, select functional groups of bacteria from pristine sites have an innate ability to degrade synthetic aromatics that often contaminate ground water environments. This study differs from previous studies that have examined this area in that naturally occurring breakdown monomers of lignin and humic acid were used and the indigenous bacteria capable of using these compounds were quantified. This hypothesis was tested in the following ways: First, by determining the density of select functional groups of bacteria responsible for the degradation of certain naturally occurring and synthetic aromatics in pristine and contaminated ground water environments. Second, by determining the innate ability of microbial communities from pristine and contaminated environments to degrade synthetic aromatic compounds. Third, by examining the ways in which abiotic factors might affect the density and catabolic potential of these microbes to degrade aromatics. 


\section{MATERIALS AND METHODS}

Sample sites. This research was conducted at the Department of Energy's Savannah River Site, a $768 \mathrm{~km}^{2}$ nuclear production facility, producing nuclear materials for national defense, medical applications and the space program. Located in the Upper Atlantic Coastal Plain, near Aiken, South Carolina (Figure 5), the site is operated by Westinghouse Savannah River Company for the United States Department of Energy. It was built in the early 1950's and has five different nuclear reactors, one of which is still functional. Therefore, it has all the processing wastes associated with these types of operations, including solvents, petroleum and coal pile leachates. Geologically, the surface at the site is composed of approximately $400 \mathrm{~m}$ of unconsolidated sands, clayey sands and sandy clays that overlie a basement of dense metamorphic rock, igneous intrusives, or consolidated sedimentary rock. For a cumplete geological description see Sargent and Fliermans (1989). Ground water was pumped at monthly intervals from twelve wells at four different sites: P28, P29, DCB, and MSB (Figure 6). The screened interval (well casing water intake holes) for these wells ranges from depths of $33.2 \mathrm{~m}$ to $210.3 \mathrm{~m}$ (Table 1). Two of the most common ground water contaminants at the Savannah River Site have been trichloroethylene and polyaromatic hydrocarbons.

Trichloroethylene was used in the past for used for degreasing target elements. The MSB site is associated with a leaky process sewer line that has released trichloroethylene into the surrounding soil and subsequently into the underlying ground water. This site has the highest trichloroethylene contamination of all four sites with a mean concentration of $41,100 \mathrm{ppb}$. Although the Savannah River Site has had a number of different nuclear reactors, energy is produced using coal. Therefore coal piles are present and the accompanying contamination by polyaromatic hydrocarbons. The DCB site is associated 
with coal piles and is contaminated with a heterogeneous mixture of trichloroethylene, polyaromatic hydrocarbons and possible sulfur compounds. The DCB site has a mean TCE concentration of $60 \mathrm{ppb}$. The P28 (Figure 7) and P29 (Figure 8) sites could be considered pristine. The direction of vertical flow in these wells is downward for the Congaree but upward for the formations sampled below the Congaree which in this study were the Pee Dee and Middendorf formations (Sargent and Fliermans, 1989). Two wells, P29TA and P28TA are wells bored and sampled for the Department of Energy's Deep Subsurface Microbiology Program (Fredrickson et al., 1987; Fredrickson et al., 1989; Fliermans and Balkwill, 1989). For a complete discussion of the Deep Subsurface Microbiology Program results see volume 7 of the Geomicrobiology Journal.

Sampling ground water. A portable generator supplied electrical power to the submersible pumps already in place at each well site. A Hydrolab surveyor model SVR2. SU sonde unit (Hydrolab Inc., Austin, TX) was connected to a valve at the surface. Since water in the well casing exchanges gases with the atmosphere and interacts with the well casing, it is not representative of the water in the aquifer. Therefore, the water was pumped from each well until the conductivity and $\mathrm{pH}$ of the water being purged stabilized (Lee and Jones, 1983; US EPA, 1987, Handbook 625/6-87/016), at which point a sterile 4 liter and $250 \mathrm{ml}$ Nalgene bottle was filled aseptically for bacterial analysis. A $30 \mathrm{ml}$ amber glass bottle with teflon septa also was filled for chemical determination using gas chromatography.

Aromatic compounds used in this study. The ability of the indigenous bacteria to utilize each of six aromatic compounds was quantified in this study (Figure 9). Ferulic acid, p-coumaric acid and isovanillic acid represent lignin and humic acid breakdown products (Chen et al., 1982; Crawford, 1981; Donnelly and Crawford, 1988). Salicylic acid is produced by plants and is an intermediate in the degradation of some polyaromatic 
compounds (Cerniglia, 1984). Salicylate (also known as 2-hydroxybenzoate) has been identified as an intermediate in the naphthalene degradation pathway and as an inducer of the nah operon carried on the NAH7 plasmid for the degradation of naphthalene (Schell, 1985). Phenol represents a class of ground water contaminants (MacRae, 1989). MToluic acid is a substrate utilized by Pseudomonas putida MT-2 which harbors the TOL plasmid and has been used as an enrichment medium for the isolation of TOL plasmids in a number of studies (Williams and Worsey, 1976).

Aromatic utilization. In order to quantify the number of bacteria capable of utilizing aromatic compounds, a most probable number method was used. The bacterial cells in ground water were concentrated by filtration. One hundred $\mathrm{ml}, 10 \mathrm{ml}$ and $1 \mathrm{ml}$ aliquots of ground water were taken from the $250 \mathrm{ml}$ sample flask and were filtered through $0.22 \mu \mathrm{m}$ pore size Nuclepore polycarbonate filters (Costar Corp., Cambridge, MA). Filters were then placed in tubes containing $7 \mathrm{ml}$ of modified Stanier's minimal media (Stanier et al., 1966) and $100 \mathrm{ppm}$ of the aromatic to be tested. Smaller volumes, $0.1 \mathrm{ml}$ and $0.01 \mathrm{ml}$, were dispensed directly into the tube without filtration. Five replicates were made for each volume. After three weeks of incubation at $25^{\circ} \mathrm{C} \mathrm{a} 600 \mathrm{ml}$ aliquot was removed and filtered using a $0.45 \mu \mathrm{m}$ Durapore filter (Millipore Corp., Bedford, MA) and examined for the disappearance of the aromatic substrate using a Gilford Response UV spectrophotometer (Ciba Corning Diagnostics Corp., Norwood, MA). (Note: Stanier's minimal media has been used in sole carbon source studies of aerobic Pseudomonads; Stanier et al., 1966). Preliminary experiments indicated that the greatest number of bacteria were observed when using the medium as specified by the author and with the addition of $100 \mathrm{ppm}$ of the aromatic carbon source.

Toluene enrichment. Ground water $(100 \mathrm{ml})$ was filtered through $0.22 \mu \mathrm{m}$ pore size Nuclepore polycarbonate filters (Costar Corp., Cambridge, MA) and the filters were placed in cotton stoppered tubes of Stanier's minimal media with no carbon source. The 
tubes were then placed in jars with an atmosphere saturated with toluene. Additional tubes containing Stanier's minimal media were inoculated with $1000 \mathrm{ppm}$ or $100 \mathrm{ppm}$ toluene and capped with a teflon septum.

Lysis of bacterial cells for PCR amplification. A $200 \mu \mathrm{l}$ volume of the Stanier's minimal medium enriched with one of the aromatics was placed in a sterile $0.5 \mathrm{ml}$ microfuge tube, centrifuged and washed once with sterile ultra-filtered water. Tubes were then placed in dry ice for 10 minutes, removed then heated to $50^{\circ} \mathrm{C}$ for 1 minute in a thermal cycler (DNA Thermal Cycler, Perkin-Elmer Corporation, Norwalk, CT). The freeze-thaw procedure was repeated six times. After every second freeze-thaw cycle, the tubes were vortexed for 15 seconds then centrifuged briefly to bring fluid to the bottom of the tube. After all six freeze thaw cycles were completed, the tubes were placed in the thermal cycler at $85^{\circ} \mathrm{C}$ for 5 minutes to inactivate nucleases. Tubes were then ready for the addition of the PCR mix (Bej et al., 1991).

PCR amplification of the catechol dioxygenase gene. The nucleotide sequences for the catechol dioxygenase gene from both the NAH and TOL plasmids have been reported (Harayama et al., 1987). By comparing both segments it was possible to determine highly conserved regions that may be suitable to use as oligonucleotide primers. Three positive strand primers and three negative strand primers were chosen and combinations of all possible pairs of these primers were tested. The pair of primers selected in this study were the pair that produced the greatest amount of amplicon using the model organism for this study (Pseudomonas putida mt-2 which harbors the TOL plasmid). These were 20-base oligomers specific for sites flanking the target sequence on the catechol dioxygenase gene. To determine that the amplicon produced was the correct sequence, a restriction digest was performed using several different restriction enzymes and the sizes of the fragments compared with known size standards (Sambrook et al., 1989). 
PCR amplification was performed using AmpliTaq DNA polymerase and a GeneAmp kit (Cetus Corp., Emeryville, CA) as described by Saiki et al. (1988). In order to determine suitable primers for amplification of the catechol 2,3 dioxygenase gene, regions in the gene were first chosen that were identical in both the NAH and TOL plasmids. These regions would be less likely to undergo mutation and therefore the chances of finding this sequence in the environment using PCR would be improved. A number of positive and negative strand primers were synthesized with sequences that were from these conserved sequences. Pairs of primers were then tested using the model bacterium, Pseudomonas putida mt-2 (which harbors the TOL plasmid). PCR primers were chosen using the following guidelines: a length of 18 to 28 bases, $50 \%$ to $60 \% \mathrm{G}+\mathrm{C}$ content, the calculated thermal melting points for the bases should be balanced, complementarity at the $3^{\prime}$ ends should be avoided, and there should be no (or little) internal homology capable of forming hairpin structures (Innes and Gelfand, 1990). The primer pair 5' GGG CCG TGT CTA TCT GAA GGC 3' and 5' GGT TAC CGG ACG GGT CGA AG 3' was chosen because it gave the highest yield of amplicon when PCR was performed on Pseudomonas putida $\mathrm{mt}-2$. The calculated $\mathrm{T}_{\mathrm{m}}$ for these two primers was $68^{\circ} \mathrm{C}$ and $66^{\circ} \mathrm{C}$, respectively. These primers were synthesized to these specifications and purified using polyacrylamide gel electrophoresis by Synthetic Genetics, San Diego, California. The protocol for PCR was $10 \mathrm{~min}$ at $95^{\circ} \mathrm{C}$ followed by 30 cycles of $1 \mathrm{~min}$ at $95^{\circ} \mathrm{C}, 1 \mathrm{~min}$ at $60^{\circ} \mathrm{C}$, and $1 \mathrm{~min}$ at $72^{\circ} \mathrm{C}$ then finally $3 \mathrm{~min}$ at $72^{\circ} \mathrm{C}$.

Testing ground water samples for chlorinated organics. Samples were taken in amber $(30 \mathrm{ml})$ glass bottles and sealed with teflon septa. Upon reaching the laboratory 10 $\mathrm{ml}$ aliquots of ground water were dispensed into $20 \mathrm{ml}$ serum vials with teflon-sealed crimp tops and refrigerated until ready to test using gas chromatography. Sealed samples were tested the day the sample was taken using a headspace sampling method. When volatile organics in water are allowed to come to equilibrium with the vapor head space, 
the concentration in the head space is proportional to the concentration in the water (Micure, 1981). Samples were processed using an automated head space gas sampling device (Model 1939.5A, Hewlett Packard, Avondale, PA) with a bath temperature of $75^{\circ} \mathrm{C}$. Trichloroethylene was analyzed using a Hewlett Packard 5890 gas chromatograph (Hewlett Packard, Avondale, PA) equipped with a 60m X $0.75 \mathrm{~mm} \mathrm{I.} \mathrm{D.} \mathrm{VOCOL}$ capillary column (Supelco, Bellefonte, PA) and an electron-capture detector (ECD). The following conditions were used: oven temperature, $32^{\circ} \mathrm{C}$ for $8 \mathrm{~min}$ then increased $4^{\circ} \mathrm{C} / \mathrm{min}$ until reaching $80^{\circ} \mathrm{C}$, then held at $80^{\circ} \mathrm{C}$ for 1 minute; injector temperature, $175^{\circ} \mathrm{C}$; and detector temperature $325^{\circ} \mathrm{C}$. The split ratio was set at $1: 1$. The carrier gas was $\mathrm{He}$ and the make-up gas was $\mathrm{N}_{2}$. Quantitative analyses were made for TCE by relating peak heights of samples to those of prepared standard curves.

Direct counts of ground water bacteria. Acridine orange direct counts were used to enumerate ground water bacteria. This is a method that is widely used and has been demonstrated to be one of the best methods available today for enumeration of bacteria in environmental samples (Daley, 1979). It is useful when enumerating the entire population of microorganisms but it does not distinguish between specific organisms or groups. Samples ( 4.4 liters) were concentrated to $10 \mathrm{ml}$ using continuous flow centrifugation. Ten $\mu$ l aliquots were applied to the eight wells of a toxoplasmosis slide (Cel-Line Associates Inc., N. J.) and heat fixed by placing the slide on a slide warmer at $50^{\circ} \mathrm{C}$ until dry. Slides were stained with acridine orange (Difco SpotTest \#3561-26-5) for 2 minutes, rinsed with filtered distilled water and bacterial numbers counted using a Zeiss epifluorescence microscope (Lopez de Victoria, 1989).

Plate counts. Two media were used for heterotrophic viable plate counts, PTYG and 1\% PTYG. PTYG agar contains the following ingredients per liter of distilled water: glucose, $10 \mathrm{~g}$; yeast extract, $10 \mathrm{~g}$; peptone, $5 \mathrm{~g}$; Trypticase, (Becton Dickinson Microbiology Systems, Cockeysville, MD), $5 \mathrm{~g} ; \mathrm{MgSO}_{4} \cdot 7 \mathrm{H}_{2} \mathrm{O}, 0.6 \mathrm{~g} ; \mathrm{CaCl}_{2} \cdot \mathrm{H}_{2} \mathrm{O}, 0.07$ 
g; agar, $15.0 \mathrm{~g}$ (Balkwill and Ghiorse, 1985). The 1\% PTYG agar is a 1:100 dilution of PTYG, except that the concentrations of $\mathrm{MgSO}_{4} \cdot 7 \mathrm{H}_{2} \mathrm{O}, \mathrm{CaCl}_{2} \cdot \mathrm{H}_{2} \mathrm{O}$ and agar are the same as with PTYG. Previous studies have demonstrated that different populations are generally isolated on the two types of media. Therefore, both media were used to get a better approximation of heterotrophic bacterial numbers (Balkwill et al., 1989).

One, 10 and $100 \mathrm{ml}$ samples of well water were filtered through $0.45 \mu \mathrm{m}$ pore size Millipore filters ( $47 \mu \mathrm{m}$ diameter, type HA). Filters were placed on duplicate plates of PTYG and $1 \%$ PTYG, incubated at $27^{\circ} \mathrm{C}$ and read using a binocular microscope (Wild Heerbrug model M5, Switzerland) after 5 days.

Percentage of active cells. The percentage of active cells as measured by acridine orange is believed to be a measure of the percentage of actively growing and synthesizing bacterial cells in the microbial community (Daley, 1979; Lopez-Torres et al., 1988). When acridine orange attaches as a morsomer to double-stranded DNA it will fluoresce green, and when attached as a dimer to single-stranded RNA or denatured DNA it will fluoresce orange-red. Therefore, inactive cells containing mostly double-stranded DNA fluoresce green and actively growing cells with large amounts of RNA should fluoresce orange-red (Daley, 1979). One drawback of this method is that dead cells with denatured DNA would also fluoresce orange-red. For this reason it is important to count discrete cells and not cells that appear to have disrupted membranes. Using this method the percentage of active cells is the percentage of red fluorescing cells in the total community of red and green cells.

Biolog-MPN quantification of sole carbon source utilization. The Biolog technology is based on tetrazolium dye reduction as an indicator of sole-carbon source utilization (Bochner, 1989a; Bochner, 1989b). The Biolog GN microplate (Biolog Inc., Hayward, CA) classifies Gram negative bacteria by testing for 95 different sole carbon sources (Table 2). A study by Garland and Mills (1991) examined bacterial communities 
by the direct addition of water samples to plates but no quantification was made of the densities of bacteria capable of using each carbon source. To quantify the densities of bacteria capable of using each carbon source, the present study combined a most probable number assay and the direct addition of ground water samples to Biolog GN microplates. Ten plates were inoculated directly with ground water. Additional Biolog GN plates were inoculated with ten-fold dilutions of ground water. Plates were placed in whirl-pak bags and incubated at $25^{\circ} \mathrm{C}$ for two weeks. At the end of two weeks the plates were read using a Biolog Microstation System and MicroLog Soitware release 2.01 (Biolog, Inc). The most probable number of bacteria per milliliter was calculated using a Basic computer program written by Hurley and Roscoe (1983).

Data analysis. Two different analysis of variınc: tests using Systat (Systat: Version 5.2 Edition, Evanston, IL) and JMP, version 2 (SAS Institute Inc., Cary, NC), were conducted for density, physical and chemical data. The irst "was a standard singlefactor ANOVA, where variances are assumed to be honoogeneous (Sokal and Rohlf, 1981). However, the Hartley F-max test (Sokal and Rohlf, 1981) revealed significant deviations from homoscedasticity for many of the data exz:nined as so indicated in the appendix. The data for any single factor ANOVA given passed the Hartley Fmax test. Ske.w and kurtosis were reduced by transformation for many of the physical and chemiral parameters. $\log (Y+1)$ transformation allowed the distributions of density data to assume homogeneous variances in most cases. Dissolved oxygen oxidation-reduction potential, conductivity, and trichloroethylene data were transformed using square root, $(\mathrm{Y}+2)^{3}$, arc sine square root, and log transformations, respectively. Of these parameters, transformation allowed the distribution of only one, dissolved oxygen, to assume homogeneous variances. When variances were homoscedastic, pairwise comparisons were made using the Tukey method because it provides narrower confidence limits than methods used for general contrasts. In order to analyze heteroscedastic data a second 


\begin{abstract}
ANOVA test, the Welch ANOVA (Welch, 1951; Brown and Forsythe 1974), was conducted. This test does not require that variances be homogeneous. Data not passing the Hartley Fmax Test was analyzed using the Welch ANOVA. The group means multiple-range-tests of all heteroscedastic data were conducted according to the Games and Howell procedure (Games and Howell, 1976; Sokal and Rohlf, 1981). This method does not assume equal variances or equal sample sizes. When variances are not equal, counter-intuitive results may occur, with closer groups sometimes appearing significantly different while more distant groups with larger variances may not. For all tests a probability level of 0.05 was assumed to be the critical level of significance.
\end{abstract}




\section{RESULTS}

Density of aromatic utilizers. The first objective of this study was to determine the density of select functional groups of bacteria responsible for the degradation of certain naturally occurring and synthetic aromatics in pristine and contaminated ground water environments. The densities of bacteria capable of utilizing the aromatics tested ranged from higher than 800,000 cells per liter (beyond the range of the assay) to less than one cell per liter (below detectable limits) depending on the aromatic compound and the well tested (Table 3).

One area of interest was whether naturally occurring aromatic compounds were utilized by the indigenous species of pristine ground water aquifers. A comparison of the pristine sites, P28 and P29, (Figure 10) demonstrated that the naturally occurring aromatic monomers p-coumarate, ferulate, isovanillate and salicylate were utilized in all six wells. The compound representing a class of contaminants, phenol, was utilized in all the P28 wells but only in the Congaree formation in the P29 well cluster. M-toluate was utilized in the Pee Dee and Middendorf formations of the P28 cluster and only the Congaree in the P29 cluster. Utilizers for all six aromatic compounds were found in well P28TA, a pristine well screened in the Middendorf formation and the deepest well in this study.

Carbon sources utilized by ground water bacteria. In order to study the carbon sources utilized by ground water bacteria in more detail, a method was developed using Biolog-GN microtiter plates in combination with a most probable number enurneration method. Using this method it was possible to quantify the number of bacteria capable of utilizing a variety of additional sole carbon sources. The Biolog sole carbon source $\alpha-D$ glucose was found to be highly correlated with heterotrophic plate counts on $1 \%$ PTYG 
$(r=0.843, d f=7, p<0.01)$ and PTYG $(r=0.804, d f=7, p<0.01)$. This is important since glucose is a major component of PTYG and 1\% PTYG therefore validating the usage of the Biolog MPN method used in this study.

Densities were found to be significantly higher for some classes of carbon compounds. A Welch ANOVA indicated that there were significant differences $(F=13.5$, $\mathrm{df}=2$ and $356.2, \mathrm{p}<0.001$ ) between the densities of utilizers of carboxylic acid, amino acid and carbohydrate utilizers. A Games and Howell multiple-range-comparison test demonstrated that the density of carboxylic acid utilizers was significantly higher as compared to amino acid or carbohydrate sole carbon source densities. Large numbers of different carboxylic acids (Table 4) gave high densities, in contrast to different carbohydrates (Table 5) and amino acids (Table 6). In addition, carbohydrates that gave the highest densities of the carbohydrates tested were those commonly associated with humic acids.

Direct counts and heterotrophic viable counts. The total numbers of bacteria in an aquifer could be an important determinant of the total numbers of aromatic utilizers. Two methods were used to determine bacterial density; acridine orange direct counts and heterotrophic plate counts. Acridine orange direct counts give an indication of the total numbers of all types of bacteria. Heterotrophic plate counts provide an indication of the total number of bacteria that could grow on a particular media under the incubation conditions used. In general, utilizers for each aromatic made up less than $2 \%$ of the bacteria when compared to heterotrophic viable counts on $1 \%$ PTYG agar and a much smaller percentage as compared to direct counts.

Bacterial numbers decreased with increasing depth below the surface. This was true for both methods of bacterial density determination; acridine orange direct counts and heterotrophic plate counts. In addition, the densities for aromatic utilizers were highest in the shallowest wells (depths less than 63 meters) with the exception of the 
DCB7 well. A significant negative correlation between depth and acridine orange direct counts for all wells was observed $(r=-0.224, \mathrm{df}=227, \mathrm{p}<0.01)$. A Welch ANOVA indicated significant differences in bacterial densities for the different wells as determined by acridine orange direct counts $(\mathrm{F}=8.7, \mathrm{df}=10$ and $83.2, \mathrm{P}<0.001)$. Only one site, the P29 site, did not have higher direct counts in the shallower wells (Figure 11). The shallowest well (DCB7) had the highest direct counts which were significantly greater than three of the eleven wells in this study.

As with direct counts there was a significant negative colrelation between depth and viable counts on PTYG ( $r=-0.514, \mathrm{df}=168, \mathrm{p}<0.01)$ and $1 \%$ PTYG $(r=-0.363$, $\mathrm{df}=242, \mathrm{p}<0.01$ ). Single factor ANOVA indicated a significant difference in viable counts between sites on PTYG $(F=20.6, \mathrm{df}=2$ and $87, \mathrm{p}<0.0001)$ and $1 \%$ PTYG $(\mathrm{F}=33.5, \mathrm{df}=2$ and $177, \mathrm{p}<0.0001)$. Densities were significantly higher for ground water samples at the MSB site than either the P28 or P29 sites for PTYG and for 1\% PTYG as determined by Tukey multiple comparison tests. Significant differences were observed between the P29 and P28 sites for densities on either PTYG or 1\% PTYG. There was a significant difference between some well viable counts on PTYG agar $(F=16.3, d f=10$ and 30.7, $\mathrm{p}<0.0001)$ and $1 \%$ PTYG agar $(\mathrm{F}=17.9, \mathrm{df}=10$ and $83, \mathrm{p}<0.0001)$ as determined by Welch ANOVA. Viable counts on 1\% PTYG (Figure 12) were significantly lower for well DCB7 than for the other five shallowest wells, but were not significantly different from the four deep well densities on 1\% PTYG. DCB7 counts were also much lower on PTYG agar but a significant difference was not detected due to the high variance in PTYG counts associated with this well (Figure 13). The four deepest wells each had counts on both media that were significantly lower than all the wells that were shallower except well DCB7. Therefore depth appears to be an important factor influencing both the total numbers of bacteria and species capable of utilizing aromatic compounds. 
Percentage of active cells. A single factor ANOVA demonstrated a significant difference in mean activity between the different wells $(F=8.94, d f=10$ and 209, $\mathrm{P}<0.0001)$. The wells with the highest densities of aromatic utilizers (MSB11B, MSB11C, MSB11D) also had the highest percentage of active cells as measured by acridine orange. The mean activities of wells MSB11B (77\%) and MSB11D (75\%) were significantly higher than well P29TA (53\%) but not P28TA (64\%). The latter two wells are screened in the Middendorf formation. Well DCB7, which had the lowest densities of aromatic utilizers, had the lowest mean activity (28\%) which was significantly lower than all the other wells tested (Figure 14). This lower activity may be a result of the extremely low $\mathrm{pH}$ of this well.

Detection of the XylE gene. The second objective of this study was to determine the innate ability of microbial communities from pristine and contaminated environments to degrade synthetic aromatic compounds. Amplification by the polymerase chain reaction was performed as a means of detection of the catechol 2,3-dioxygenase (XylE) gene. This gene was chosen because it is the ring cleavage gene in the degradation of aromatics by the TOL (toluene degradation) and NAH (naphthalene degradation) plasmids. Enrichments containing minimal media and one of the aromatics (either toluene, $\mathrm{m}$-toluate, salicylate, ferulate, $\mathrm{p}$-coumarate, isovanillate or pherol) were made for all wells. After a two week incubation the enrichments were tested for the presence of the XylE gene sequence. In addition a combined total of over 250 isolates (from the six different aromatic compounds and nine wells) were tested. The positive control, Pseudomonas putida $\mathrm{mt}-2$, gave positive signals (a visible amplicon as detected with gel electrophoresis). No positive signals were observed with either the enrichments or the isolates.

Physical and chemical parameters. The third objective of this study was to examine the ways in which abiotic factors might affect the density and catabolic potential 
of these microbes to degrade aromatics. The temperature, dissolved oxygen, conductivity, redox and salinity were measured simultaneously as samples were taken (Table 7). A two factor ANOVA indicated significant interaction between well and time for temperature, $\mathrm{pH}$, and conductivity. This indicates that over time, these parameters are not changing consistently for the different wells tested. This would be expected since the shallower wells, specifically the wells screened in or above the Congaree formation, would be influenced by changes in precipitation.

Dissolved oxygen. As mentioned previously, depth below the surface appears to be an important factor influencing the density of both aromatic degraders and total numbers of bacteria. One parameter that might be affected by depth is the dissolved oxygen level. Shallower wells are recharged not only from the recharge zone but also from percolation of the water down from the surface therefore higher dissolved oxygen levels in these wells would be expected. A Welch ANOVA indicated significant differences in dissolved oxygen by site $(\mathrm{F}=62.9, \mathrm{df}=2$ and $184.5, \mathrm{P}<0.0001)$ and factorial analysis of variance indicated significant differences in dissolved oxygen by well $(\mathrm{F}=11.7, \mathrm{df}=10$ and $165, \mathrm{P}<0.0001)$. The MSB wells had mean dissolved oxygen levels that ranged from a mean of 6.9 to $7.0 \mathrm{ppm}$. The MSB site (with shallower wells than either the P28 or P29 site) had significantly higher dissolved oxygen than either of these sites. There was not a significant difference between the P29 and P28 dissolved oxygen levels. The lowest mean dissolved oxygen levels were observed in the two deepest wells of the P29 site (Figure 15). Well P29TA and well P29TC had mean dissolved oxygen levels of $2.7 \mathrm{ppm}$ and $2.0 \mathrm{ppm}$ respectively. Well DCB7 $(4.3 \mathrm{ppm})$ had significantly higher dissolved oxygen than the P29 and P28 wells but not the MSB wells. Dissolved oxygen correlated positively with viable counts on both $1 \%$ PTYG $(r=0.176, d f=201$, $\mathrm{p}<0.05)$ and PTYG $(r=0.369, \mathrm{df}=135, \mathrm{p}<0.01)$ agar. Therefore oxygen levels may be one 
of the more important factors influencing density of both total numbers of bacteria and of aromatic utilizers.

Oxidation-reduction potential. The ability of a bacterium to carry out oxidationreduction reactions depends on the oxidation-reduction state of the environment (Atlas and Bartha, 1987). Redox potentials are affected by the oxygen sink or the demand for oxygen itself which is determined by the presence of degradable organic carbon and bacterial activity (Bouwer, 1984). Earlier studies by Fredrickson et al. (1989) indicated that the SRS sediments were not highly reduced. Similar findings were observed in this study, with the oxidation-reduction potential ranging from +0.51 in the $\mathrm{DCB} 7$ well to +0.14 in the P29TC well. Depth appears to be a factor when considering the oxidationreduction potentials of the various wells studied. A significant negative correlation was observed between well depth and oxidation-reduction potential $(r=-0.470, d f=219$, $\mathrm{p}<0.01$ ) and, as would be expected, there was a positive correlation between dissolved oxygen and oxidation-reduction potential $(r=0.363, \mathrm{df}=193, \mathrm{p}<0.01)$. Graphical analysis of the oxidation-reduction potential of the wells (Figure 16) demonstrated a similar pattern as that observed with dissolved oxygen. Wells with depths less than 63 meters had mean oxidation-reduction potentials greater than 0.325 volts whereas wells with depths greater than 63 meters had mean oxidation-reduction potentials less than 0.287 volts. Density may also be influenced by oxidation-reduction potential. The oxidationreduction potential correlated with direct counts $(r=0.152, \mathrm{df}=211, \mathrm{p}<0.01)$ and with viable counts on $1 \%$ PTYG agar $(r=0.240, d f=219, p<0.01)$ and PTYG agar $(r=0.173$, $\mathrm{df}=145, \mathrm{p}<0.05)$. Therefore as with the dissolved oxygen, the oxidation-reduction potential does appear to be more reducing in the deeper wells and may therefore be a factor determining numbers of bacteria specifically aromatic utilizers in these ground water environments. 
Ground water $\mathrm{pH}$. A factor that profoundly affects all microorganisms is $\mathrm{pH}$. Welch ANOVA indicated significant differences in $\mathrm{pH}$ by site $(\mathrm{F}=76.2, \mathrm{df}=2$ and 159 , $\mathrm{P}<0.0001)$ and well $(\mathrm{F}=44.5, \mathrm{df}=9$ and $68.5, \mathrm{p}<0.0001)$. The $\mathrm{P} 28$ site $(\mathrm{pH} 7.4)$ had a significantly greater mean $\mathrm{pH}$ compared to the $\mathrm{P} 29$ site $(\mathrm{pH} 6.0$ ) and MSB site (pH 4.9). Well P28TB (Figure 17) had the highest pH mean (7.27). Well DCB7 had the lowest pH mean ( $\mathrm{pH}$ 2.57). Because of the presence of contaminant polyaromatic hydrocarbons and because direct counts demonstrated high numbers of bacteria present in these wells, the DCB7 well might be expected to have a high number of aromatic utilizers, instead, this well had utilizers for only coumarate and ferulate and densities were low for both compounds (Figure 18). In addition, low viable count densities were also observed. Therefore utilizers of aromatic compounds may be present but unable to acclimate to the higher $\mathrm{pH}$ of the media.

Temperature. The temperature of these ground water wells was extremely stable and did not differ more than one or two degrees over the entire year for any one well. The mean temperature ranged from 18.5 in the MSB11D well to 22.3 for the DCB7 well. A Welch ANOVA demonstrated a significant difference in mean temperature between some of these wells $(F=40.0 ; d f=10$ and $65.5 ; p<0.0001)$, with well $D C B 7$ having a significantly higher mean temperature than 8 of the 10 other wells (Figure 19) as demonstrated by a Games and Howell multiple comparison of means test. The deeper wells, P28TA, TB and A and P29TA, TC had significantly higher temperatures than the shallower wells, e.g., all MSB wells and the P29C well excluding well DCB7.

It is interesting that the shallowest and deepest wells had significantly higher temperatures than wells between these depths. The temperature of ground water responds to seasonal variations in the heat received at the Earth's surface from the Sun and by movement of heat from the Earth's interior. The movement of heat from the Earth's interior causes ground water temperatures to increase with depth. This increase is 
referred to as the geothermal gradient and is approximately $1.8^{\circ} \mathrm{C}$ per $100 \mathrm{~m}$ in areas underlain by thick sections of sedimentary rocks (Heath, 1984). This would explain the significantly higher temperatures of the deeper wells. The increased temperature of the DCB7 could possibly be explained as a result of solar radiation, since it is much shallower than any of the other wells studied.

Temperature correlated with a number of other factors including heterotrophic viable count density and dissolved oxygen but because the variations in temperature between and within each well were so small it is very likely that these correlations were actually due to other factors. For example, the wells with the highest temperatures, DCB7 and the four Middendorf welis (P29TA, P29TC, P28TA and P28TB), had the lowest heterotrophic viable counts. The lower heterotrophic viable counts in the DCB7 well were probably related to the low $\mathrm{pH}$ of that well. The lower heterotrophic viable counts of the Middendorf wells may be a result of the lower dissolved oxygen levels of these wells or to some other depth related factor. Because the range of temperatures between wells and the variations in temperature within a well were so small it is very doubtful that temperature would affect utilization of aromatic compounds in these wells.

Conductivity. Conductivity is a numerical expression of the ability of an aqueous solution to carry an electric current. Factors that affect conductivity include the concentration of ions, and the temperature, among other factors (Clesceri et al., 1989). A Welch ANOVA demonstrated a significant difference between wells $(F=51.3, d f=10$ and 73.9, p<0.0001). Conductivity was significantly higher in the DCB7 well (Figure 20) than all the other wells tested as determined by a Games and Howell multiple comparison of means test. The elevated conductivity of the DCB7 well is most likely due to metal ions associated with the contamination at this site.

Salinity. Salinity was at detectable levels at only the DCB site. The salinity measurements taken by the Hydrolab are based on conductivity. Therefore, the salinity 
values at the DCB7 site are most likely due to the elevated levels of metal ions that are found at this site.

Trichloroethylene. The MSB site, which was highly contaminated with trichloroethylene, had the greatest numbers of aromatic utilizers and all three wells had utilizers for all six aromatics tested. Well MSB11C had the highest mean TCE concentration (147,719 ppb), and MSB11A had the lowest (22 ppb) of the four MSB wells (Figure 21). A decrease in trichloroethylene concentration occurred during this study in some of the wells at the MSB site. This decrease may have been due to the injection of air into wells nearby followed by increased biodegradation, to air stripping processes, or possibly the migration of the contaminant plume away from the MSB site sampled. Significant negative correlations were observed in trichloroethylene concentration over time in 3 of the 4 wells, well MSB11A $(r=-0.867, d f=12, p<0.001)$, $\operatorname{MSB} 11 C(r=-0.7023, \mathrm{df}=7, \mathrm{p}<0.05)$ and MSB11D $(r=-0.9476, \mathrm{df}=12, \mathrm{p}<0.001)$. Contamination of ground water with elevated levels of trichloroethylene did not appear to decrease either the numbers of aromatic degrading bacteria or the total numbers of bacteria. In fact, the MSB wells (Figure 22) had both the highest numbers of aromatic utilizers and all three wells had utilizers for all six of the aromatics tested. Although higher densities were observed for both viable counts and for utilizers of aromatic compounds with bacteria from the MSB wells, it is difficult to determine whether TCE is an important factor determining bacterial numbers. Dissolved oxygen and depth may he a greater influence since the MSB wells are shallower and have higher dissolved oxygen levels than five of the six wells from the P28 and P29 sites. 


\section{DISCUSSION}

Utilization of recalcitrant aromatic compounds in the subsurface. If lignin and humic acid breakdown products such as p-coumarate, ferulate and isovanillate are metabolizable carbon sources being utilized by subsurface bacteria then we might expect utilizers of these compounds to be present in most all the wells tested, and this is what was observed. Even the deepest aquifer tested (P28TA, Middendorf aquifer) had utilizers present for all six of the aromatics tested. The aquifers in both the Pee Dee and Middendorf formations could be considered pristine. The positive head pressures associated with the ground water in the formations below the Congaree causes water movement to be upward to overlying formations (Sargent and Fliermans, 1989). Therefore, contaminants that might exist at the surface would not tend to move downward into the deeper aquifers.

Of the six compounds tested, the highest counts were observed with p-coumarate, ferulate and isovanillate, all of which have been observed as breakdown products of either lignin or humic acid. In addition, an examination of $\mathbf{P}$. putida mt-2 (harboring the TOL plasmid), demonstrated that it was capable of utilizing many of the aromatic substances tested in this study (Table 8). This does tiot necessarily mean that this gene would be involved in the utilization of these other naturally occurring aromatics. It would be an indication that the bacterium is capable of existing on these types of compounds and could have depended on similar compounds for it's existence in it's native environment. This might serve to explain to some degree the origin of these genes.

Other supporting evidence that subsurface bacteria are utilizing lignin and humic acid breakdown products is the differences in density of bacteria utilizing carboxylic acids, carbohydrates and amino acids. As can be observed in Table 4, a large number of 
carboxylic acids were utilized by ground water bacteria. Similar results were found for sediment bacteria (Fredrickson et al., 1991). This may be an indication of what compounds these ground water bacteria are actually subsisting on and are best adapted to. Humic acid molecules have a large number of carboxyl groups associated with them. In addition, cleavage of aromatic ring structures by oxidative reactions results in the formation of carboxylic acids. The type of side group(s) attached to tise aromatic ring would determine the type of carboxylic aromatic produced by oxidation of the aromatic ring. Therefore, we might expect to see greater numbers of utilizers of carboxylic acids by bacteria that are exposed to these compounds in the environment. For most of the wells studied the compounds with the greatest numbers of utilizers were carboxylic acids.

Carbohydrates and amino acids did not appear to be as important as sole carbon sources to ground water bacteria (Table 5 and 6 ). There is evidence that as humics descend through the soil and sediment column many of the readily utilizable carbon sources, for example carbohydrates, are removed. Humic substances in soil commonly vary from 5 to $10 \%$ carbohydrates (Stevenson, 1982). The carbohydrate content of humic substances from a number of different aquifers was tested and all were found to be below the detection limit of $0.1 \%$ (Thurman, 1985). Therefore we might not expect carbohydrate utilization to be as important in ground water environments. With Pseudomonas putida mt-2, sixteen of 24 carboxylic acids were utilized as sole carbon sources whereas only 3 of 28 carbohydrates were utilized (Table 9).

Some carbohydrates are associated with humic acid molecules. Table 10 lists carbohydrates commonly found associated with humic compounds and the relative proportion each makes up of the total carbohydrates (Uzaki and Ishwatari,1983). When these are compared with the carbohydrates giving the greatest densities in the pristine wells (Table 11) it can be seen that all the carbohydrates giving greatest densities are ones commonly associated with humics. In addition, all four of the Middendorf wells had the 
highest carbohydrate densities with L-arabinose as the sole carbon source. Therefore, it appears that bacteria in ground water environments may be adapted to and utilize the carbohydrates associated with humic compounds when these carbohydrates are present.

Interactions between bacteria and contaminants. The highest densities of aromatic utilizers were at the MSB site. This is important because it demonstrates that contamination of ground water with elevated levels of chlorinated hydrocarbons did not decrease the numbers of aromatic degrading bacteria. A number of bacteria have been isolated that are capable of co-metabolizing trichloroethylene while metabolizing aromatic compounds (Harker and Kim, 1990; Nelson et al., 1986; Nelson et al., 1988; Wackett and Gibson, 1988). Prevalence of aromatic degraders at even the deepest aquifers demonstrates that the potential exists that similar bacteria may already be present in ground water that could co-metabolize TCE. Utilizing these indigenous species for bioremediation avoids the pitfalls of introducing genetically engineered species or species not indigenous to these waters. This makes a strong case for using bacteria that are already present in contaminated aquifers as tools for the clean up of the aquifer.

Physical factors such as $\mathrm{pH}$ appear to influence the distribution of aromatic utilizers. Even though we would expect aromatic utilizers to be present in polyaromatic hydrocarbon contaminated water, they were lower in density than the other wells tested and had the least number of different aromatics utilized. Therefore, from what has been observed in this study, the $\mathrm{pH}$ could affect the utilization of the aromatic in two ways. The most immediate affect would be to limit the types of aromatic utilizers able to survive low $\mathrm{pH}$. Another possibility is that many of the bacteria that could utilize these aromatics were unable to acclimate to the higher $\mathrm{pH}$ of the media.

Types of bacteria in Savannah River Site Aquifers. Sinclair and Ghiorse (1989) found that dissolved organic carbon was not a good predictor of microbial abundance. Microbial numbers varied from layer to layer and correlated with changes in sediment, 
pH and concentration of metallic cations. Of all the environmental factors, texture was the best predictor of abundance and activity in the deep subsurface sediments. Sandy samples from deeper formations demonstrated elevated diversity numbers. Low populations of culturable bacteria were found in the high clay sediments. This was possibly due to decreased hydraulic conductivity although the $\mathrm{pH}$ of these sediments was also low (Fredrickson et al., 1989)

The percentage of sand versus clay appears to determine the relative percentages of gram negative and gram positive bacteria. Sinclail and Ghiorse (1989) found a strong association of Gram positive isolates with samples containing more than 50\% clay. These samples yielded $100 \%$ gram-positive and no gram-negative isolates whereas samples containing less than $30 \%$ clay yielded $21 \%$ gram positive and $79 \%$ gramnegative. In no cases were gram positives completely excluded from samples with very high sand content. Isolates from both media (PTYG and 1\% PTYG) and from three of the MSB wells (Table 12) had between $84 \%$ and $96 \%$ gram negative bacteria. This agrees with other studies that have indicated that gram-negative bacteria are more abundant than gram-positive bacteria in sandy aquifer sediments and ground water (Hirsch and Rades-Rohkohl, 1988; Kolbel-Boelke et al., 1988). Gram negative bacteria may be at an adaptive advantage in the dilute aquatic environments of sandy aquifer sediments (Sinclair and Ghiorse, 1989). These advantages include the structure of the gram-negative cell envelope which is believed to provide greater survival advantages in dilute aquatic environments (Brock and Madigan, 1987) and the chemical properties of the outer membrane of grarn negatives which allow for alterations of surface hydrophobicity during cycling between attached and detached states (Beveridge, 1981).

A. PI-NFT on isolates taken from PTYG and 1\% PTYG from three of the MSB wells indicated that a large number of these isolates were possibly Pseudomonads. Balkwill et al. (1989) had similar findings with sediment isolates from the Savannah 
River Site. These included isolates from the P28 and P29 sites. He found that a large number appeared to be Pseudomonads. This would be of possible advantage for in situ bioremediation because this group has been shown to frequently harbor catabolic plasmids (Lindow et al., 1989; Sayler and Blackburn, 1989). Plasmid studies have been conducted at this site on isolates from sediment samples. Fredrickson et al. (1988) demonstrated an increasing frequency of plasmids among isolates with increasing depth at these sites. These plasmids would benefit bacteria in environments where carbon sources are not as readily available. As the environment becomes more recalcitrant it becomes more metabolically economical for the bacteria to increase their plasmid burden in order to increase the number of compounds available for degradation (Hazen et al., 1991).

Role of the XylE gene in utilization of aromatic compounds in ground water environments. One objective of this study was to determine what part a single gene such as the catechol-2,3-dioxygenase (XylE) gene might have on the utilization of aromatics in ground water. Several studies have been conducted that have examined the prevalence of the TOL plasmid in ground water and sediments. A study by Ogunseitan et al. (1987) found there was no homology of TOL DNA with DNA of bacteria from relatively shallow aquifer sediments. Fredrickson et al. (1988) using a whole TOL plasmid probe found homology with plasmids from four bacteria isolated from sediments at the Savannah River Site. In addition, two isolates showed homology with chromosomal regions. Because plasmids which hybridized with whole TOL plasmid probes were found in previous studies in sediments from some of these same formations at the Savannah River Site used in this study it was believed that the XylE sequence should be detectable. Identification of isolates harboring this gene might indicate the prevalence of the sequence and provide some indication of it's involvement in genetic adaptation. Two methods were used in this study to test for the presence of the XylE gene sequence. The 
first method was to examine enrichments. Enrichments for all aromatics including toluene were tested for the presence of the XylE gene. In addition, approximately 250 aromatic utilizers from these ground water samples were examined. These included utilizers of m-toluate, p-coumarate, ferulate, isovanillate, salicylate and phenol. Under stringent conditions (a $60^{\circ} \mathrm{C}$ reannealing step, which was the $\mathrm{Tm}-6^{\circ} \mathrm{C}$ ) none of the isolates demonstrated an amplicon although an amplicon was observed with the model organism (Pseudomonas putida mt-2, which harbors the TOL plasmid).

Therefore, the catechol 2,3 dioxygenase gene found on the TOL and NAH plasmids does not appear to play a role in the degradation of aromatic compounds in these ground water environments. Degradation of aromatic compounds may have been due to diverged genes or different genes altogether. This implies that the homology detected with whole TOL plasmid probes (Fredrickson et al., 1988) may have been to sequences not related to the catabolic pathway that are commonly found on many plasmids (such as sequences for an origin of replication) or to sequences that are related to the pathway but have undergone a high degree of divergence. More specific TOL plasmid probes may better define this homology and aid in the development of new strategies for primer design.

Ground water versus sediment sampling. The nutritional studies performed indicate that under certain conditions ground water sampling may be indicative of what is occurring in the sediments. Comparisons between this study using ground water samples and other studies conducted on sediment samples from this site have been surprisingly similar. Tween 40 and Tween 80 , polymers of fatty acids, were found to be utilized by large numbers of ground water bacteria in this study. This agrees with results from two other subsurface studies. Kolbel-Boelke et al. (1988) found that Tween 40 was commonly metabolized by bacteria! isolates from sediment (71\%) and ground water (52\%). The substrate most commonly metabolized by Middendorf and Cape Fear 
sediment isolates from the Savannah River Site was Tween 40 which was metabolized by $85 \%$ of the isolates. Tween 80 was metabolized by more than $50 \%$ of the isolates (Fredrickson et al., 1991). There are at least two possible explanations for the high densities observed with this compound. The compound may be similar in structure to compounds that are commonly used as a carbon sources in the subsurface. Another possibility is that since the compounds are polymers, and do not readily diffuse into the cell, there is less toxicity to those species that might be inhibited by similar but smaller and more readily diffusible compounds.

Another substrate that was utilized by large numbers of ground water bacteria was b-hydroxybutyric acid. Similar results were observed by Fredrickson et al. (1991). Middendorf and Cape Fear sediment isolates commonly metabolized organic acids and bhydroxybutyric acid. b-hydroxybutyric acid can accumulate intracellularly as the polymer poly-b-hydroxybutyric acid (PHB) in some bacteria and can be an important survival mechanism for bacteria in oligotrophic subsurface environments (Fredrickson et al., 1991). These large granules of reserve material are present in amounts that vary with nutritional conditions and allow storage of carbon in a form that is osmotically inert (Stanier et al., 1986). PHB accumulates during times when carbon sources are abundant and is catabolized during times when nutrients are limited, thereby allowing the cells to maintain viability. Accumulation of PHB occurs under conditions of unbalanced growth, e.g., when an inorganic nutrient such as nitrogen is limiting and utilizable reduced carbon is in excess (Karl, 1986). A study by Sinclair and Ghiorse (1989) demonstrated that $74 \%$ of the bacteria isolated from the deep sandy subsurface at SRS had deposits of a lipophilic storage material assumed to be poly-b-hydroxybutyric acid (Fredrickson et al., 1991). The MSB11C b-Hydroxybutyric acid utilizers had the highest density of any compound tested. 
Results with ground water isolates using API-NFT tests were very similar to studies with sediment isolates. Using API-NFT tests, Balkwill et al. (1989) found that physiological traits of aerobic chemoheterotrophs isolated from Savannah River Site surface soils on both PTYG and 1\% PTYG plating media differed markedly from subsurface isolates. The surface soil bacteria more readily utilized most of the carbon sources offered in the assimilation tests; 8 of the 12 sources were used by at least $75 \%$ (often by more than $85 \%$ ) of the surface soil isolates (compared with 3 of the 12 sources for the subsurface isolates). Similar results were observed in this study with ground water isolates from the MSB site wells. Of the 12 carbohydrates tested for using APINFT, 75\% of the ground water isolates used three or fewer carbohydrates. In Balkwill's study surface and subsurface bacteria responded similarly to the other API tests, except that a significantly larger proportion of the surface soil isolates hydrolyzed esculin and gelatin, whereas a significantly larger percentage of subsurface isolates reduced nitrate. Isolates from the same two isolation media but from ground water and not sediment samples gave similar results (Table 13). As the depth of the well increased from $50 \mathrm{~m}$ (MSB11B weli) to $63 \mathrm{M}$ (MSB11D well) the number of bacteria capable of gelatin hydrolysis decreased and the number capable of nitrate reduction increased. Balkwill found that most of the bacteria isolated on PTYG and 1\% PTYG from sediments at SRS were oxidative rather than fermentative ( $82 \%$ assimilating glucose aerobicaliy but only $4 \%$ fermenting it). Isolates taken from the MSB ground water gave similar results with $74 \%$ assimilating glucose aerobically and none of the isolates fermenting glucose. Similarity in results for assimilation of glucose may be a result of using the same isolation media (PTYG and 1\% PTYG) since there is some selection for isolates that could use glucose aerobically with this media.

Bacterial densities and diversity in ground water. As can be observed in Figure 23, all but one of the wells studied demonstrated higher counts on 1\% PTYG (the low 
nutrient media) than PTYG (the high nutrient media). This demonstrates the oligotrophic nature of these ground water environments. The exception was well DCB7 which had higher PTYG counts. This might be expected since this well had high levels of organic carbon due to polyaromatic hydrocarbon contamination.

In studies by Balkwill et al. (1989) using the same two types of media (PTYG and 1\% PTYG) but with sediment isolates, physiologically distinct types of bacteria were isolated on the two media, with only $11 \%$ overlap between the two groups. Similar differences between the two media were evident as observed from the results of the oxidase tests performed on MSB site isolates taken from the two different media. Oxidase reactions for isolates were very different, $45 \%$ of the PTYG isolates were oxidase positive whereas only $5 \%$ of the $1 \%$ PTYG isolates were oxidase positive (Table 9).

Earlier studies at this site demonstrated that ground water adjacent to sediments had direct counts that were 2-3 orders of magnitude lower and viable counts that were 3-5 orders of magnitude lower than sediment densities. The ratios of direct to viable counts were much greater for ground water samples (Hazen et al, 1991). The acridine orange direct count difference between any of the wells was less than one order of magnitude. This differed from viable counts in which there were several orders of magnitude difference between wells (Figure 24). DCB7, had the lowest viable counts and the highest direct counts. The bacteria in this well may not have been able to acclimate to the higher $\mathrm{pH}$ of the plate count media. This demonstrates that even though bacteria can be visualized and the densities in different aquifers are similar, there are great variations in physiological states and metabolic needs of bacteria in these different aquifers.

A number of sediment studies have been conducted that provide insight into bacterial diversity and numbers in aquifer sediments. Kolbel-Boelke et al. (1988) studied aquifer sediments (depths to $35 \mathrm{~m}$ ) in the Federal Republic of Germany and concluded 
that the microbial community at each depth was both very diverse and distinctly different from those at other depths. Balkwill et al. (1989) reported that different geological formations at the Savannah River Site contained distinct types of bacteria (strains with different API-NFT patterns). Sinclair and Ghiorse (1989) found similar results with samples from the same site. They observed no decline in diversity or numbers with increasing depth. Dramatic differences were observed in the utilization of sole carbon sources between sites and strata in this study. This demonstrates that different approaches might need to be developed that are suitable to the microflora of a particular stratum in order to stimulate the in situ biodegradation of a contaminant at particular site.

The percentage of active cells in ground water environments. Phelps et al. (1989) demonstrated that when comparing sediments from the various formations at the pristine sites the highest activities were in the water-bearing sands of the Congaree. Of the pristine wells, well P29C was the only well studied that lies in the Congaree formation. This well had significantly higher activity than the other two wells studied at the P29 site. There was significantly greater activity from samples from the MSB site as compared to the other sites, P29 and P28. These results were supported by the findings of Phelps et al. (1988). In their study, zones containing TCE concentrations greater than $500 \mathrm{mg}$ per liter were devoid of microbial activity. At the onset of this study the well with the highest TCE concentration, MSB11C, had a mean concentration of TCE of 123,356 ppb, which was well below the level found to be devoid of life. As a whole the MSB site was significantly higher in densities on both PTYG and 1\% PTYG than wells from the other sites. Phelps et al. (1988) found that above and below the TCE laden zones were areas that exhibited greater metabolic activity than near surface soils. As TCE concentrations decreased and water availability increased, microbial activities were greater than in nearsurface sediments. Several other factors may contribute to the increased activity of the MSB wells. The MSB site had significantly higher dissolved oxygen levels as compared 
to the other sites. As a whole, the depths of the wells of this site are shallower as compared to the wells of the P28 site and two of the wells of the P29 site. Well P29C, which was of similar depth with wells in the MSB site, did not differ significantly in activity. Therefore it appears that depth may also have been important in determining activity. In addition, there was a great deal of disturbance to the aquifer sediments by nearby drilling operations that may have increased nutrient levels and activity.

In conclusion, this study demonstrates the importance of aromatic compounds as nutritional sources for bacteria in the subsurface. A number of findings provide supporting evidence. Aromatic utilizers were found in all the geologic formations tested ai: $\mathrm{i} \%$ both contaminated and pristine aquifers. Carboxylic acids (which can be produced by the oxidative cleavage of aromatic ring structures) were found to be an important sole carbon source for ground water bacteria. In addition, carbohydrates giving greatest densities were found to be ones commonly associated with humics. These findings are important since aromatic utilizers in ground water environments may play an important part in the biodegradation of contaminants either metabolically or co-metabolically. The presence of these aromatic utilizers in even the deepest aquifers would indicate that the potential exists for genetic adaptation to xenobiotic compounds with analogous structure in even relatively pristine aquifers. These findings, therefore, have important implications for in situ bioremediation as a method of cleanup of contaminated aquifers. 


\section{CONCLUSIONS}

1. Aromatic monomers that are breakdown products of lignin and humic acid were utilized by bacteria in all the aquifers tested, including the Middendorf, a very deep aquifer.

2. Highest counts for the aromatics tested were on the more common naturally occurring aromatic and humic acid breakdown products.

3. Utilizers of phenol, which represented a class of ground water contaminants, and salicylate, an intermediate in the breakdown of polyaromatic hydrocarbons, were present in all of the pristine aquifers tested.

4. Elevated levels of trichloroethylene, a compound co-metabolized by some aromatic degraders, did not decrease the numbers of bacteria capable of utilizing the aromatics tested.

5. Carboxylic acids appear to be an important source of carbon for bacteria in ground water environments.

6. Carbohydrates utilized by ground water bacteria appear to be those commonly present in humics.

7. Great variations existed in sole carbon source utilization between sites and formations.

8. Ground water may be characteristic of the associated sediments in some aquifers.

9. Shallower aquifers had both higher dissolved oxygen and higher direct counts and heterotrophic viable counts.

10. Several orders of magnitude difference were observed between viable counts from different wells. Direct counts on the same wells varied less than an order of magnitude. This implies that there is a high degree of variation in the physiological states and metabolic needs of the bacteria from the ground water from different formations. 
11. Higher counts were observed on low nutrient media as compared to high nutrient media suggesting that ground waters are predominantly oligotrophic in nature. 


\section{LITERATURE CITED}

Aiken, G. R., D. M. McKnight, R. L. Wershaw, and P. McCarty. 1985. An introduction to humic substances in soil, sediment, and water. p.1-9. In G. R. Aiken, D. M. McKnight, R. L. Wershaw, and P. McCarty (eds), Humic substances in soil, sediment and water: geochemistry, isolation and characterization. John Wiley \& Sons, Inc., New York.

Alexander, M. 1965. Biodegradation: problems of molecular recalcitrance and microbial fallibility. Adv. Appl. Micro. 7: 35-80.

Alexander, M. 1980. Biodegradation of chemicals of environmental concern. Science 211: 132-139.

Atlas, R. M., and R. Bartha. 1987. Microbial Ecology: Fundamentals and Applications. Benjamin/Cummings Co, Menlo Park, California. p. 252-332.

Balkwill, D. L., and W. C. Ghiorse. 1985. Characterization of subsurface bacteria associated with two shallow aquifers in Oklahoma. Appl. Environ. Microbiol. 50:580-588.

Balkwill, D. L., J. K. Fredrickson, and J. M. Thomas. 1989. Vertical and horizontal variations in the physiological diversity of the aerobic chemoheterotrophic 
bacterial microflora in deep southeast coastal plain subsurface sediments. Appl. Environ. Microbiol. 55:1058-1065.

Ball, A. S., W. B. Betts, and A. J. McCarty. 1989. Degradation of lignin-related compounds by actinomycetes. Appl. Environ. Microbiol. 55:1642-1644.

Beringer, J. E., and P. R. Hirsch. 1984. The role of plasmids in microbial ecology. p. 63-70. In Klug, M. J. and C. A. Reddy (eds). Current perspectives in microbial ecology. American Society for Microbiology, Washington, D. C.

Bej, A. K., M. H. Mahbubani, J. L. Dicesare, and R. M. Atlas. 1991. Polymerase chain reaction-gene probe detection of microorganisms by using filter-concentrated samples. Appl. Environ. Microbiol. 57:3529-3534.

Beveridge, T. J. 1981. Ultrastructure, chemistry, and function of the bacterial wall. Int. Rev. Cytol. 72:229-317.

Brown, M. B., and A. B. Forsythe. 1974. Robust tests for the equality of variances. J. Am. Statist. Assoc. 69:364-367.

Bochner, B. 1989a. Breath prints at the microbial level. ASM News 55:536-539..

Bochner, B. 1989b. Sleuthing out bacterial identities. Nature 339:157. 
Bouwer, H. 1984. Elements of soil science and ground water hydrology. p. 9-38. In Bitton, G. and Gerba, C. P. (eds) Groundwater Pollution Microbiology. John Wiley and Sons. New York, NY.

Brock, T. D., and M. Madigan. 1988. Biology of microorganisms, 5th ed. Prentice-Hall, Englewoods Cliff, NJ. p. 76-77.

Brownlow, A. H. 1979. Geochemistry. Prentice-Hall, Inc., Inglewood Cliffs, NJ.

Burlage, R. S., S. W. Hooper, and G. S. Sayler. 1989. The TOL (pWWO) catabolic plasmid. Appl. Environ. Microbiol. 55: 1323-1328.

Campbell, C. A., E. A. Paul, D. A. Rennie, and K. J. McCallum. 1967. Applicability of the carbon-dating method of analysis to soil humus studies. Soil Sci. 104:217224.

Cerniglia, C. E. 1984. Microbial transformation of aromatic hydrocarbons. p. 99-128. In R. M. Atlas (ed.), Petroleum microbiology. Macmillan Publishing Co., London.

Chakrabarty, A. M. 1972. Genetic basis of the biodegradation of salicylate in Pseudomonas. J. Bacteriol. 112: 815-823.

Chakrabarty, A. M., G. Chou, and I. C. Gunsalus. 1973. Genetic regulation of octane dissimilation plasmid in Pseudomonas. Proc. Natl. Acad. Sci. U. S. A. 70: 1137 1140. 
Chen, C. L., H. M. Chang, and T. K. Kirk. 1982. Aromatic acids produced during degradation of lignin in spruce wood by Phanerochaete chrysosporium. Holzforschung 36:3-9.

Clarke, P. H. 1984 Evolution of new phenotypes. p. 71-78. In Klug, M. J. and C. A. Reddy (eds). Current perspectives in microbial ecology. American Society for Microbiology, Washington, D. C.

Clesceri, L. S., A. E. Greenberg, and R. Rhodes Trussell (ed.). 1989. 17th edition. p.. 257 - 2-59. Standard methods for the examination of water and wastewater. American Public Health Association, Washington D. C.

Cornelis, G., D. Ghosal, and H. Saedler. 1978. Tn951: a new transposon carrying a lactose operon. Mol. Gen. Genet. 160:215-224.

Crawford, R. L. 1981. Lignin biodegradation and transformation. John Wiley \& Sons, Inc., New York.

Crawford, R. L., and D. L. Crawford. 1984. Recent advances in studies of the mechanisms of microbial degradation of lignins. Enzyme Micro. Technol. 6:434442.

Crosa, J. H., and S. Falkow. 1981. Plasmids. Manual of Methods for General Microbiology. Washington, D. C., ASM. 
Daley, R. J. 1979. Direct epifluorescence enumeration of native aquatic bacteria: uses, limitations, and comparative accuracy. In: Costerton J. W., Colwell R. R. (eds) Native aquatic bacteria: enumeration, activity, and ecology. American Society for Testing Materials. Philadelphia.

Dobbins, D. C., J. R. Thorton-Manning, D. D. Jones, and T. W. Federle. 1987. Mineralization potential for phenol in subsurface soils. J. Environ. Qual. 16:5458.

Donnelly, P. K., and D. L. Crawford. 1988. Production by Streptomyces viridosporus T7A of an enzyme which cleaves aromatic acids form lignocellulose. Appl. Environ. Microbiol. 54:2237-2244.

Dunn, N. W., and I. C. Gunsalus. 1973. Transmissible plasmid coding early enzymes of naphthalene oxidation in Pseudomonas putida. J. Bacteriol. 114: 974-979.

Federle, T. W. 1988. Mineralization of monosubstituted aromatic compounds in unsaturated aromatic compounds in unsaturated and saturated subsurface soils. Can. J. Microbiol. 34:1037-1042.

Fewson, C. A. 1988. Biodegradation of xenobiotic and other persistent compounds: the causes of recalcitrance. Tibtech. 6: 148-153.

Fliermans, C. B., and D. L. Balkwill. 1989. Microbial life in deep terrestrial subsurfaces. BioScience 39:370-377. 
Fredrickson, J. K., and R. J. Hicks. 1987. Probing reveals many microbes beneath Earth's surface. ASM News. 53: 78-79.

Fredrickson, J. K., D. L. Balkwill, J. M. Zachara, S. W. Li, F. J. Brockman, and M. A. Simmons. 1991. Physiological diversity and distributions of heterotrophic bacteria in deep Cretaceous sediments of the Atlantic coastal plain. Appl. Environ. Microbiol. 57:402-411.

Fredrickson, J. K., T. R. Garland, R. J. Hicks, J. M. Thomas, S. W. Li, and K. M. McFadden. 1989. Lithotrophic and heterotrophic bacteria in deep subsurface sediments and their relation to sediment properties. Geomicrobiol. J. 7:53-66.

Fredrickson, J. K., R. J. Hicks, S. W. Li, and F. J. Brockman. 1988. Plasmid incidence in bacteria from deep subsurface sediments. Appl. Environ. Microbiol. 54:29162923.

Games, P. A., and J. F. Howell. 1976. Pairwise multiple comparison procedures with unequal N's and/or variances: A Monte Carlo study. J. Educ. Stat. 1:113-125.

Garland, J. L., and A. L. Mills. 1991. Classification and characterization of heterotrophic microbial communities on the basis of patterns of community-level sole-carbon-source utilization. Appl. Environ. Microbiol. 57:2351-2359.

Ghiorse, W. C., and D. L. Balkwill. 1983. Enumeration and morphological characterization of bacteria indigenous to subsurface environments. Dev. Indust. Microbiol. 24: 213-224. 
Ghiorse, W. C., and J. T. Wilson. 1988. Microbial ecology of the terrestrial subsurface. In A. I. Laskin (ed.) Adv. Appl. Microbiol. Vol. 33:107-171.

Goldsmith, E., and N. Hilyard. 1988. The Earth report. Price Stern Sloan, Inc., Los Angeles p. 216.

Gonzalez, B., A. Merino, M. Almeida, and R. Vicna. 1986. Comparative growth of natural bacterial isolates on various lignin-related compounds. Appl. Environ. Microbiol. 52:1428-1432.

Hall, B. 1984. Adaptation by acquisition of novel enzyme activities in the laboratory. p. 79-86. In Klug, M. J. and C. A. Reddy (eds). Current perspectives in microbial ecology. American Society for Microbiology, Washington, D. C.

Harayama, S., M. Rekik, A. Wasserfallen, and A. Bairoch. 1987. Evolutionary relationships between catabolic pethways for aromatics: conservation of gene order and nucleotide sequences of catechol oxidation genes of pWWO and NAH7 plasmids. Mol. Gen. Genet. 210: 241-247.

Hardy, K. 1986. Bacterial Plasmids. Aspects of Microbiology. American Society for Microbiology, Washington, D. C. p. 23-96.

Harker, A. R., and Y. Kim. 1990. Trichloroethylene degradation by two independent aromatic-degrading pathways in Alcaligenes eutrophus JMP134. Appl. Environ. Microbiol. 56:1179-1181. 
Harvey, R. W., R. L. Smith, and L. George. 1984. Effect of organic contamination upon microbial distributions and heterotrophic uptake in a Cape Cod, Mass., Aquifer. Appl. Environ. Microbiol. 48: 1197-1202.

Hazen, T. C., L. Jiménez, G. López de Victoria, and C. B. Fliermans. 1991. Comparison of bacteria from deep subsurface sediment and adjacent ground water. Microb. Ecol. 22:293-304.

Heath, R. C. 1984. Basic Ground-water hydrology. U. S. Geological Survey WaterSupply Paper 2220. US Geological Survey, Alexandria, Virginia. p. 70.

Heffron, F., R. Sublett, R. W. Hedges, A. Jacob, and S. Falkow. 1975. Origin of the TEM beta-lactamase gene found on plasmids. J. Bacteriol. 122:250-256.

Hicks, R. J., and J. K. Fredrickson. 1989. Aerobic metabolic potential of microbial populations indigenous to deep subsurface environments. Geomicrobiol. J. 7:6777.

Hirsch, P. and Rades-Rohkohl, E. 1988. Some special problems in the determination of viable counts of groundwater microorganisms. Microbial Ecology. 16:99-113

Horiuchi, T., J. T. Tomizawa, and A. Novick. 1962. Isolation and properties of bacteria capable of high rates of $b$-galactoside synthesis. Biochem. Biophys. Acta. $55: 152-163$. 
Horvath, R. S. 1972. Microbial co-metabolism and the degradation of organic compounds in nature. Bacteriol. Rev. 36: 146-155.

Hughes, E. J. L., R. C. Bayley, and R. A. Skurry. 1984. Characterization of a TOL-like plasmid from Alkaligenes eutrophus that controls expression of a chromosomally encoded p-creosol pathway. J. Bacteriol. 158: 73-78.

Hurley, M. A., and M. E. Roscoe. 1983. Automated statistical analysis of microbial enumeration by dilution series. J. Appl. Bacteriol. 55:159-164.

Inderlied, C. B., and R. P. Mortlock. 1977. Growth of Klebsiella aerogenes on xylitol: implications for bacterial evolution. J. Mol. Evol. 9:181-190.

Innes, M. A., and D. H. Gelfand. 1990. Optimization of PCRs. p. 3-12. In M. A. Innes, D. H. Gelfand, J. J. Sninsky, T. J. White. PCR Protocols. Academic Press, Inc. New York.

Jenkinson, D. S., and J. H. Rayner. 1977. The turnover of soil organic matter in sole of the Rothansted classical experiments. Soil Sci. 123:298-305.

Jiménez, L. 1989. Molecular analysis of deep subsurface bacteria. Doctoral thesis. University of Puerto Rico at Rio Piedras. p. 6-8.

Karl, D. M. 1986. Determination of in situ microbial biomass, viability, metabolism, and growth. p. 85-159. In Leadbetter, E. R. and J. S. Poindexter (eds). Bacteria in 
nature: methods and special applications in bacterial ecology. Vol. 2. Plenum Press, New York.

Kellogg, S. T., D. K. Chatterjee, and A. M. Chakrabarty. 1981. Plasmid-assisted molecular breeding: new technique for enhanced biodegradation of persistent toxic chemicals. Science $214: 1133-1135$.

Keswick, B. H. 1984. Sources of ground water pollution. p. 39-64. In Bitton, G. and Gerba, C. P. (eds) Ground water Pollution Microbiology. John Wiley and Sons. New York, NY.

Knackmuss, H. J. 1981. Degradation of halogenated and sulfonated hydrocarbons. In T. Leisinger, A. M. Cook, R. Hutter, and J. Nuesch (eds), Microbial degradation of xenobiotics and recalcitrant compounds. Academic Press, London. p. 189-212.

Knox, C. E. 1988. What's going on down there? Pervasive ground water contamination prompts new cleanup approaches. $134: 362-365$.

Kolbel-Boelke, J., E. M. Anders, and A. Nehrkorn. 1988. Microbial communities in the saturated ground water environment II: Diversity of bacterial communities in a Pleistocene sand aquifer and their in vitro activities. Microb. Ecol. 16:31-48.

Kuznetsov, S. I., G. A. Dubinina, and N. A. Laptera. 1979. Biology of oligotrophic bacteria. Ann. Rev. Microbiol. 33: 377-387. 
Lee, G. F., and R. A. Jones. 1983. Guidelines for sampling ground water. J. Water Pollution Control Fed. 55:92-96.

Leenheer, J. A.., Malcolm, R. L., McKinley, P. W., and L. A. Eccles. 1974. Occurrence of dissolved organic carbon in selected ground water samples in the United States. U. S. Geol. Surv. J. Res. 2: 361-369.

Lindow, S. E., N. J. Panopoulas, and B. L. McFarland. 1989. Genetic engineering of bacteria from managed and natural habitats. Science 244: 1300-1307.

Lopez de Victoria, G. 1989. Chemotactic behavior of deep subsurface bacteria toward carbohydrates, amino acids and a chlorinated alkene. Master thesis. University of Puerto Rico at Rio Piedras.

Lopez-Torres, A. J., L. Prieto and T. C. Hazen. 1988. Comparison of the i situ survival and activity of Klebsiella pneumoniae and Escherichia coli in tropical marine environments. Micro. Ecol. 15:41-57.

MacRae, I. C. 1989. Microbial metabolism of pesticides and structurally related compounds. Rev. Environ. Contam. Toxicol. 109:1-87.

McCarty, P. L., B. E. Rittmann, and E. J. Bouwer. 1984. Microbiological processes affecting chemical transformations in ground water. In Bitton, G. and Gerba, C. P. (eds) Groundwater Pollution Microbiology. John Wiley and Sons, New York. 
McNabb, J. F., and G. E. Mallard. 1984. Microbiological sampling in the assessment of ground water pollution. In Bitton, G. and Gerba, C. P. (eds) Groundwater Pollution Microbiology. John Wiley and Sons, New York.

Micure, J. P. 1980. Determining volatile organics in water. Environ. Sci. Technol. $14: 931-935$.

Mortlock, R. P. 1981. Regulatory mutations and the development of new metabolic pathways in bacteria. Evol. Biol. 14:205-267

Nelson, M. J. K., S. O. Montgomery, E. J. O'Neill, and P. H. Pritchard. 1986. Aerobic metabolism of trichloroethylene by a bacterial isolate. Appl. Environ. Microbiol. 52: 383-384.

Nelson, M. J. K., S. O. Montgomery, and P. H. Pritchard. 1988. Trichloroethylene metabolism by microorganisms that degrade aromatic compounds. Appl. Environ. Microbiol. 54: 604-606.

Ogunseitan, O. A., E. T. Tedford, D. Pacia, K. M. Sirotkin, and G. S. Sayler. 1987. Distribution of plasmids in ground water bacteria. J. Ind. Microbiol. 1:311:317.

Phelps, T. J., D. B. Hedrick, D. Ringelberg, C. B. Fliermans, and D. C. White. 1989. Utility of radiotracer activity measurements for subsurface microbiology studies. J. Microbiol. Met. 9:15-27. 
Phelps, T. J., D. Ringelberg, D. Hedrick, J. Davis, C. B. Fliermans, and D. C. White. 1988. Microbial biomass and activities associated with subsurface environments contaminated with chlorinated hydrocarbons. Geomicrobiol. J. 6:157-170.

Poindexter, J. 1981. Oligotrophy: fast and famine existence. Adv. Microb. Ecol. 5: 6390.

Pye, V., and R. Patrick. 1983. Ground water contamination in the United States. Science 221: 713-721.

Rheinwald, J. G., A. M. Chakrabarty, and I. C. Gunsalus. 1973. A transmissible plasmid controlling camphor oxidation in Pseudomonas putida. Proc. Nat. Acad. Sci. U. S. A. $70: 885-889$.

Rigby, P. W. J., B. D. Burleigh, and B. S. Hartley. 1974. Gene duplication in experimental enzymes evolution. Nature 251:200-204.

Saiki, R. K., D. H. Gelfand, S. Stoeffel, S. J. Scharf, R. Higuchi, G. T. Horn, K. B. Mullis, and H. A. Erlich. 1988. Primer-directed enzymatic amplification of DNA with a thermostable DNA polymerase. Science 239: 487-490.

Sambrook, J, E. F. Fritsch, and T. Maniatis. 1989. Molecular cloning: a laboratory manual. Cold Spring Harbor Laboratory Press, Cold Spring Harbor, New York. 
Sargent, K. A., and C. B. Fliermans. 1989. Geology and hydrology of the deep subsurface microbiology sampling sites at the Savannah River Plant, South Carolina. Geomicrobiol. J. 7:3-13.

Sayler, G. S., and J. W. Blackburn. 1989. Modern biological methods: the role of biotechnology. In Biotreatment of Agricultural Wastewater. CRC Press, Inc. P. 53-71.

Schell, M. A. 1985. Transcriptional control of the nah and sal hydrocarbon degradation operons by the nahR gene product. Gene 36:301-309.

Shapiro, S. S., M. B. Wilk, and H. J. Chen. 1968. A comparative study of various tests for normality. J. Amer. Statist. Assoc. 63: 1343-1372.

Sinclair, J. L., and W. C. Ghiorse. 1989. Distribution of aerobic bacteria, protozoa, algae and fungi in deep subsurface sediments. Geomicrobiol. J. 7:15-31.

Sinclair, M. I., P. C. Maxwell, B. R. Lyon, and B. W. Holloway. 1987. Chromosomal location of TOL plasmid DNA in Pseudomonas putida. J. Bacteriol. 168: 13021308.

Slater, J. H. 1984. Genetic interactions in microbial communities. p. 87-93. In Klug, M. J. and C. A. Reddy (eds). Current perspectives in microbial ecology. American Society for Microbiology, Washington, D. C. 
Sokal, R. R., and F. J. Rohlf. 1981. Biometry. Second edition. W. H. Freeman, San Francisco, CA.

Stanier, R. Y., J. L. Ingraham, M. L. Wheelis, and P. R. Painter. 1986. The Microbial World. 5th edition. Prentice Hall, Englewood Cliffs, New Jersey. p. 176-177.

Stanier, R. Y., N. J. Palleroni, and M. Doudoroff. 1966. The aerobic Pseudomonads: a taxonomic study. J. Gen. Microbiol. 43:159-271.

Stevenson, F. J. 1982. Humus chemistry; Genesis, Composition, Reactions. WileyInterscience, New York.

Stout, J. D., K. M. Goh, and T. A. Rafter. 1981. Chemistry and turnover of naturally occurring resistant organic compounds in soil, p. 1-73. In E. A. Paul and J. N. Lass (ed.), Soil biochemistry, vol. 5. Marcel Dekker, Inc., New York.

Suflita, J. M., and G. D. Miller. 1985. Microbial metabolism of chlorophenolic compounds in ground water aquifers. Environ. Toxicol. Chem. 4:751-758.

Thurman, E. M. 1985. Humic substances in ground water, p. 87-104. In G. R. Aiken, D. M. McKnight, R. L. Wershaw, and P. McCarty (ed.), Humic Substances in Soil, Sediment and Water, Wiley-Interscience, New York.

U. S. Environmental Protection Agency. 1987. Handbook: Ground water. EPA/625/687/016. Center for Environmental Protection Agency, Cincinnati, OH. 
Uzaki, M., and Ishwatari, R. 1983. Determination of cellulose and non-cellulose carbohydrates in recent sediments by gas chromatography. J. Chromatogr. 260:487-492.

Ventullo, R. M., and R. J. Larson. 1985. Metabolic diversity and activity of heterotrophic bacteria in ground water. Environ. Toxicol. Chem. 4:759-771.

Wackett, L., and D. Gibson. 1983. Degradation of trichloroethylene by toluene dioxygenase in whole-cell studies with Pseudomonas putida F1. Appl. Environ. Microbiol. 54:1703-1708.

Waksman, S. A. 1916. Bacterial numbers in soil, at different depths, and in different seasons of the year. Soil Sci. 1: 363-380.

Wallis, P. M., H. B. M. Hynes, and S. A. Telang. 1981. The importance of ground water in the transportation of allochthonous dissolved organic matter to the streams draining a small mountain basin. Hydrobiologia 79:77-90.

Ward, T. E. 1985. Characterizing the aerobic and anaerobic microbial activities in surface and subsurface soils. Environ. Toxicol. Chem. 4:727-735.

Welch, B. L. 1951. On the comparison of several mean values: an alternative approach. Biometrika 38:330-336. 
White, D. C., H. F. Fredrickson, M. J. Gehron, G. A. Smith, and R. F. Martz. 1983. The ground water aquifer microbiota: biomass, community structure, and nutritional status. Dev. Indust. Microbiol. 24: 189-199.

Wickham, G. S., and R. M. Atlas. 1988. Plasmid frequency fluctuations in bacterial populations from chemically stressed soil communities. Appl. Environ. Microbiol. 54: 2192-2196.

Williams, P. A., and K. Murray. 1974. Metabolism of benzoate and the methylbenzoates by Pseudomonas putida (arvilla) mt-2: evidence for the existence of a TOL plasmid. J. Bacteriol. 120: 416-423.

Williams, P. A., and M. J. Worsey. 1976. Ubiquity of plasmids in coding for toluene and xylene metabolism in soil bacteria: evidence for the existence of new TOL plasmids. J. Bacteriol. 125: 818-828.

Wilson, J. T., and J. F. McNabb. 1983. Biological transformation of organic pollutants in ground water. EOS, Transactions, American Geophysical Union. 64: 505-507.

Wilson, J. T., L. E. Leach, M. Henson, and J. N. Jones. 1986. In situ biorestoration as a ground water technique. Ground Water Monitor. Rev.. Fall. 1986: 56-64.

Wilson, J. T., J. F. McNabb, D. L. Balkwill, and W. C. Ghiorse. 1983b. Enumeration and characterization of bacteria indigenous to a shallow water-table aquifer. Ground Water 21: 225-233. 
Wilson, J. T., J. F. McNabb, B. H. Wilson, and M. J. Noonan. 1983a. Biotransformation of selected organic pollutants in ground water. Dev. Ind. Microbiol. 24:225-233.

Wilson, J. T., J. F. McNabb, D. L. Balkwill, and W. C. Ghiorse. 1983b. Enumeration and characterization of bacteria indigenous to a shallow water-table aquifer. Ground Water 21: 225-233.

Wilson, J. T. and B. H. Wilson. 1985. Biotransformation of trichloroethylene in soil. Appl. Environ. Microbiol. 49:242-243.

Zar, C. R. 1984. Biostatistical analysis. Second Edition. Prentice-Hall Inc., Englewood Cliffs, N. J.

Zelkus, J. G. 1981. Lignin metabolism and the Calvin cycle. Polymer biosynthesis, biodegradation, and Environmental Recalcitrance. In M. Alexander (ed.), Advances in Microbial Ecology. Plenum Press, New York. 
Table 1.

Screened interval for ground water wells sampled in this study.

\begin{tabular}{llr}
\hline Site & Well & $\begin{array}{c}\text { Screened interval } \\
\text { (meters) }\end{array}$ \\
\hline P28 & P28A & $101-104$ \\
& P28TB & $188-195$ \\
& P28TA & $228-238$ \\
P29 & P29C & $40-43$ \\
& P29TC & $149-155$ \\
& P29TA & $204-210$ \\
MSB & MSB11A & $40-43$ \\
& MSB11B & $49-51$ \\
& MSB11C & $54-$ \\
& MSB11D & $62-$ \\
DCB & DCB7 & $33-39$ \\
\hline
\end{tabular}


Table 2.

Sole Carbon Sources in Biolog GN Microtitre Plates.

Carbon Sources

\begin{tabular}{|c|c|c|}
\hline Carbohydrates & Carboxylic acids & Amino Acids \\
\hline $\begin{array}{l}\text { N-Acetyl-D-galactosamine } \\
\text { N-Acetyl-D-glucosamine } \\
\text { Adonitol } \\
\text { L-Arabinose } \\
\text { D-Arabitol } \\
\text { Cellobiose } \\
\text { i-Erythritol } \\
\text { D-Fructose } \\
\text { L-Fucose } \\
\text { D-Galactose } \\
\text { Gentiobiose } \\
\alpha \text {-D-Glucose } \\
\text { m-Inositol } \\
\alpha \text {-D-Lactose } \\
\text { Lactulose } \\
\text { Maltose } \\
\text { D-Mannitol } \\
\text { D-Mannose } \\
\text { D-Melibiose } \\
\beta \text {-Methyl D-glucoside } \\
\text { D-Psicose } \\
\text { D-Raffinose } \\
\text { L-Rhamnose } \\
\text { D-Sorbitol } \\
\text { Sucrose } \\
\text { D-Trehalose } \\
\text { Turanose } \\
\text { Xylitol }\end{array}$ & 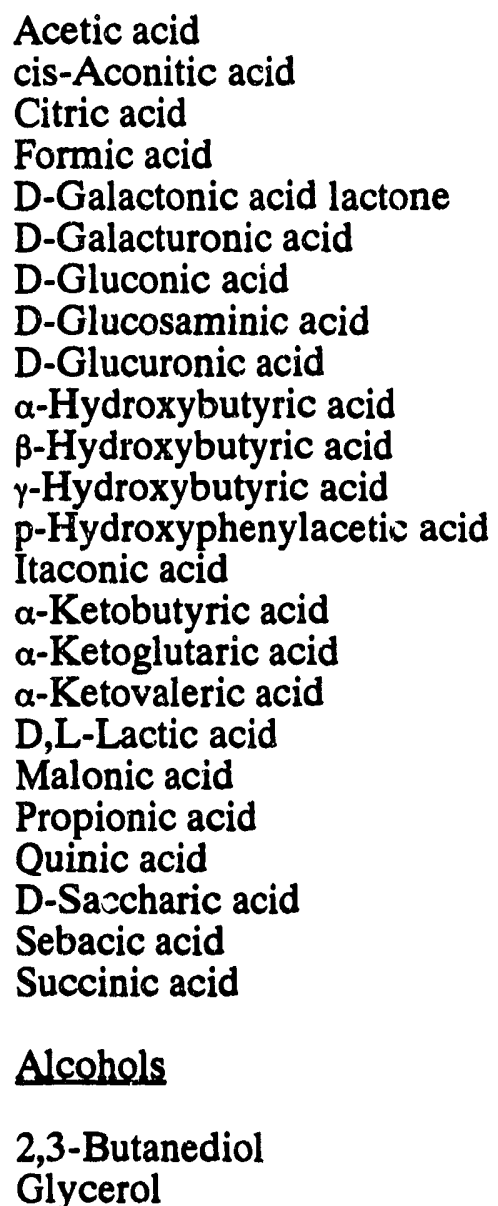 & $\begin{array}{l}\text { D-Alanine } \\
\text { L-Alanine } \\
\text { L-Alanylglycine } \\
\text { L-Asparagine } \\
\text { L-Aspartic acid } \\
\text { L-Glutamic acid } \\
\text { Glycyl-L-asparitic acid } \\
\text { Glycyl-L-glutamic acid } \\
\text { L-Histidine } \\
\text { Hydroxy-L-proline } \\
\text { L-Leucine } \\
\text { L-Ornithine } \\
\text { L-Phenylalanine } \\
\text { L-Proline } \\
\text { L-Pyroglutamic acid } \\
\text { D-Serine } \\
\text { L-Serine } \\
\text { L-Threonine } \\
\text { D,L-Carnitine } \\
\text { y-Aminobutyric acid } \\
\text { Aromatics } \\
\text { Urocanic acid } \\
\text { Inosine } \\
\text { Uridine } \\
\text { Thymidine }\end{array}$ \\
\hline Esters & Amides & Bromosuccinic acid \\
\hline $\begin{array}{l}\text { Methylpyruvate } \\
\text { Mono-methylsuccinate }\end{array}$ & $\begin{array}{l}\text { Succinamic acid } \\
\text { Glucuronamide }\end{array}$ & Amines \\
\hline $\begin{array}{l}\alpha-\text { Cyclodextrin } \\
\text { Dextrin } \\
\text { Glycogen } \\
\text { Tween4C } \\
\text { Tween } 80\end{array}$ & $\begin{array}{l}\text { Phosphoralated Compounds } \\
\text { D,L- } \alpha-\text { Glycerol phosphate } \\
\text { Glucose-1 phosphate } \\
\text { Glucose-6-phosphate }\end{array}$ & $\begin{array}{l}\text { Phenylethylamine } \\
\text { Putrescine } \\
\text { 2-Aminoethanol }\end{array}$ \\
\hline
\end{tabular}




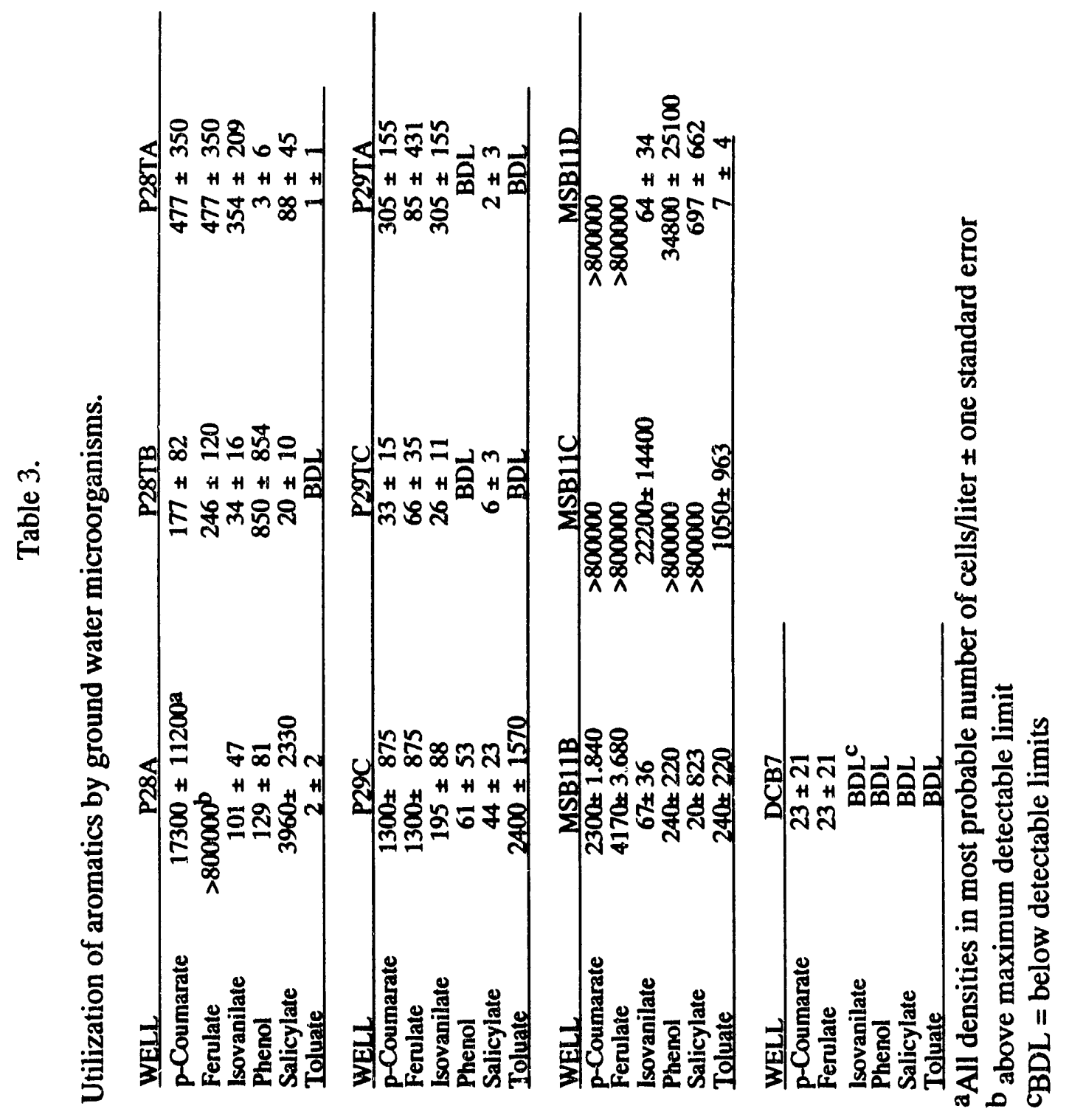




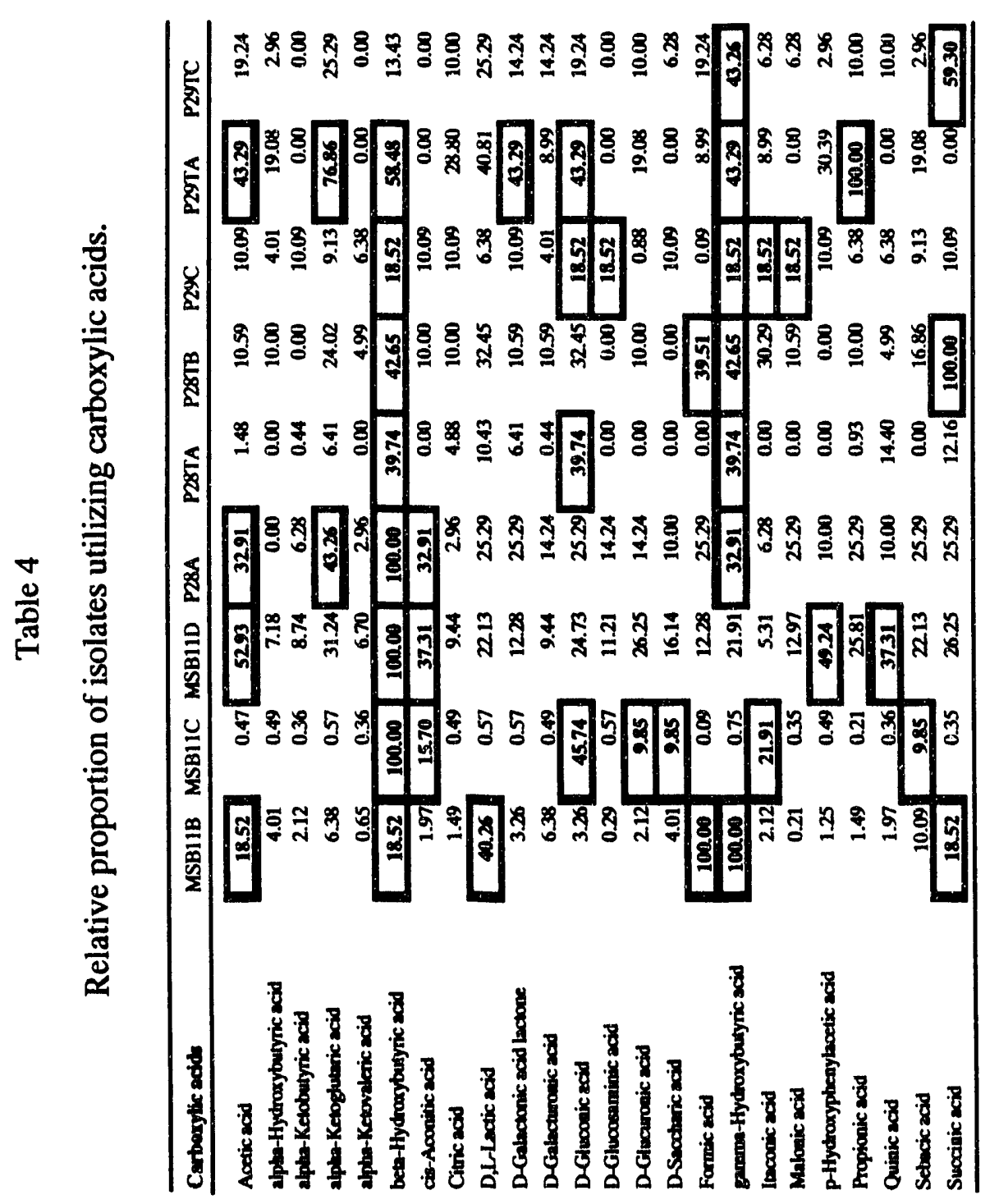

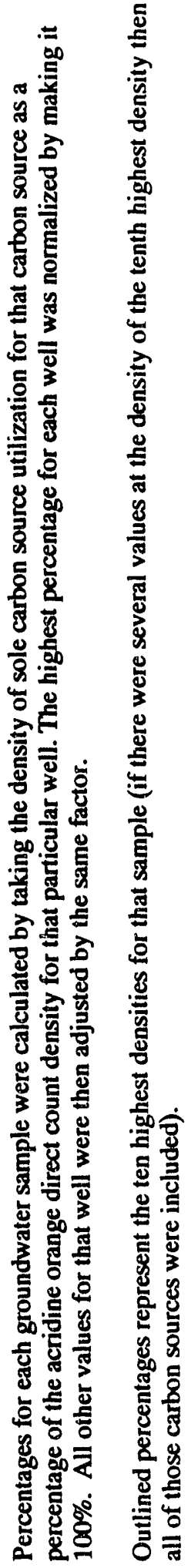




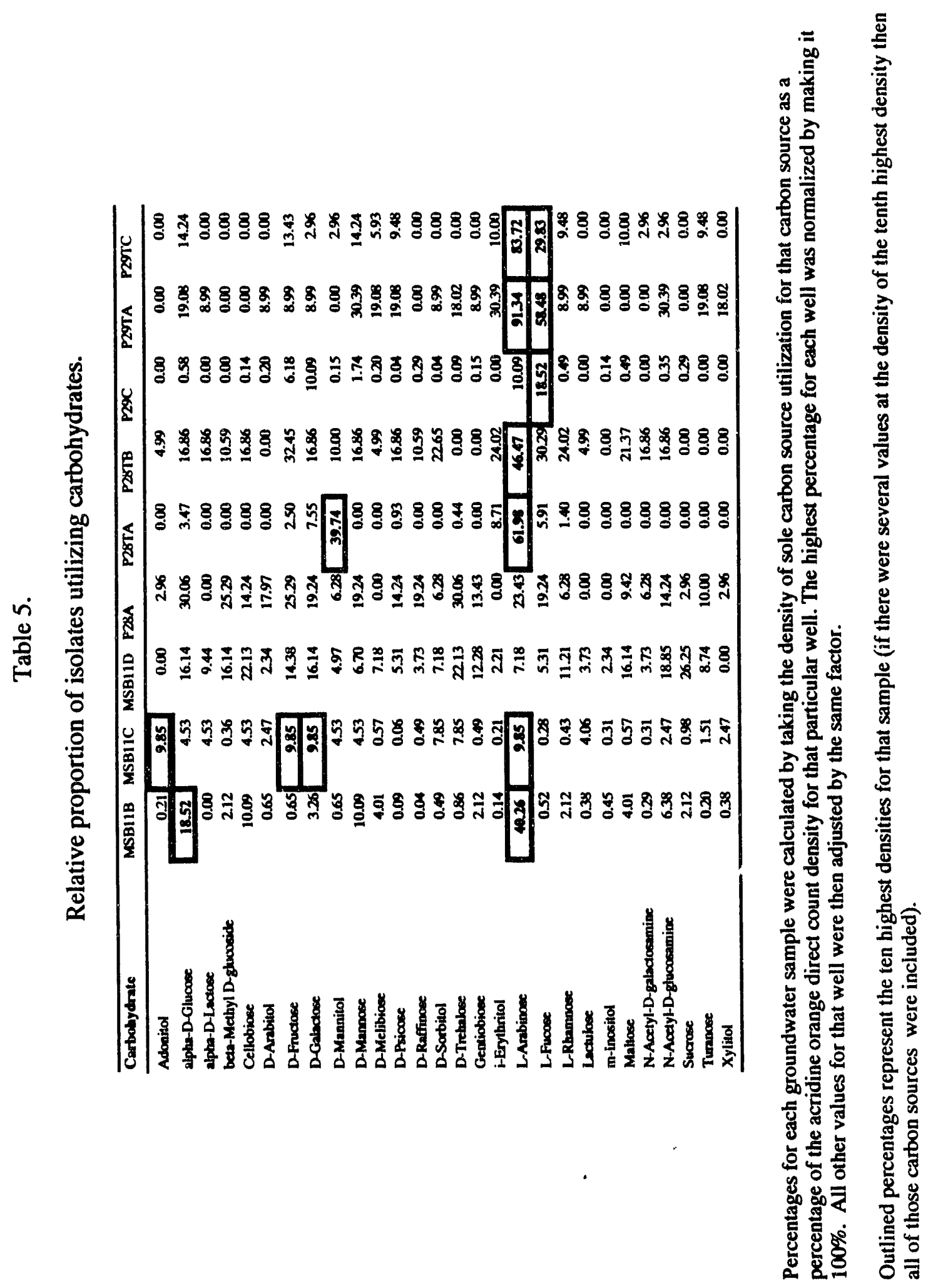




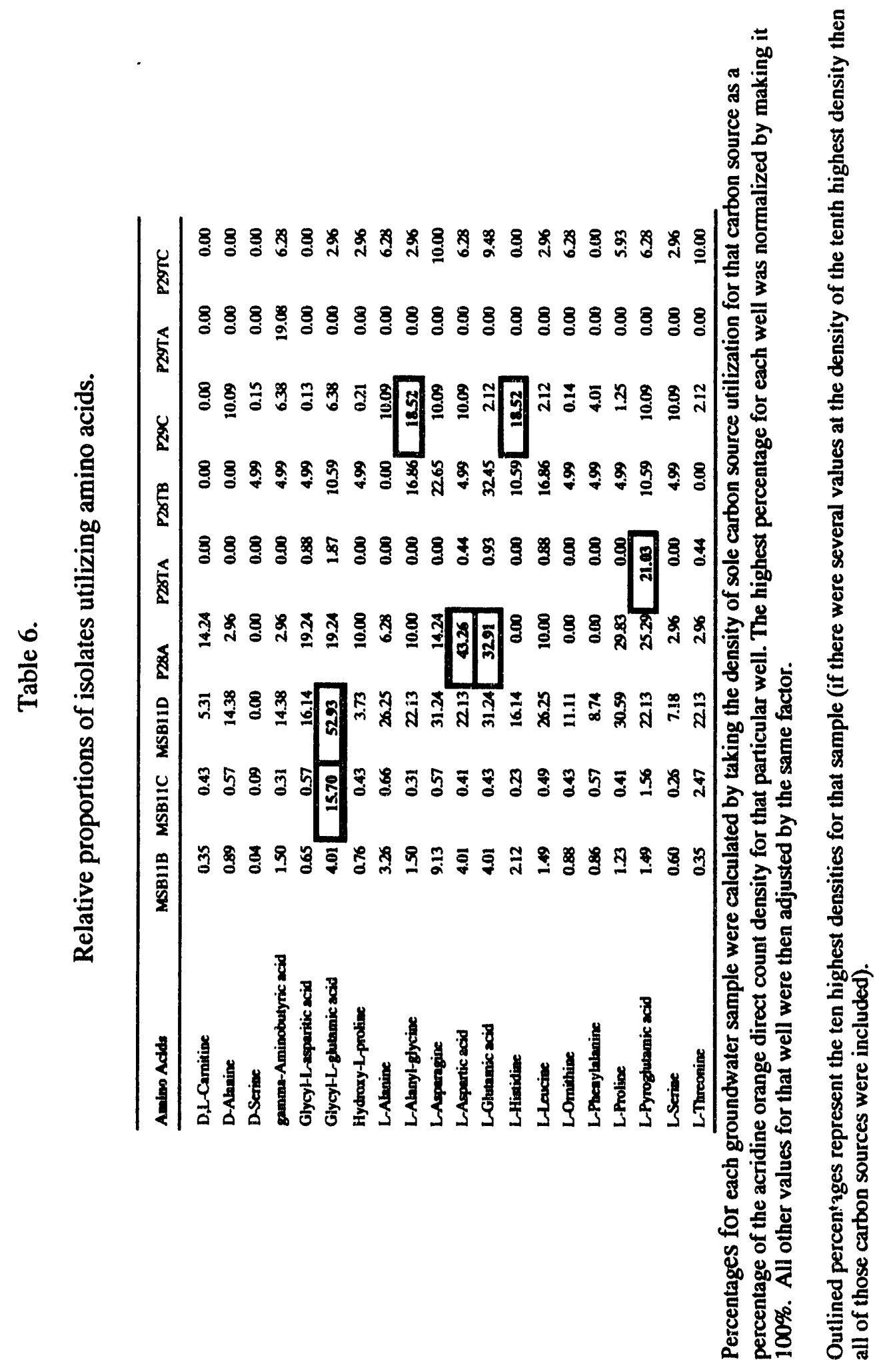




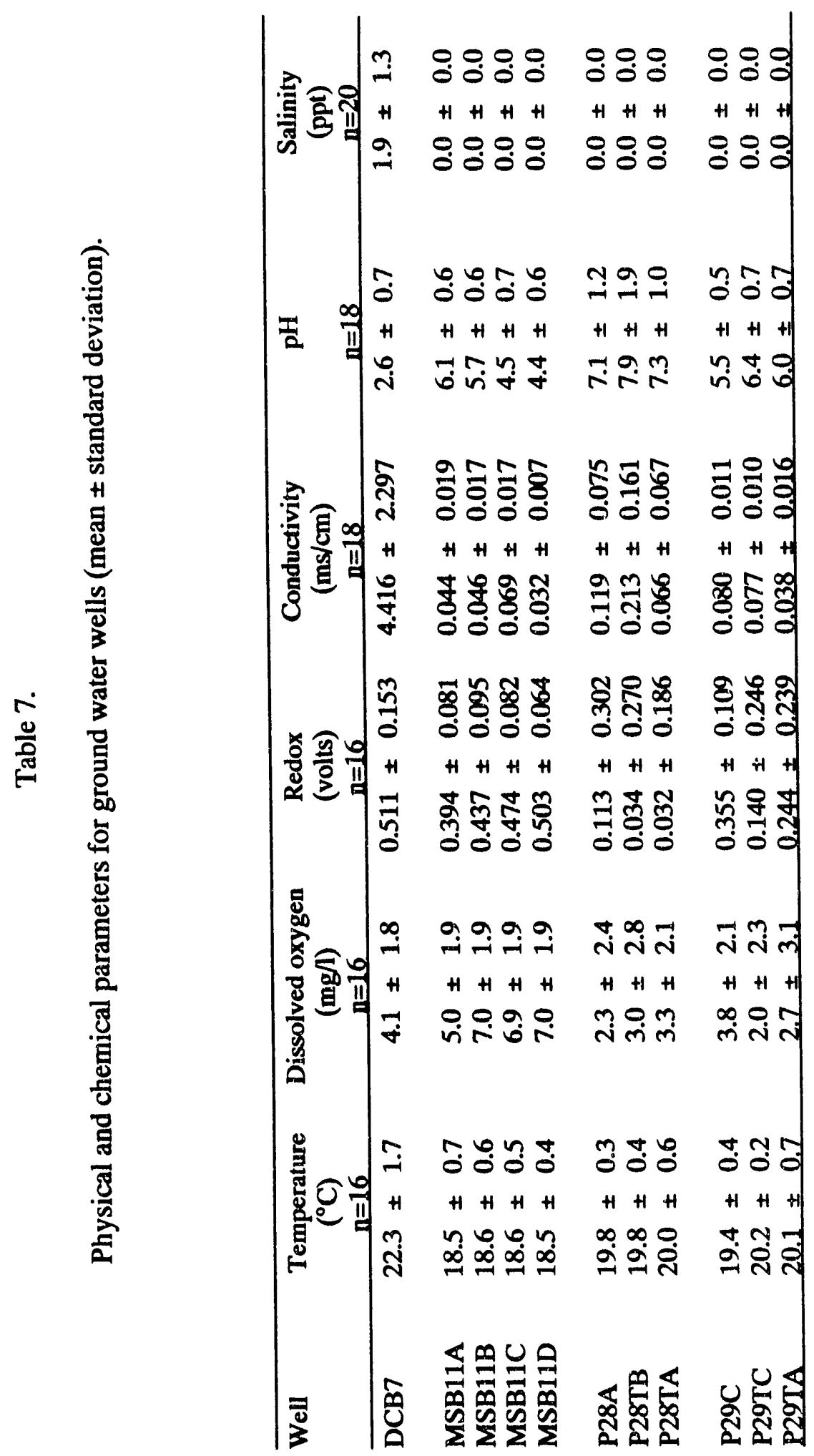


Table 8.

Aromatic compounds utilized by Pseudomonas putida mt-2

\begin{tabular}{lc}
\hline p-Coumarate & $+\mathrm{a}$ \\
Ferulate & + \\
Isovanillate & - \\
Phenol & - \\
Salicylate & + \\
m-Toluate & + \\
\hline
\end{tabular}

a Positive values represent enrichment tubes in which dissapearance of the aromatic substrate occurred. 


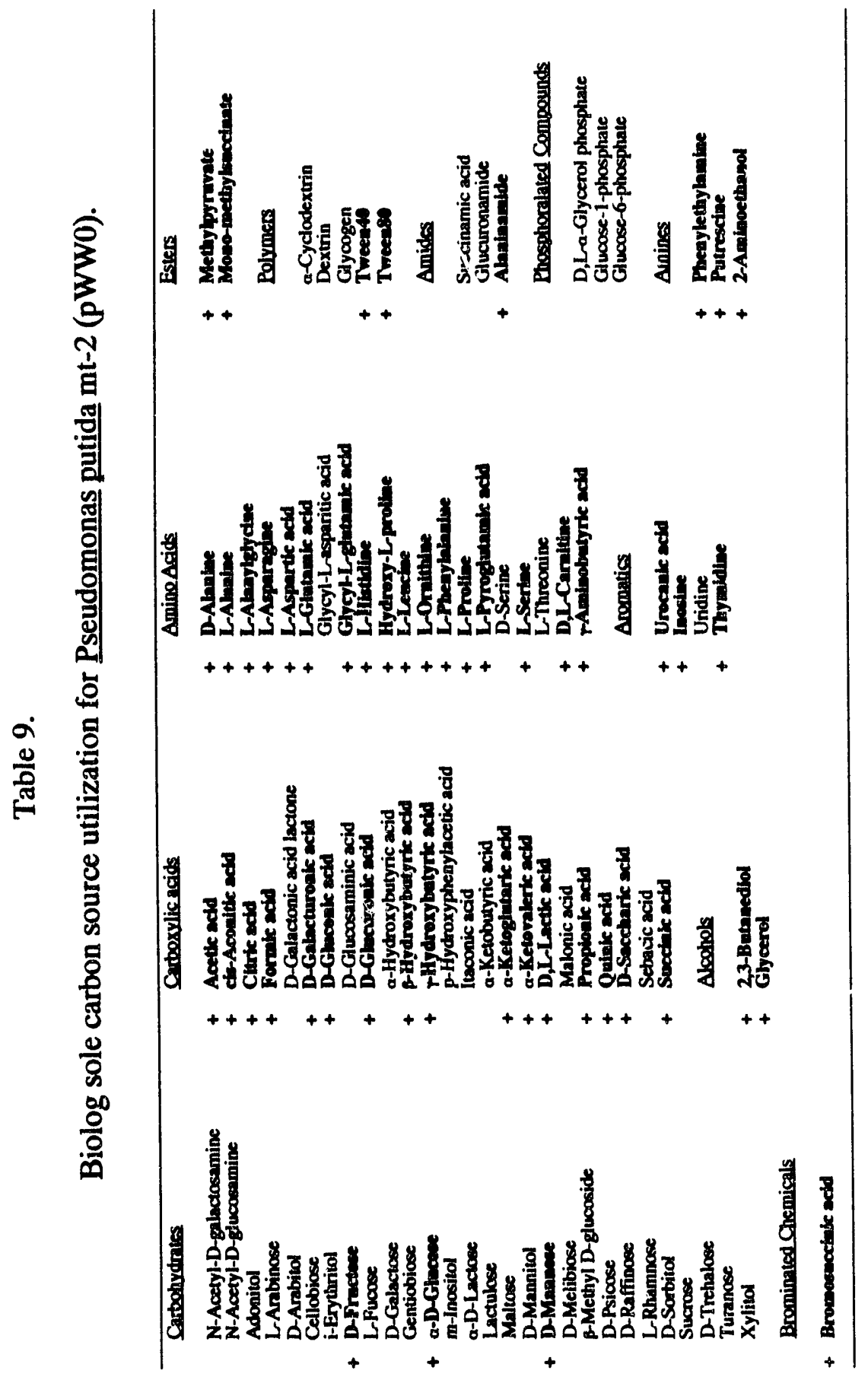


Table 10.

Carbohydrates commonly found associated with humic acid, humin and fulvic acid and the relative proportion each makes up of the total carbohydrates (Uzaki and Ishwatari, 1983).

\begin{tabular}{ll}
\hline Glucose & $31.9 \%$ \\
Galactose & $16.7 \%$ \\
Mannose & $15.4 \%$ \\
Xylose & $9.5 \%$ \\
Arabinose & $7.8 \%$ \\
Ribose & $1.7 \%$ \\
Fucose & $6.1 \%$ \\
Rhamnose & $9.2 \%$ \\
\hline
\end{tabular}


Table 11.

Carbohydrates giving greatest density in the pristine wells. These compounds are the carbohydrates giving the greatest density of 28 carbohydrates tested for each of the wells.

\begin{tabular}{ll}
\hline Well & Carbon Source \\
\hline P28A & a-D-Glucose \\
P28TB & L-Arabinose \\
P28TA & L-Arabinose \\
& \\
P29C & L-Fucose \\
P29TC & L-Arabinose \\
P29TA & L-Arabinose \\
\hline
\end{tabular}


Table 12.

API-NFT results for isolates taken from three of the MSB cluster wells. Fifty isolates were taken at random 1\% PTYG and 50 isolates were taken randomly from PTYG for each of the wells. These results represent the pooled results from PTYG and $1 \%$ PTYG for each well.

\begin{tabular}{lccc}
\hline Well & $\begin{array}{l}\text { MSB11B } \\
\text { \% Positive }\end{array}$ & $\begin{array}{l}\text { MSB11C } \\
\% \text { Positive }\end{array}$ & $\begin{array}{l}\text { MSB11D } \\
\% \text { Positive }\end{array}$ \\
\hline Gram negative & 96 & 84 & 89 \\
Nitrate reduction & 6 & 27 & 44 \\
Tryptophanase & 0 & 0 & 2 \\
Glucose fermentation & 0 & 0 & 0 \\
Arginine dihydrolase & 0 & 0 & 0 \\
Urease & 12 & 36 & 18 \\
Esculin hydrolysis & 52 & 49 & 47 \\
Gelatinase & 28 & 2 & 0 \\
$\beta$-Galactosidase & 74 & 33 & 36 \\
Oxidase & 14 & 31 & 29 \\
\hline
\end{tabular}


Table 13.

API-NFT results and Gram stain reaction for isolates taken from PTYG and 1\%

PTYG. Fifty isolates were taken at random from 1\% PTYG agar plates and 50

isolates were taken randomly from PTYG agar plates from wells MSB11B, MSB11C, and MSB11D. These results represent the pooled results from all three wells.

\begin{tabular}{lcc}
\hline Media & $\begin{array}{c}\text { PTYG } \\
\text { \% Positive }\end{array}$ & $\begin{array}{c}\text { 1\% PTYG } \\
\% \text { Positive }\end{array}$ \\
\hline Gram negative & 88 & 92 \\
Nitrate reduction & 15 & 36 \\
Tryptophanase & 1 & 0 \\
Glucose fermentation & 0 & 0 \\
Arginine dihydrolase & 0 & 0 \\
Urease & 20 & 22 \\
Esculin hydrolysis & 34 & 63 \\
Gelatinase & 0 & 19 \\
$\beta$-galactosidase & 41 & 54 \\
Oxidase & 45 & 5 \\
\hline
\end{tabular}




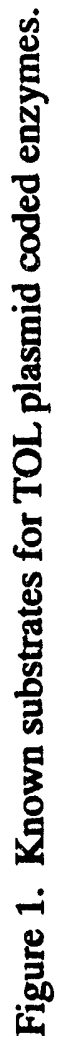



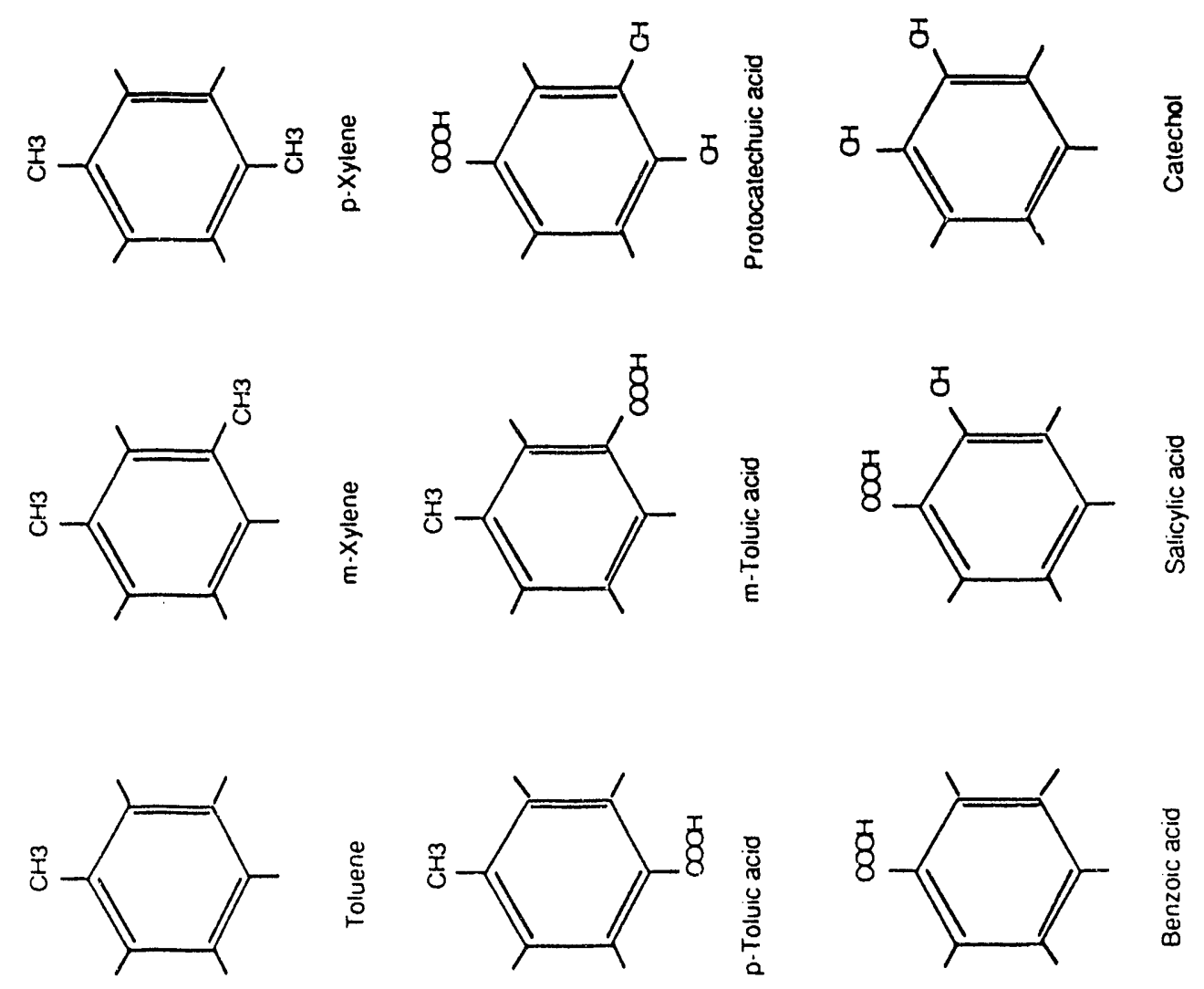


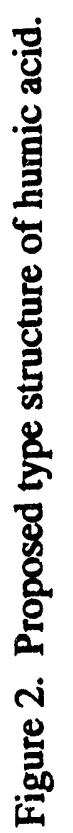




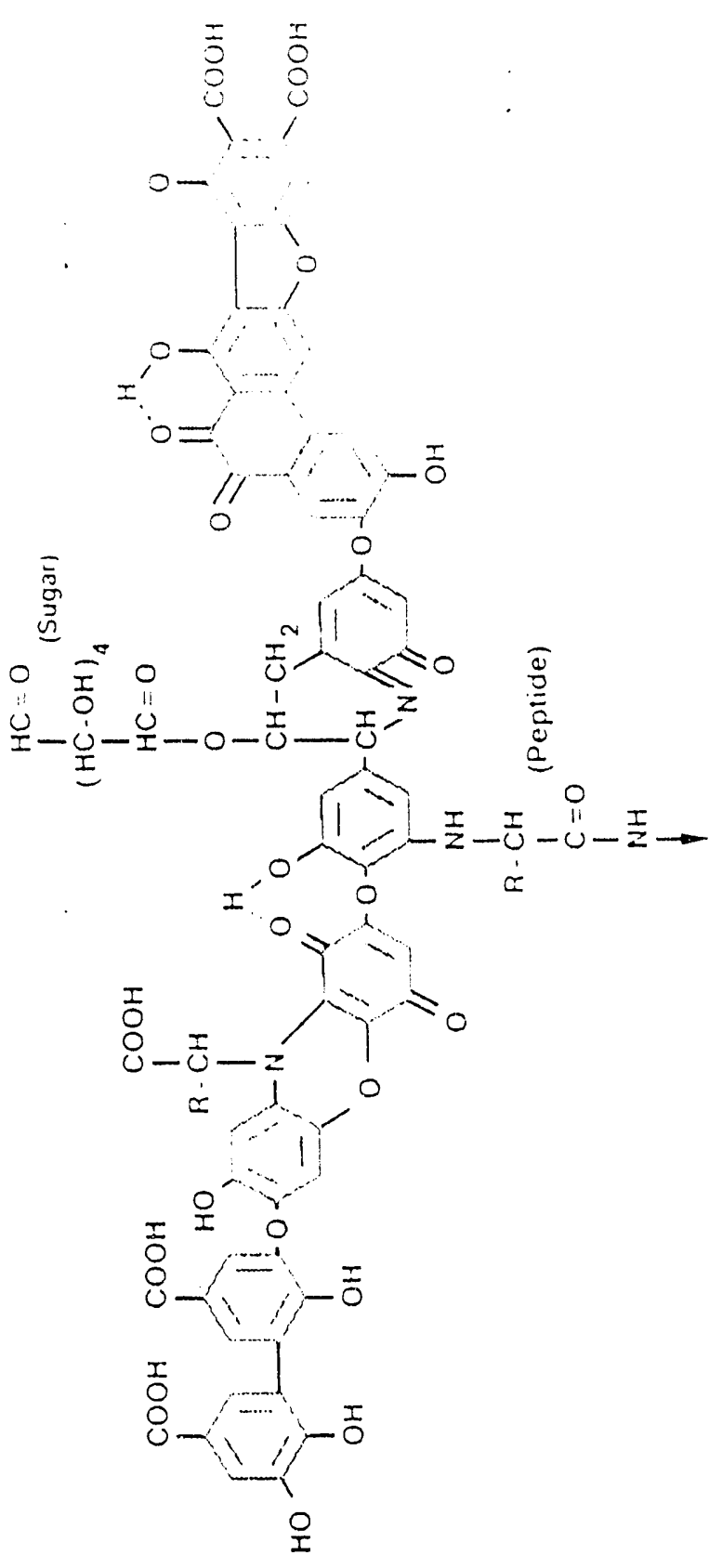




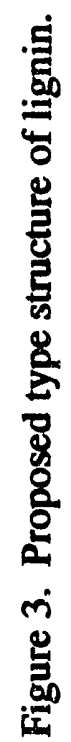




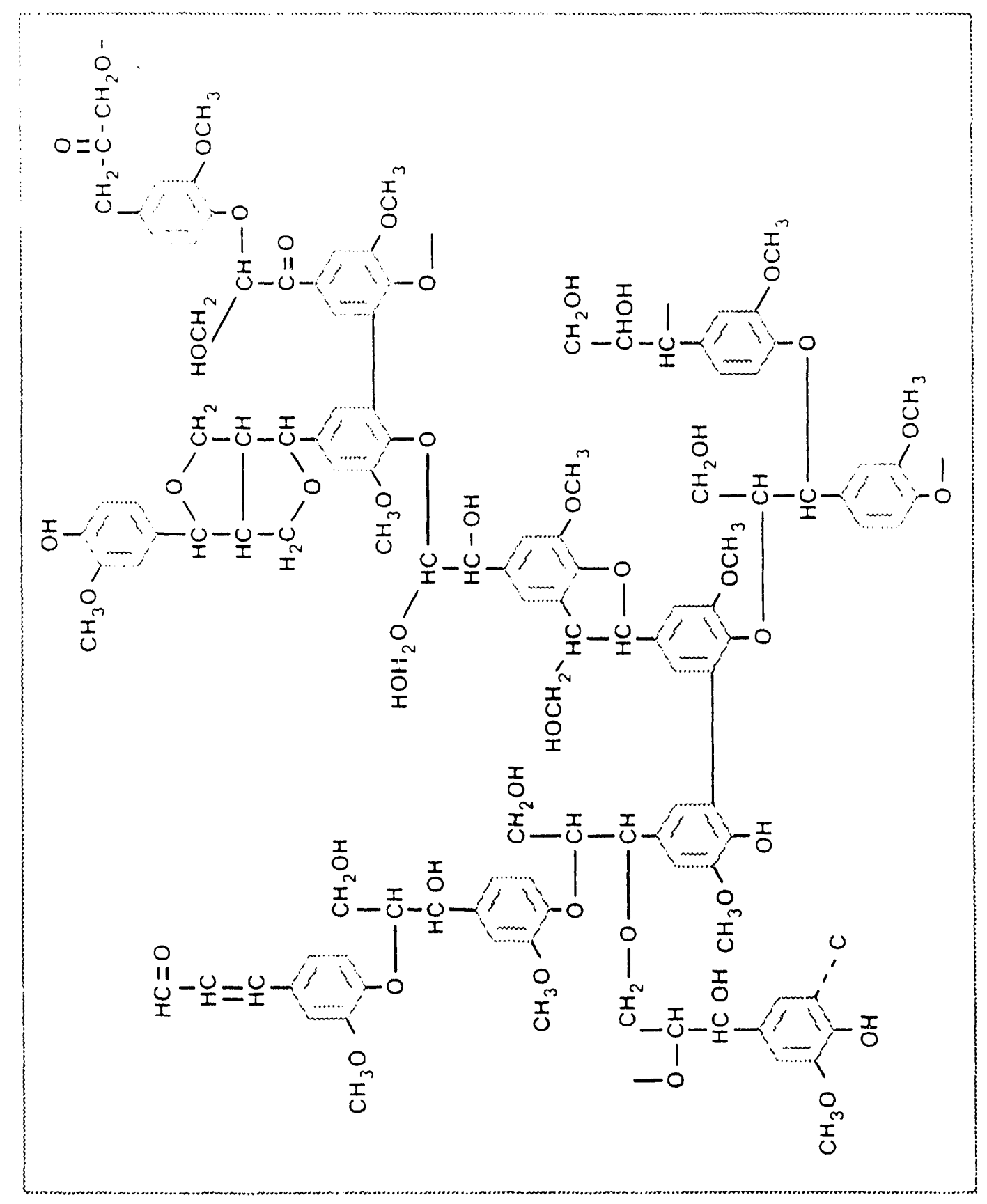




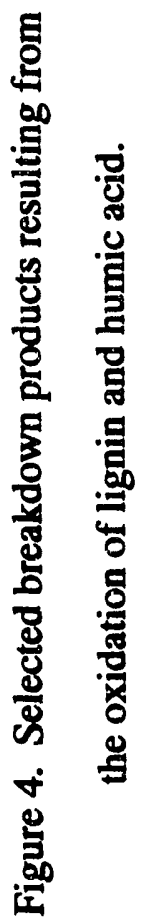



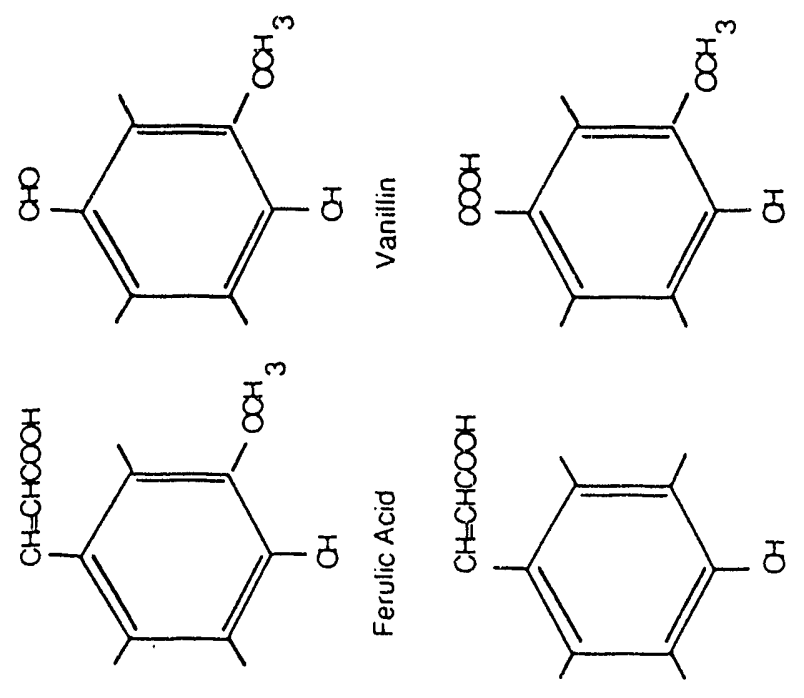

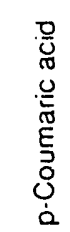

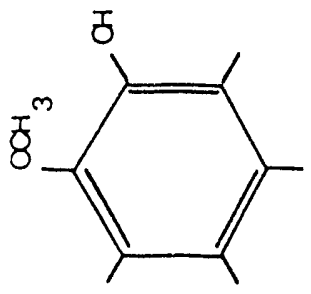

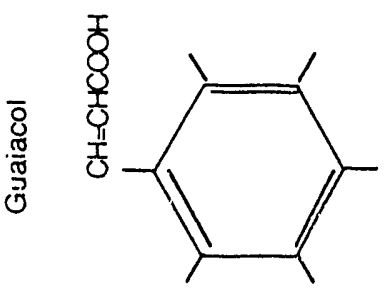

음
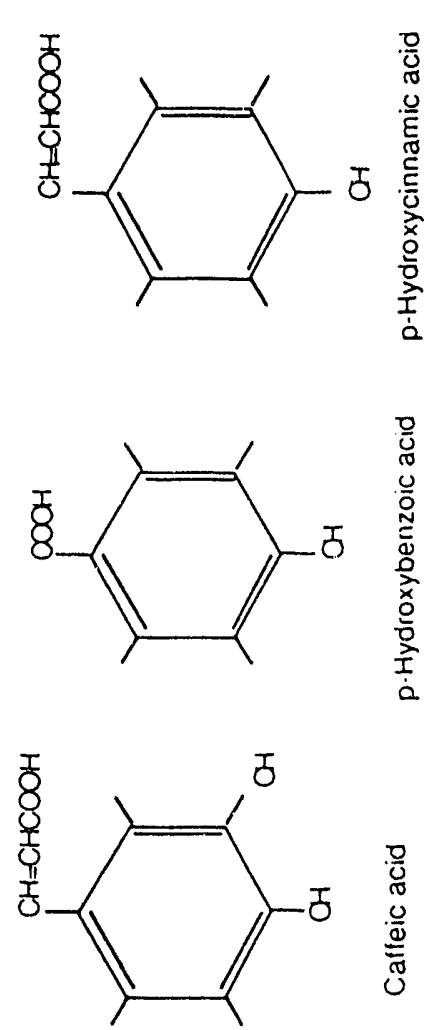


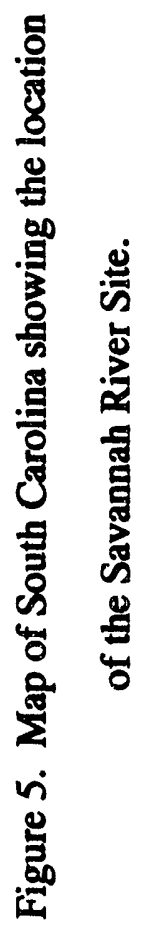




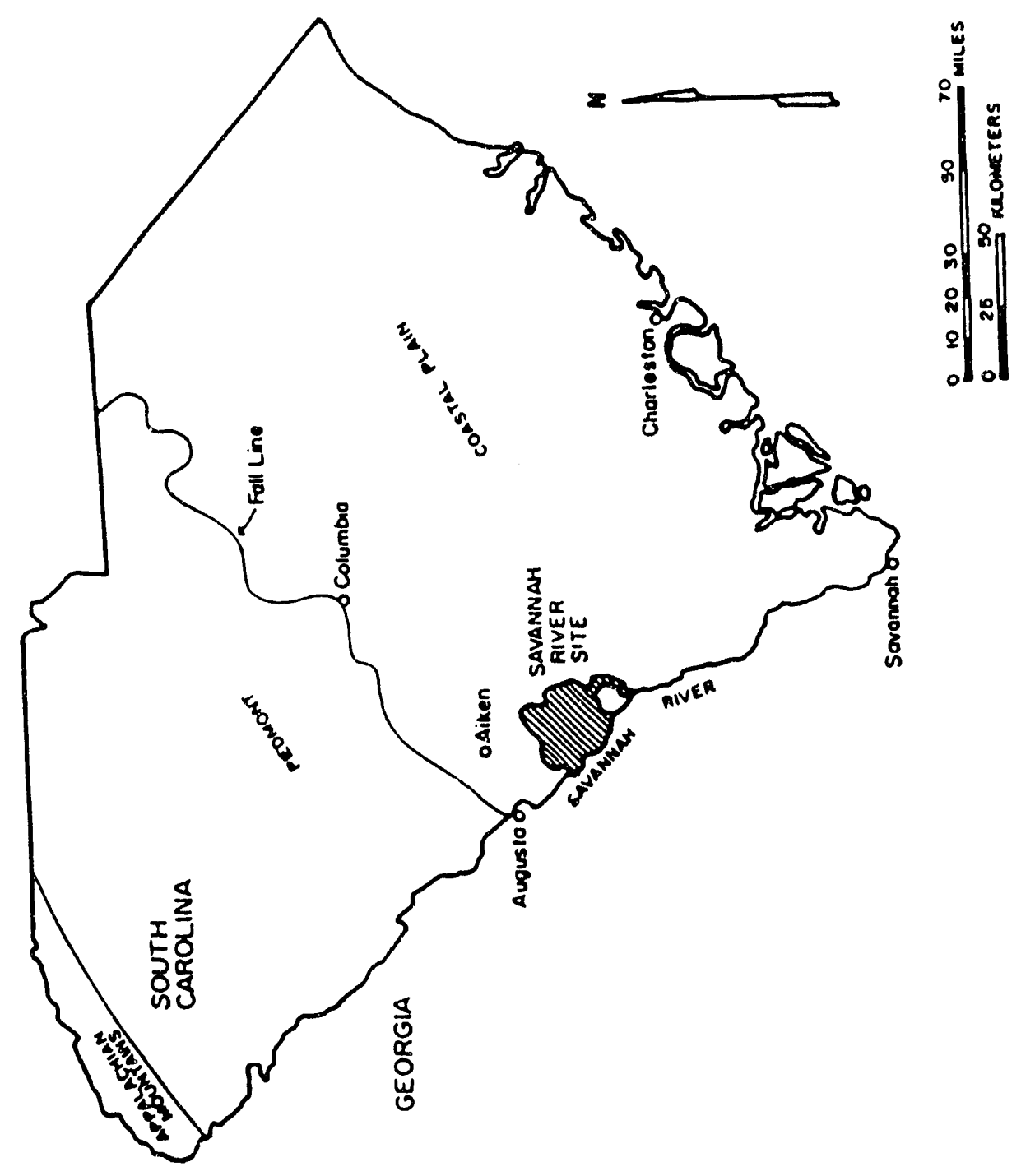




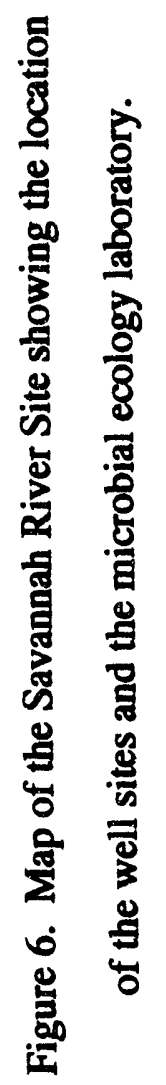




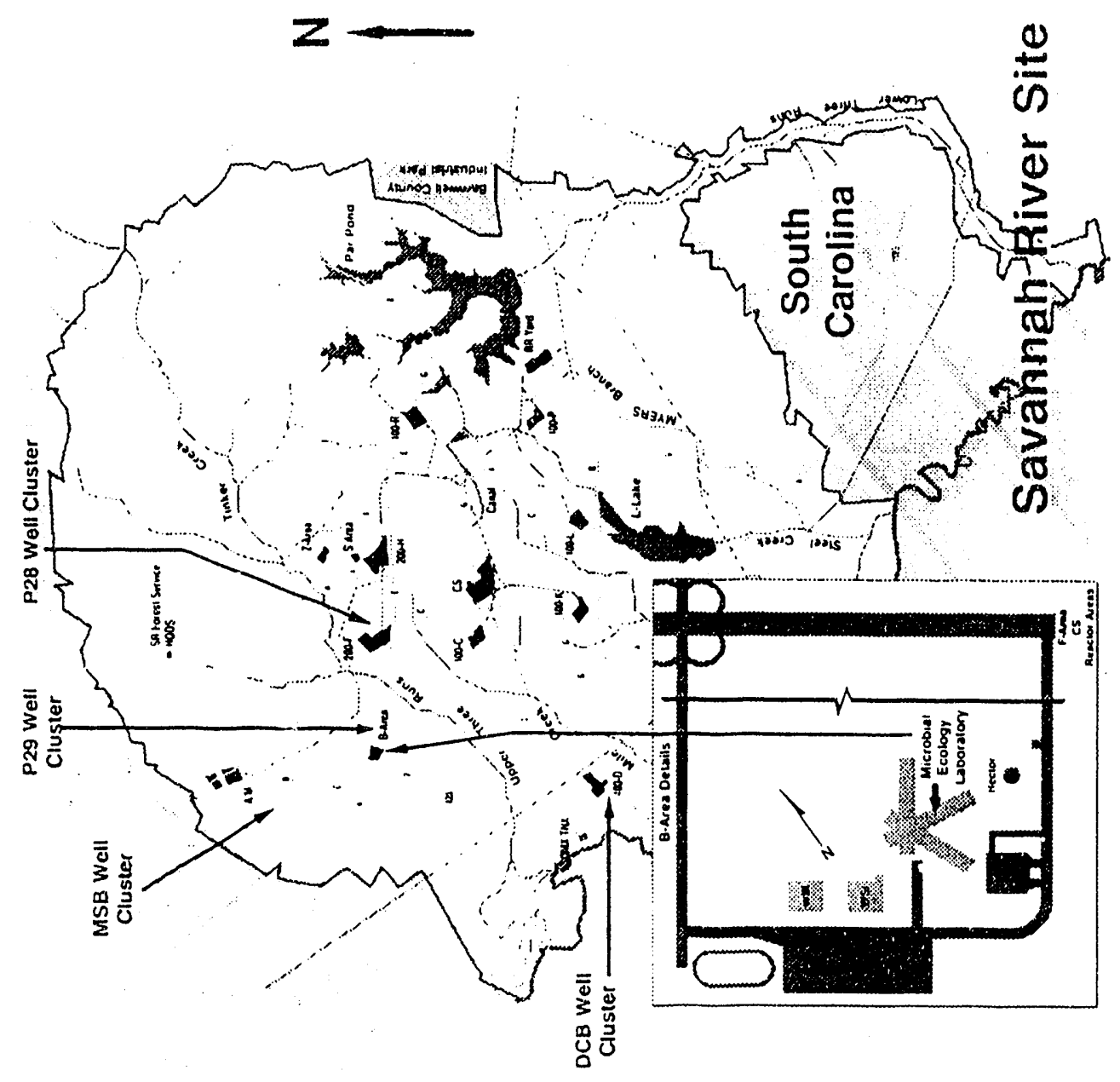




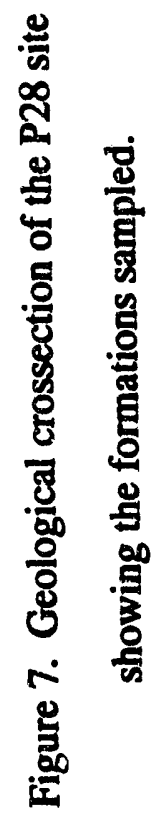




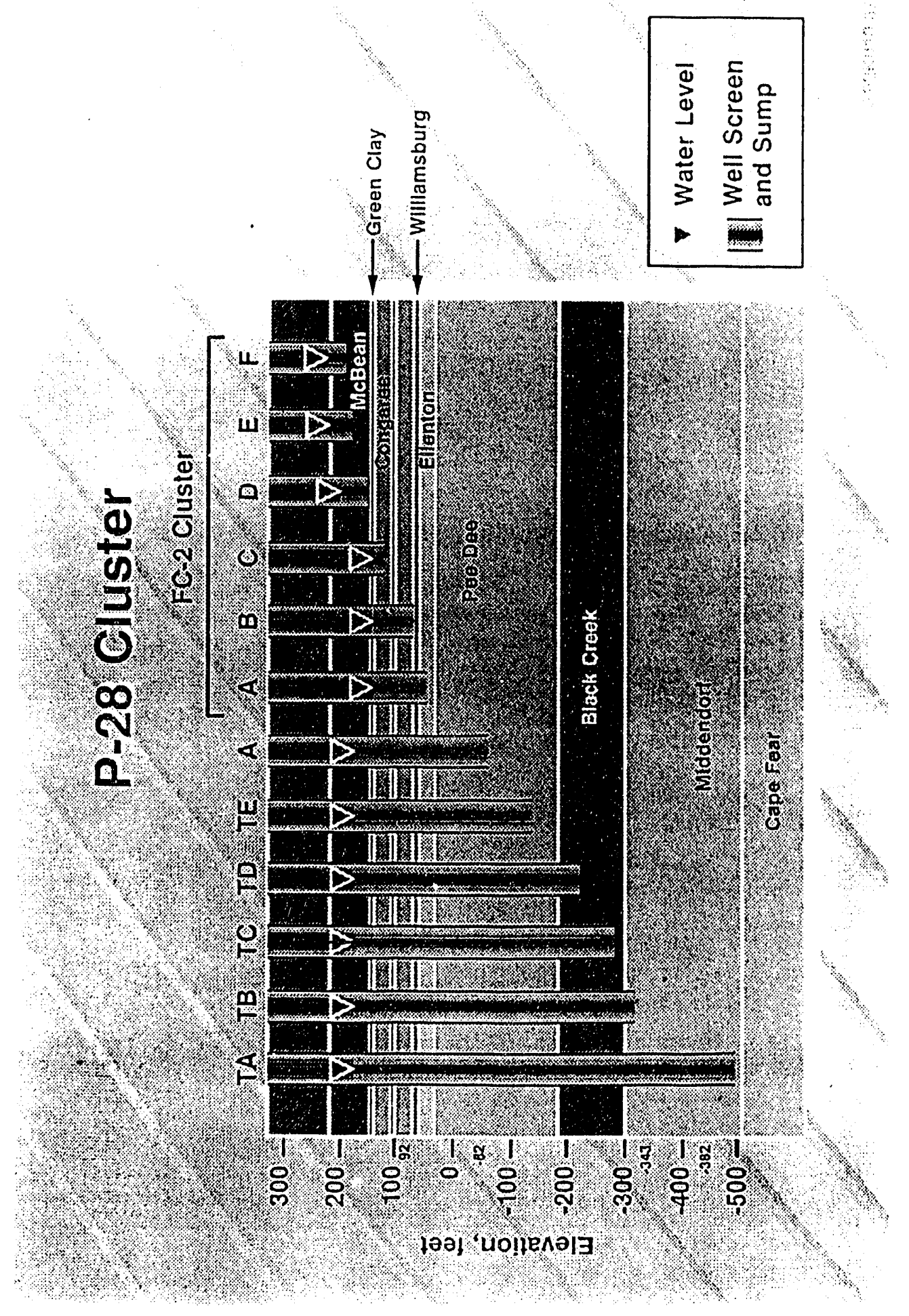


$\|$ 

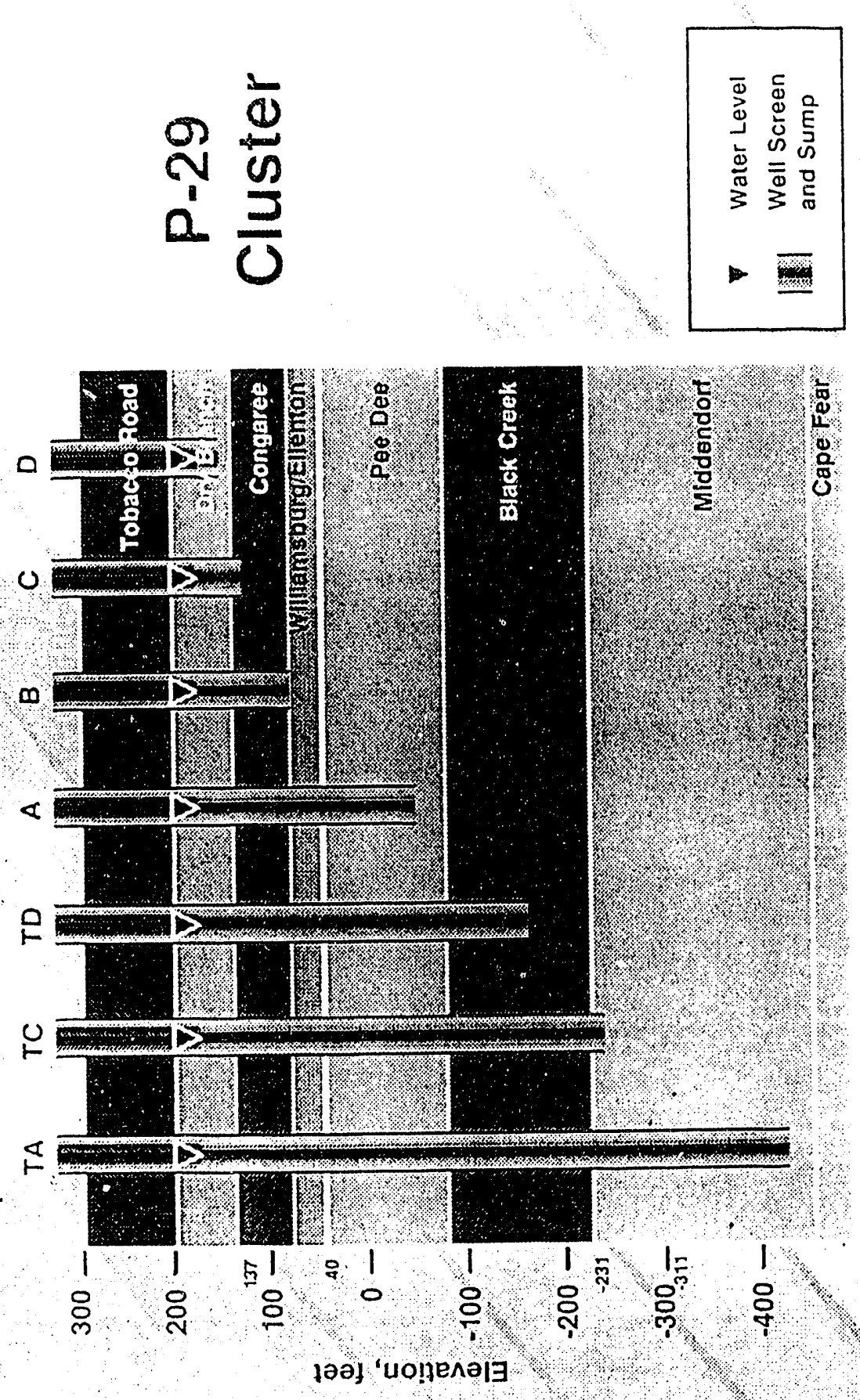


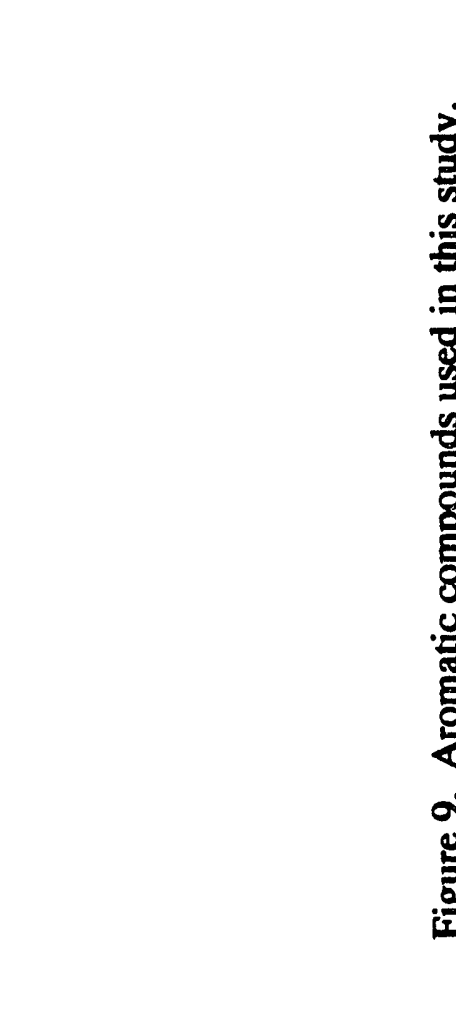



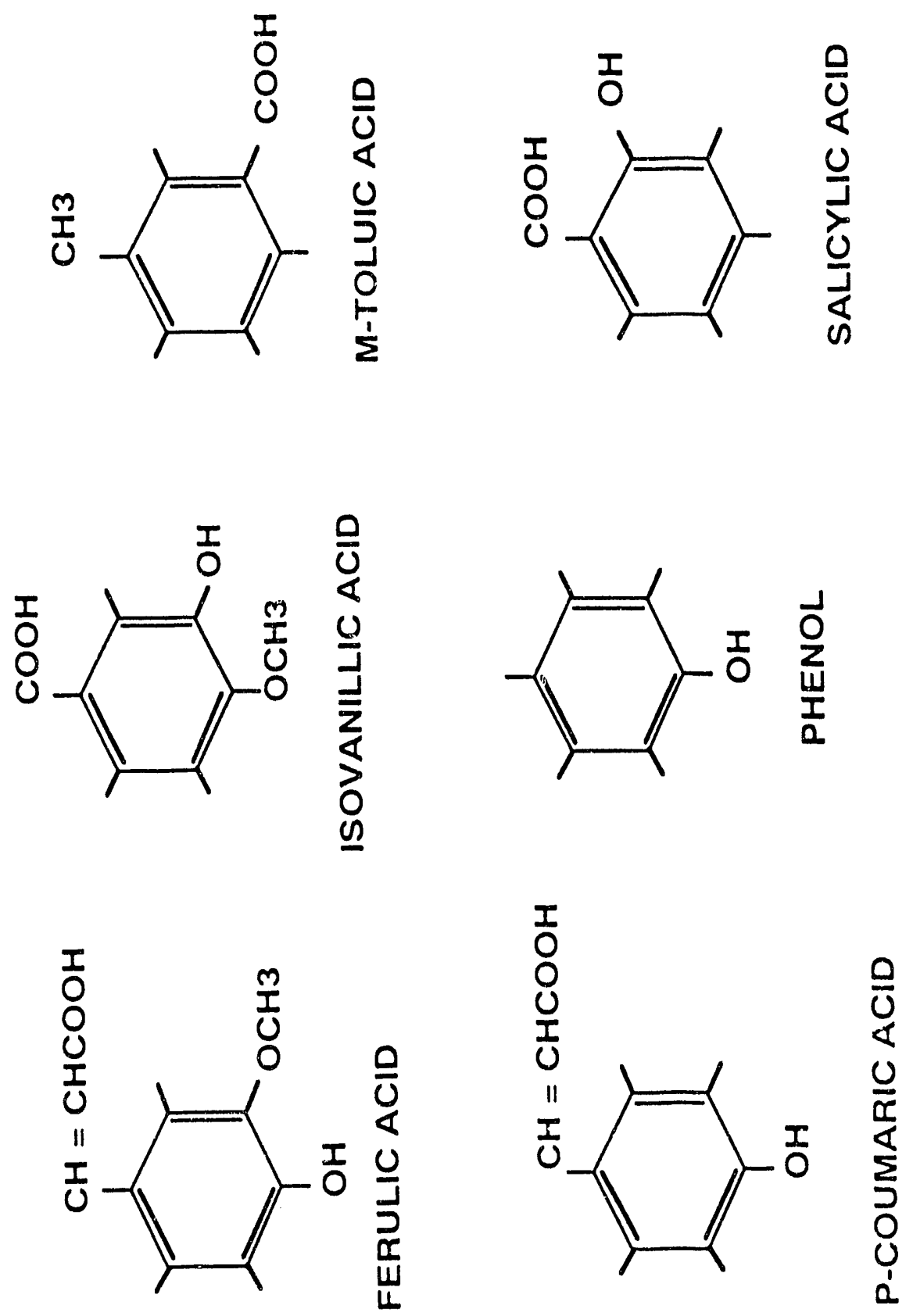


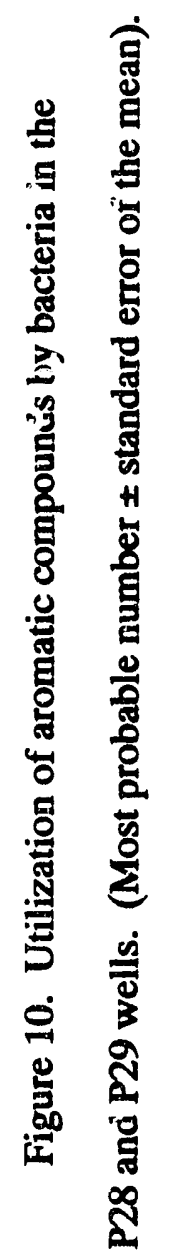




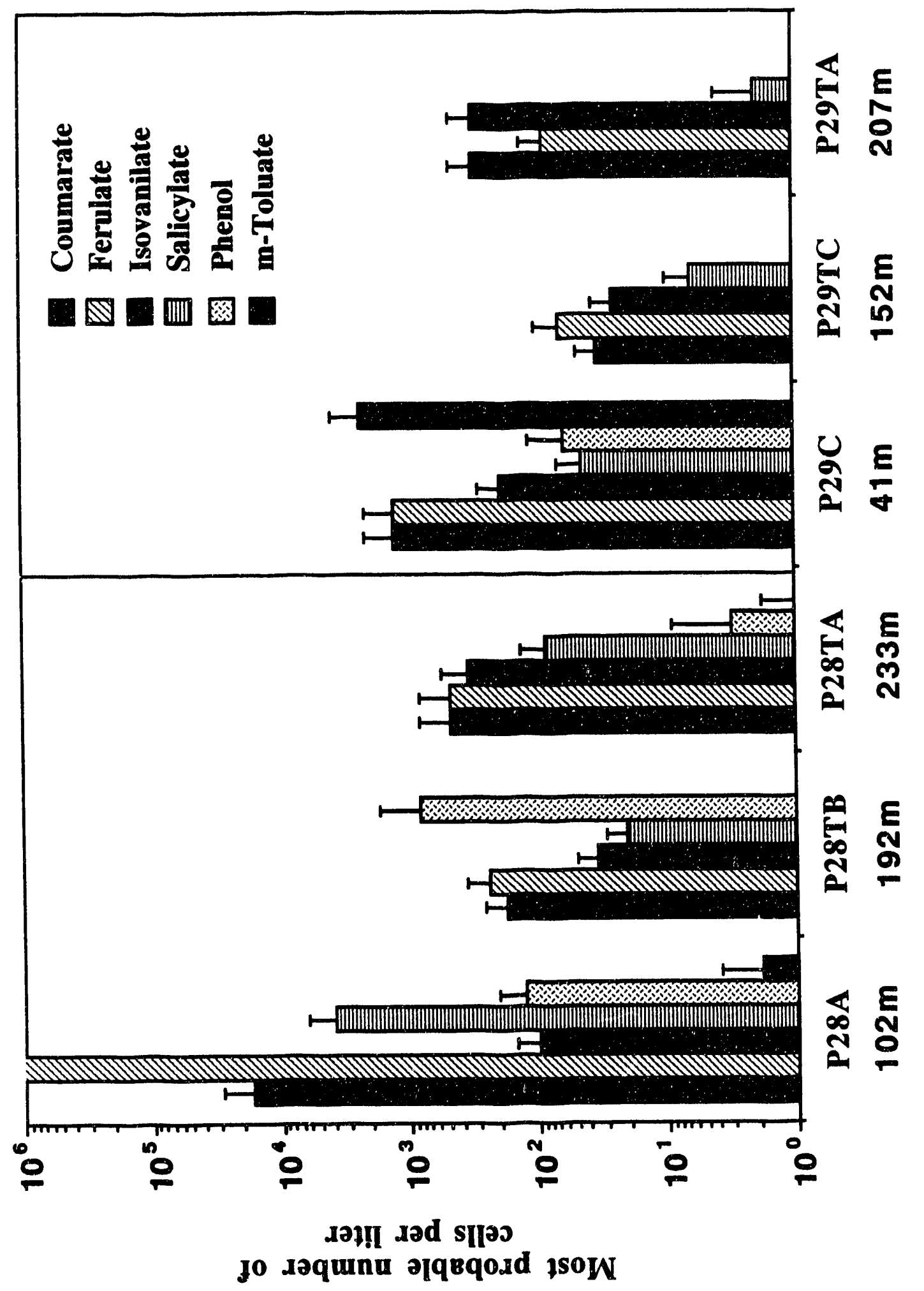




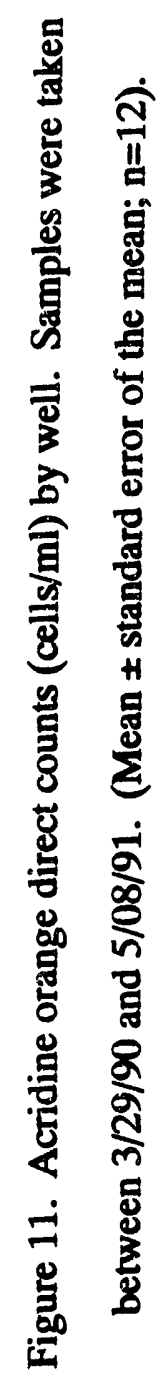




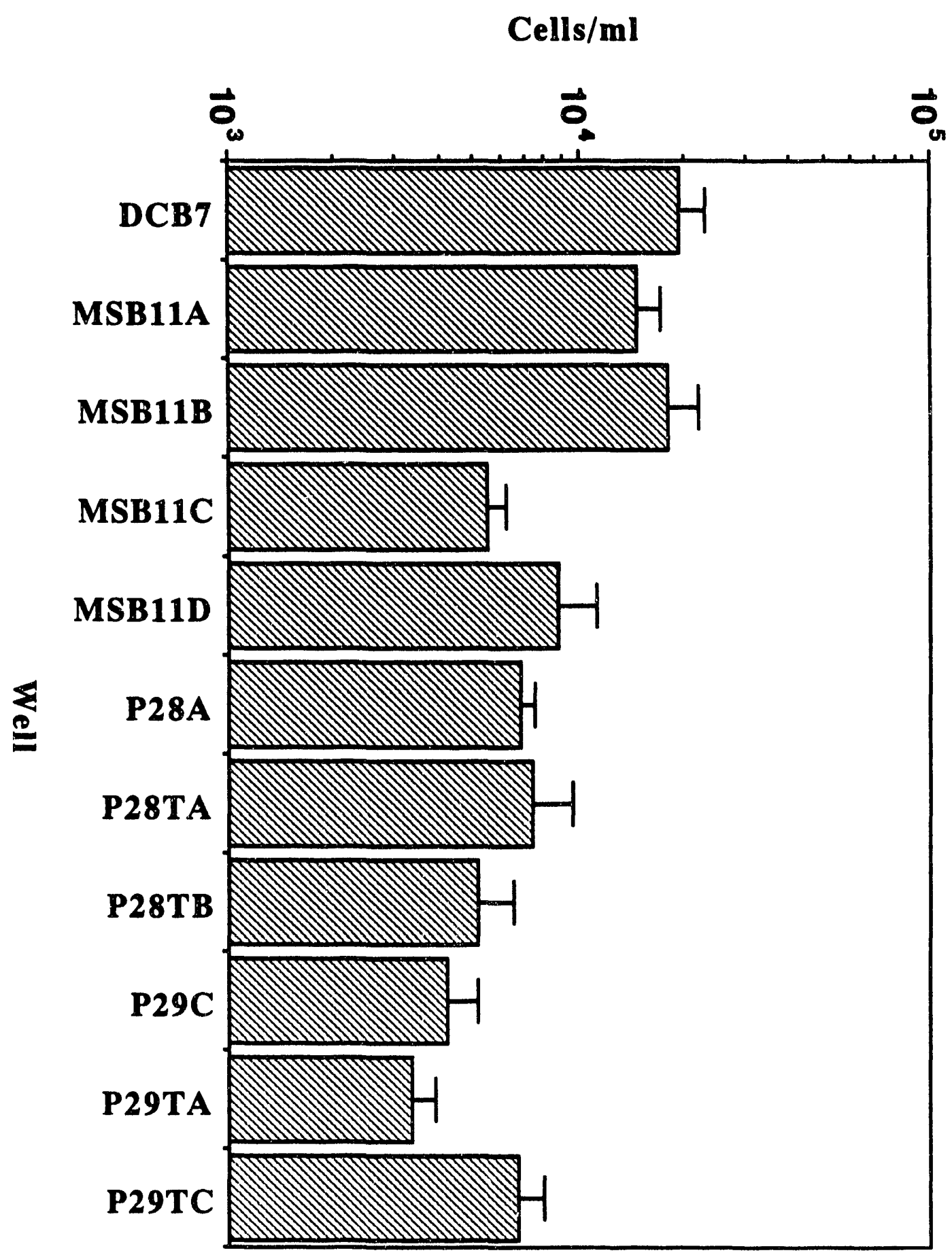




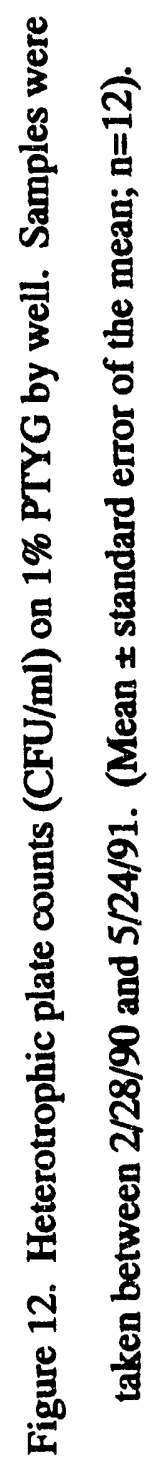




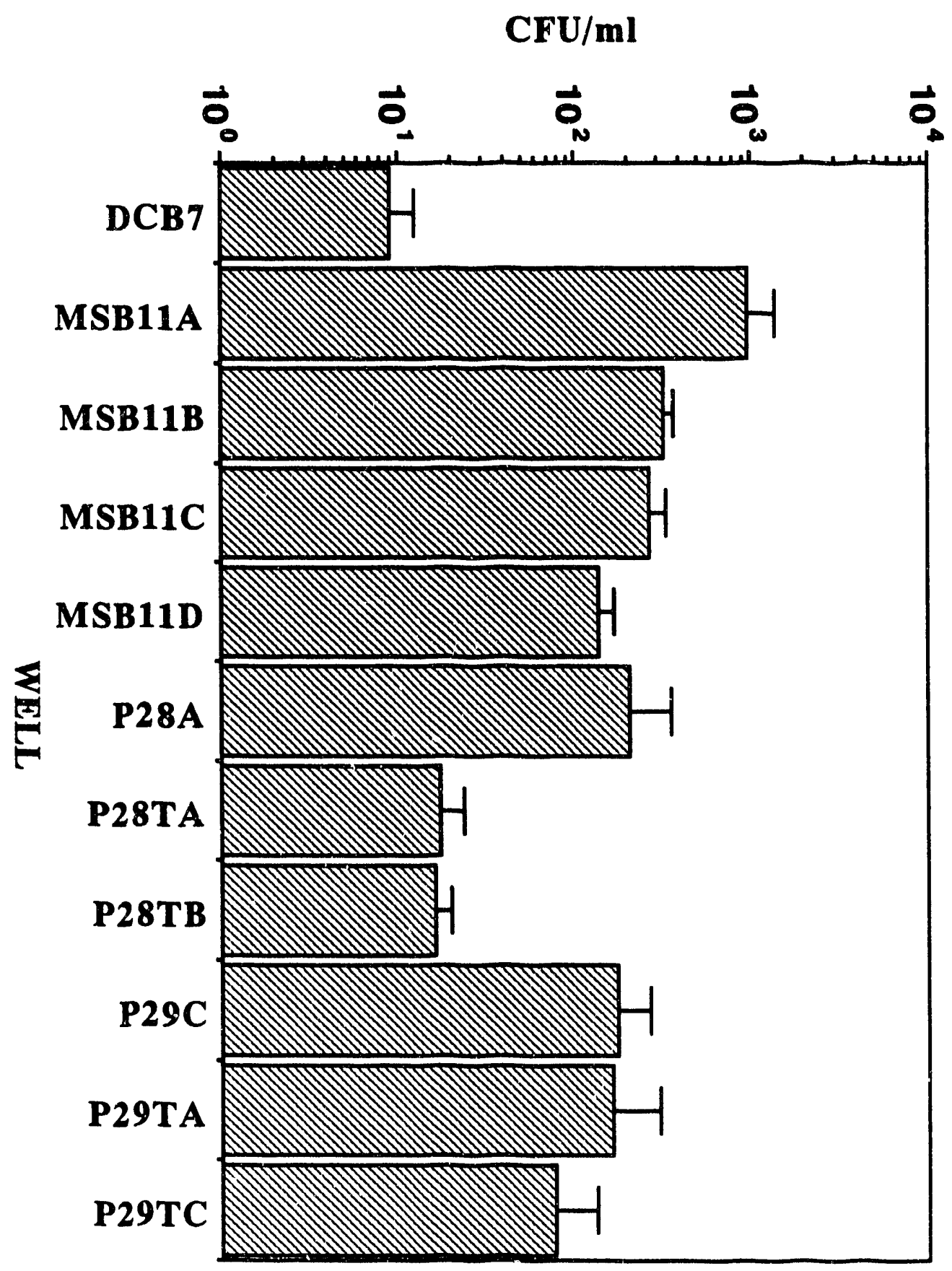




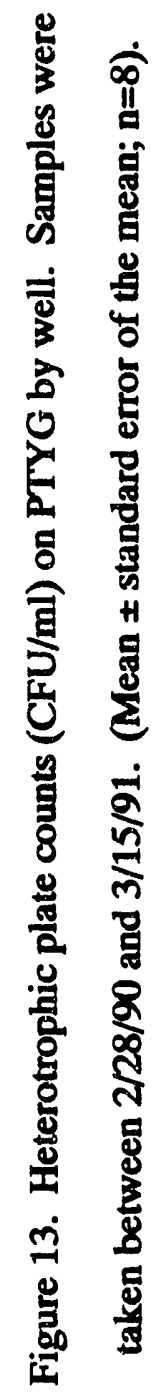




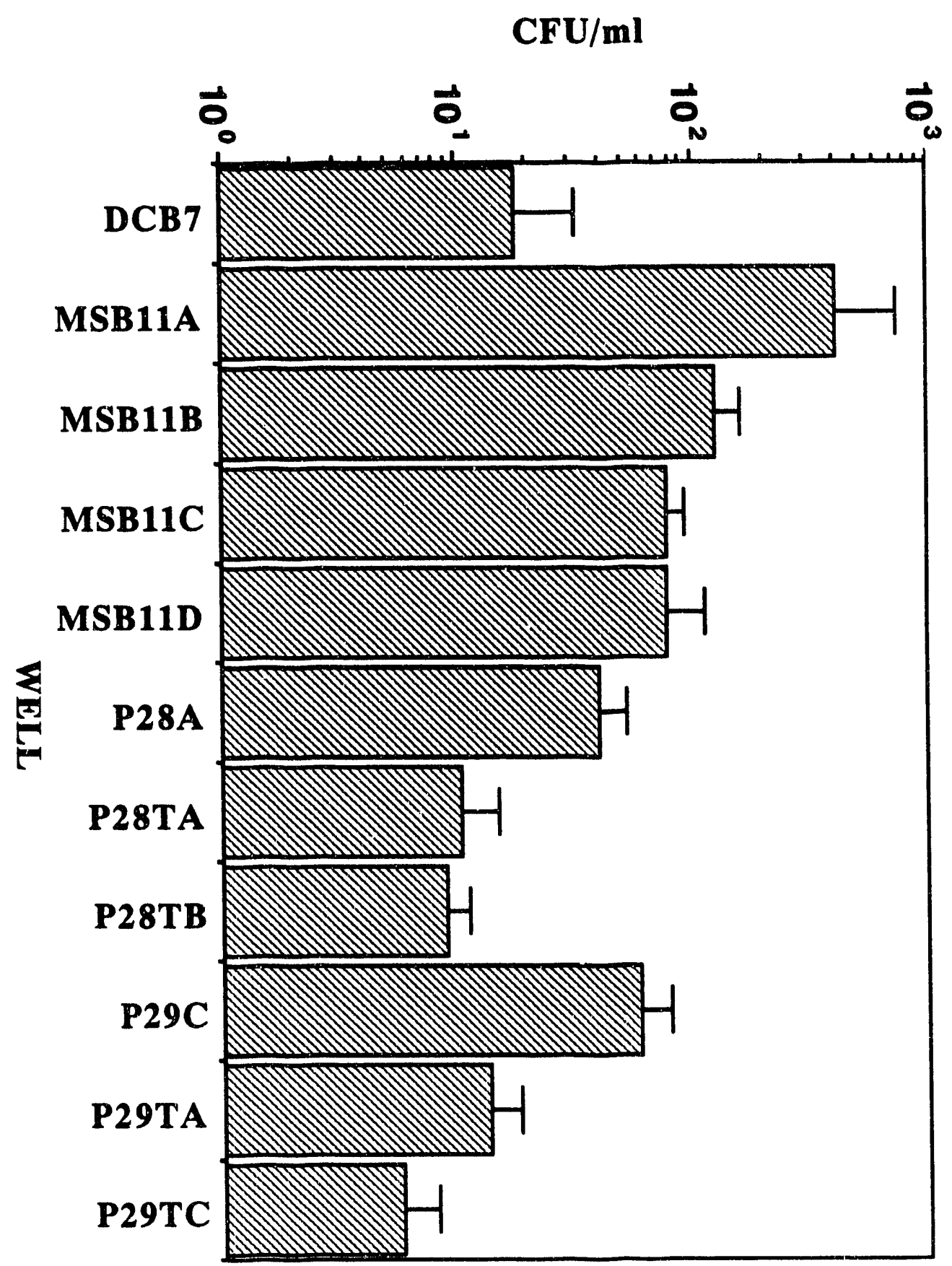




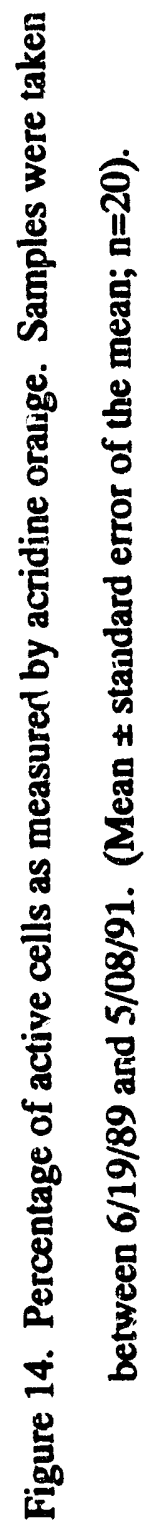




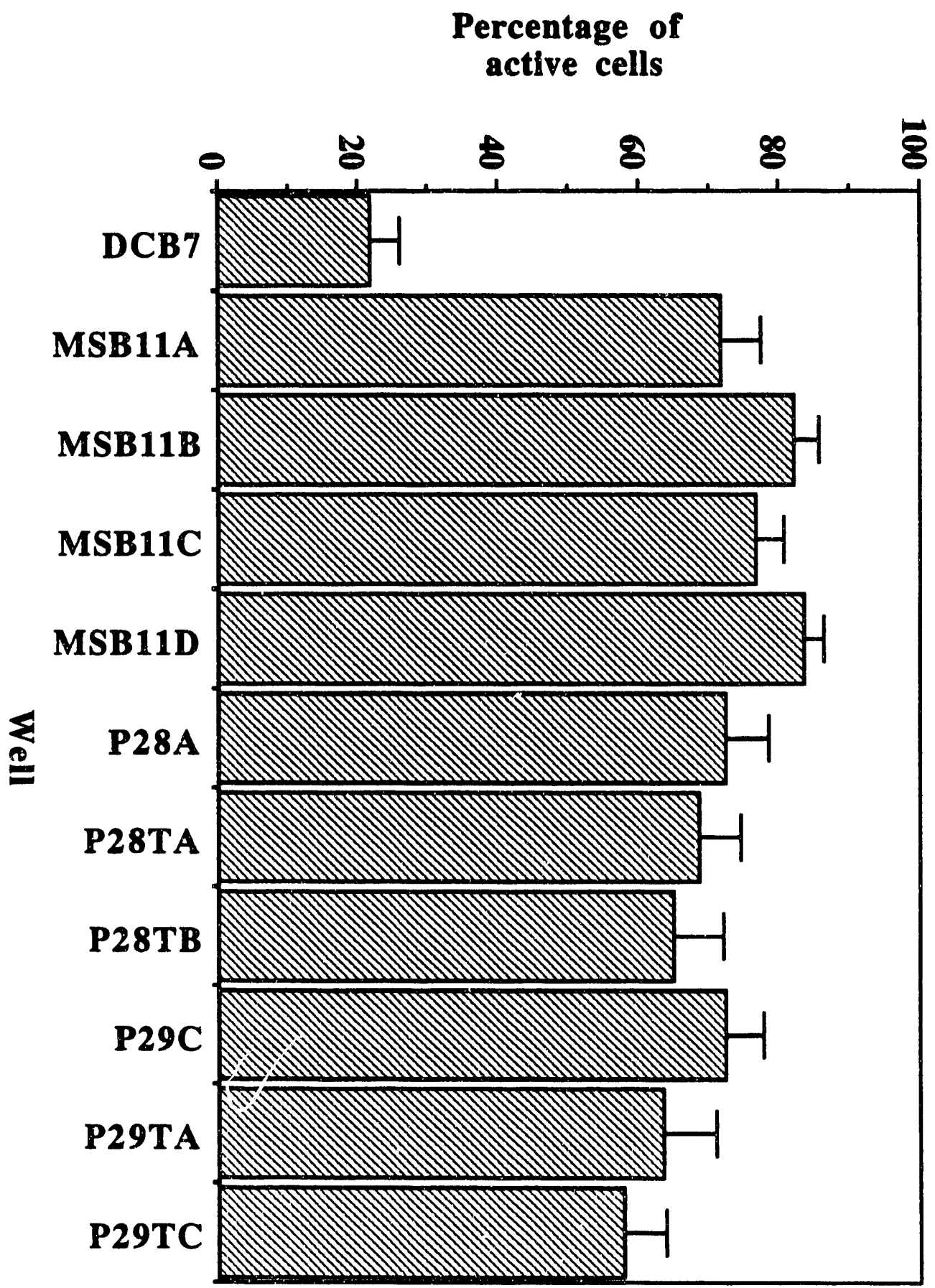




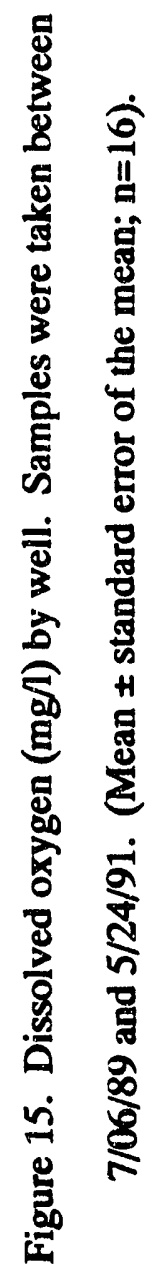




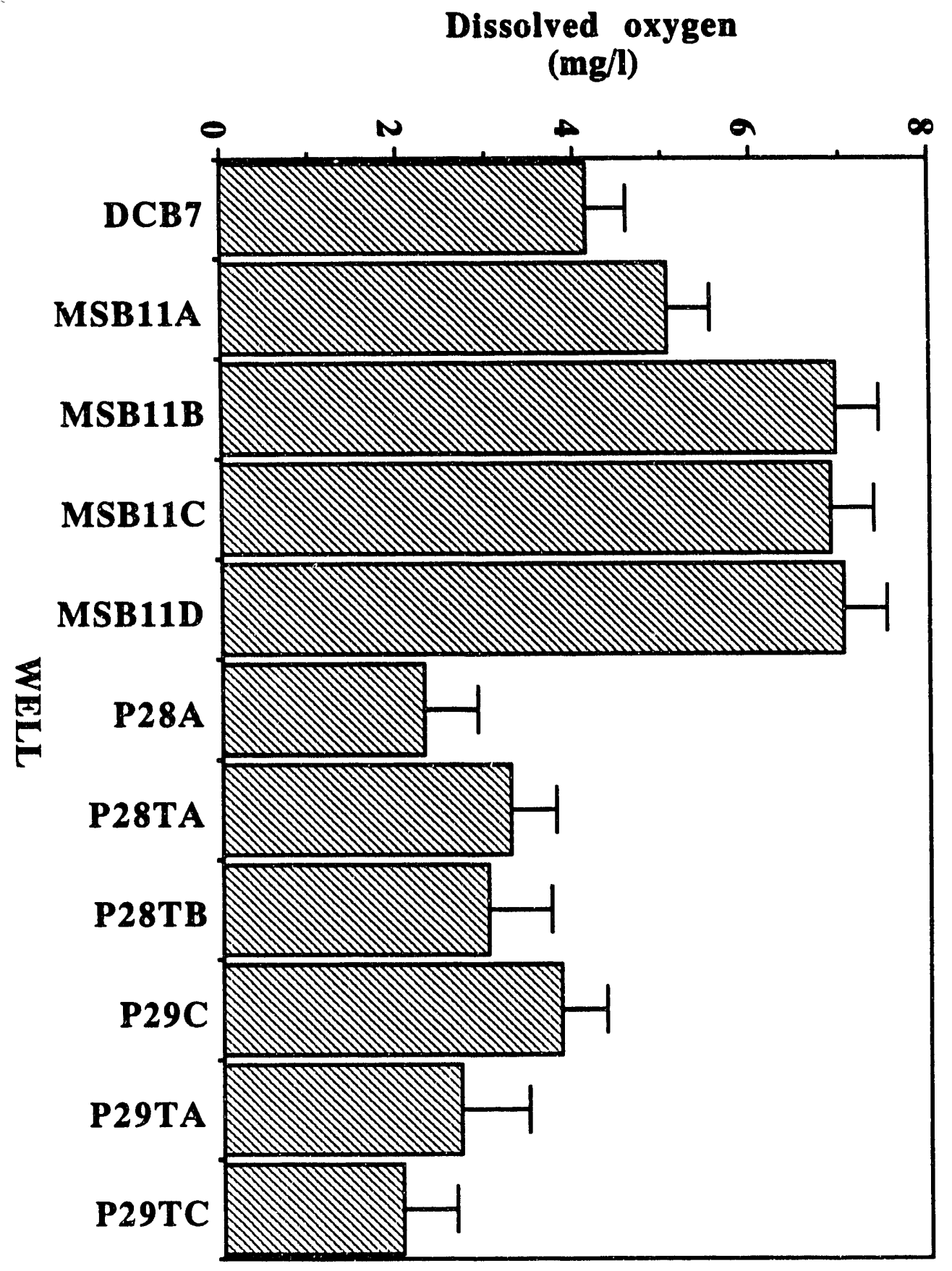




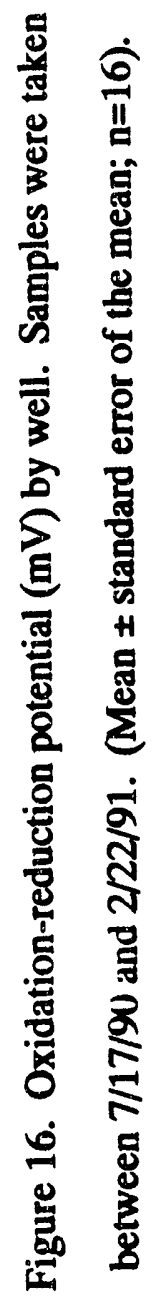




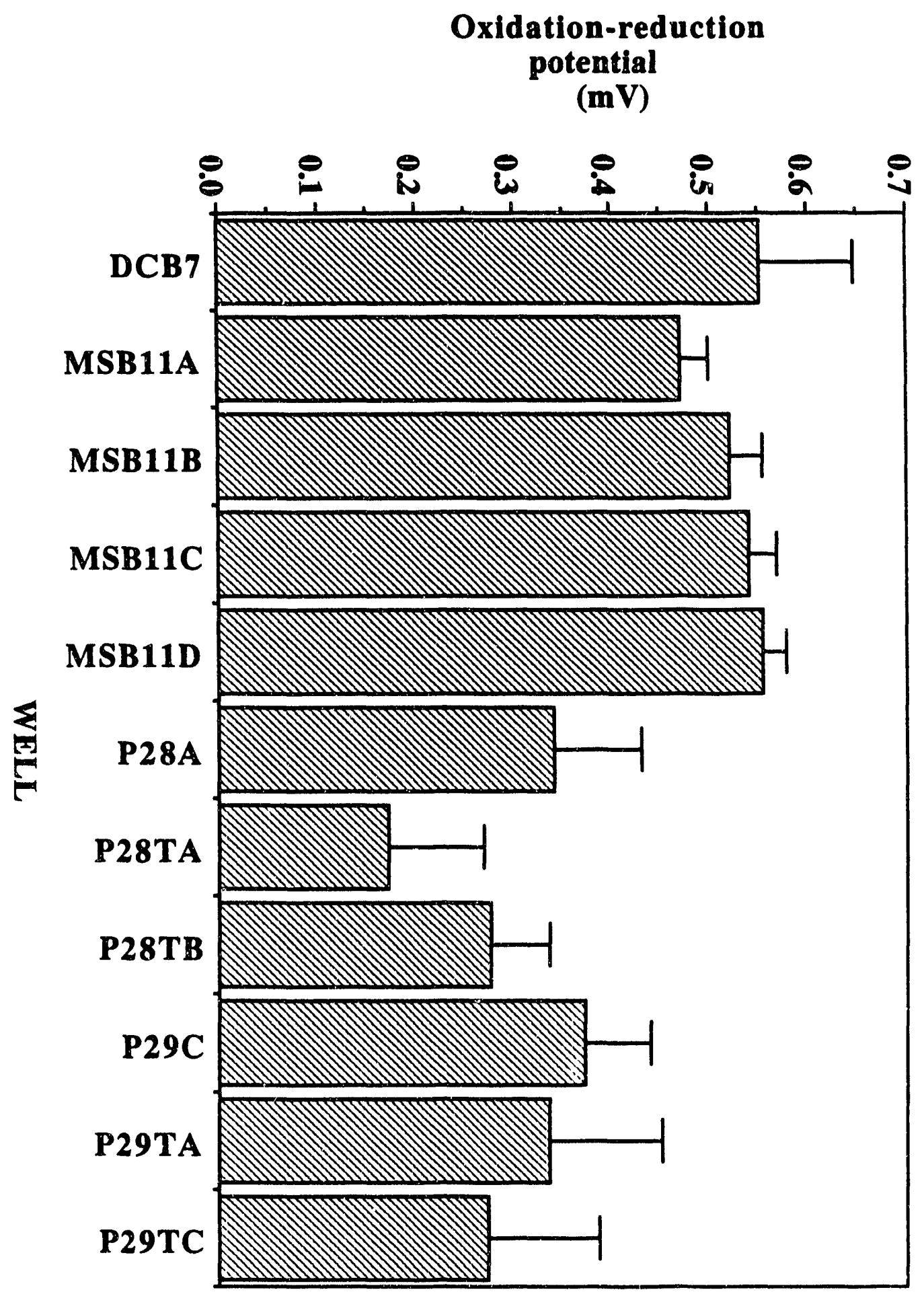




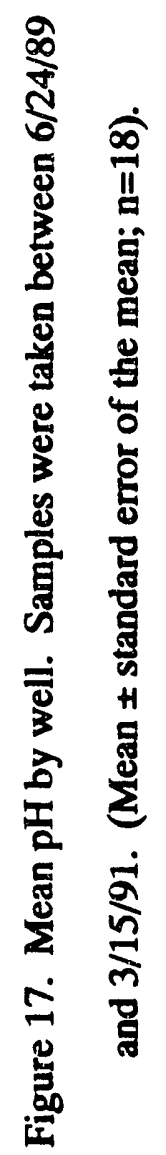




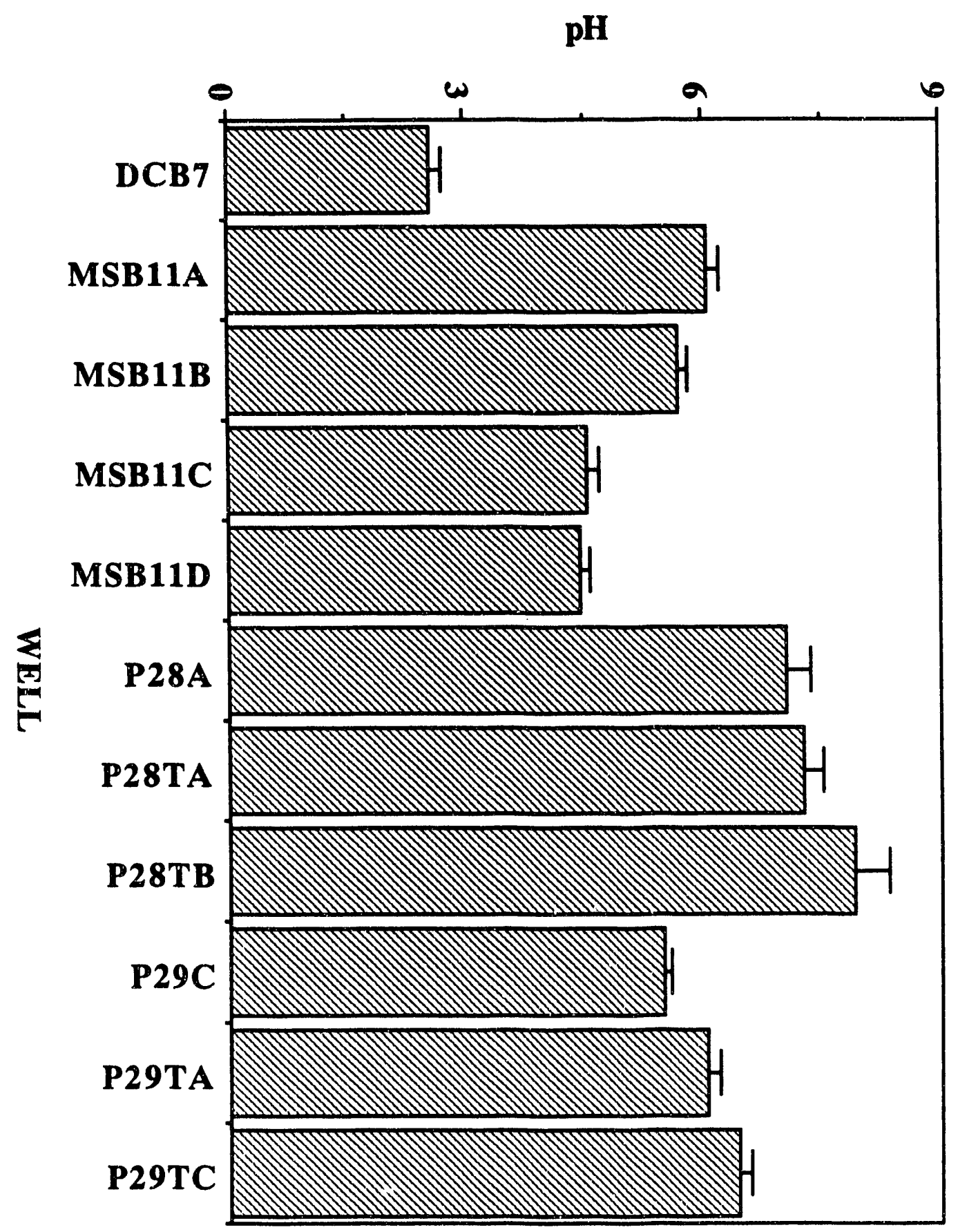




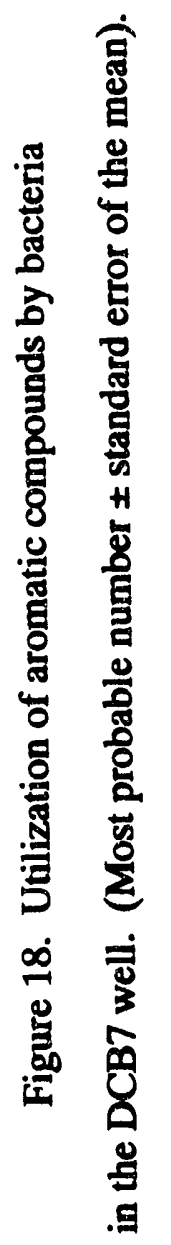

112 


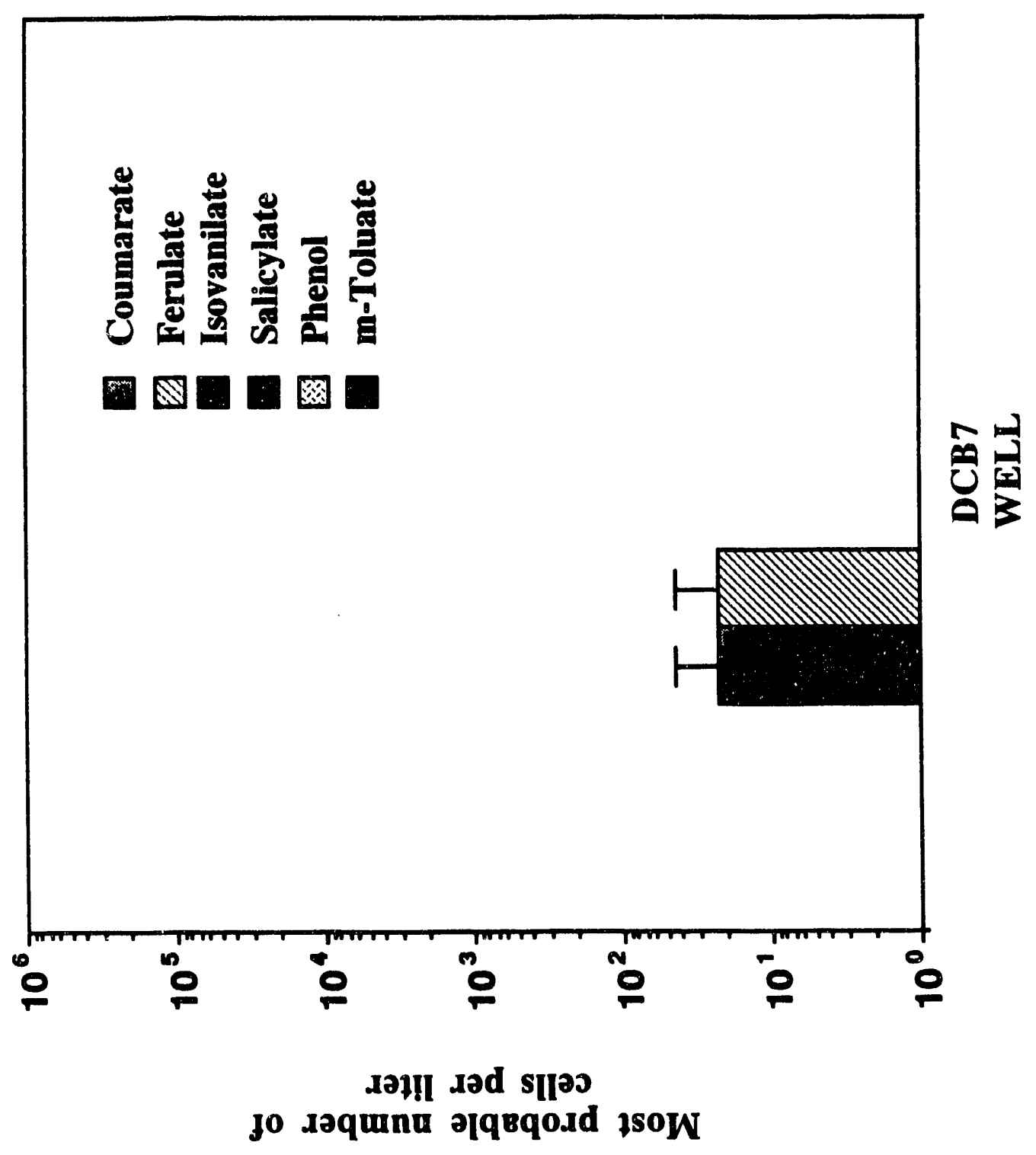




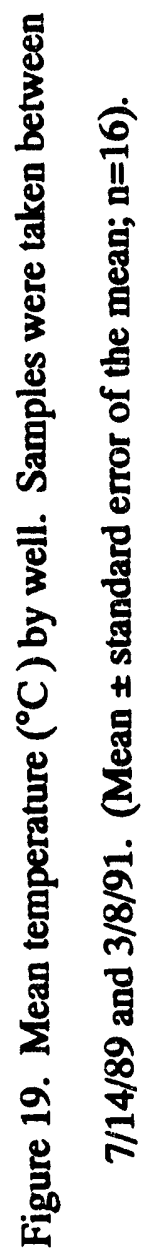


SII

\section{Temperature}

(degrees C)

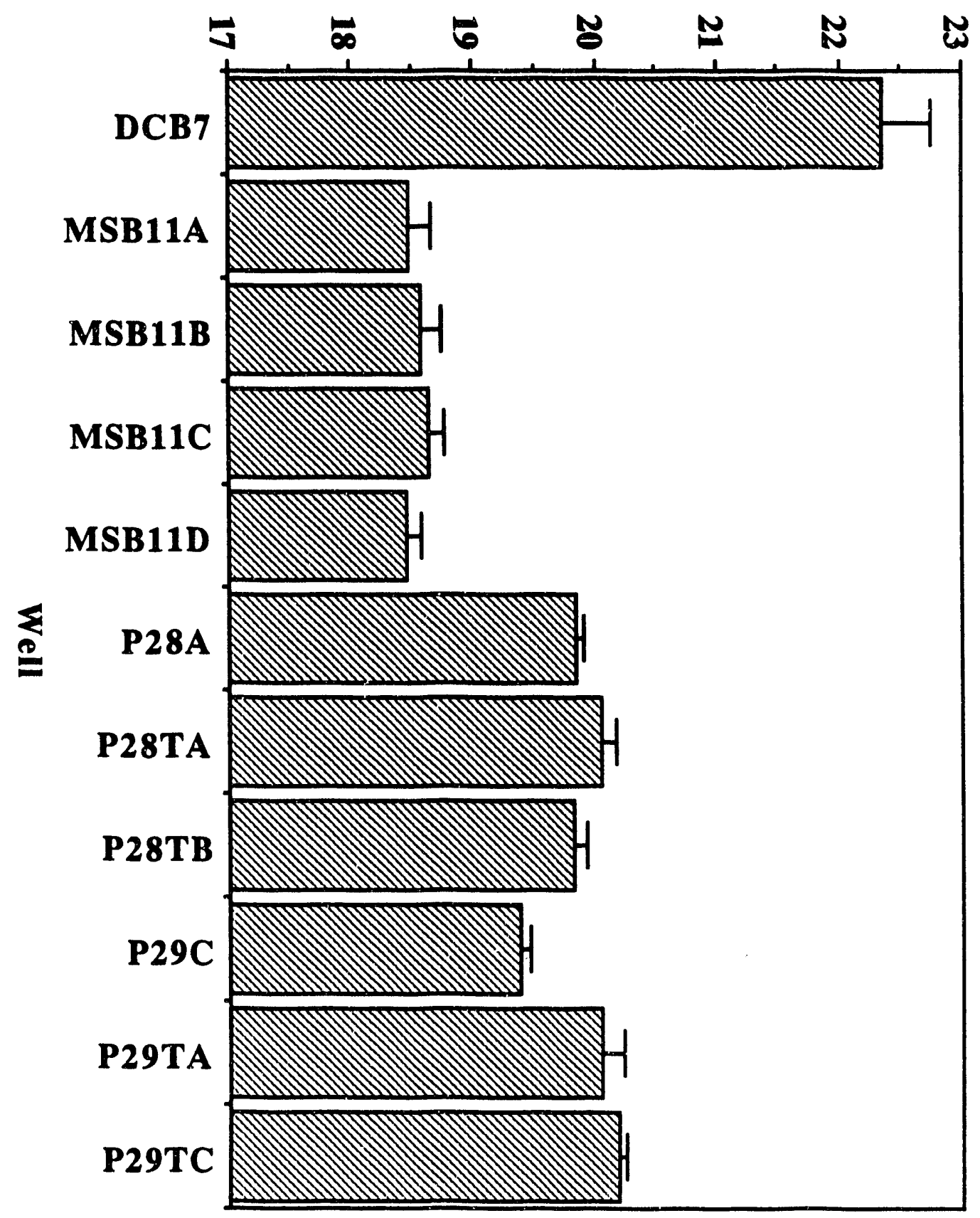




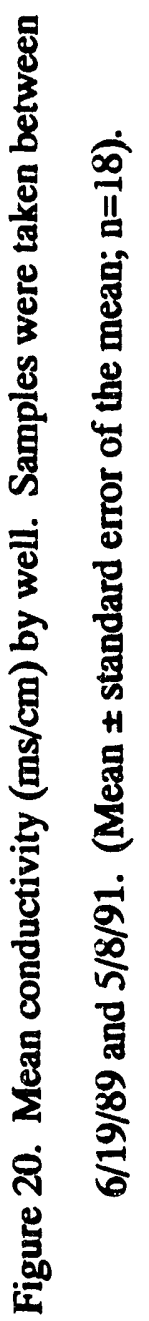




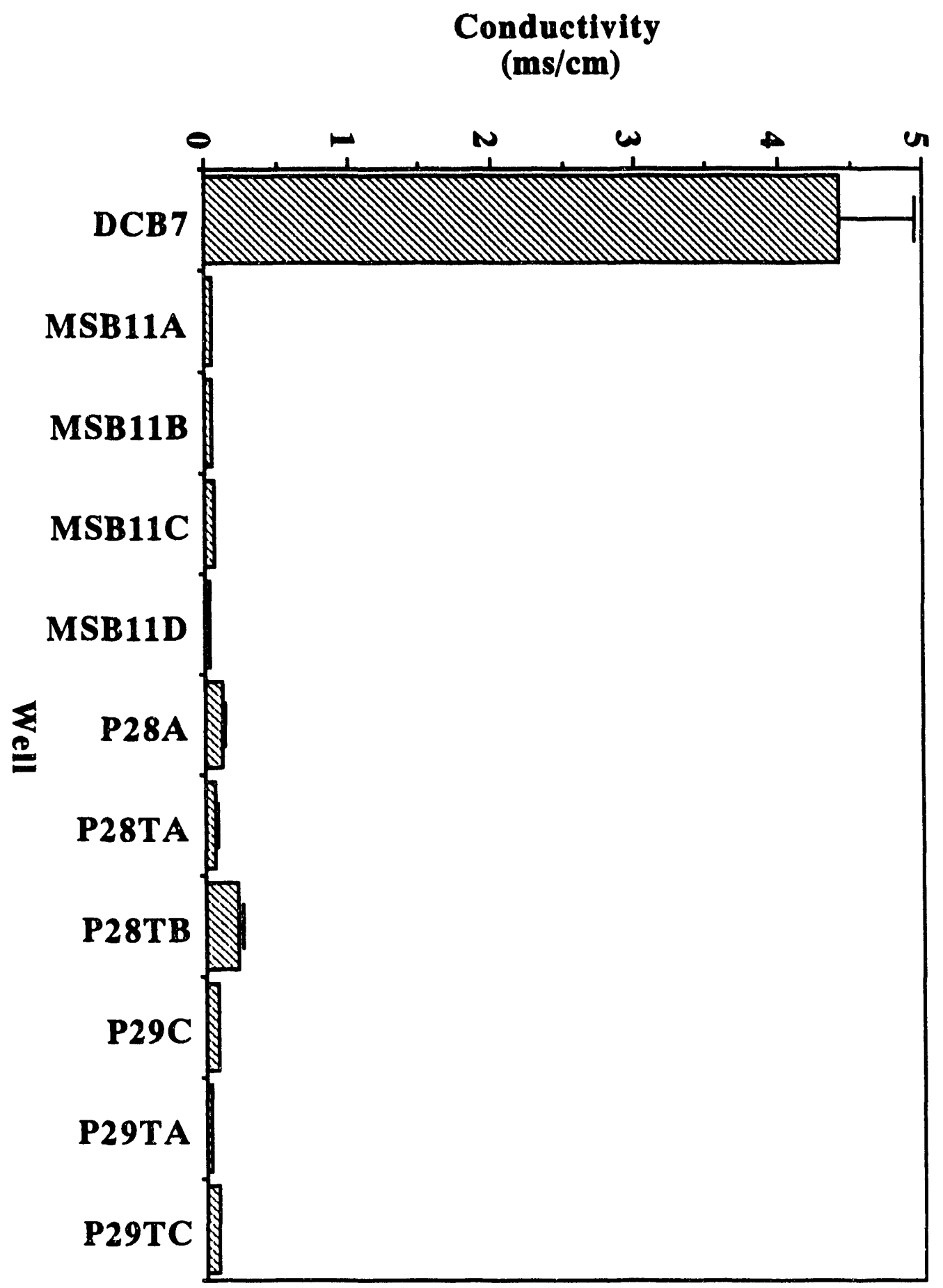




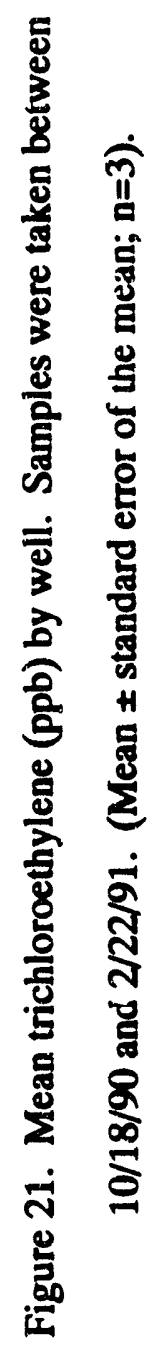




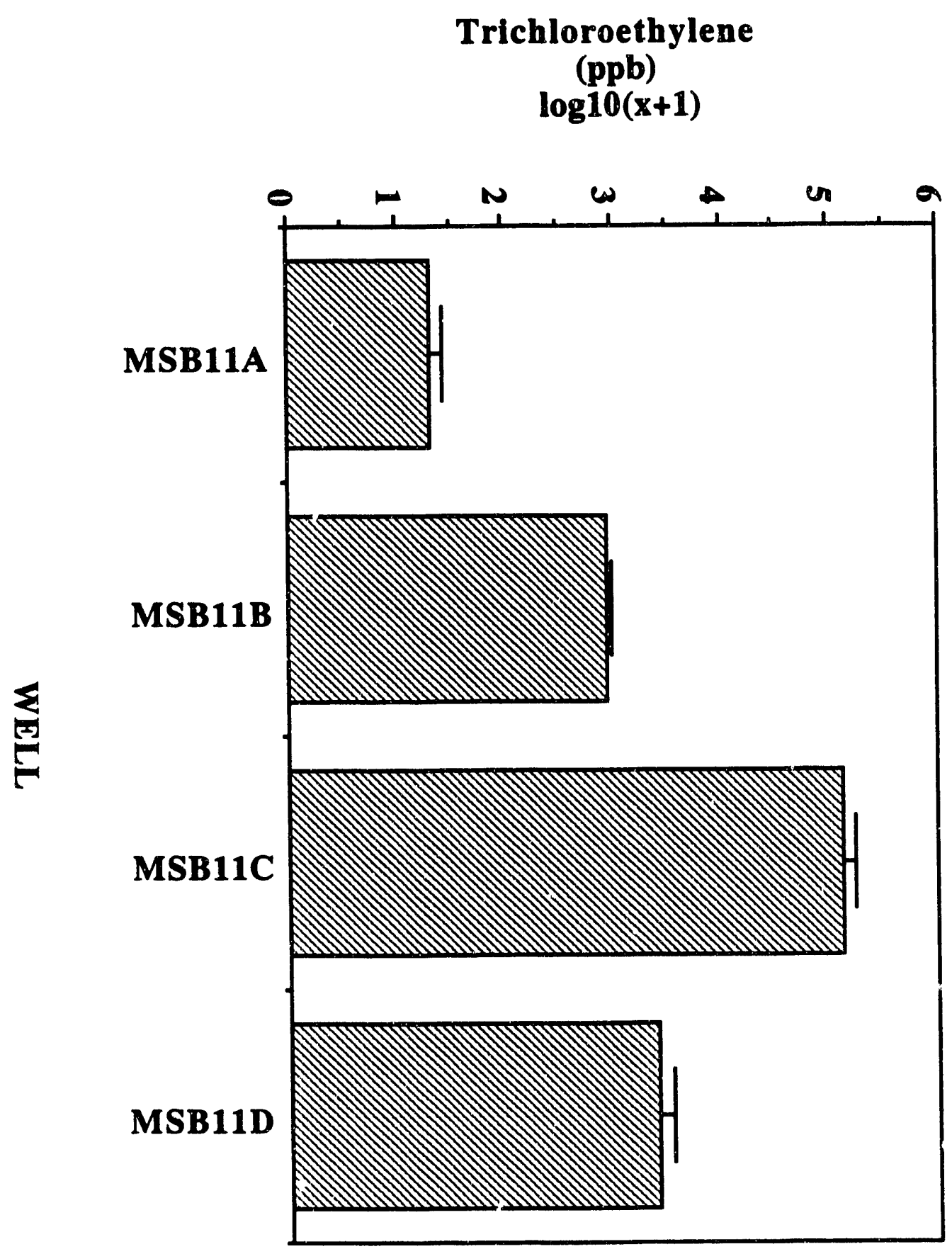




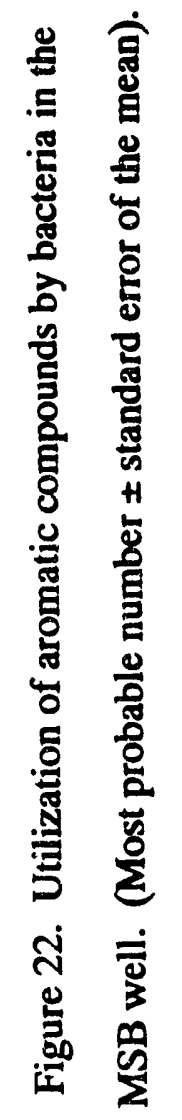




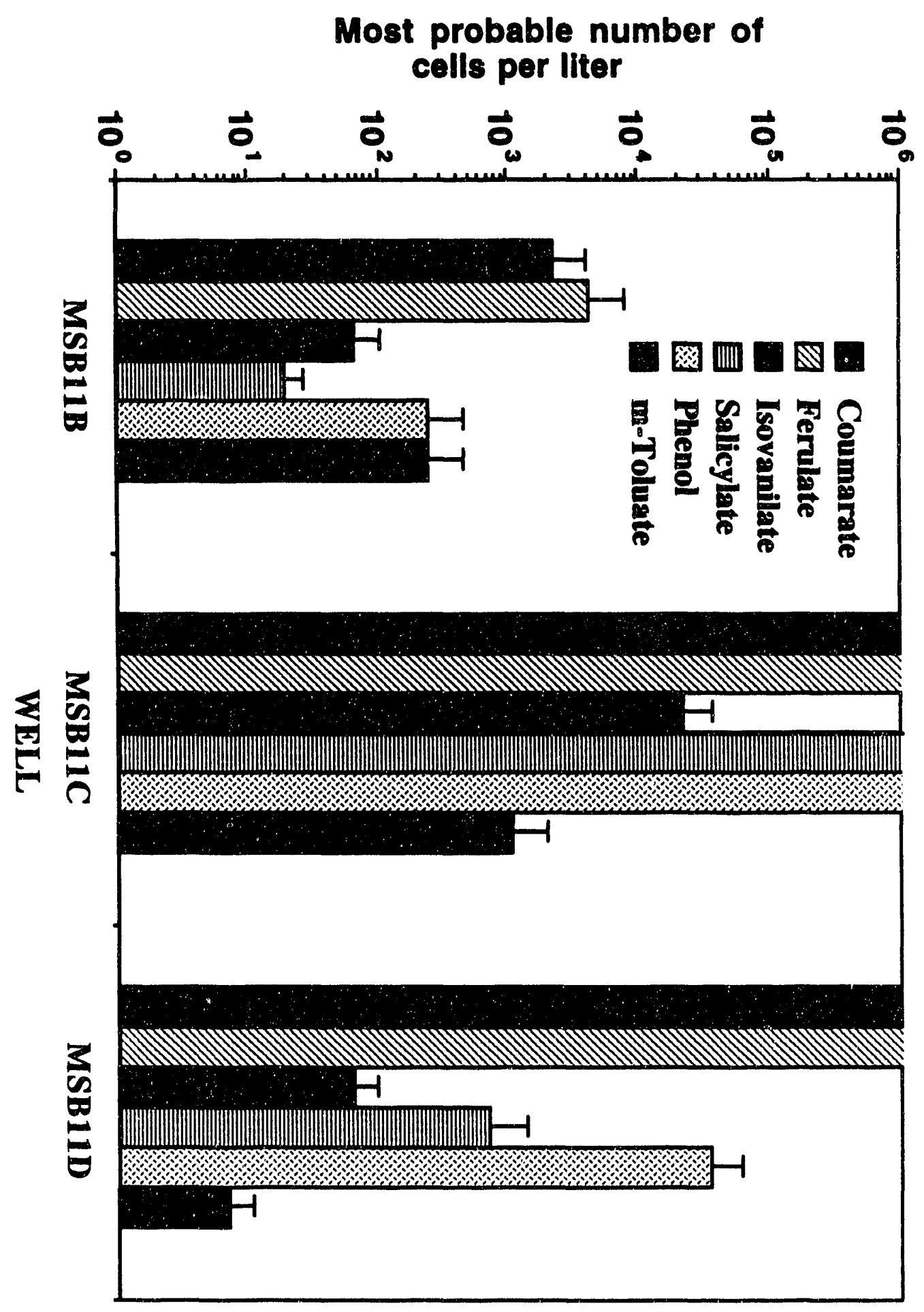




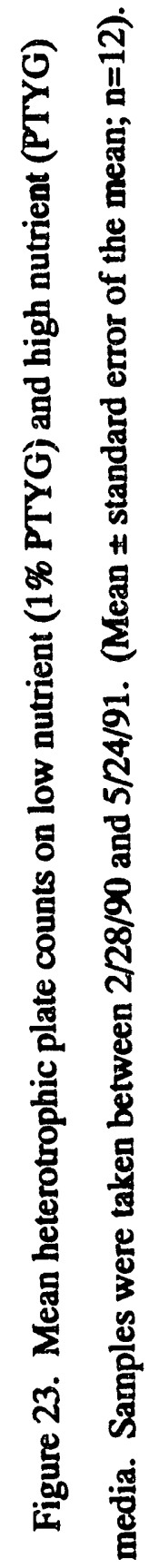




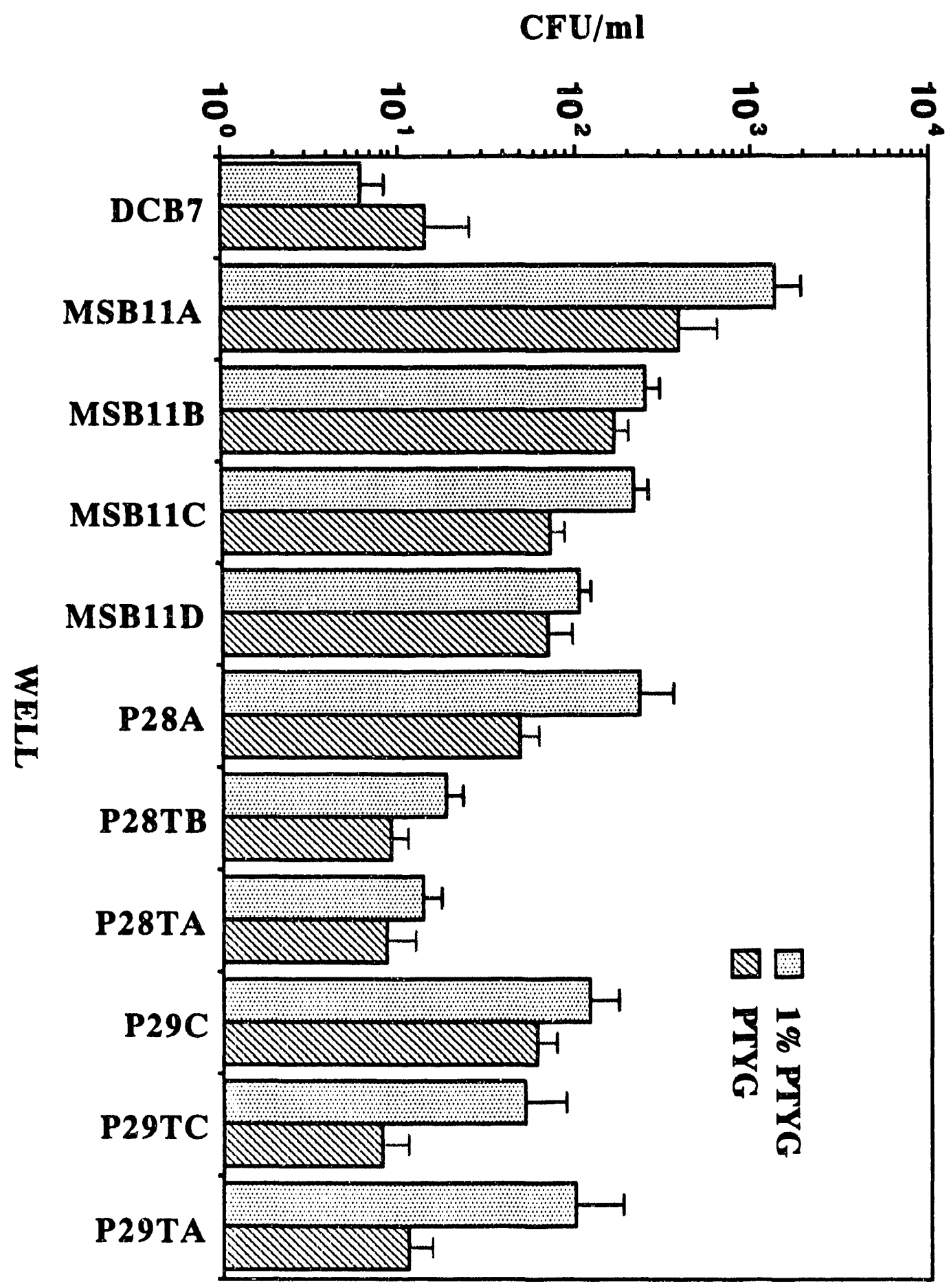




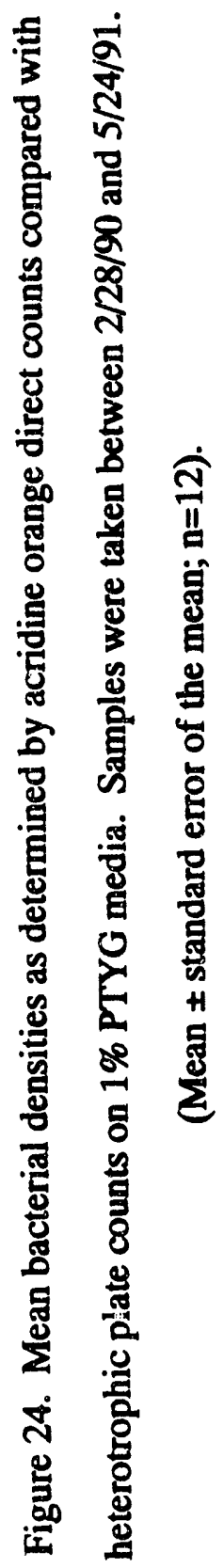




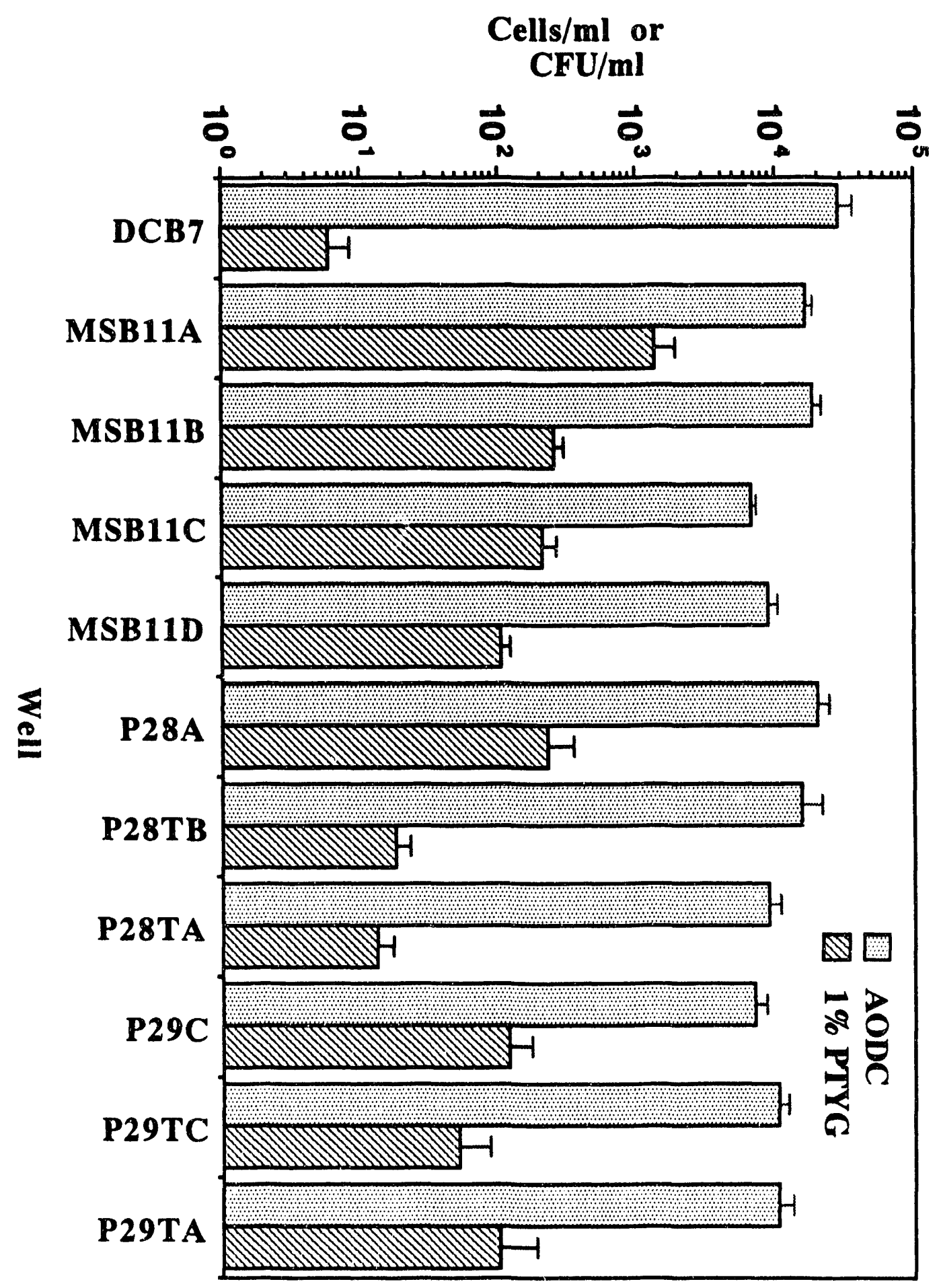


Table A-1.

Analysis of groundwater temperature by well and time. Two factor analysis of variance was performed with samples taken between 7/14/89 and 3/8/91 $(n=16)$.

\begin{tabular}{|c|c|}
\hline Summary of Fit & \\
\hline Requare & 0.895952 \\
\hline Root Moan Square Exror & 0.582716 \\
\hline Maan of Reaponse & 19.62602 \\
\hline Cbeorvations (ar sum Wgts) & 176 \\
\hline
\end{tabular}

\begin{tabular}{|c|c|c|c|c|c|}
\hline Effect $T$ & & & & & \\
\hline Source & upara & DE & sun of squares & Ratio & Prob>F \\
\hline WELL & 10 & 10 & 205.48727 & 60.5161 & 0.0000 \\
\hline TIME & 7 & 7 & 6.21639 & 2.6153 & 0.0168 \\
\hline WELL \#TIME & 70 & 70 & 45.60066 & 1.9185 & 0.0019 \\
\hline
\end{tabular}


Table A-2.

Analysis of ground water temperature by well. Samples were taken between $7 /$ $14 / 89$ and $3 / 8 / 91(n=16)$.

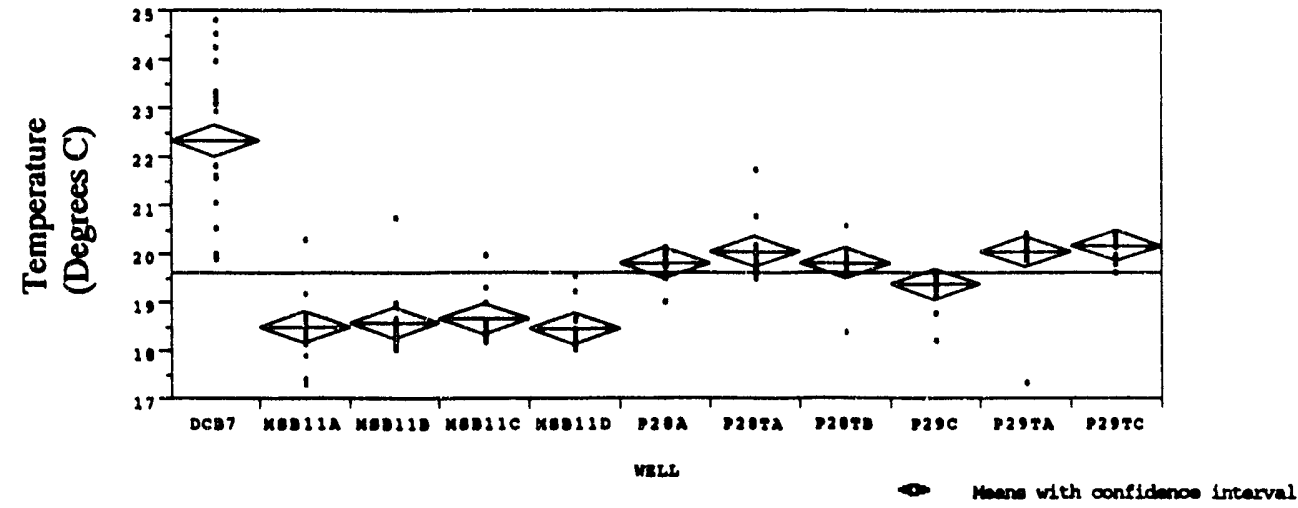

\begin{tabular}{|c|c|c|c|}
\hline 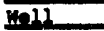 & Couint: & Men & Ftd D.x \\
\hline$\overline{D C B 7}$ & 16 & 22.34 & 1.70 \\
\hline MSBIIA & 16 & 18.49 & 0.61 \\
\hline KSB11B & 16 & 18.60 & 0.63 \\
\hline MSBIIC & 16 & 10.65 & 0.47 \\
\hline HSBIID & 16 & 18.47 & 0.42 \\
\hline P 28A & 16 & 29.84 & 0.26 \\
\hline P28TA & 16 & 20.04 & 0.55 \\
\hline P28TB & 16 & 19.83 & 0.44 \\
\hline $829 C$ & 16 & 19.38 & 0.37 \\
\hline P29TA & 16 & 20.06 & 0.73 \\
\hline P2.2Tc & 16 & 30.20 & 0.75 \\
\hline
\end{tabular}

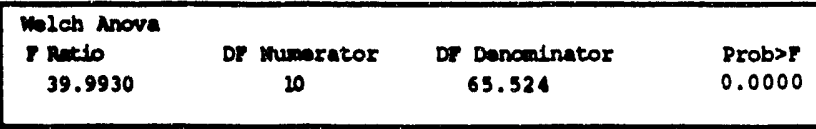

Comparison of equality of means for oxidation-reduction potential of wells as determined by Games and Howell (1976) method $(\alpha=0.05)$. Positive values represent significant differences.

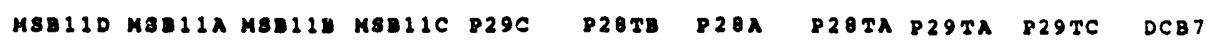

\begin{tabular}{|c|c|c|c|c|c|c|c|c|c|c|}
\hline M8D120 & - & - & - & - & + & + & + & + & + & + \\
\hline MSBIIA & - & - & - & - & - & + & + & + & + & + \\
\hline MSB $11 D$ & - & - & - & - & - & + & + & + & + & + \\
\hline$M 8 B \perp 1 C$ & - & - & - & $\infty$ & 4 & + & + & + & + & + \\
\hline $829 C$ & + & - & - & + & - & - & - & - & - & + \\
\hline P20TB & + & + & + & + & - & - & - & - & - & - \\
\hline P $28 \mathbf{A}$ & + & + & + & + & - & - & - & - & - & - \\
\hline P 28 TA & + & + & + & + & - & - & - & - & - & - \\
\hline P 29 TA & + & + & + & + & - & - & - & - & - & - \\
\hline P29TC & + & + & + & + & + & - & - & - & - & - \\
\hline DCB 7 & + & + & + & + & + & + & + & + & - & - \\
\hline
\end{tabular}




\section{Table A-3.}

Analysis of groundwater dissolved oxygen by site and time. Data was transformed by taking the square root. Two factor analysis of variance of samples taken between $7 / 14 / 89$ and $3 / 8 / 91 \quad(n=48)$.

\begin{tabular}{|c|c|}
\hline Requare & 0.458168 \\
\hline Doot Man square Brxar & 0.683357 \\
\hline Maen of Rapponses & 1.870974 \\
\hline Obeervatione (or sum Wites) & $\mathbf{1 4}$ \\
\hline
\end{tabular}

\begin{tabular}{|c|c|c|c|c|c|c|}
\hline Bouroe & Npern & DP & $\operatorname{sun}$ & of 8querea & $=\operatorname{Rat} 10$ & Prob>E \\
\hline 8I2s & 2 & 2 & & 39.274711 & 41.9451 & 0.0000 \\
\hline TIMS & 7 & 7 & & 1.927493 & 0.5897 & 0.7633 \\
\hline SITS*TIML & 14 & 14 & & 6.282307 & 0.9609 & 0.4971 \\
\hline
\end{tabular}


Table A-4.

Analysis of groundwater dissolved oxygen by site. Data was transformed by taking the square root. Single factor analysis of variance was performed with samples taken between $7 / 14 / 89$ and $3 / 8 / 91 \quad(n=48)$.

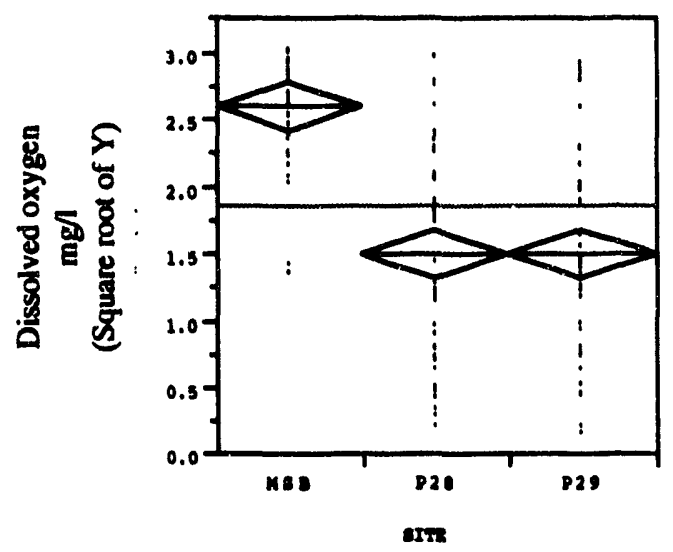

\begin{tabular}{lccc}
\hline Pelt & Count & Mean & Std DeX \\
P29 & 48 & 1.4999 & 0.7784 \\
P28 & 48 & 1.5044 & 0.7740 \\
MSB & 48 & 2.6086 & 0.4024 \\
\hline
\end{tabular}

Welch Anova

F Ratio

DE Numerator

DF Denominator

Prob $>\mathbf{F}$

62.9348

2

84.449

0.0000

Comparison of equality of means for oxidation-reduction potential of wells as determined by Games and Howell (1976) method $(\alpha=0.05)$. Positive values represent significant differences.

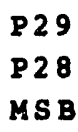

$\begin{array}{ccc}\text { 29 } & \text { P28 } & \text { MSB } \\ - & - & + \\ - & - & + \\ + & + & -\end{array}$


Table A-5.

Analysis of groundwater dissolved oxygen by well and time. Data was transformed by taking the square root. Two factor analysis of variance of samples taken between $7 / 14 / 89$ and $3 / 8 / 91 \quad(n=16)$.

\begin{tabular}{|c|c|}
\hline Summary of Itt & \\
\hline Reguare & 0.681666 \\
\hline Root man square Exror & 0.63035 \\
\hline Man of Reaponses & 1.912123 \\
\hline Obeervations (or sum Mgto) & 176 \\
\hline
\end{tabular}

\begin{tabular}{|c|c|c|c|c|c|}
\hline source & Moarn & D 7 & sun of 8quares & F nat10 & Prob>I \\
\hline WELI & 10 & 10 & 45.173109 & 11.5702 & 0.0000 \\
\hline TIAS & 7 & 7 & $3 . \$ 112153$ & 0.6875 & 0.6823 \\
\hline WELL*TIHE & 70 & 70 & 28.034651 & 1.0079 & 0.4827 \\
\hline
\end{tabular}


Table A-6.

Analysis of groundwater dissolved oxygen by well. Data was transformed by taking the square root. Single factor analysis of variance was performed with samples taken between $7 / 14 / 89$ and $3 / 8 / 91(n=16)$. Variances were homogeneous as determined by the Hartley $F$ max test.

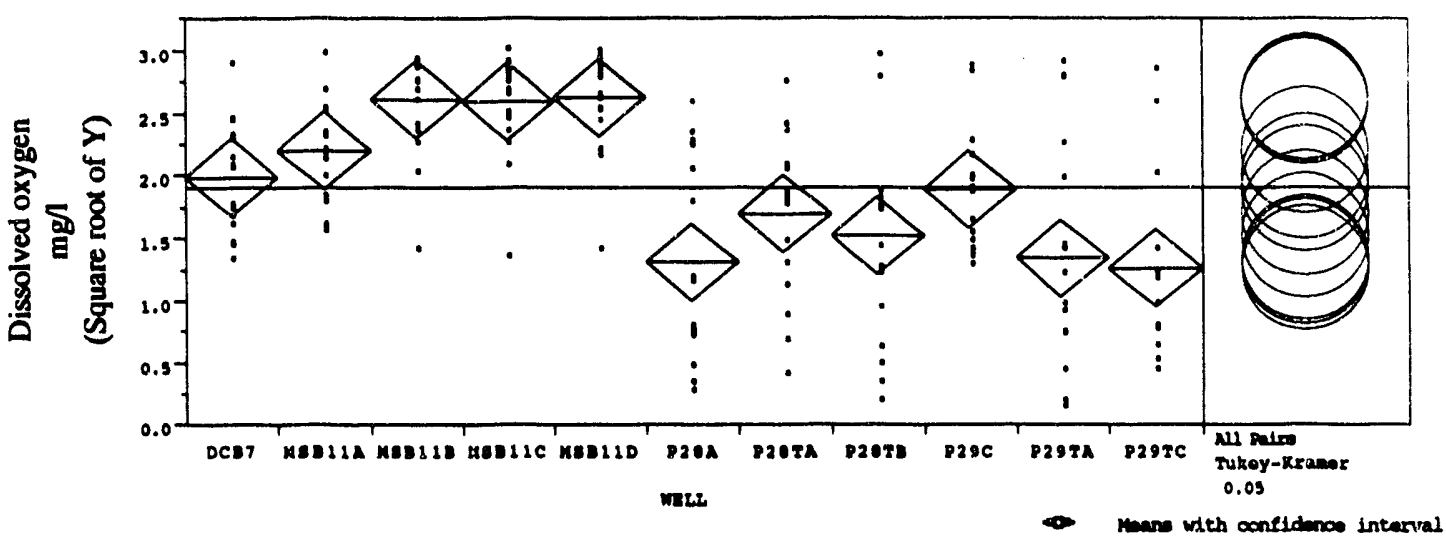

\begin{tabular}{|c|c|c|c|}
\hline 1011 & Count & Mn & sitd 101 \\
\hline DCB7 & 16 & 1.988 & 0.441 \\
\hline MSB 1 IA & 16 & 2.207 & 0.434 \\
\hline MEB 1 IB & 16 & 2.607 & 0.412 \\
\hline MSB11C & 16 & 2.593 & 0.417 \\
\hline MSB 110 & 16 & 2.624 & 0.405 \\
\hline P28A & 16 & 1.302 & 0.802 \\
\hline $\mathrm{P} 2 \mathrm{gTA}$ & 16 & 1.692 & 0.646 \\
\hline P28TB & 16 & 1.519 & 0.858 \\
\hline $829 \mathrm{C}$ & 16 & 1.896 & 0.489 \\
\hline P29TA & 16 & 1.347 & 0.958 \\
\hline P29TC & 16 & 1.256 & 0.697 \\
\hline
\end{tabular}

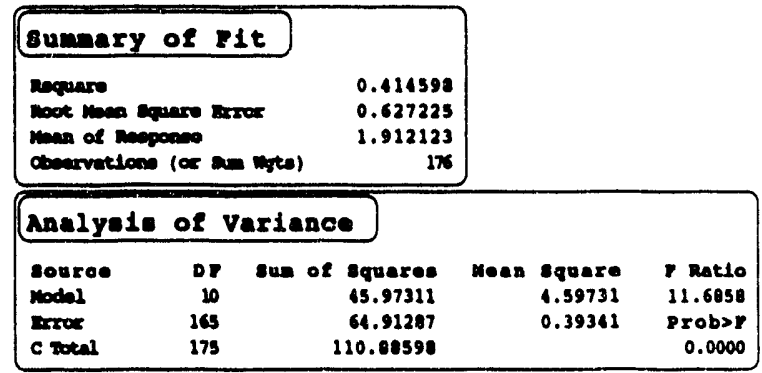

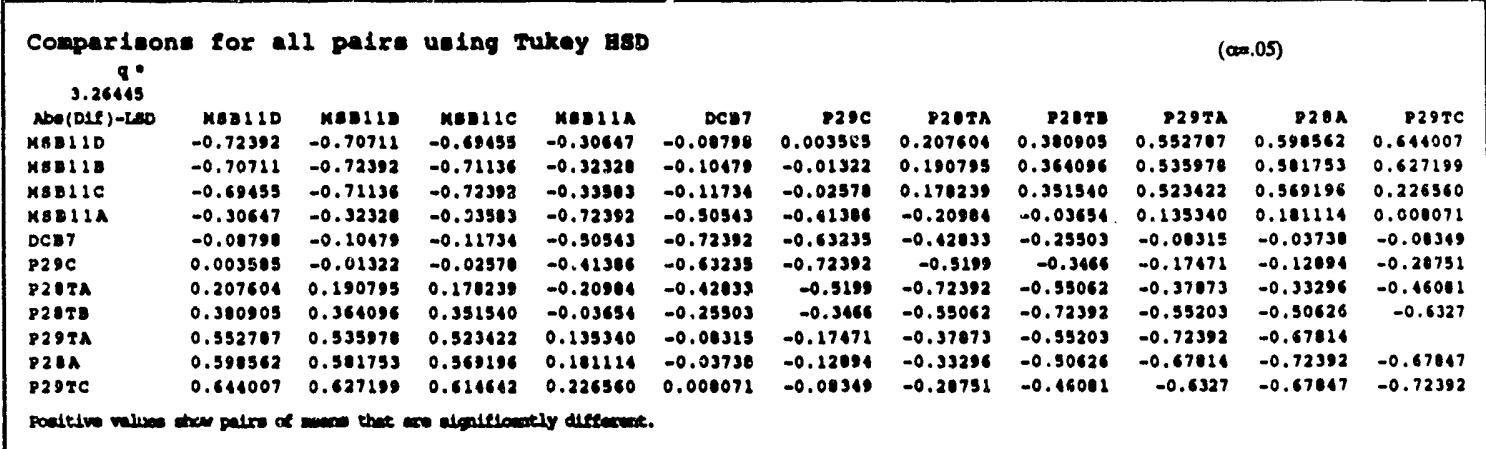


Table A-7.

Analysis of groundwater oxidation-reduction potential by site and time. Data was transforned by $(\mathrm{Y}+2)^{3}$. Two factor analysis of variance was performed with samples taken between $6 / 19 / 89$ and $5 / 08 / 91(n=48)$.

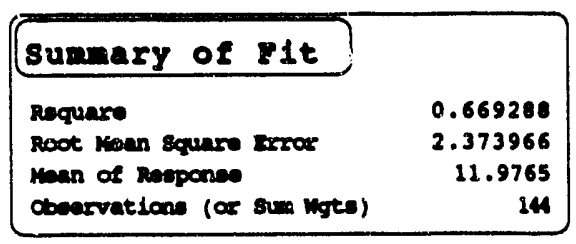

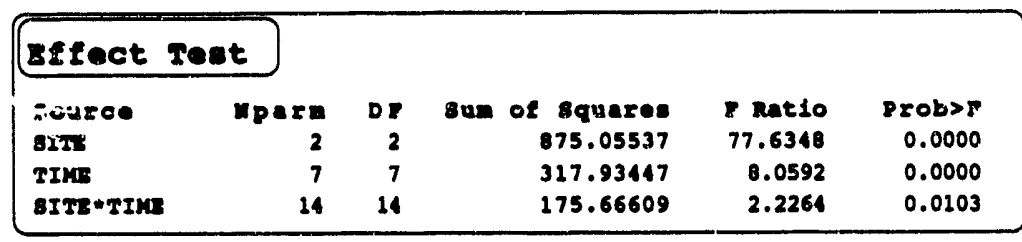


Table A-8.

Analysis of groundwater oxidation-reduction potential by site. Data was transformed by $(Y+2)^{3}$. Samples were taken between $6 / 19 / 89$ and $5 / 08 / 91$ $(n=48)$.

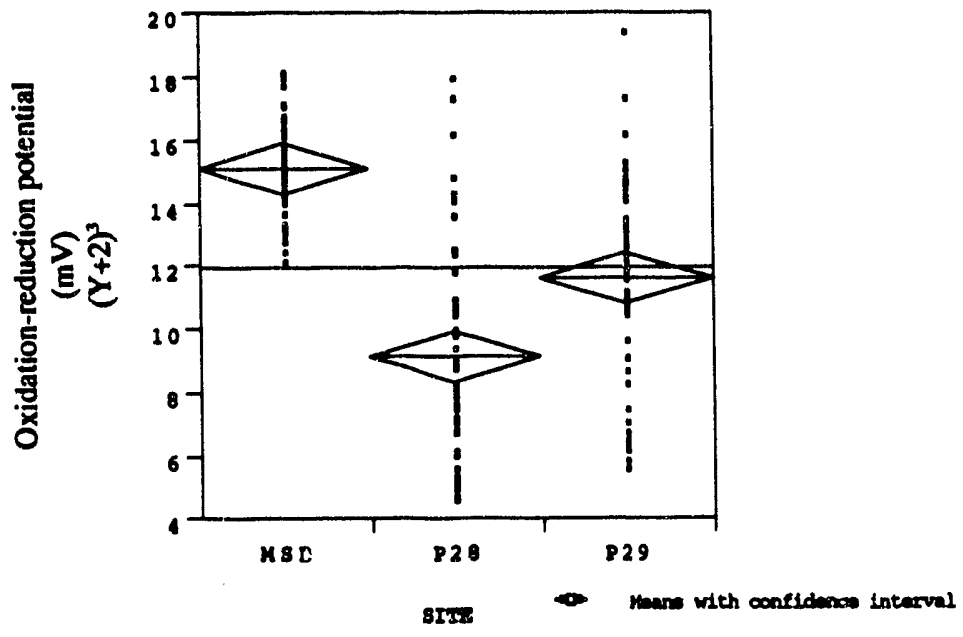

\begin{tabular}{lccc}
\hline He11 & Count & Mean & Std Dey \\
P28 & 48 & 9.134 & 3.469 \\
P29 & 48 & 11.650 & 3.233 \\
MSB & 48 & 15.146 & 1.551
\end{tabular}

$\begin{array}{cccc}\begin{array}{c}\text { Welch Anova } \\ \text { F Ratjo }\end{array} & \text { DF Numerator } & \text { DF Denominator } & \text { Prob>F } \\ 71.4642 & 2 & 81.684 & 0.0000\end{array}$

Comparison of equality of means for oxidation-reduction potential of wells as determined by Games and Howell (1976) method $(\alpha=0.05)$. Positive values represent significant differences.

$\begin{array}{lccc} & \text { P28 } & \text { P29 } & \text { MSB } \\ \text { P28 } & - & + & + \\ \text { P29 } & + & - & + \\ \text { MSB } & + & + & -\end{array}$


Table A-9.

Analysis of groundwater oxidation-reduction potential by well and time. Data was transformed by $(\mathrm{Y}+2)^{3}$. Two factor analysis of variance was performed with samples taken between 6/19/89 and 5/08/91 $(n=16)$.

\begin{tabular}{|c|c|}
\hline Summary of Fit & \\
\hline Requare & 0.797712 \\
\hline Root Man Square Error & 2.370063 \\
\hline Wean of Reeponse & 12.50361 \\
\hline Observationv (or sum Ngte) & 176 \\
\hline
\end{tabular}

\begin{tabular}{|c|c|c|c|c|c|}
\hline source & Aparn & $D F$ & 8quarea & I Rat10 & Prob $>$ F \\
\hline WELL & 20 & 10 & 1233.8632 & 21.9658 & 0.0000 \\
\hline TIME & 7 & 7 & 340.2842 & 8.6541 & 0.0000 \\
\hline WELI*TIME & 70 & 70 & 375.1519 & 0.9541 & 0.5785 \\
\hline
\end{tabular}


Table A-10.

Analysis of groundwater oxidation-reduction potential by well. Data was transformed by $(\mathrm{Y}+2)^{3}$. Samples were taken between $6 / 19 / 89$ and 5/08/91 $(n=16)$.

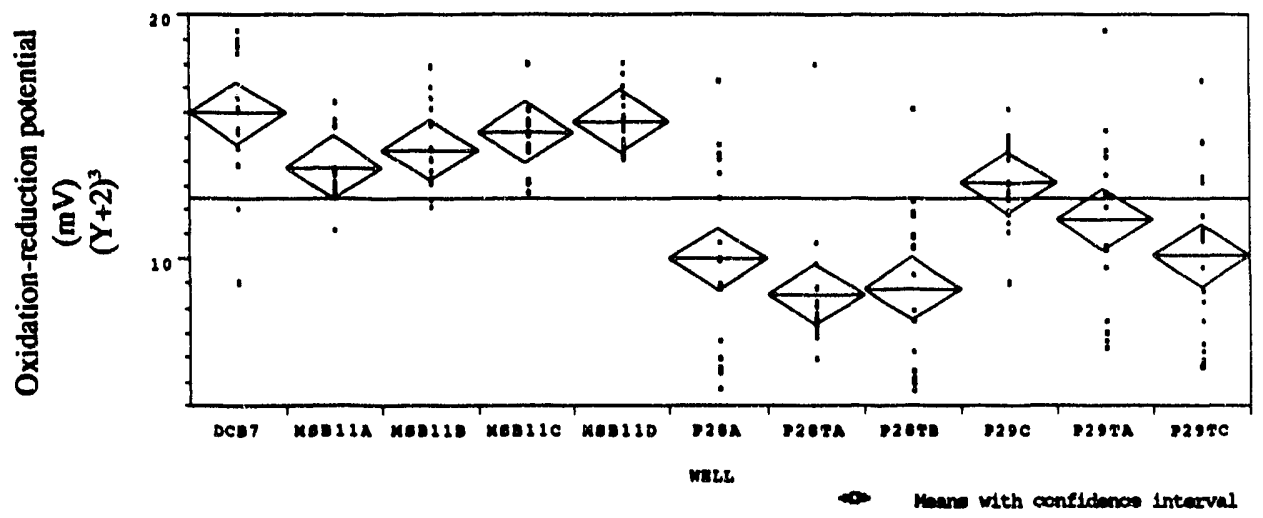

\begin{tabular}{lccc}
\hline He11 & Count & MAAn & Std DAY \\
DCB7 & 16 & 15.988 & 2.692 \\
MSB1 1A & 16 & 13.763 & 1.422 \\
MSB11B & 16 & 14.528 & 1.725 \\
MSB11C & 16 & 15.192 & 1.518 \\
MSB11D & 16 & 15.718 & 1.226 \\
P28A & 16 & 9.977 & 4.103 \\
P28TA & 16 & 8.595 & 2.794 \\
P28TB & 16 & 8.830 & 3.450 \\
P29C & 16 & 13.131 & 1.776 \\
P29TA & 16 & 11.653 & 3.594 \\
P29TC & 16 & 10.167 & 3.162
\end{tabular}

Welch ANOVA of Oxidation-Reduction Potential by well.

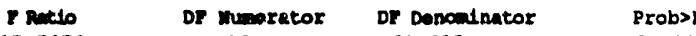

$\begin{array}{cccc}17.7070 & 10 & 65.612 & \text { Prob>F } \\ & 10 & 0.0000\end{array}$

Comparison of equality of means for oxidation-reduction potential of wells as determined by Games and Howell (1976) method $(\alpha=0.05)$. Positive values represent significant differences.

\begin{tabular}{|c|c|c|c|c|c|c|c|c|c|c|c|}
\hline & P28TA & P28TE & $828 x$ & P29TC & Р29 & P29C & MSB11A & M8B11B & M8B $1 \mathrm{C}$ & MSEIID & DCB 7 \\
\hline P28TA & - & - & - & - & - & + & + & + & + & + & + \\
\hline P20 & - & - & - & - & - & - & + & + & + & + & - \\
\hline $828 A$ & - & - & - & - & - & - & - & - & - & + & + \\
\hline P29TC & - & - & - & - & - & - & - & - & + & + & - \\
\hline P29TA & - & - & - & - & - & - & - & - & - & - & - \\
\hline P29C & + & - & - & - & - & - & - & - & - & - & - \\
\hline MSBIIA & + & + & - & - & - & - & - & - & - & - & - \\
\hline MSB 118 & + & + & - & - & - & - & - & - & - & - & - \\
\hline$M S B \perp 1 C$ & - & + & - & + & - & - & - & - & - & - & - \\
\hline MSBIID & + & + & + & $+\cdot$ & - & - & - & - & - & - & - \\
\hline DCB 7 & + & - & + & - & - & - & - & - & - & - & - \\
\hline
\end{tabular}




\section{Table A-11.}

Analysis of groundwater $\mathrm{pH}$ by site and time. Two factor analysis of variance was performed with samples taken between $6 / 19 / 89$ and 5/08/91 $(n=54)$.

\begin{tabular}{|lr|}
\hline Summary of FIt & \\
\hline Requare & 0.616086 \\
Root Moan square Error & 0.997169 \\
Moan of Reoponse & 6.094239 \\
Coservatione (or sum Hgte) & 162 \\
\hline
\end{tabular}

\begin{tabular}{|c|c|c|c|c|c|c|}
\hline source & Npern & D $\mathbf{z}$ & sus & of squeres & I Ratio & Probs: \\
\hline SI25 & 2 & 2 & & 171.49258 & 86.2339 & 0.0000 \\
\hline TIME & 8 & 8 & & 12.07777 & 1.5183 & 0.1564 \\
\hline SITS*TIH & 16 & 16 & & 32.57623 & 2.0476 & 0.0142 \\
\hline
\end{tabular}


Table A-12.

Analysis of groundwater pH by site. Samples were taken between 6/19/89 and $5 / 08 / 91(n=54)$.

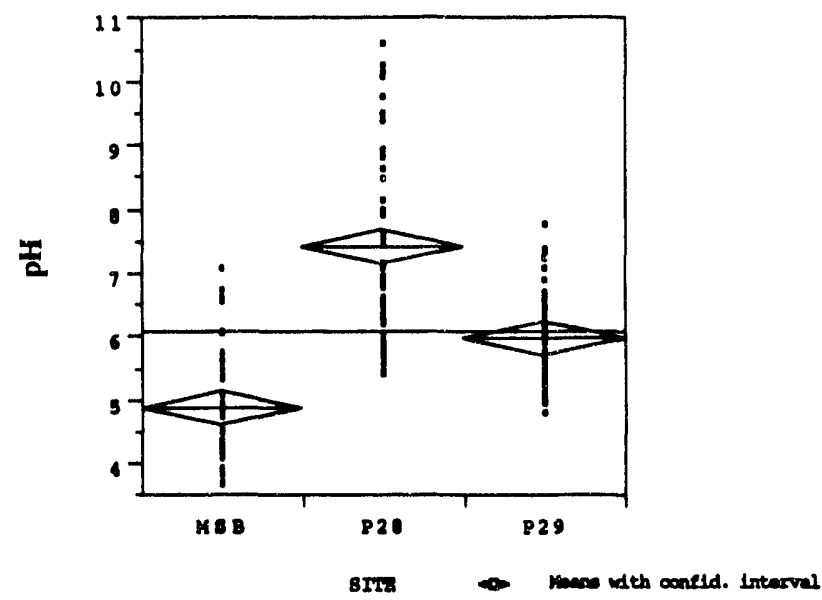

\begin{tabular}{lccc}
\hline Hall & Count & Man & Std Dex \\
M S B & 54 & 4.90 & 0.84 \\
P28 & 54 & 7.41 & 1.46 \\
P29 & 54 & 5.98 & 0.73 \\
\hline
\end{tabular}

Welch Anove

Rat1o

DF Numerator

DF Denominator

Prob>F

64.9599

2 100.61

0.0000

Comparison of equality of means for oxidation-reduction potential of wells as determined by Games and Howell (1976) method $(\alpha=0.05)$. Positive values represent significant differences.

$\begin{array}{cccc} & \text { MSB } & \text { P29 } & \text { P28 } \\ \text { MSB } & - & + & + \\ \text { P29 } & + & - & + \\ \text { P28 } & + & + & -\end{array}$


Table A-13.

Analysis of groundwater $\mathrm{pH}$ by well and time. Two factor analysis of variance was performed with samples taken between $6 / 19 / 89$ and 5/08/91 $(n=16)$.

\begin{tabular}{|lr|}
\hline Summary of Fit \\
\hline Requare & \\
Root mean square Error & 0.893813 \\
Moan of Reaprnes & 0.780662 \\
Obearvations (or sum wgte) & 5.770556 \\
\hline
\end{tabular}

\begin{tabular}{|lrrrrrr|}
\hline Effect Test & & & & & \\
Source & MPArI & DF & 8un of 8quares & F Rat10 & Prob>P \\
HELL & 10 & 10 & 107.39149 & 66.8476 & 0.0000 \\
TIME & 8 & 8 & 11.10209 & 2.2771 & 0.0279 \\
WELL*TIME & 80 & 80 & 89.51781 & 1.8361 & 0.0021 \\
\hline
\end{tabular}


Table A-14.

Analysis of groundwater $\mathrm{pH}$ by well. Samples were taken between 6/19/89 and $5 / 08 / 91(n=18)$

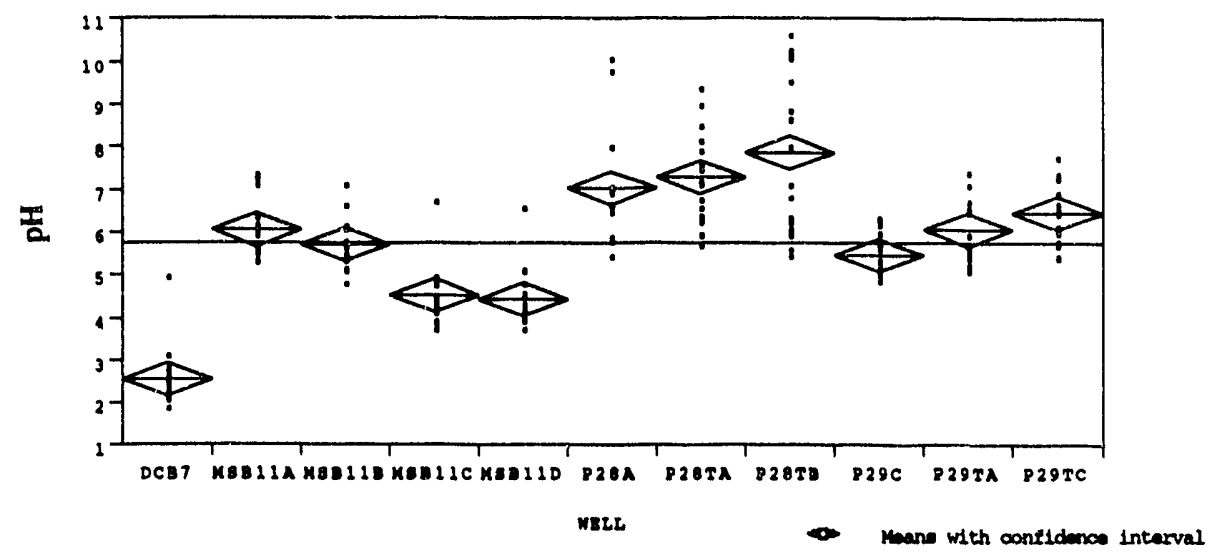

\begin{tabular}{lccc}
\hline Hel1 & Count & MeNn & Std P.Y \\
DCB7 & 18 & 2.57 & 0.68 \\
MSB11A & 18 & 6.06 & 0.64 \\
MSB11B & 18 & 5.70 & 0.57 \\
MSB11C & 18 & 4.54 & 0.66 \\
MSB11D & 18 & 4.44 & 0.63 \\
P28A & 18 & 7.06 & 1.25 \\
P28TA & 18 & 7.27 & 1.05 \\
P28TB & 18 & 7.90 & 1.89 \\
P29C & 18 & 5.48 & 0.48 \\
P29TA & 18 & 6.03 & 0.71 \\
P29TC & 18 & 6.43 & 0.68
\end{tabular}

Welch ANDVA of pH by well.

F sutso

34.2627

DF Muarato

10

DF Denominator

Prob>F

74.593

0.0000

Comparison of equality of means for $\mathrm{pH}$ of wells as determined by Games and Howell (1976) method $(\alpha=0.05)$. Positive values represent significant differences.

\begin{tabular}{|c|c|c|c|c|c|c|c|c|c|c|c|}
\hline & DCB 7 & $M 88110$ & M8B11C & P29C & M8B11B & P29TA & M8B $11 A$ & Р29TC & P2OA & P28TA & $\mathrm{P} 28 \mathrm{~TB}$ \\
\hline $\mathrm{DCB} 7$ & - & + & + & + & + & + & + & + & + & + & + \\
\hline M8B110 & + & - & - & + & + & + & + & + & + & + & + \\
\hline MSB11C & + & - & - & + & + & + & + & + & + & + & + \\
\hline P29C & + & + & + & - & - & - & - & + & + & + & - \\
\hline MSB11B & + & + & + & - & - & - & - & - & - & + & - \\
\hline P $29 \mathrm{TA}$ & + & + & + & - & - & - & - & - & - & - & - \\
\hline M8B11A & + & + & + & - & - & - & - & - & - & - & - \\
\hline P29TC & + & + & + & + & - & - & - & - & - & - & - \\
\hline P 28 A & + & + & + & + & - & - & - & - & - & - & - \\
\hline P $28 \mathrm{TA}$ & + & + & + & + & + & - & - & - & - & - & - \\
\hline P28TB & + & + & + & - & - & - & - & - & - & - & - \\
\hline
\end{tabular}


Table A-15.

Analysis of groundwater conductivity by well and time. Data was transformed using the arc sine square root. Two factor analysis of variance was performed with samples taken between $6 / 19 / 89$ and $5 / 08 / 91(n=18)$.

\begin{tabular}{|lr|}
\hline Summary of Fit \\
\hline Requare & 0.80437 \\
Root Mean square Error & 0.071045 \\
Moan of Reaponse & 0.265323 \\
Cbeervations (or sum wgta) & 180 \\
\hline
\end{tabular}

\begin{tabular}{|c|c|c|c|c|c|}
\hline source & Mparm & DP & sum of 8queres & F Rat1o & P cob $>$ F \\
\hline NELI & 9 & 9 & 1.0705006 & 23.5656 & 0.0000 \\
\hline TIRE & 8 & 8 & 0.1384568 & 3.4289 & 0.0017 \\
\hline WELL*TIME & 72 & 72 & 0.6588421 & 1.8129 & 0.0038 \\
\hline
\end{tabular}


Table A-16.

Analysis of groundwater conductivity by well. Samples were transformed using arc sine square root. Samples were taken between 6/19/89 and 5/08/91 $(n=18)$.

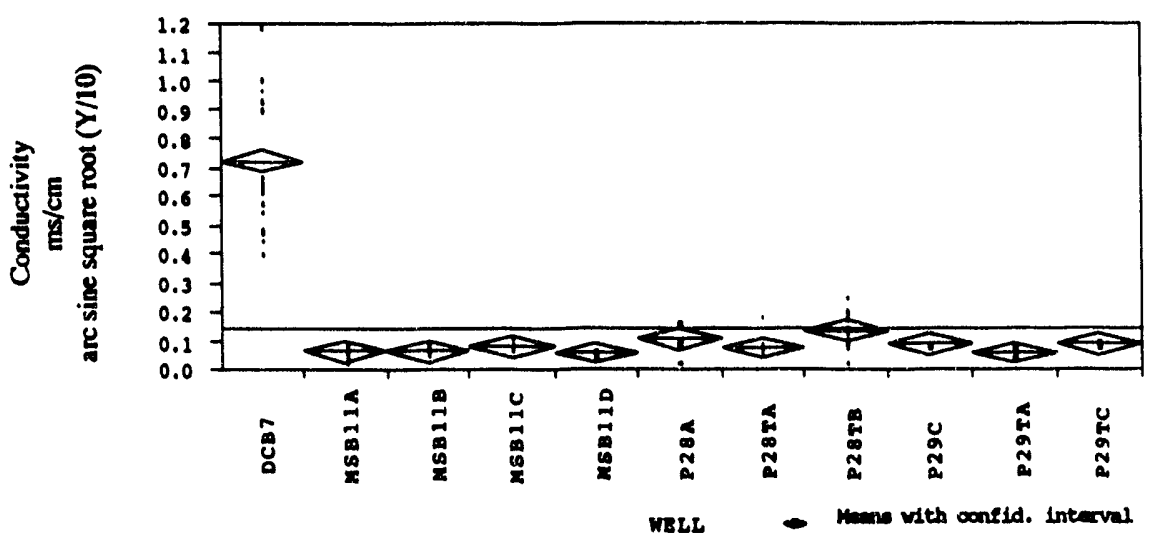

\begin{tabular}{|c|c|c|c|}
\hline mil & Count- & Menn & sted Dev \\
\hline MSBIID & 18 & 0.0563 & 0.0061 \\
\hline P292A & 18 & 0.0606 & 0.0124 \\
\hline MSB11A & 18 & 0.0647 & 0.0163 \\
\hline MSB118 & 18 & 0.0667 & 0.0115 \\
\hline P28TA & 18 & 0.0769 & 0.0274 \\
\hline K8B11C & 18 & 0.0824 & 0.0098 \\
\hline P29TC & 18 & 0.0877 & 0.0080 \\
\hline P29C & 18 & 0.0893 & 0.0061 \\
\hline P28A & 10 & 0.1036 & 0.0364 \\
\hline P2 8T: & 10 & 0.1357 & 0.0370 \\
\hline DCR7 & 10 & 0.7260 & 0.22775 \\
\hline
\end{tabular}

Welch ANOVA of conductivity by well.

F Ratio DF Numerator DF Denominator Probs

$\begin{array}{llll}51.3898 & 10 & 73.958 & 0.0000\end{array}$

Comparison of equality of means for $\mathrm{pH}$ of wells as determined by Games and Howell (1976) method ( $\alpha=0.05$ ). Positive values represent significant differences.

\begin{tabular}{|c|c|c|c|c|c|c|c|c|c|c|c|}
\hline & MBBIID & P29TA & MSE11A & M8B11B & P28TA & MBB $1 \mathrm{C}$ & P29TC & $829 \mathrm{C}$ & P28A & P28TB & DCB 7 \\
\hline MSB110 & - & - & - & - & - & + & + & + & + & + & + \\
\hline $829 \mathrm{TA}$ & - & - & - & - & - & + & + & + & - & + & + \\
\hline MSBI $1 \mathrm{~A}$ & - & - & - & - & - & - & + & + & - & + & + \\
\hline MSB $11 B$ & - & - & - & - & - & - & + & + & - & - & + \\
\hline P28TA & - & - & - & - & - & - & - & - & - & - & + \\
\hline MSBI $1 \mathrm{C}$ & + & + & - & - & - & - & - & - & - & - & + \\
\hline P29TC & + & + & + & + & - & - & - & - & - & - & + \\
\hline $829 \mathrm{C}$ & + & + & + & + & - & - & - & - & - & - & + \\
\hline $828 A$ & + & - & - & - & - & - & - & - & - & - & + \\
\hline P28TB & + & + & + & - & - & - & - & - & - & - & + \\
\hline DCB 7 & + & + & + & + & + & + & + & + & + & + & + \\
\hline
\end{tabular}


Table A-17.

Analysis of ground water acridine orange direct counts by site and time. Data was transformed using $\log _{10}(Y+1)$. Two factor analysis of variance was performed on samples taken between 6/19/89 and 5/08/91 $(n=60)$.

\begin{tabular}{|lr|}
\hline Summary of F1t \\
\hline Requare & 0.166545 \\
Root Hean Square Error & 0.719534 \\
Mean of Reopense & 0.945716 \\
Obeorvat lons (or sum Wgta) & 180 \\
\hline
\end{tabular}

\begin{tabular}{|c|c|c|c|c|}
\hline \multicolumn{5}{|c|}{ Effect Tost } \\
\hline source & Mpaxa & gun of & squazas & Prob>P \\
\hline site & 2 & 2 & 5.026115 & 0.0091 \\
\hline Tine & 9 & 9 & & 0.0000 \\
\hline sito"rimo & 18 & 18 & & 0.0005 \\
\hline
\end{tabular}


Table A-18.

Analysis of ground water acridine orange direct counts by site. Data was transformed using $\log _{10}(Y+1)$. Samples were taken between $6 / 19 / 89$ and $5 /$ $08 / 91(n=60)$.

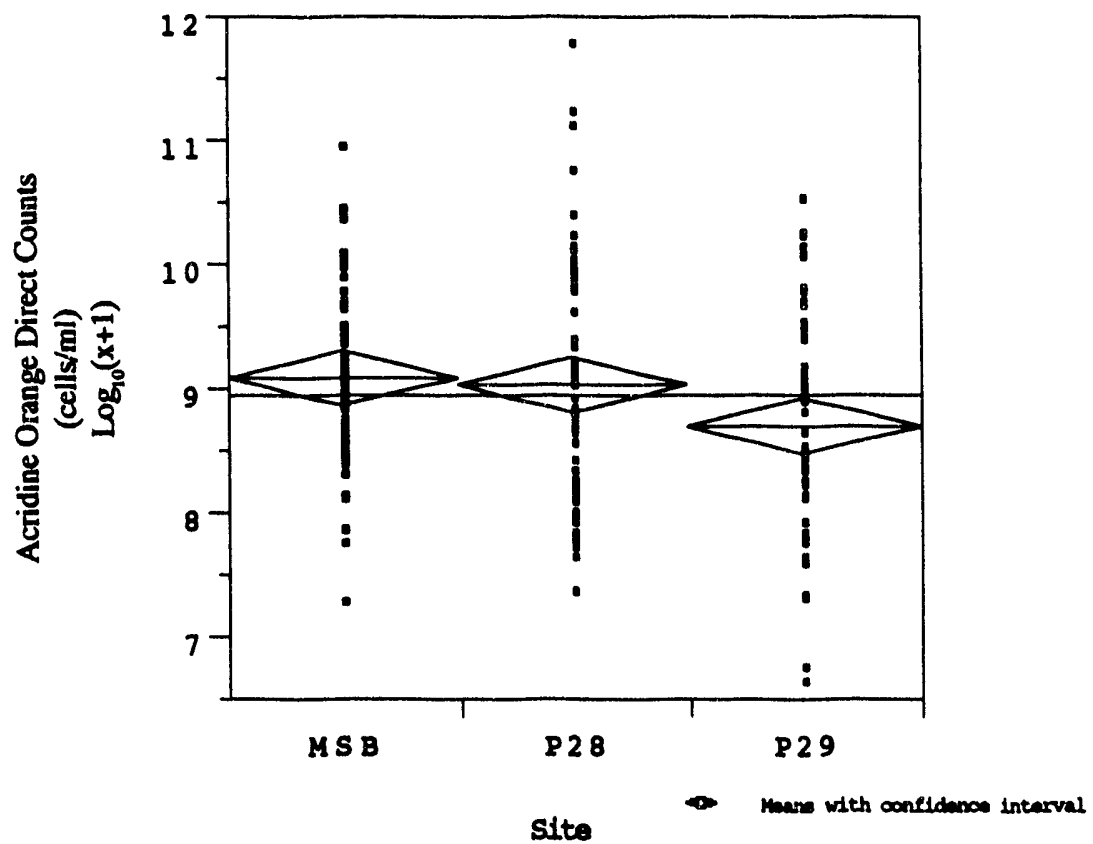

\begin{tabular}{lccc}
\hline Hell & Number & Mean & Std Dey \\
MS B & 60 & 9.0899 & 0.6977 \\
P2 8 & 60 & 9.0357 & 0.9909 \\
P29 & 60 & 8.7115 & 0.9558
\end{tabular}

Welch Anova
F Ratio
F Numerator
DF Denominator
Prob>F
3.1881
2
114.7
0.0449

Comparison of equality of means for $\mathrm{pH}$ of wells as determined by Games and Howell (1976) method $(\alpha=0.05)$. Positive values represent significant differences.

$\begin{array}{cccc} & \text { P29 } & \text { P28 } & \text { MSB } \\ \text { P29 } & - & - & - \\ \text { P28 } & - & - & - \\ \text { MSB } & - & - & -\end{array}$




\section{Table A-19.}

Analysis of ground water acridine orange direct counts by well and time. Data was transformed using $\log _{10}(Y+1)$. Two factor analysis of variance was performed on samples taken between 6/19/89 and 5/08/91 $(n=20)$.

\begin{tabular}{|c|c|}
\hline Summary of Fit & \\
\hline Requare & 0.723187 \\
\hline Root moan square Error & 0.687493 \\
\hline mean of responses & 9.097208 \\
\hline Obeervation (or sua wgte) & 220 \\
\hline
\end{tabular}

\begin{tabular}{|c|c|c|c|c|c|}
\hline Source & upara & DF & sun of squares & F Rat1o & Prob $>F$ \\
\hline WELI & 10 & 10 & 46.527172 & 9.8440 & 0.0000 \\
\hline$T 1 \times 0$ & 9 & 9 & 35.806424 & 8.4175 & 0.0000 \\
\hline WELL"TIMO & 90 & 90 & 53.495601 & 1.2576 & 0.1256 \\
\hline
\end{tabular}




\section{Table A-20.}

Analysis of ground water acridine orange direct counts by well. Data was transformed using $\log _{10}(Y+1)$. Samples were taken between 6/19/89 and 5/ $08 / 91(n=20)$.

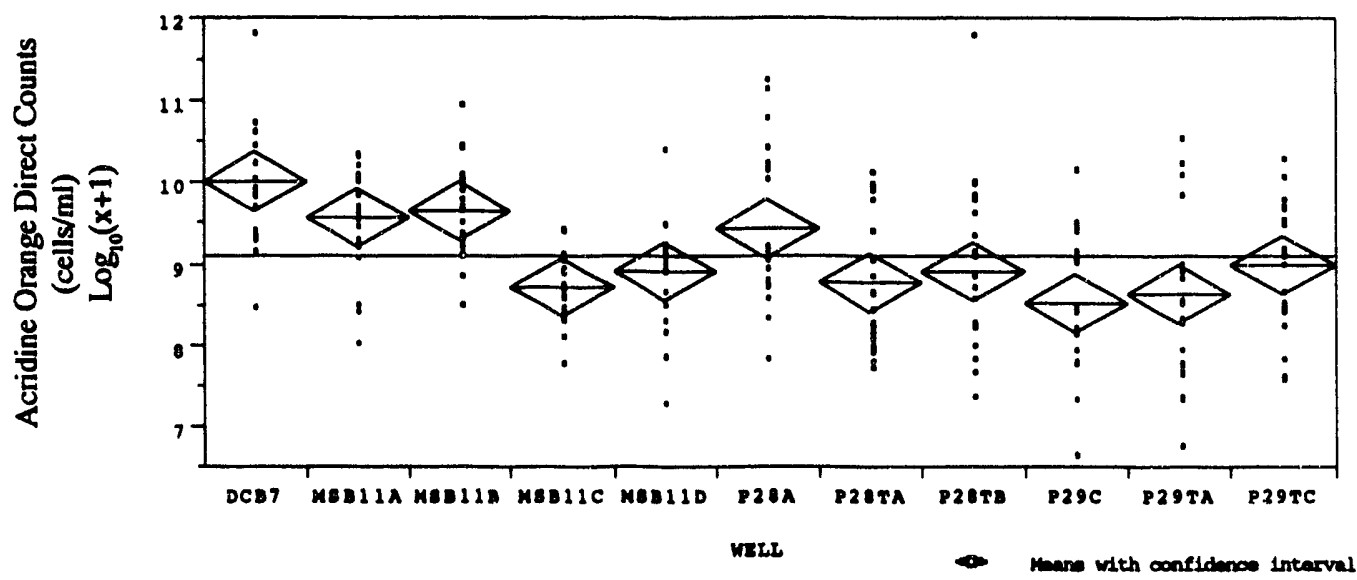

\begin{tabular}{lccc}
\hline We11 & Count & Marn & StdD.Y \\
P29C & 20 & 8.5116 & 0.3877 \\
P29TA & 20 & 8.6201 & 1.1377 \\
MSB11C & 20 & 8.7229 & 0.4217 \\
P28TA & 20 & 8.7729 & 0.8226 \\
MSB11D & 20 & 8.8983 & 0.6410 \\
P28TB & 20 & 8.9173 & 1.0857 \\
P29TC & 20 & 9.0027 & 0.7838 \\
P28A & 20 & 9.4171 & 0.9762 \\
MSB11A & 20 & 9.5625 & 0.6508 \\
MSB11B & 20 & 9.6487 & 0.6431 \\
DCB7 & 20 & 9.9954 & 0.7108
\end{tabular}

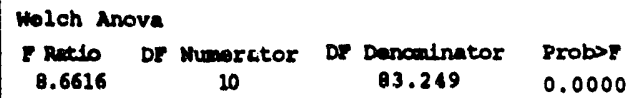

Comparison of equality of means for $\mathrm{pH}$ of wells as determined by Games and Howell (1976) method $(\alpha=0.05)$. Positive values represent significant differences.

\begin{tabular}{|c|c|c|c|c|c|c|c|c|c|c|c|}
\hline & $829 \mathrm{C}$ & $829 \mathrm{IA}$ & M8B11C & P28T & MSB11D & P28T8 & $829 \mathrm{TC}$ & P $28 \mathrm{~A}$ & MSB I IA & MSBIIB & DCE 7 \\
\hline $829 \mathrm{C}$ & - & - & - & - & - & - & - & - & - & - & - \\
\hline P29TA & - & - & - & - & - & - & - & - & $=$ & - & - \\
\hline MSBd1C & - & - & - & - & - & - & - & - & + & + & + \\
\hline Р28TA & - & - & - & - & - & - & - & - & - & - & + \\
\hline MSB 110 & - & - & - & - & - & - & - & - & - & - & + \\
\hline $828 \mathrm{~TB}$ & - & - & - & - & - & - & - & - & - & - & - \\
\hline $829 \mathrm{TC}$ & - & - & - & - & - & - & - & - & - & - & - \\
\hline$P 28 A$ & - & - & - & - & - & - & - & - & - & - & - \\
\hline MSBIIA & - & - & + & - & - & - & - & - & - & - & - \\
\hline MSBIIB & - & - & + & - & - & - & - & - & - & - & - \\
\hline DCB 7 & - & - & + & + & + & - & - & - & - & - & - \\
\hline
\end{tabular}




\section{Table A-21.}

Analysis of ground water heterotrophic viable counts on 1\% PTYG (low nutrient) agar by site and time. Data was transformed using $\log _{10}(\mathrm{Y}+1)$. Two factor analysis of variance was performed on samples taken between $6 / 19 / 89$ and $5 / 08 / 91(n=60)$.

\begin{tabular}{|c|c|}
\hline summary of pit & \\
\hline Requare & 0.497514 \\
\hline Root Man Square Irror & 0.558074 \\
\hline Man of Reoponse & 2.49231 \\
\hline obeervatione (or sun ngte) & 180 \\
\hline
\end{tabular}

\begin{tabular}{|c|c|c|c|c|c|c|}
\hline 8ouroe & npaxa & DE & sum & of squaren & - Ratio & Prob>P \\
\hline 8I2t: & 2 & 2 & & 25.502942 & $\begin{array}{r}40.9427 \\
5.7053\end{array}$ & $\begin{array}{l}0.0000 \\
0.0000\end{array}$ \\
\hline 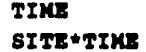 & $\begin{array}{r}9 \\
18\end{array}$ & $\begin{array}{r}9 \\
18\end{array}$ & & $\begin{array}{r}15.922211 \\
4.759549\end{array}$ & $\begin{array}{l}5.7053 \\
0.8490\end{array}$ & $\begin{array}{l}0.0000 \\
0.6403\end{array}$ \\
\hline
\end{tabular}


Table A-22.

Analysis of ground water viable counts on $1 \%$ PTYG (low nutrient) agar by site. Data was transformed using $\log _{10}(Y+1)$. Samples were taken between $5 / 19 / 89$ and $5 / 08 / 91(n=60)$. Variances were homogeneous as determined by the Hartley F-max test.

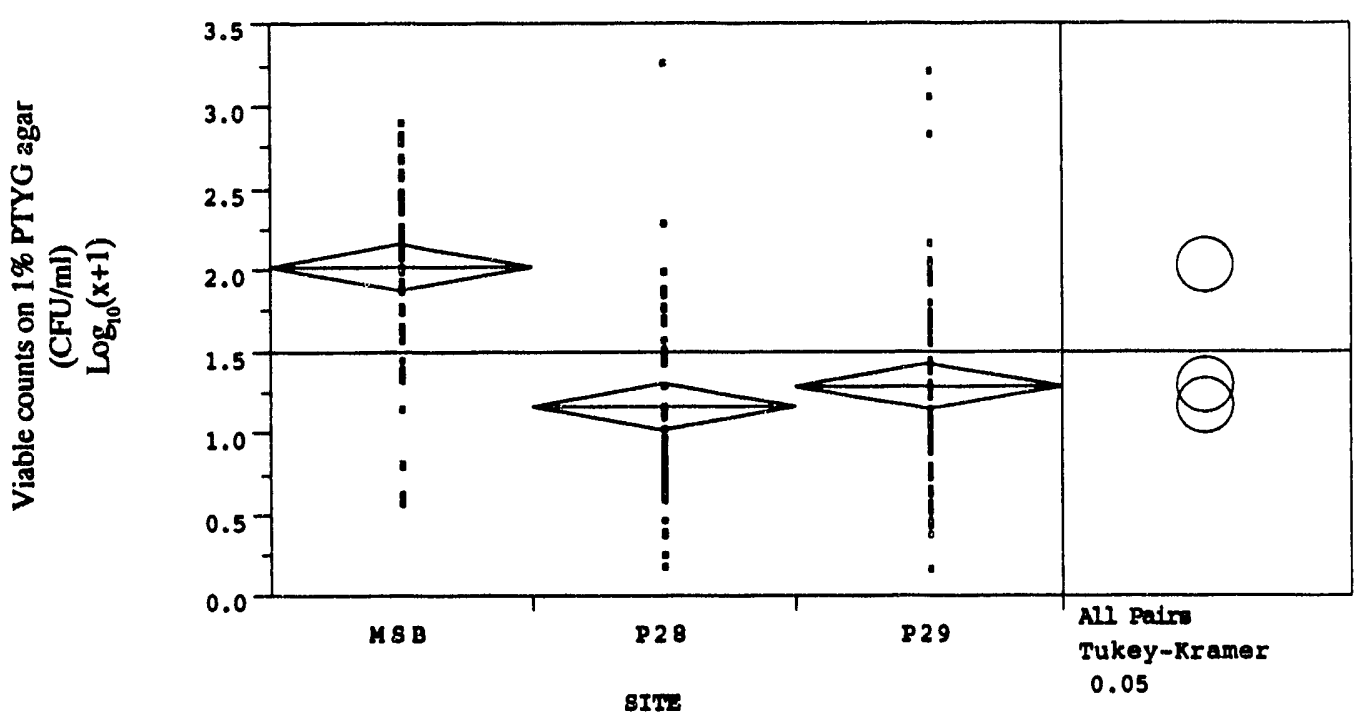

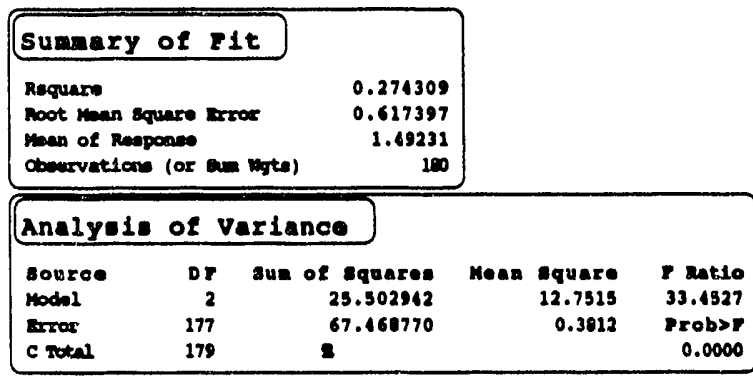

\begin{tabular}{lccc}
\hline He11 & Count & MeAn & Std DeY \\
MS B & 60 & 2.0191 & 0.5691 \\
P28 & 60 & 1.1627 & 0.6162 \\
P29 & 60 & 1.2952 & 0.6633 \\
\hline
\end{tabular}

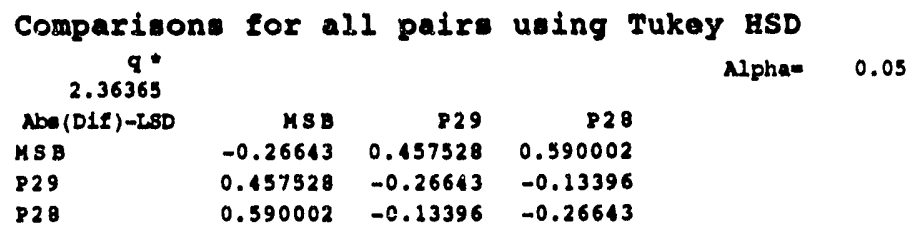

pooltive value ahou pair of man that are afgificantly different. 
Table A-23.

Analysis of ground water heterotrophic viable counts on 1\% PTYG (low nutrient) agar by well and time. Data was transformed using $\log _{10}(Y+1)$. Two factor analysis of variance was performed on samples taken between 6/ $19 / 89$ and 5/08/91 ( $n=20)$.

\begin{tabular}{|lr|}
\hline Summary of FIt \\
\hline Raguare & \\
Root Moan square Error & 0.813479 \\
Hean of Roupones & 0.313894 \\
Obeervations (or Sun Wgte) & 1.474919 \\
\hline
\end{tabular}

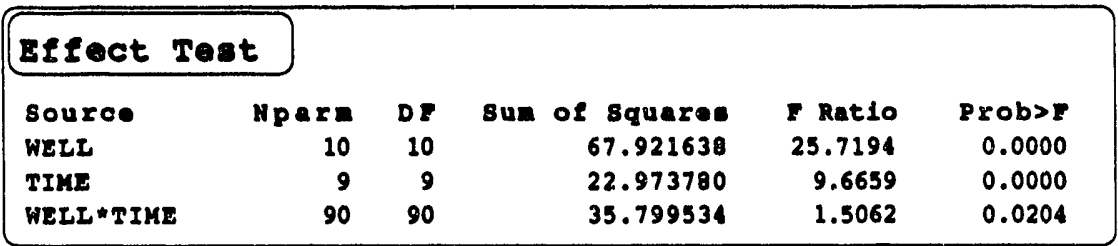


Table A-24.

Analysis of ground water viable counts on 1\% PTYG (low nutrient) agar by well. Data was transformed using $\log _{10}(Y+1)$. Samples were taken between 6 / $19 / 89$ and $5 / 08 / 91 \quad(n=20)$.

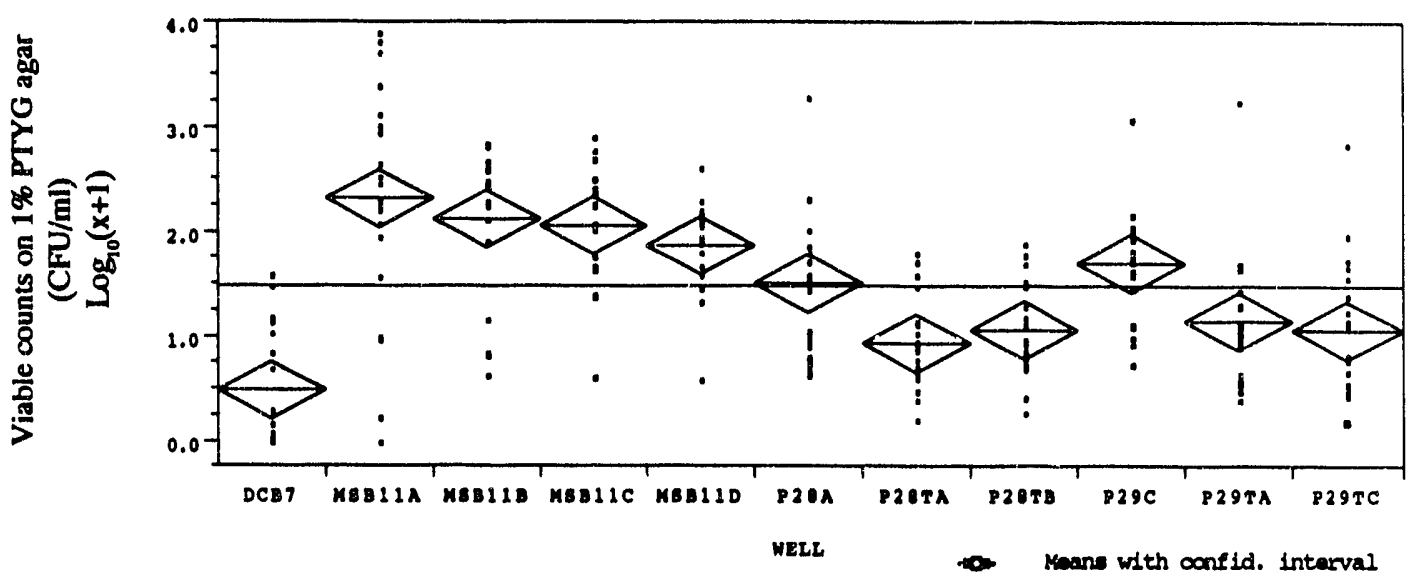

\begin{tabular}{lccc}
\hline HBIL N Number & MeAn & Std DeY \\
\hline DCB7 & 20 & 0.4879 & 0.5552 \\
P28TA & 20 & 0.9258 & 0.4382 \\
P29TC & 20 & 1.0477 & 0.6625 \\
P28TB & 20 & 1.0675 & 0.4380 \\
P29TA & 20 & 1.1428 & 0.6145 \\
P28A & 20 & 1.4948 & 0.7814 \\
P29C & 20 & 1.6949 & 0.5409 \\
MSB11D & 20 & 1.8720 & 0.4275 \\
MSB11C & 20 & 2.0598 & 0.5599 \\
MBB11B & 20 & 2.1255 & 0.6878 \\
MSB11A 20 & 2.3054 & 1.1141
\end{tabular}

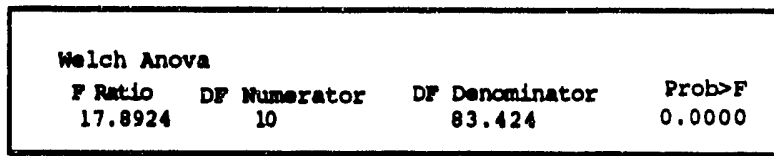

Comparison of equality of means as determined by Games and Howell (1976) method $(\alpha=0.05)$. Positive values represent significant differences.

\begin{tabular}{|c|c|c|c|c|c|c|c|c|c|c|c|}
\hline & DCB 7 & P205A & $8295 \mathrm{C}$ & P2858 & P29T & $828 A$ & $829 \mathrm{C}$ & M8B12D & MBBIIC & MBB $11 B$ & MSB $11 A$ \\
\hline DCB 7 & - & - & - & - & - & - & + & + & + & + & + \\
\hline P28TA & - & - & - & - & - & - & + & + & + & + & - \\
\hline $829 \mathrm{TC}$ & - & - & - & - & - & - & - & - & + & + & - \\
\hline P2858 & - & - & - & - & - & - & - & + & + & + & - \\
\hline R29 & - & - & - & - & - & - & - & - & + & + & - \\
\hline P28A & - & - & - & - & - & - & - & - & - & - & - \\
\hline $829 \mathrm{C}$ & + & + & - & - & - & - & - & - & - & - & - \\
\hline$M S B \perp 1 D$ & + & + & - & + & - & - & - & - & - & - & - \\
\hline HSB $11 \mathrm{C}$ & + & + & + & + & + & - & - & - & - & - & - \\
\hline M8B $11 \mathrm{~B}$ & + & + & + & + & + & - & - & - & - & - & - \\
\hline MSB $11 A$ & + & - & - & - & - & - & - & - & - & - & - \\
\hline
\end{tabular}




\section{Table A-25.}

Analysis of ground water heterotrophic viable counts on PTYG agar by site and time. Two factor analysis of variance was performed on samples taken between $2 / 28 / 90$ and $2 / 11 / 91(n=30)$.

\begin{tabular}{|c|c|}
\hline Summary of pit & \\
\hline Raquare & 0.39096 \\
\hline Root Moan square Error & 0.524369 \\
\hline Mean of Roeponee & 1.294071 \\
\hline Observation (or sum Wgte) & so \\
\hline
\end{tabular}

\begin{tabular}{|c|c|c|c|c|c|c|}
\hline source & Apara & DE & sun & of squares & I Rat10 & Prob $>$ E \\
\hline SIts & 2 & 2 & & 10.866060 & 19.7591 & 0.0000 \\
\hline TIME & 4 & 4 & & 0.958405 & 0.8714 & 0.4852 \\
\hline SITE*TIME & 8 & 8 & & 1.413539 & 0.6426 & 0.7395 \\
\hline
\end{tabular}


Table A-26.

Analysis of ground water heterotrophic viable counts on PTYG (high nutrient) agar by site. Data was transformed using $\log _{10}(Y+1)$. Samples were taken between $2 / 28 / 90$ and $3 / 15 / 91(n=30)$.

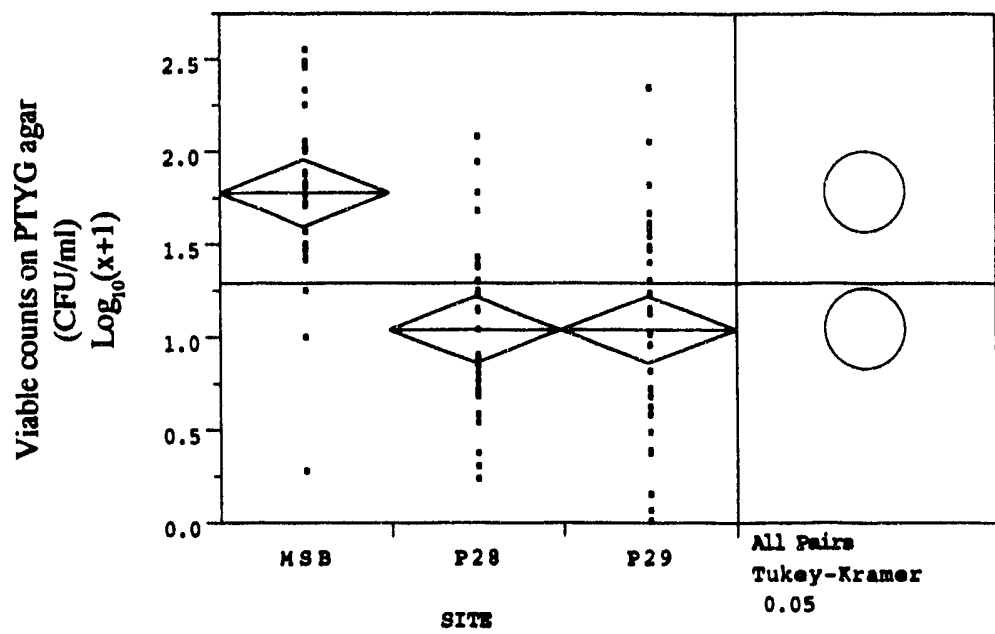

\begin{tabular}{lccc}
\hline Well & Number & Mean & Std Dev \\
\hline MSB & 30 & 1.7855 & 0.4610 \\
P28 & 30 & 1.0502 & 0.4715 \\
P29 & 30 & 1.0466 & 0.5984 \\
\hline
\end{tabular}

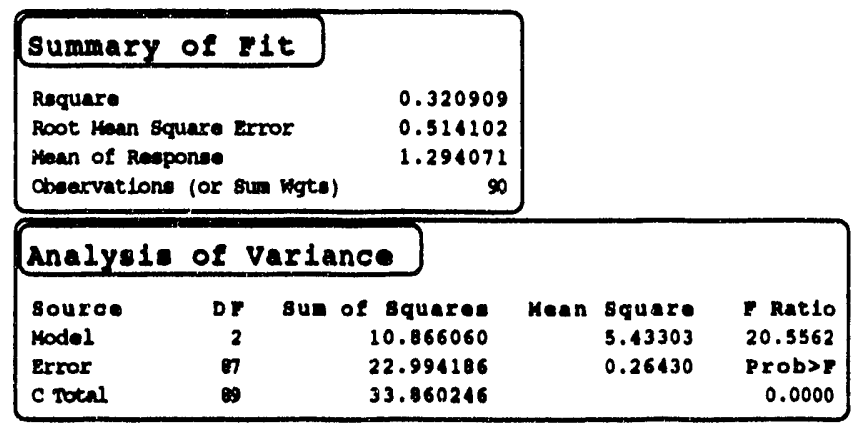

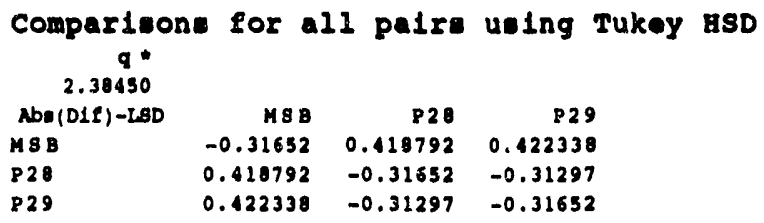


Table A-27.

Analysis of ground water heterotrophic viable counts on PTYG agar by well and time. Two factor analysis of variance was performed on samples taken between $2 /$ $28 / 90$ and $2 / 11 / 91$.

\begin{tabular}{|c|c|}
\hline Summary of $\mathrm{F} 1 \mathrm{t}$ & \\
\hline Requare & 0.810768 \\
\hline Root Man Square Error & 0.424259 \\
\hline Mean of Rosponse & 1.253913 \\
\hline Observationa (ar sum Ngto) & 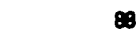 \\
\hline
\end{tabular}

\begin{tabular}{|lrrrrrr|}
\hline Effect TeEt & & & & \\
Source & Npara & Dr & Sur of Squeres & F Rat10 & Prob>F \\
WELI & 10 & 10 & 24.963289 & 13.8688 & 0.0000 \\
TIME & 3 & 3 & 0.547035 & 1.0131 & 0.3960 \\
WELI*TIME & 30 & 30 & 8.422419 & 1.5597 & 0.0880 \\
\hline
\end{tabular}


Table A-28.

Analysis of ground water heterotrophic viable counts on PTYG (high nutrient) agar by well. Data was transformed using $\log _{10}(Y+1)$. Samples were taken between $2 / 28 / 90$ and $2 / 11 / 91(n=8)$. Distribution was normal as determined by the Shapiro-Wilk W test (Shapiro et al., 1968; Zar, 1984).

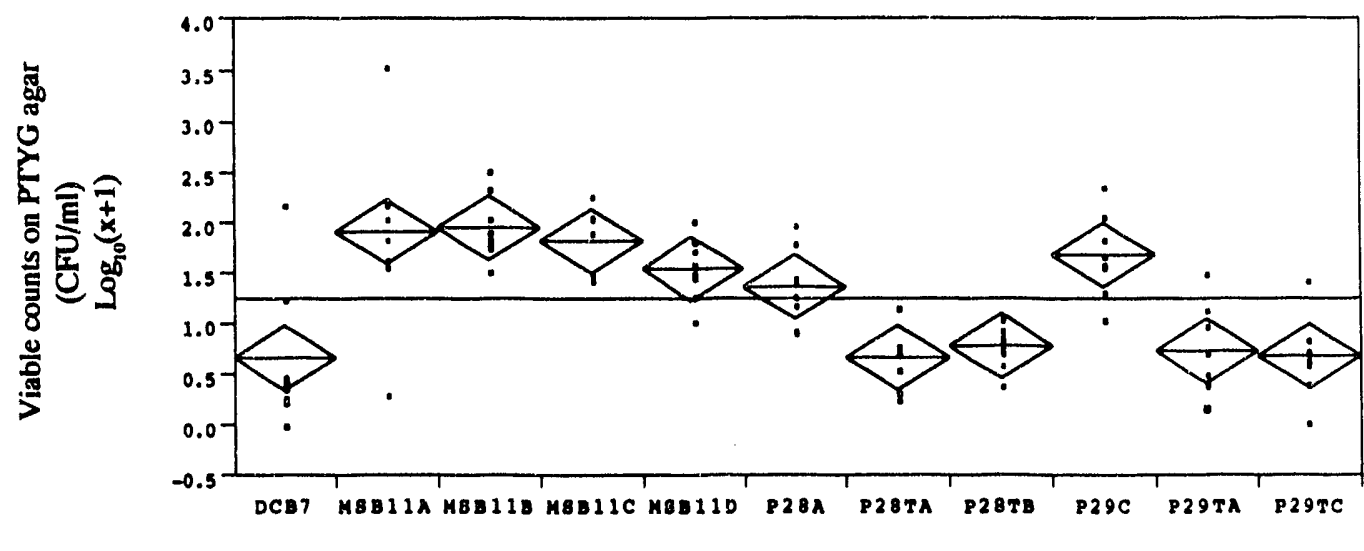

\begin{tabular}{lcccc}
\hline Hell & Number & Mesan & Yariance \\
DCB7 & 8 & 0.655 & 0.509 \\
MSB11A & 8 & 1.918 & 0.805 \\
MSB11B & 8 & 1.961 & 0.107 \\
MSB11C & 8 & 1.830 & 0.099 \\
MSB11D & 8 & 1.551 & 0.100 \\
P28A & 8 & 1.362 & 0.144 \\
P28TA & 8 & 0.656 & 0.081 \\
P28TB & 8 & 0.768 & 0.042 \\
P29C & 8 & 1.687 & 0.171 \\
P29TA & 8 & 0.728 & 0.200 \\
P29TC & 8 & 0.678 & 0.154
\end{tabular}

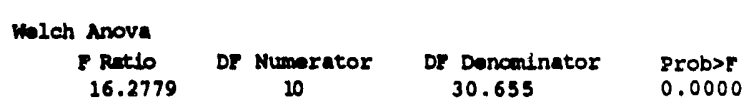

Comparison of equality of means as determined by Games and Howell (1976) nethod $(\alpha=0.05)$. Positive values represent significant differences.

\begin{tabular}{|c|c|c|c|c|c|c|c|c|c|c|c|}
\hline & DCB 7 & P20TA & P29TC & P29TA & P2OTE & $P 28 A$ & MS8110 & P29C & MSBi1C & K8B11A & MSO11B \\
\hline DCB 7 & - & - & - & - & - & - & - & - & - & - & - \\
\hline P20XA & - & - & - & - & - & - & + & + & + & - & + \\
\hline P29TC & - & - & - & - & - & - & - & - & + & - & + \\
\hline P28TA & - & - & - & - & - & - & - & - & + & - & + \\
\hline р28TB & - & - & - & - & - & - & + & + & + & - & + \\
\hline P28A & - & - & - & - & - & - & - & - & - & - & - \\
\hline MSB110 & - & + & - & - & + & - & - & - & - & - & - \\
\hline P29C & - & + & - & - & + & - & - & - & - & - & - \\
\hline M8B11C & - & + & + & $\downarrow$ & + & - & - & - & - & - & - \\
\hline KSBIIA & - & - & - & - & - & - & - & - & - & - & - \\
\hline H8B11B & - & + & + & + & + & - & - & - & - & - & - \\
\hline
\end{tabular}


Table A-29.

Analysis of the percentage of active cells (as determined by acridine orange) by site and time. Data was transformed using arc sin square root. Two factor analysis of variance was performed on samples taken between 6/19/89 and 5/ $08 / 91(n=60)$.

\begin{tabular}{|lr|}
\hline Summary of Fit \\
\hline Requare & 0.426259 \\
Root Maan square Error & 0.204545 \\
Mean of Reaponse & 0.960232 \\
Obeervations (or sum Wgta) & 100 \\
\hline
\end{tabular}

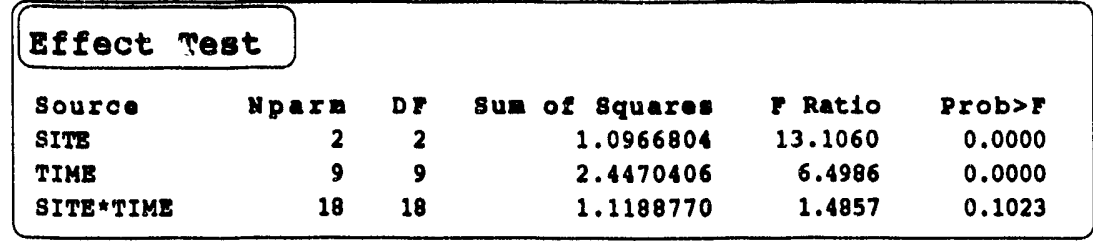


Table A-30.

Analysis of the percentage of active cells (as determined by acridine orange) by site. Data was transformed using arc sin square root. Samples were taken between $6 / 19 / 89$ and $5 / 08 / 91(n=60)$. Variances were homogeneous as determined by the Hartley F-max test.

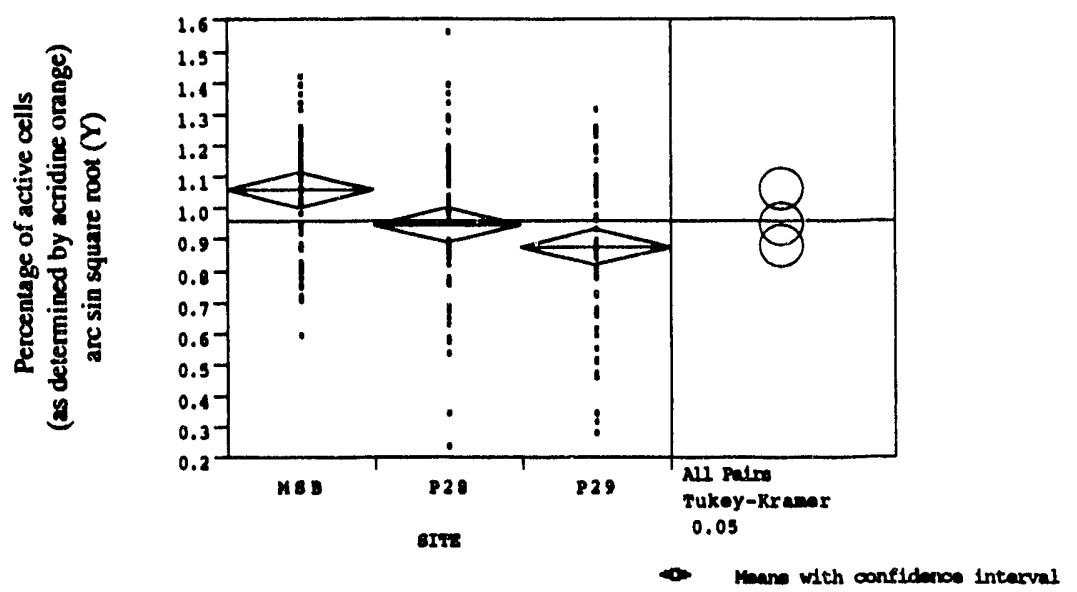

\begin{tabular}{lccc}
\hline Hell & Count & Mean & Std Dey \\
\hline M B & 60 & 1.062 & 0.192 \\
P 28 & 60 & 0.946 & 0.255 \\
P29 & 60 & 0.873 & 0.255
\end{tabular}

\begin{tabular}{|c|c|c|c|}
\hline \multicolumn{2}{|l|}{ summary of rit } & & \\
\hline 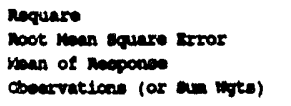 & $\begin{array}{r}0.10026 \\
0.235803 \\
0.960232 \\
200\end{array}$ & & \\
\hline \multicolumn{4}{|c|}{ Analyole of Varlanon } \\
\hline $\begin{array}{l}D \text { D } \\
2 \\
177 \\
179\end{array}$ & $\begin{array}{r}\text { gqueres } \\
1.096680 \\
9.041736 \\
10.930416\end{array}$ & $\begin{array}{r}\text { Moen squere } \\
0.546340 \\
0.055603\end{array}$ & $\begin{array}{r}\text { rat10 } \\
9.0617 \\
p 20 b>8 \\
0.0001\end{array}$ \\
\hline
\end{tabular}

$\begin{array}{crrr}\text { Comparisons for all pairs using Tu } \\ \text { 9* } \\ \begin{array}{rrrr}2.36365 \\ \text { Abs(Dif)-LSD }\end{array} & \text { HSB } & \text { P28 } & \text { P29 } \\ \text { MSB } & -0.10176 & 0.014518 & 0.087821 \\ \text { P28 } & 0.014518 & -0.10176 & -0.02845 \\ \text { P29 } & 0.087821 & -0.02845 & -0.10176\end{array}$

poeitive valum whow paire of means that are significantly different. 


\section{Table A-31.}

Analysis of the percentage of active cells (as determined by acridine orange) by well and time. Data was transformed using arc sin square root. Two factor analysis of variance was performed on samples taken between 6/19/89 and 5/ $08 / 91(n=20)$.

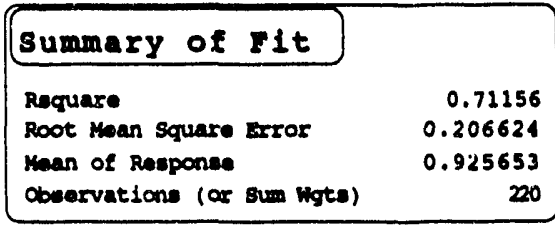

\begin{tabular}{|c|c|c|c|c|c|c|}
\hline souroe & upara & D F & sum & of squeres & Fat 10 & Prob>P \\
\hline WELL & 10 & 10 & & 4.8772895 & 11.4240 & 0.0000 \\
\hline TIME & 9 & 9 & & 2.1694398 & 5.6460 & 0.0000 \\
\hline WELL *TIME & 90 & 90 & & 4.5386306 & 1.1812 & 0.2019 \\
\hline
\end{tabular}


Table A-32.

Analysis of the percentage of active cells (as determined by acridine orange) by well. Data was transformed using arc sin square root. Samples were taken between $6 / 19 / 89$ and $5 / 08 / 91(n=20)$. Variances were homogeneous as determined by the Hartley F-max test.

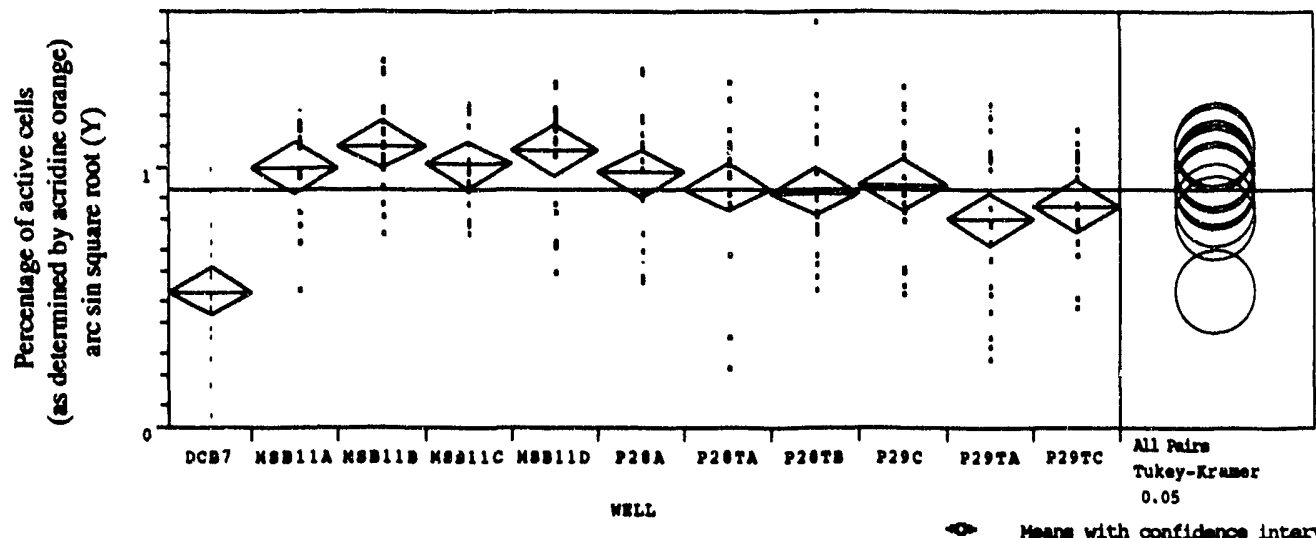

\begin{tabular}{lccc}
\hline Well & Count & Mean & Std Dev \\
DCB7 & 20 & 0.530 & 0.246 \\
MSB11A & 20 & 1.010 & 0.192 \\
MSB11B & 20 & 1.096 & 0.181 \\
MSB11C & 20 & 1.017 & 0.173 \\
MSB11D & 20 & 1.074 & 0.219 \\
P28A & 20 & 0.989 & 0.238 \\
P28TA & 20 & 0.934 & 0.267 \\
P28TB & 20 & 0.914 & 0.265 \\
P29C & 20 & 0.940 & 0.237 \\
P29TA & 20 & 0.815 & 0.318 \\
P29TC & 20 & 0.863 & 0.190 \\
\hline
\end{tabular}

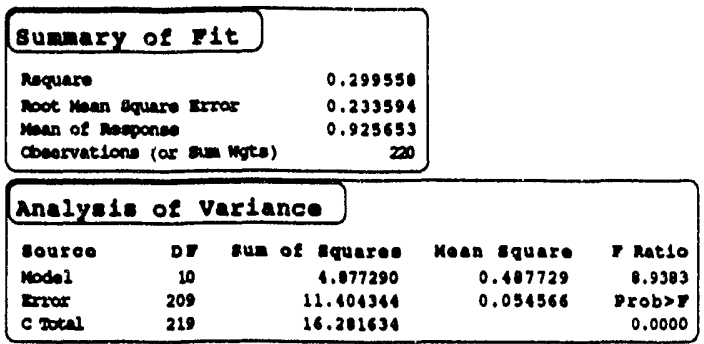

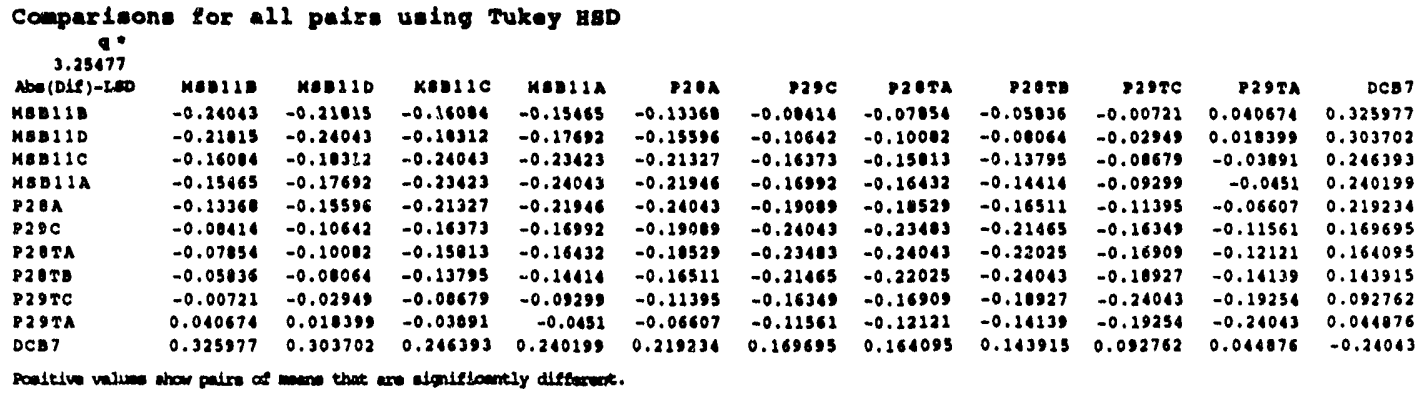


Table A-33.

Comparison of densities for heterotrophic viable counts on PTYG (high nutrient) and $1 \%$ PTYG (low nutrient) media.

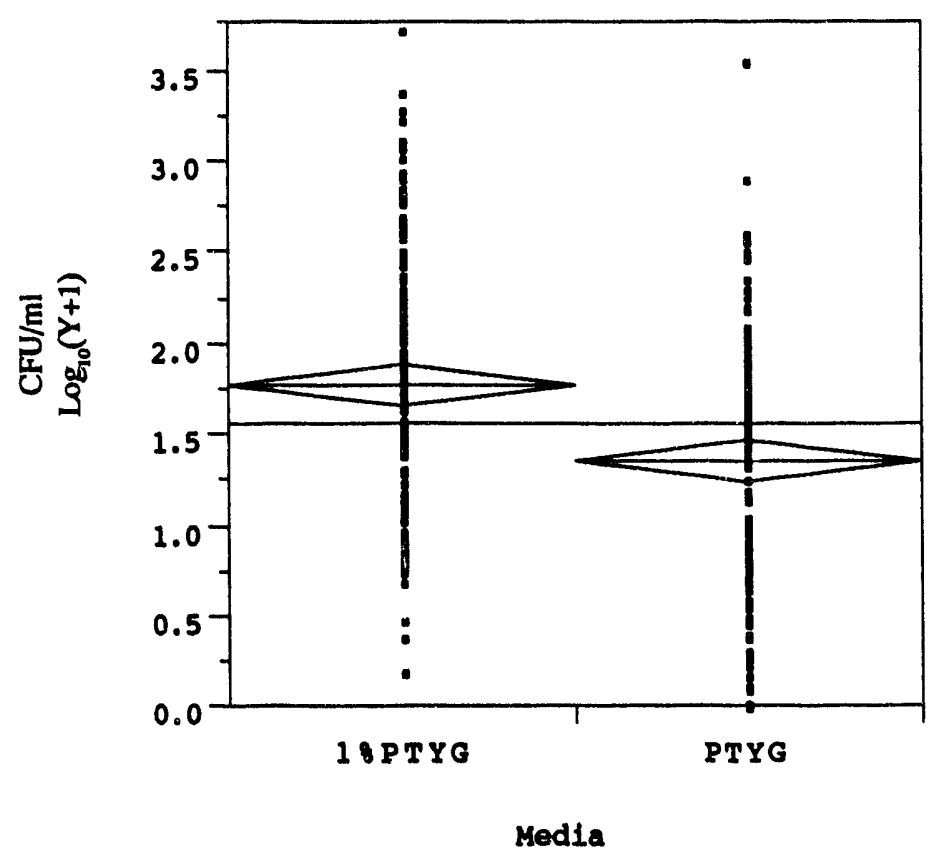

\begin{tabular}{lccc}
\hline Media & count & Mean & Std DeY \\
I8PTYG & 132 & 1.7767 & 0.7179 \\
PTYG & 132 & 1.3529 & 0.7010
\end{tabular}

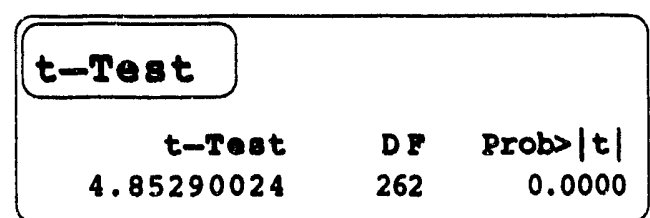


Table A-34.

Comparison of densities of carbohydrate, carboylic acid and amino acid utilizers. Data was transformed using $\log _{10}(Y+1)$.

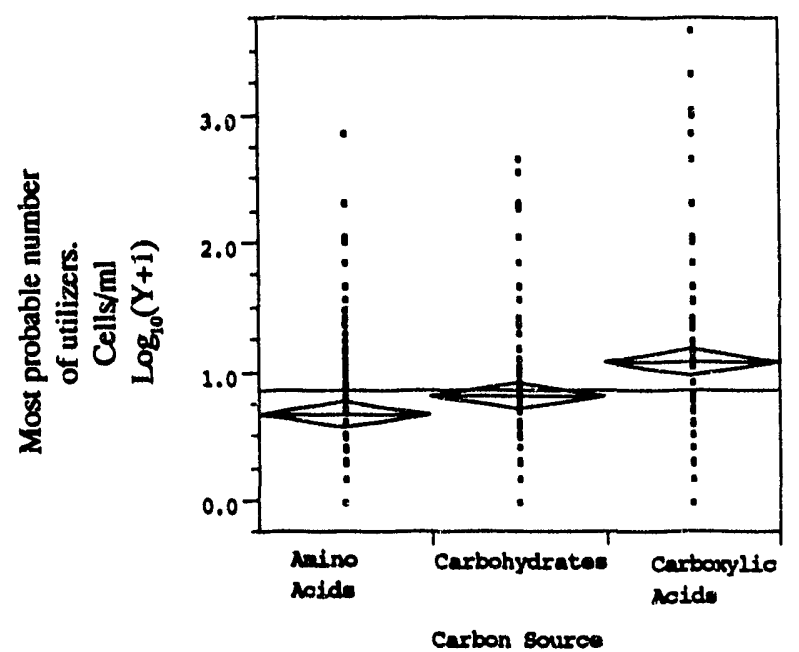

\begin{tabular}{|c|c|c|c|}
\hline Carbon souren Groulpal & Count. & Man & Sted Dey \\
\hline Amino Acids & 180 & 0.669 & 0.665 \\
\hline carbohydrate & 180 & 0.818 & 0.712 \\
\hline Cantoprylte actoly & 180 & 1.070 & 0.795 \\
\hline
\end{tabular}

\section{Welch ANOVA}

$\begin{array}{lccc}\text { F Ratio } & \text { DF Numerator } & \text { DF Denconinator } & \text { Prob>F } \\ 13.5082 & 2 & 356.18 & 0.0000\end{array}$

Comparison of equality of means for densities of amino acid utilizing bacteria as determined by Games and Howell (1976) method $(a=.05)$.

$\begin{array}{lccc} & \text { Amino Acids } & \text { Carbohydrate } & \text { Carboxylic acids } \\ \text { Amino Acids } & - & - & + \\ \text { Carbohydrate } & - & - & + \\ \text { Carboxylic Acids } & + & + & -\end{array}$


Table A-35.

Comparison of densities of amino acid utilizers between wells. Data was transformed using $\log _{10}(Y+1)$.

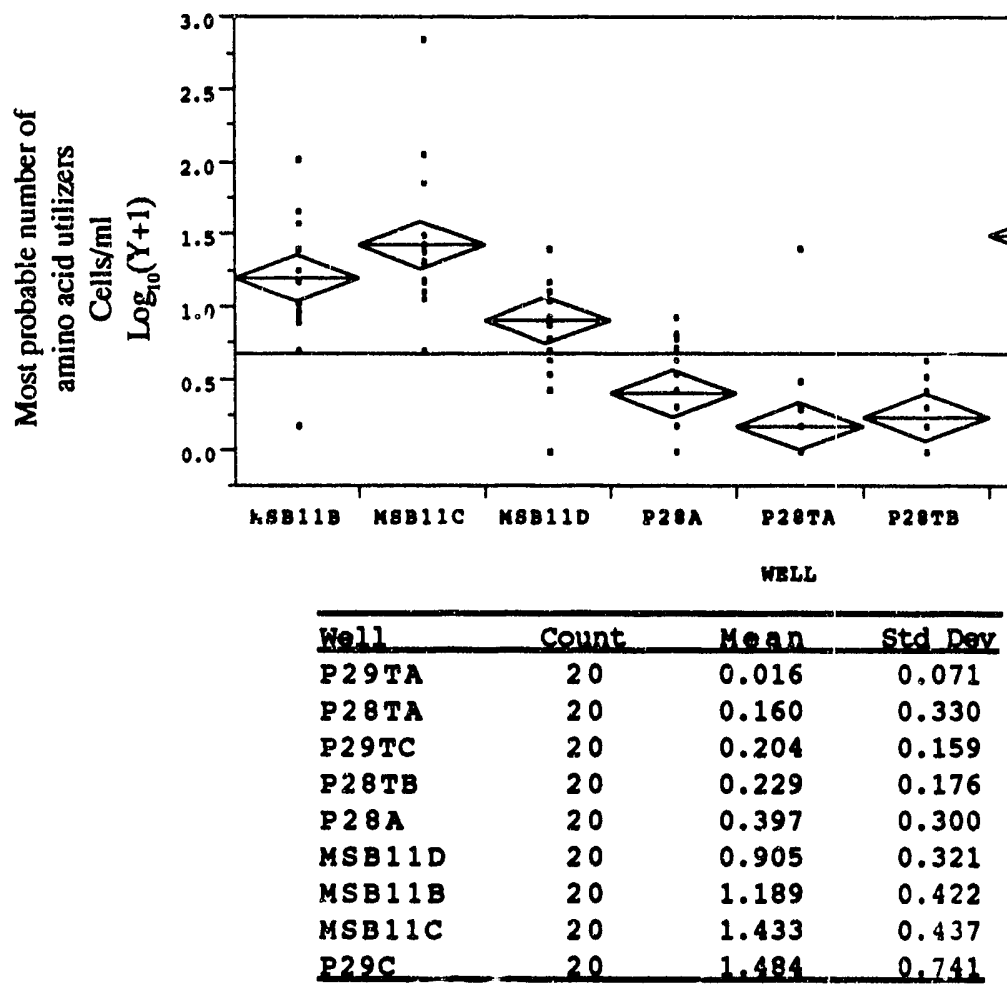

\section{Welch ANOVA}

$\begin{array}{cccc}\text { F Rato } & \text { DF Numerator } & \text { DF Denoulnitor } & \text { Probs } \\ 65.4361 & 8 & 68.176 & 0.0000\end{array}$

Comparison of equality of means for densities of amino acid utilizing bacteria as determined by Games and Howell (1976) method $(a=.05)$.

\begin{tabular}{|c|c|c|c|c|c|c|c|c|c|}
\hline & P29TA & P28тx & R297C & P285: & $828 A$ & Maอ D D & MBB11B & $M 8 B 11 C$ & P29C \\
\hline P29TA & - & - & + & + & + & + & + & + & + \\
\hline P28тA & - & - & - & - & - & + & + & + & + \\
\hline P29TC & + & - & - & - & - & + & + & + & + \\
\hline P28T3 & + & - & - & - & - & + & + & + & + \\
\hline P 28X & + & - & - & - & - & + & + & + & $\dot{r}$ \\
\hline KSBIID & + & + & + & + & + & - & - & - & - \\
\hline M8B11B & + & + & + & + & + & - & - & - & - \\
\hline MSBIIC & + & + & + & + & + & - & - & - & - \\
\hline P29C & + & + & + & + & + & - & - & - & - \\
\hline
\end{tabular}


Table A-36.

Comparison of densities of carbohydrate utilizers between wells. Data was transformed using $\log _{10}(Y+1)$.

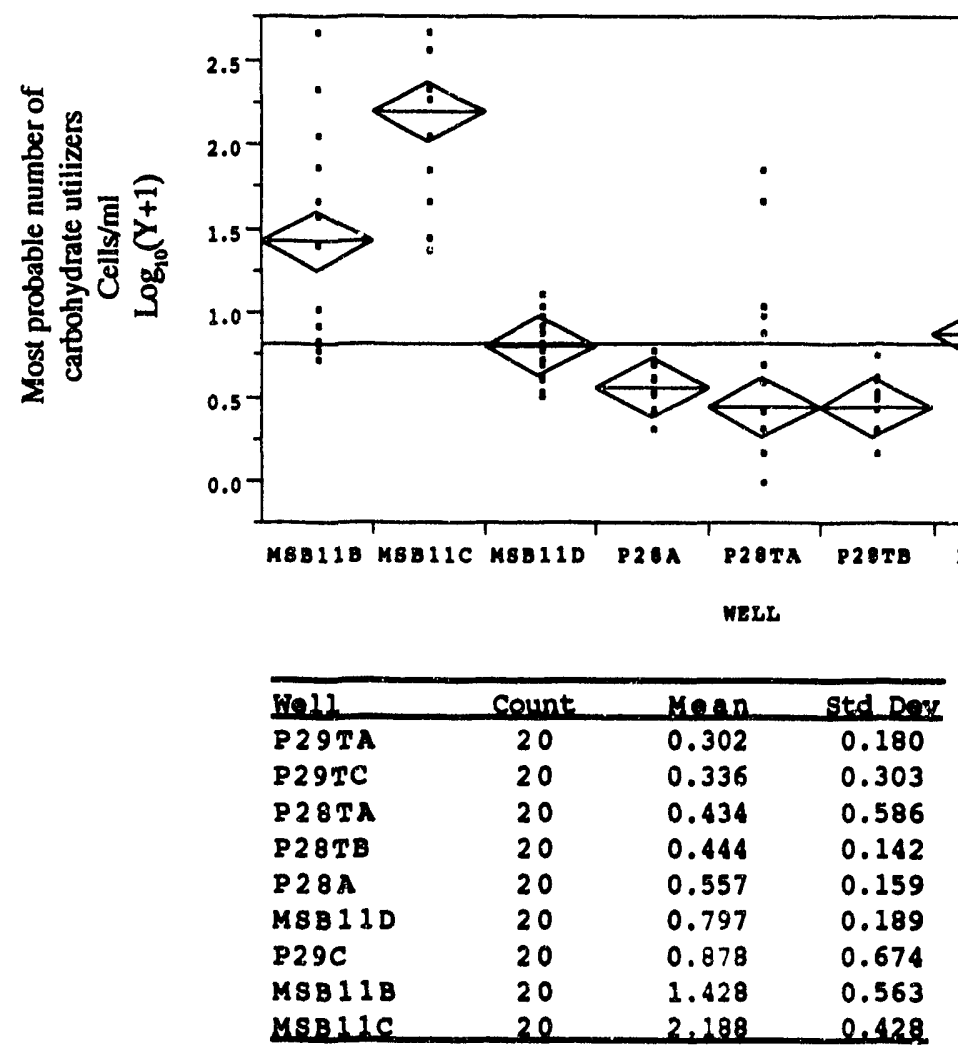

\begin{tabular}{|c|c|c|c|}
\hline \multicolumn{4}{|c|}{ Welch ANOVA } \\
\hline F Ratio & DF Mumorator & DE Denominator & Prob>F \\
\hline 51.4053 & 8 & 70.378 & 0.0000 \\
\hline
\end{tabular}

Comparison of equality or means for densities of carboxylic acid utilizing bacteria as determined by Games and Howell (1976) method ( $a=.05)$.

\begin{tabular}{|c|c|c|c|c|c|c|c|c|c|}
\hline & $8292 x$ & $8295 C$ & P20ra & P2ETB & P2\&A & MAB 110 & P29C & ИBB $12 B$ & M3BIIC \\
\hline P29TA & - & - & - & - & - & + & - & + & + \\
\hline P29TC & - & - & - & - & - & + & - & + & + \\
\hline P2BTA & - & - & - & - & - & - & - & + & + \\
\hline P28TB & - & - & - & - & - & + & - & + & + \\
\hline P 28A & + & - & - & - & - & - & - & + & + \\
\hline MSB 110 & + & + & & + & - & - & - & - & + \\
\hline P29C & - & - & - & - & - & - & - & - & + \\
\hline MSB $11 B$ & + & + & + & + & + & - & - & - & + \\
\hline MSBIIC & + & + & + & + & + & + & + & + & - \\
\hline
\end{tabular}




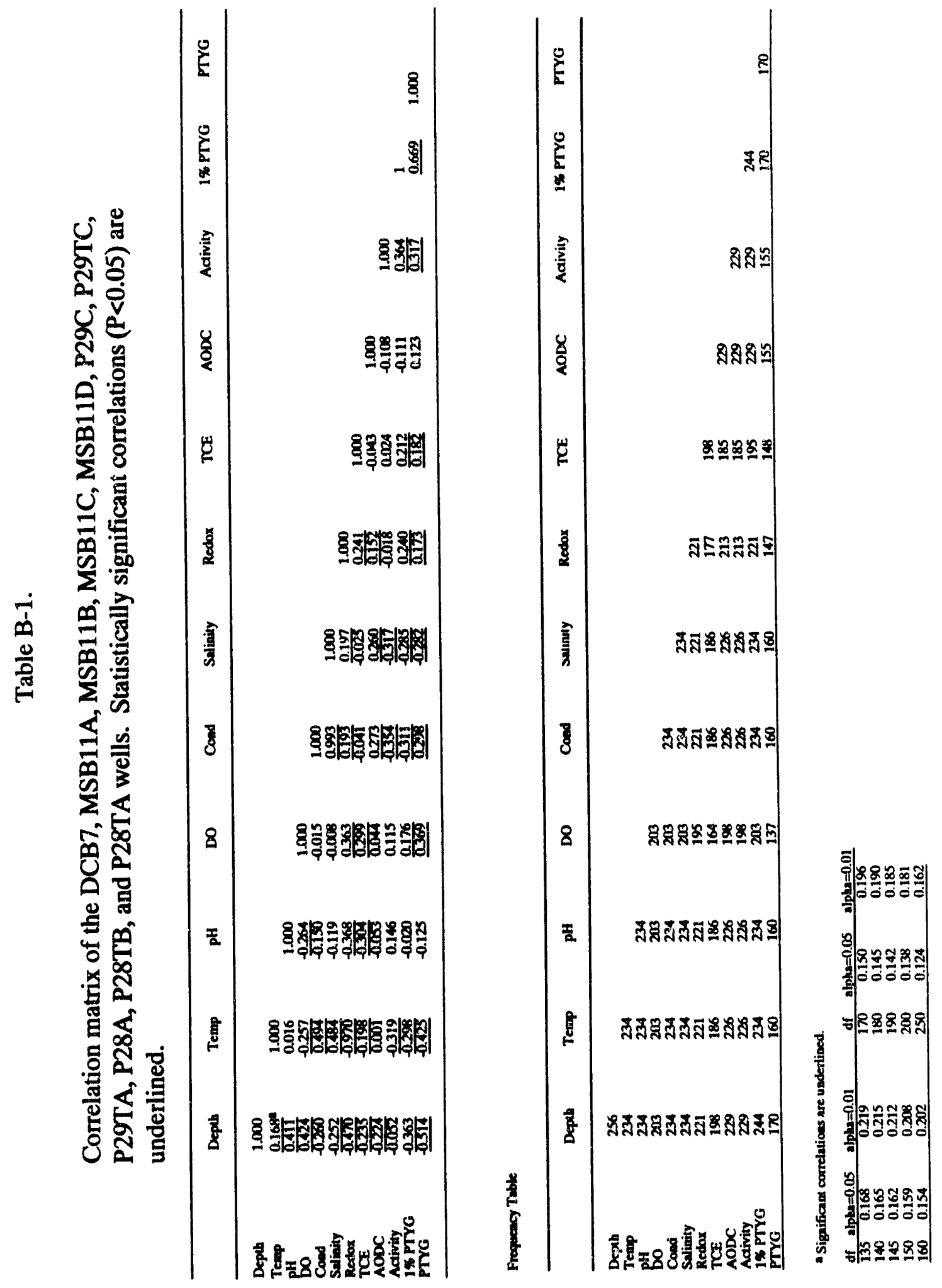



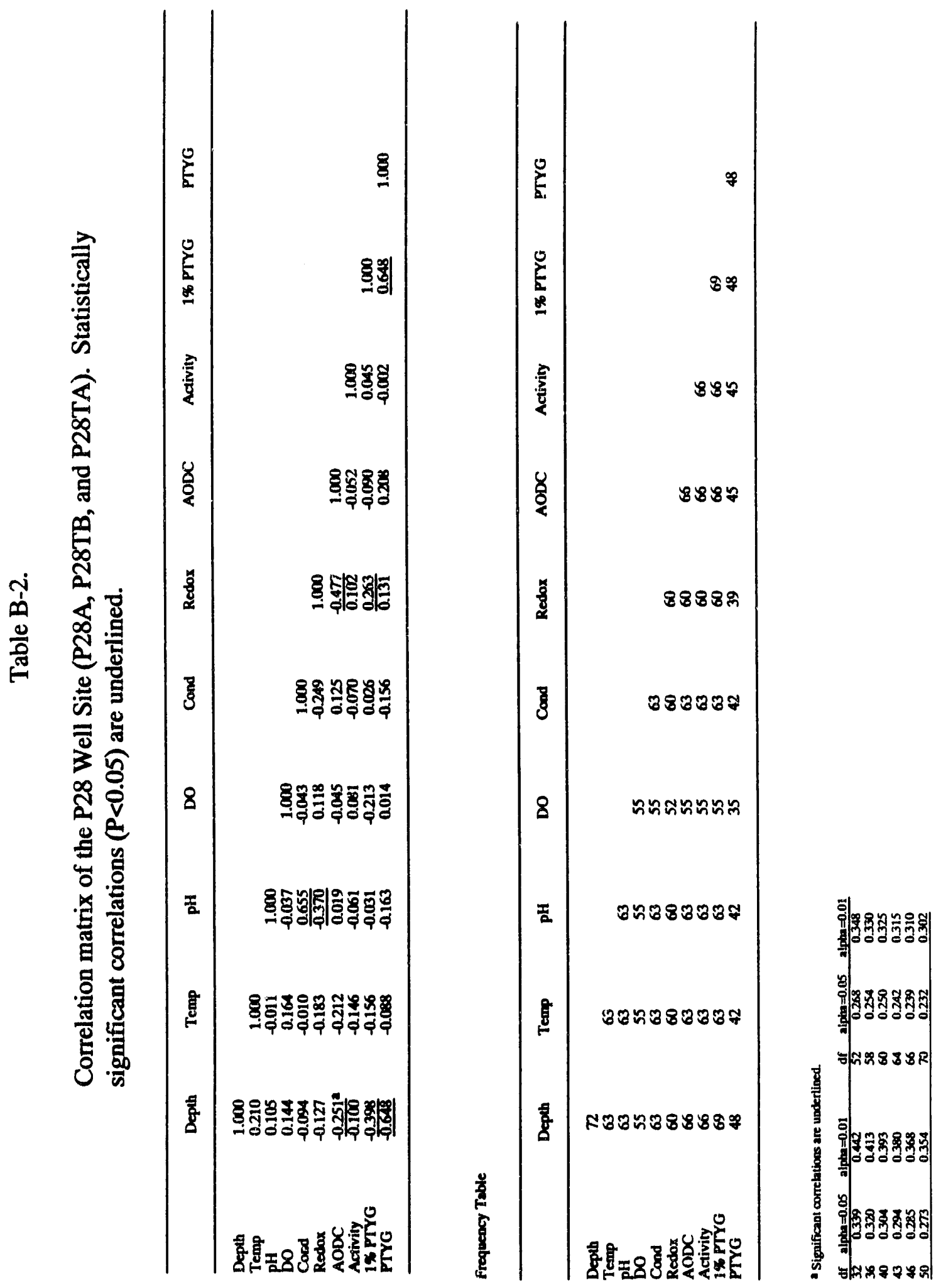


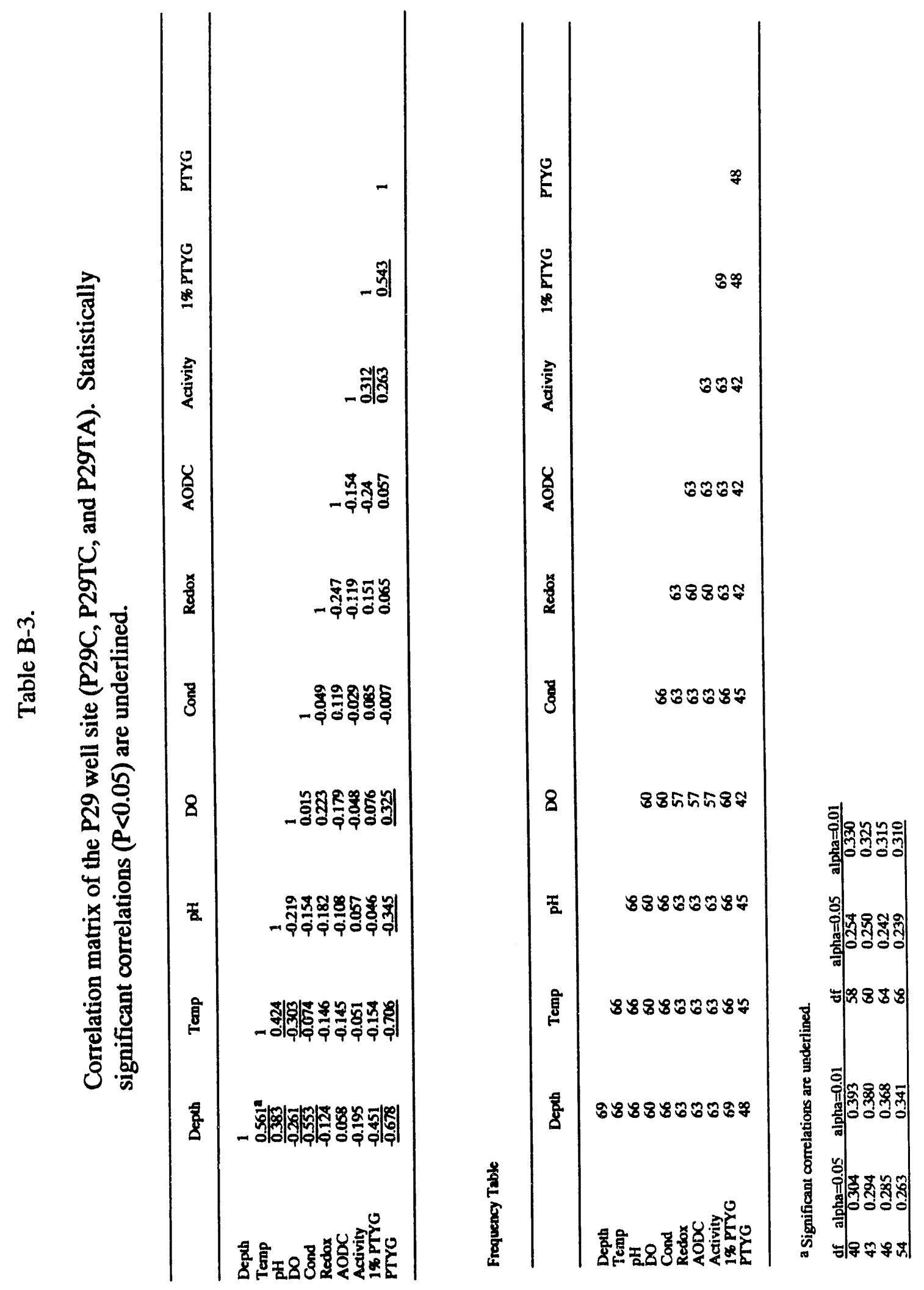




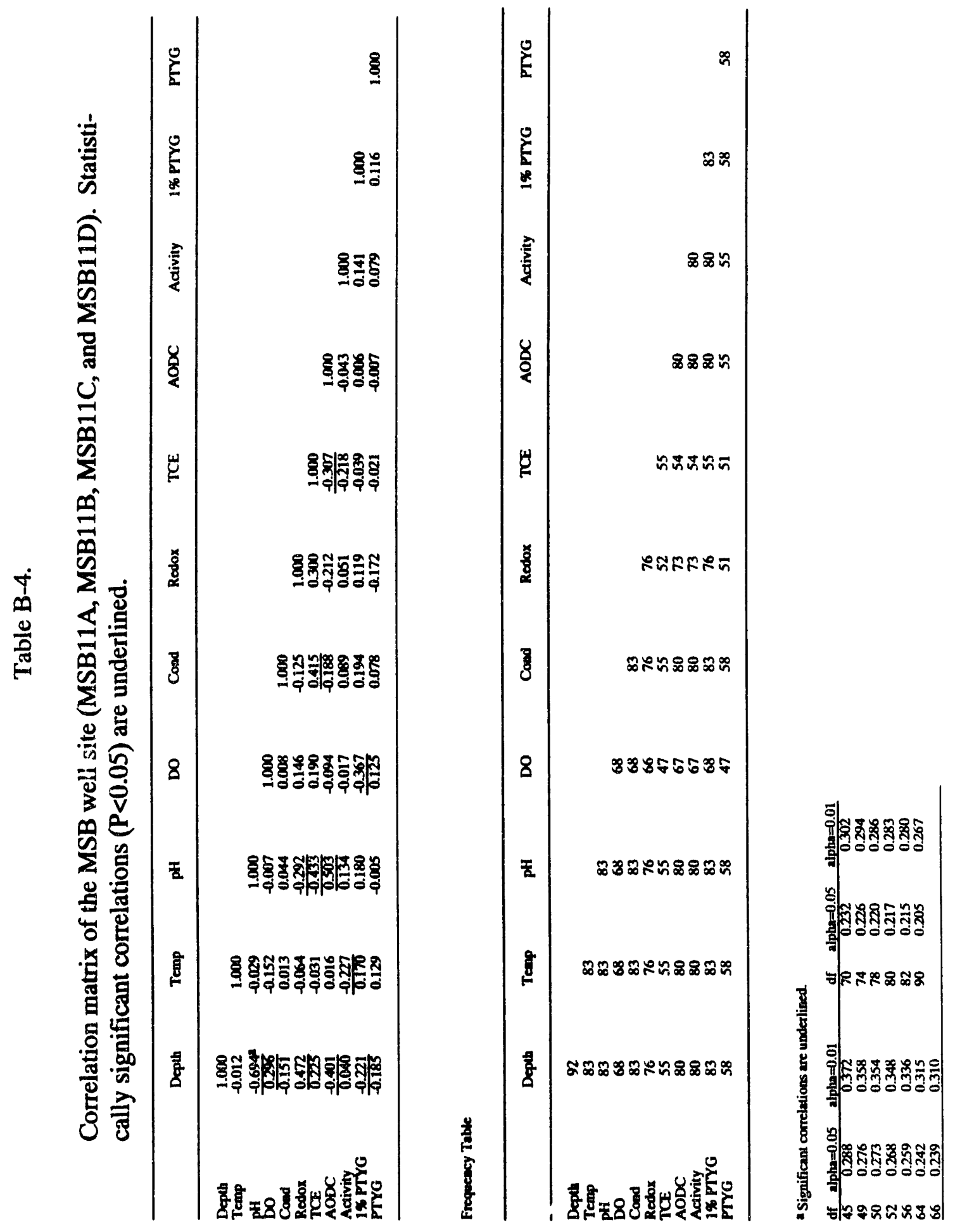




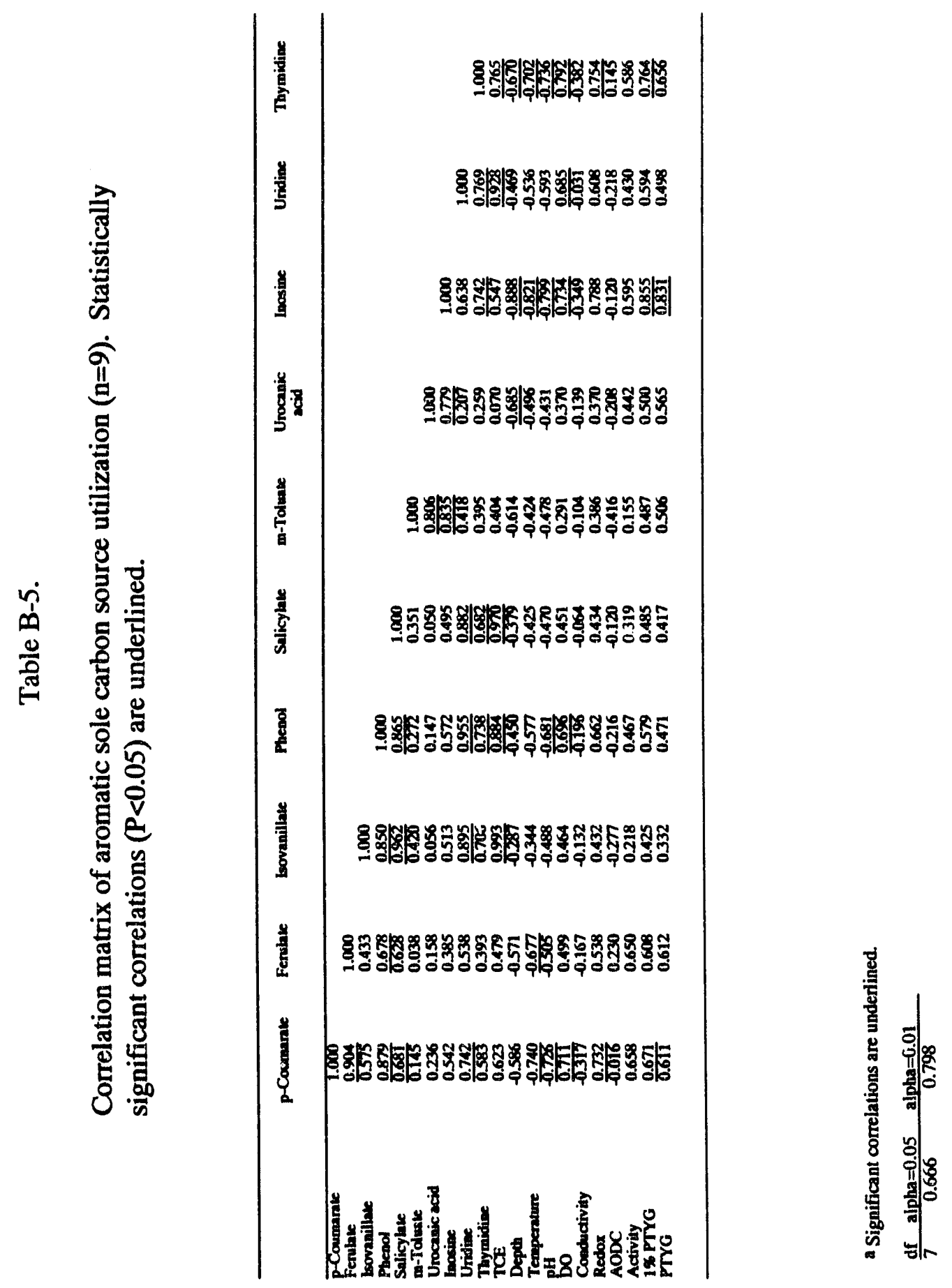




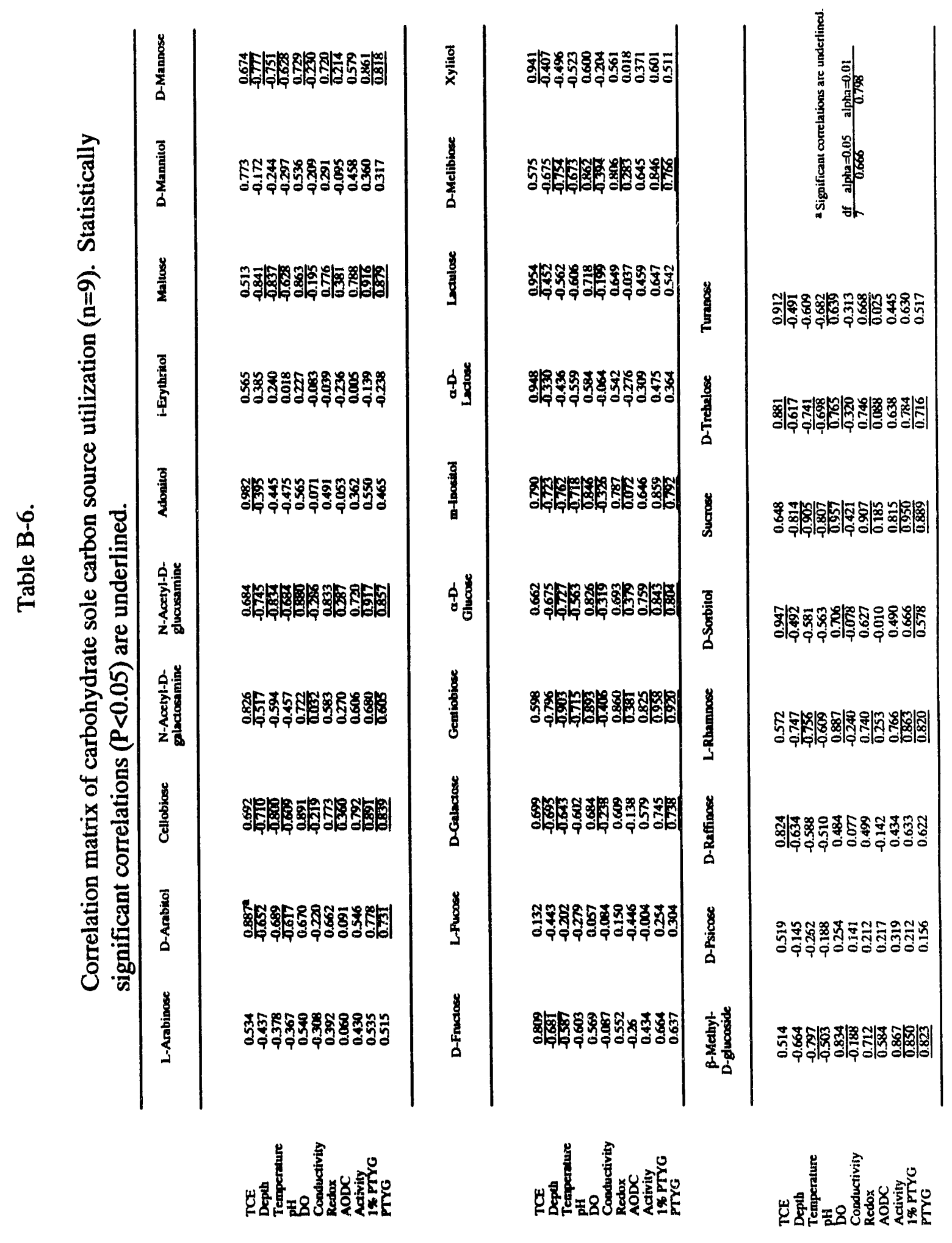




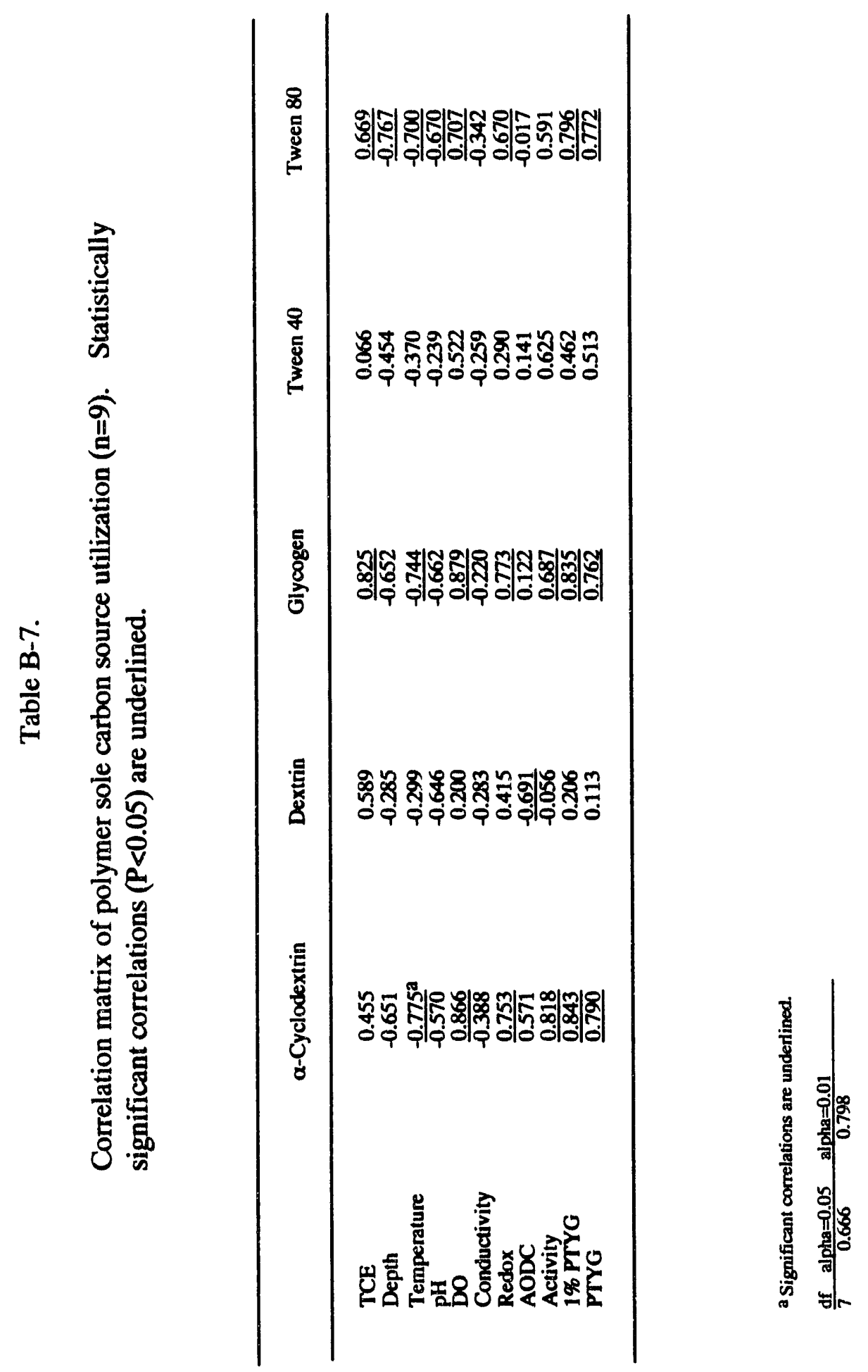




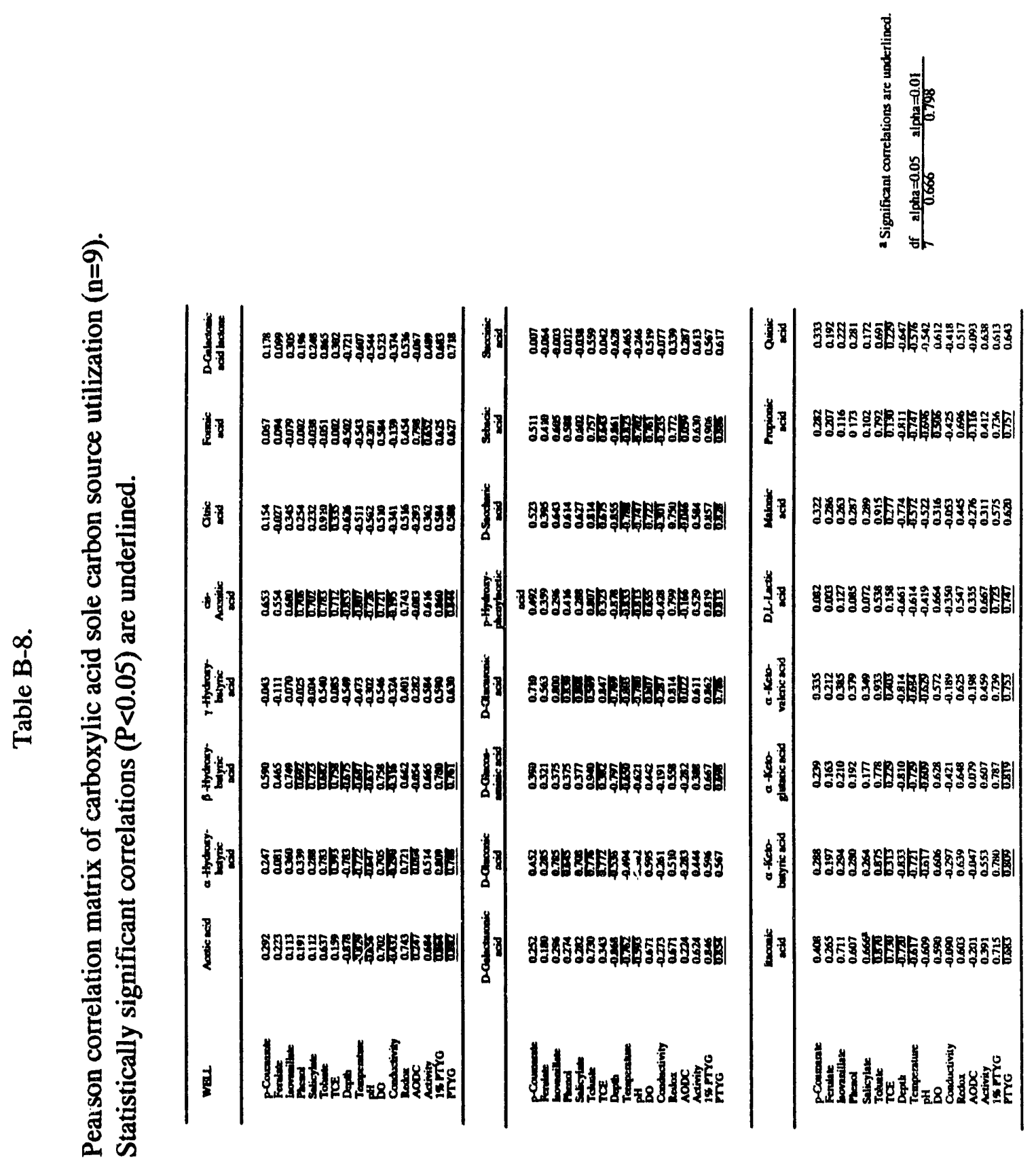



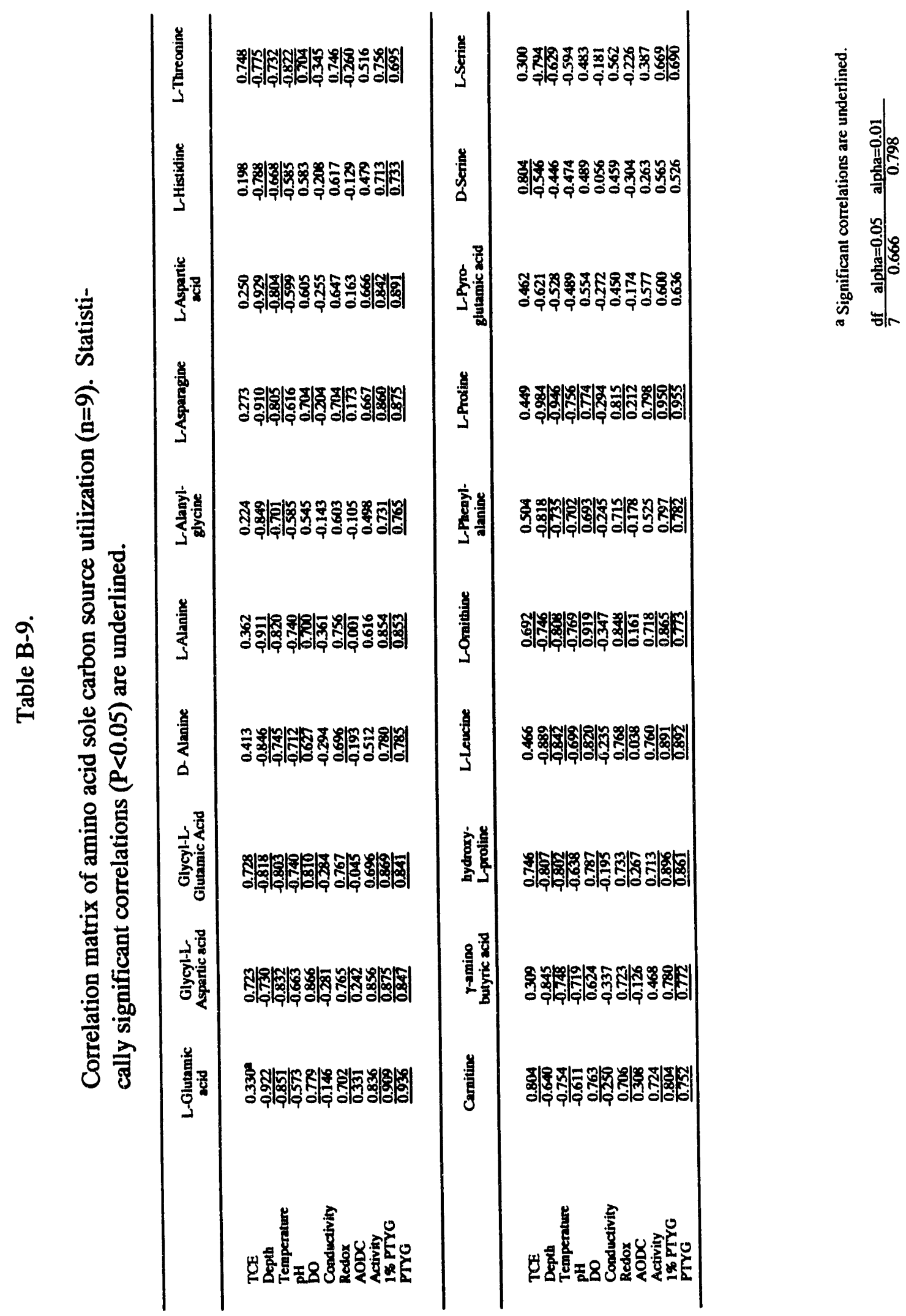

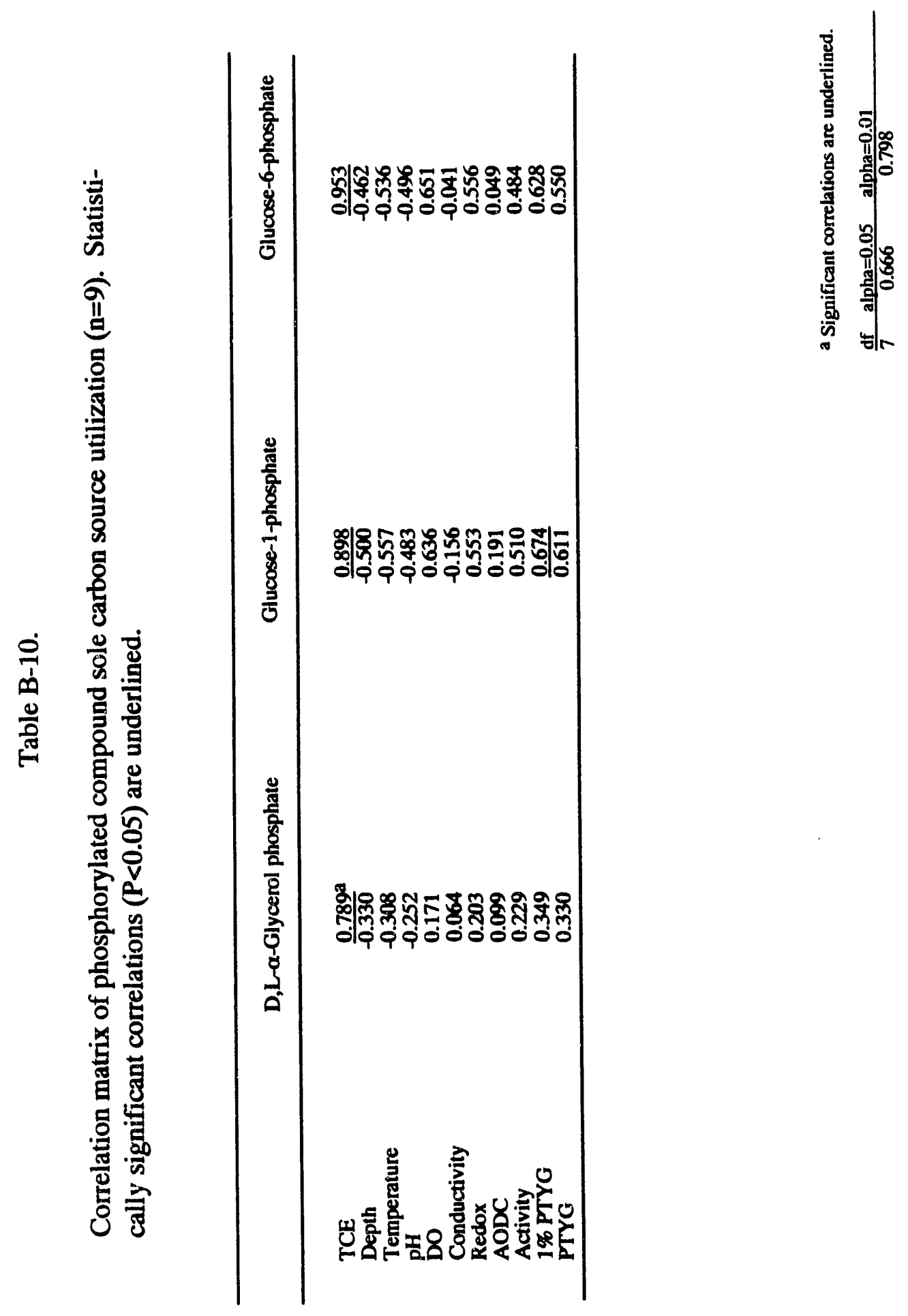


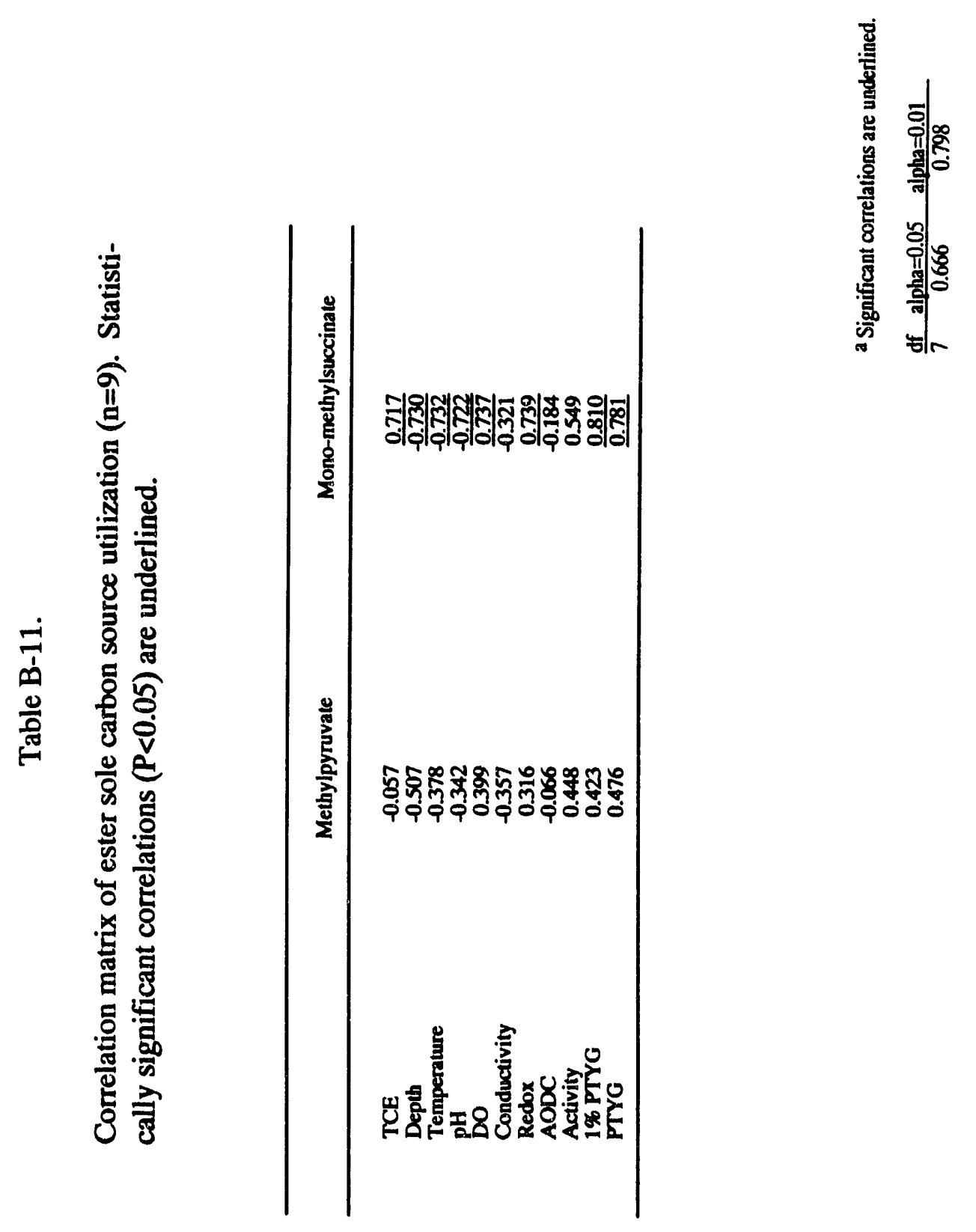



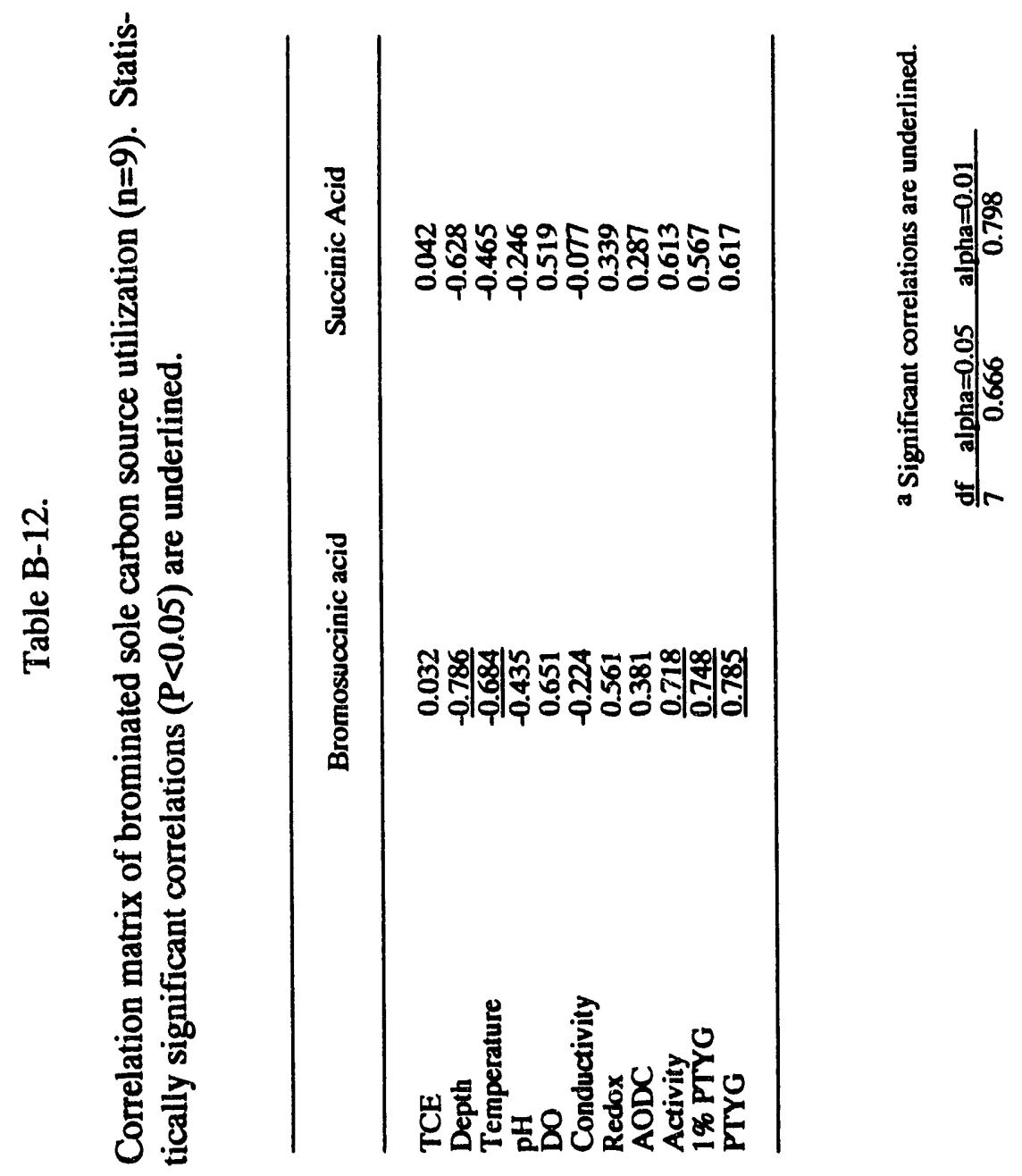


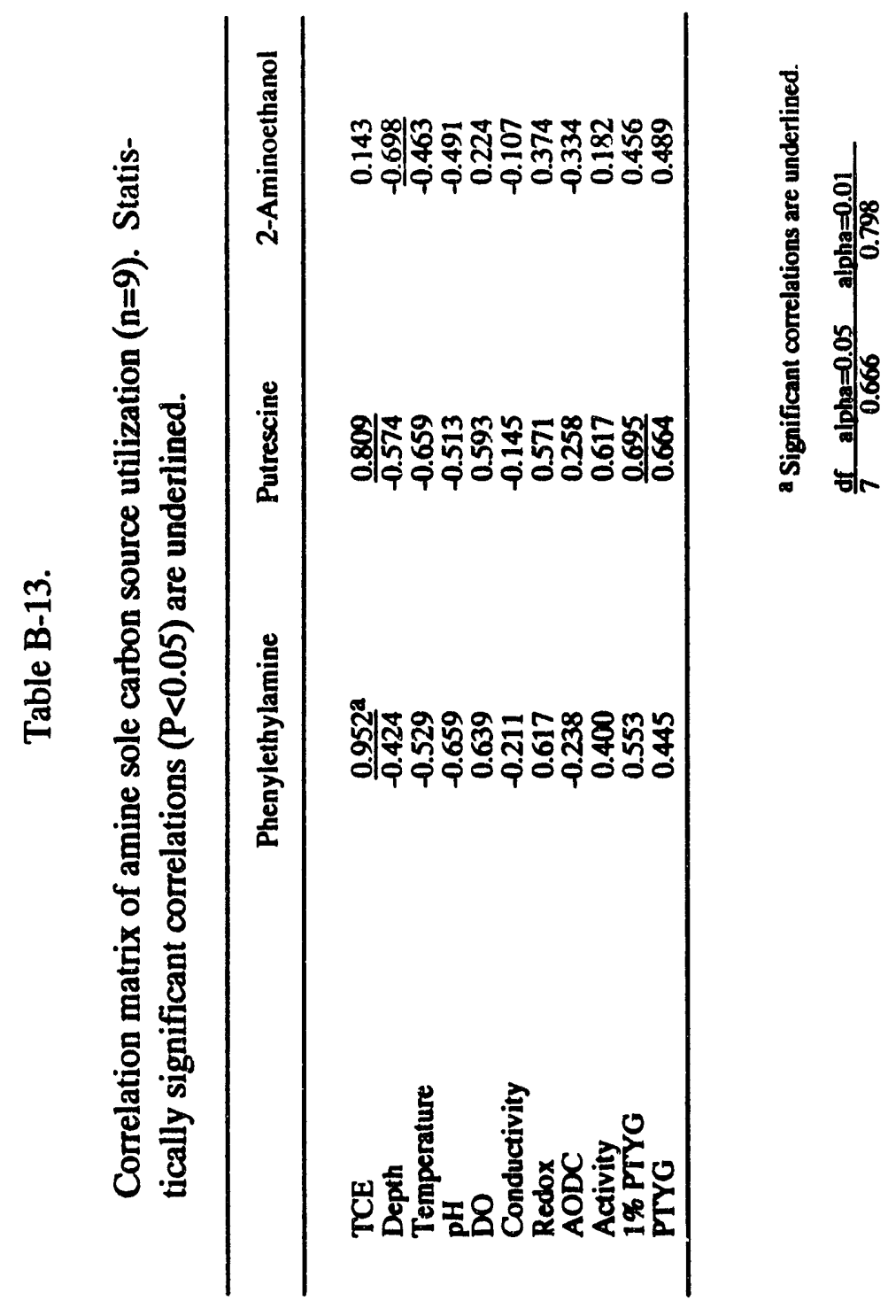




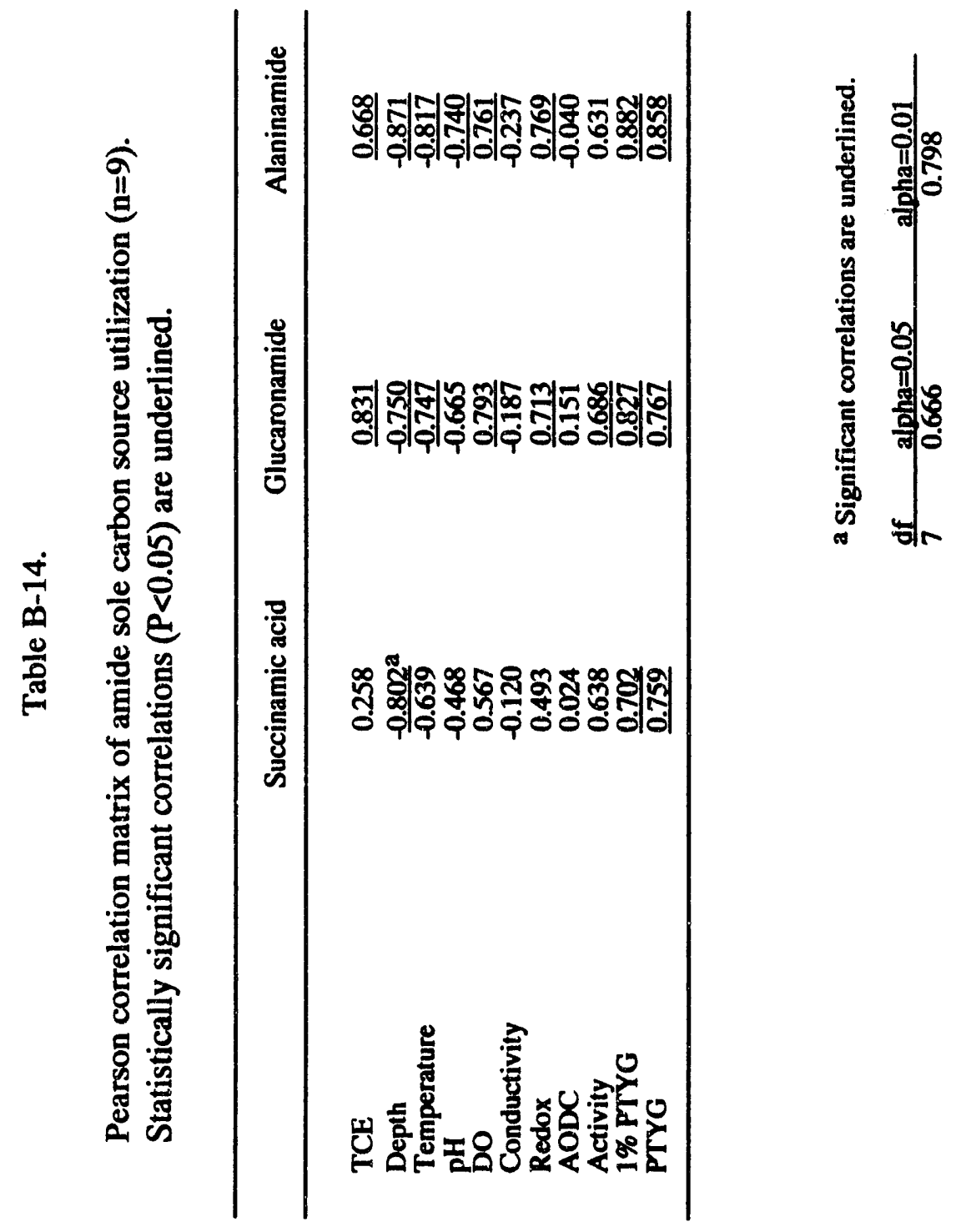




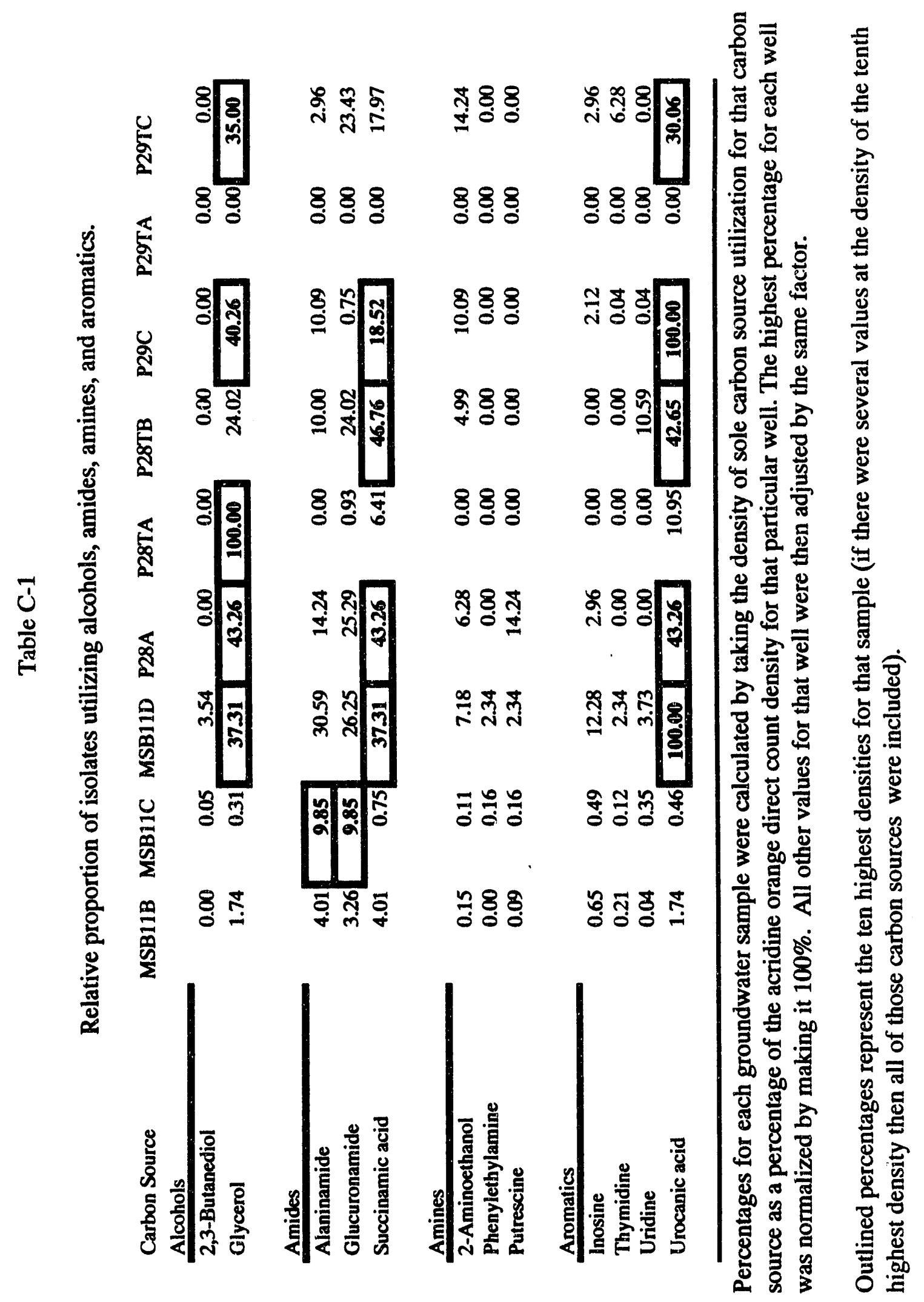




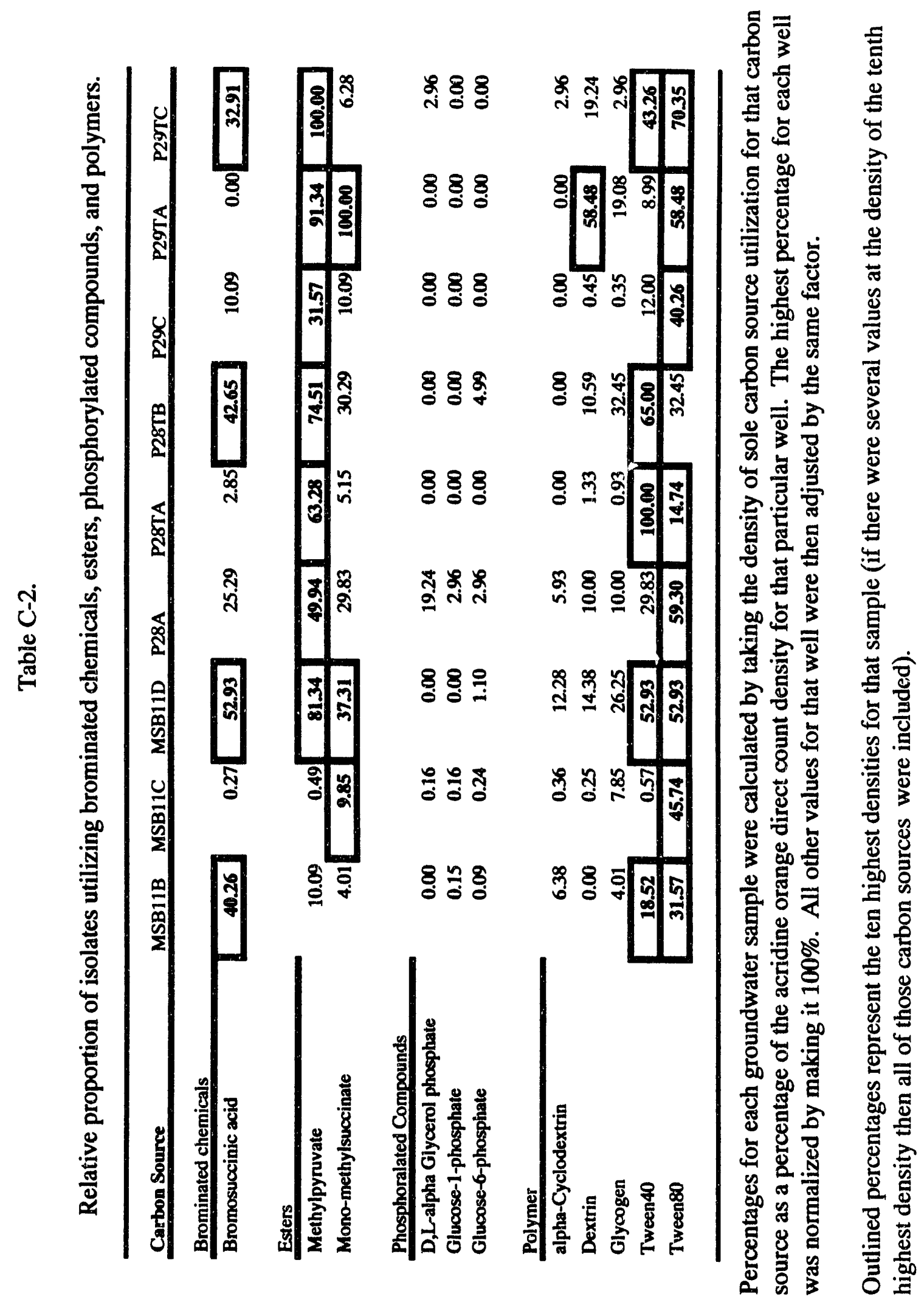




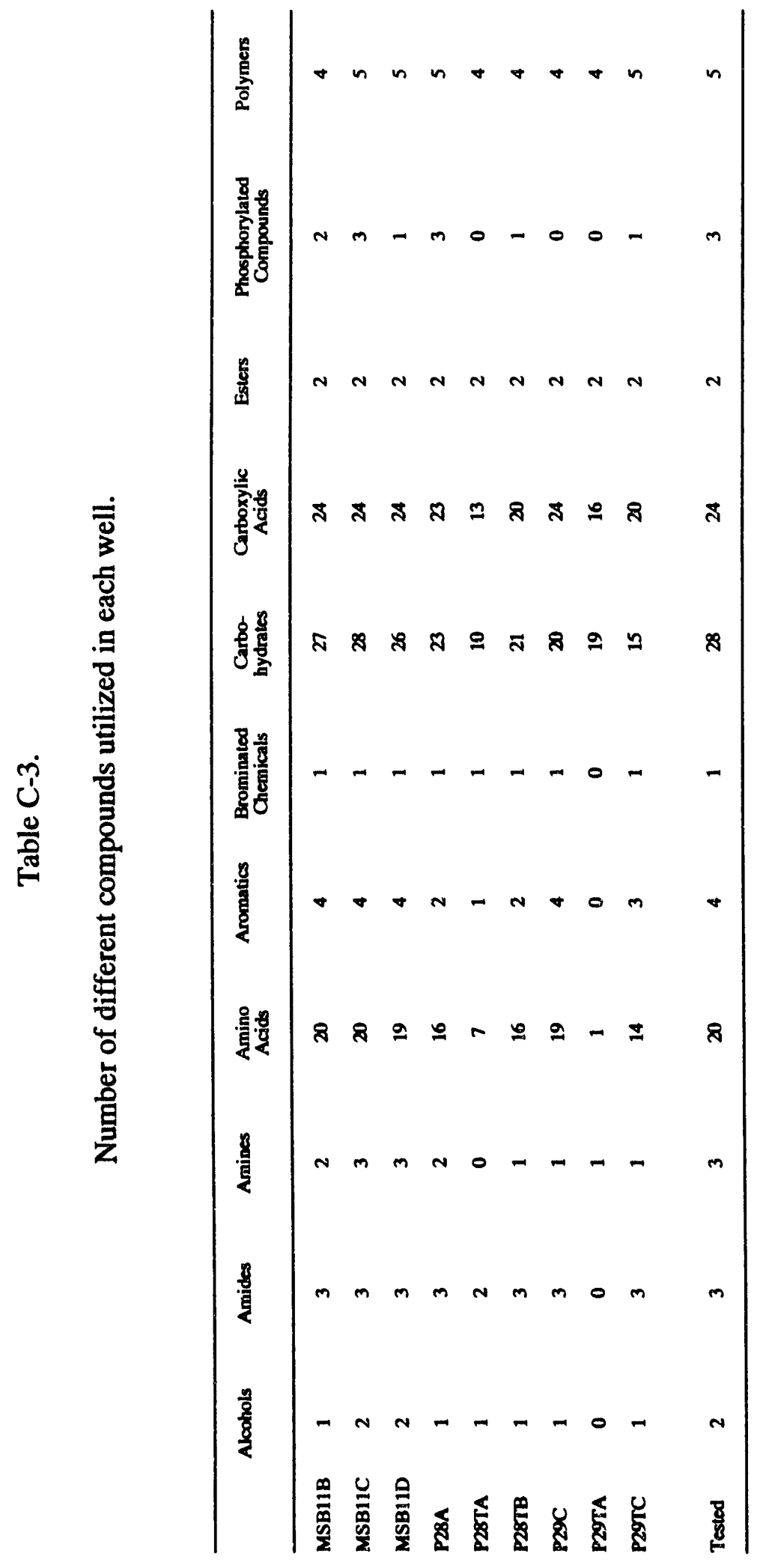


Table D-1

Utilization of p-coumarate by ground water bacteria.
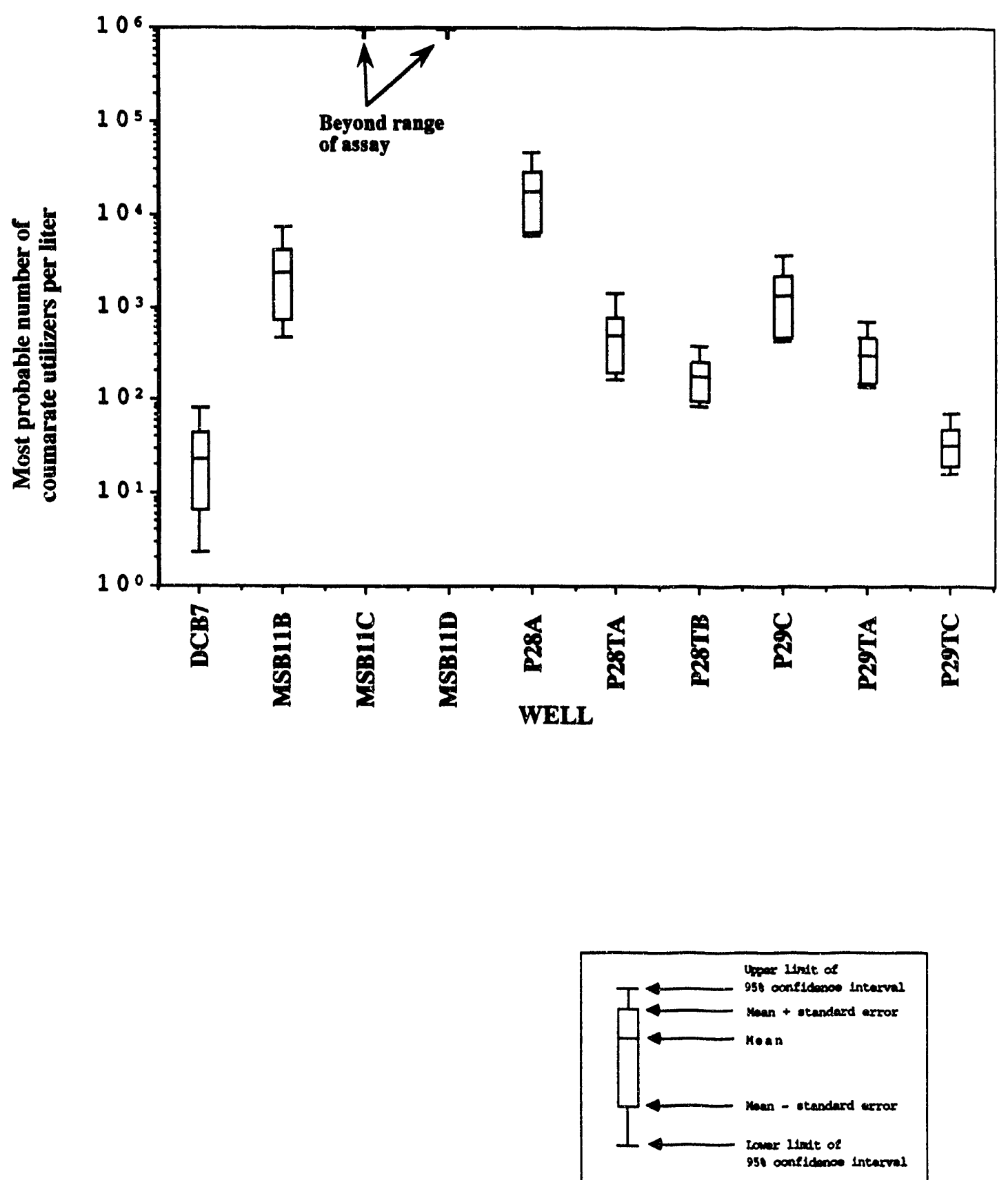
Table D-2

Utilization of ferulate by ground water bacteria.
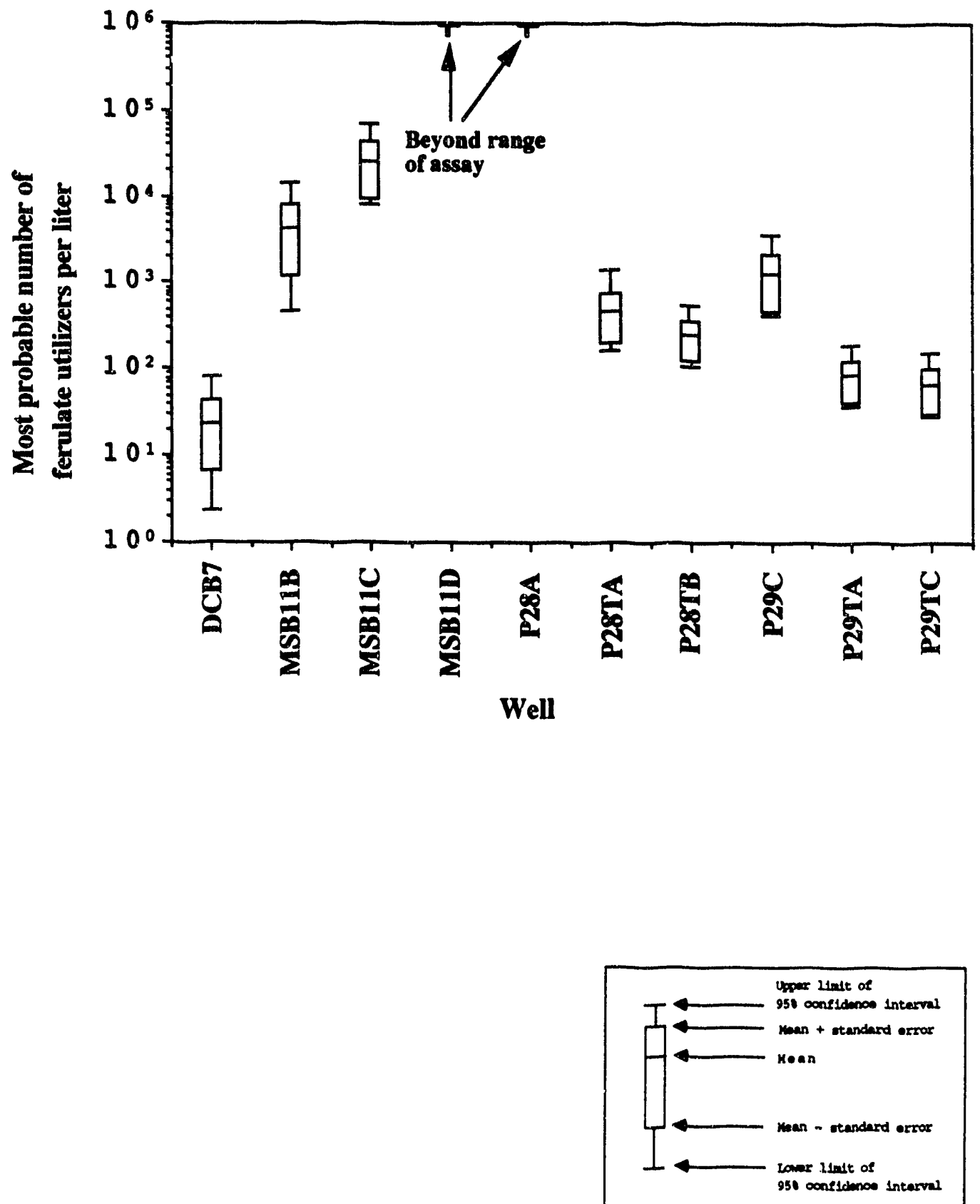


\section{Table D-3}

Utilization of isovanillate by ground water bacteria.
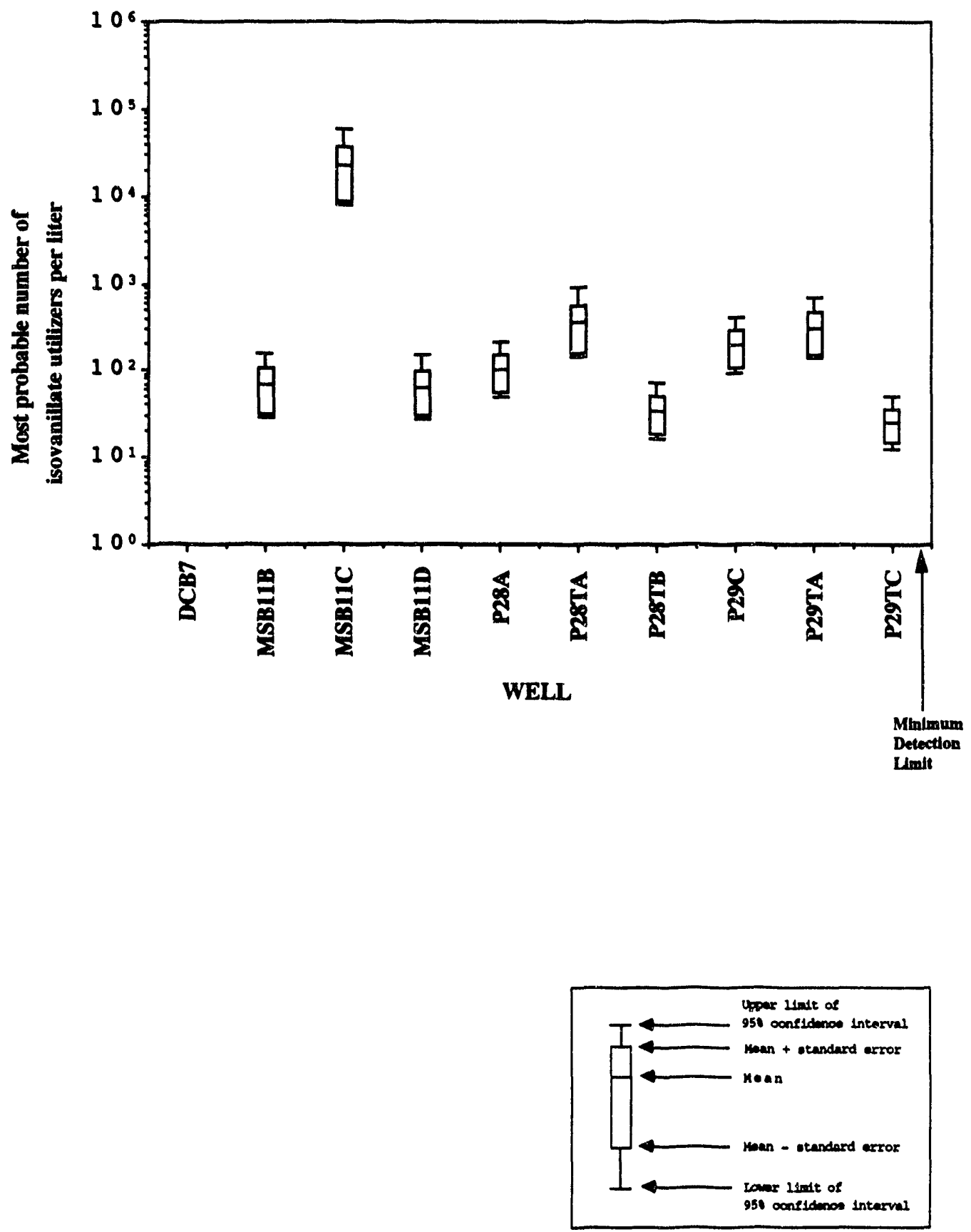
Table D-4

Utilization of salicylate by ground water bacteria.

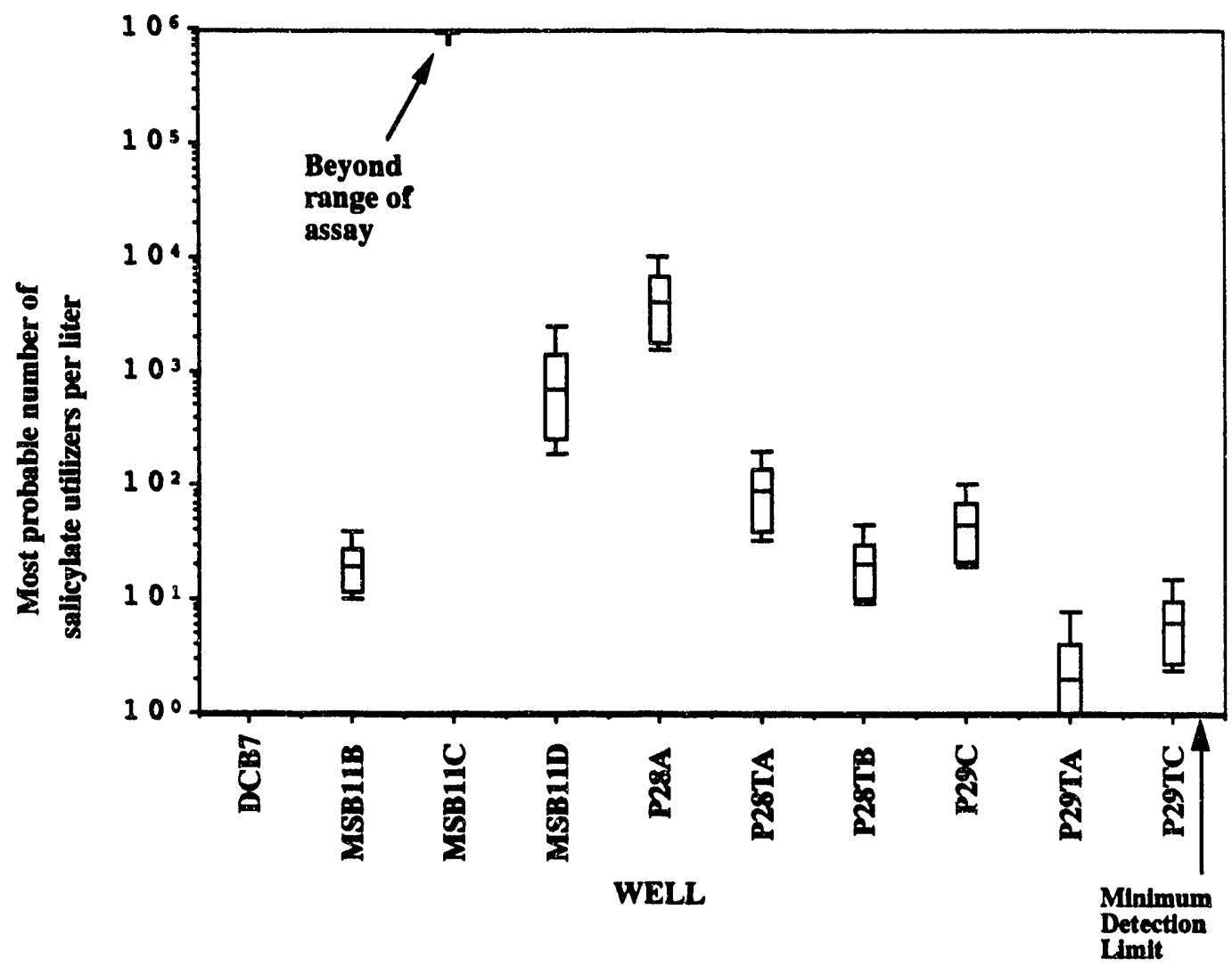




\section{Table D-5}

Utilization of phenol by ground water bacteria.

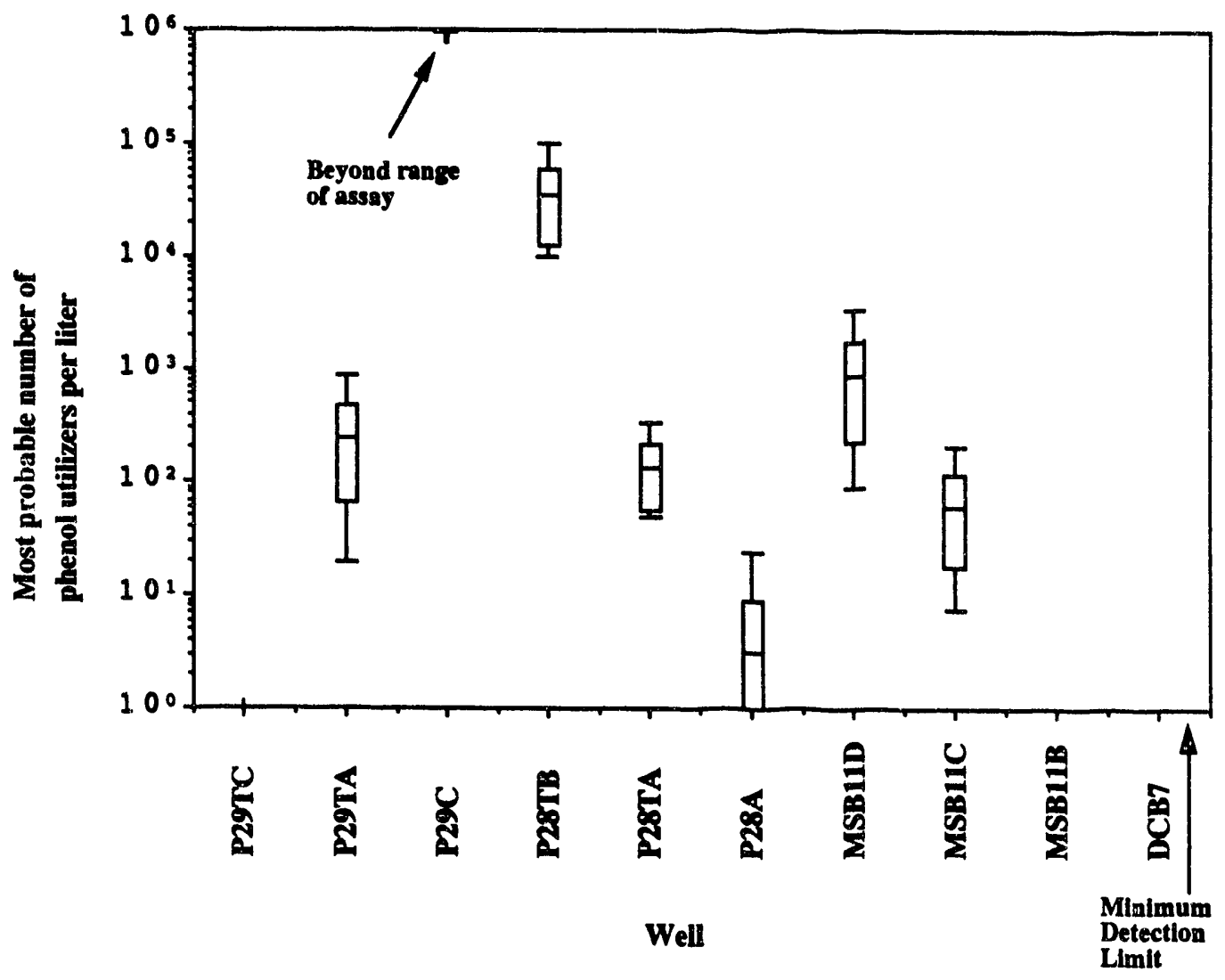


Table D-6.

Utilization of m-toluate by ground water bacteria.
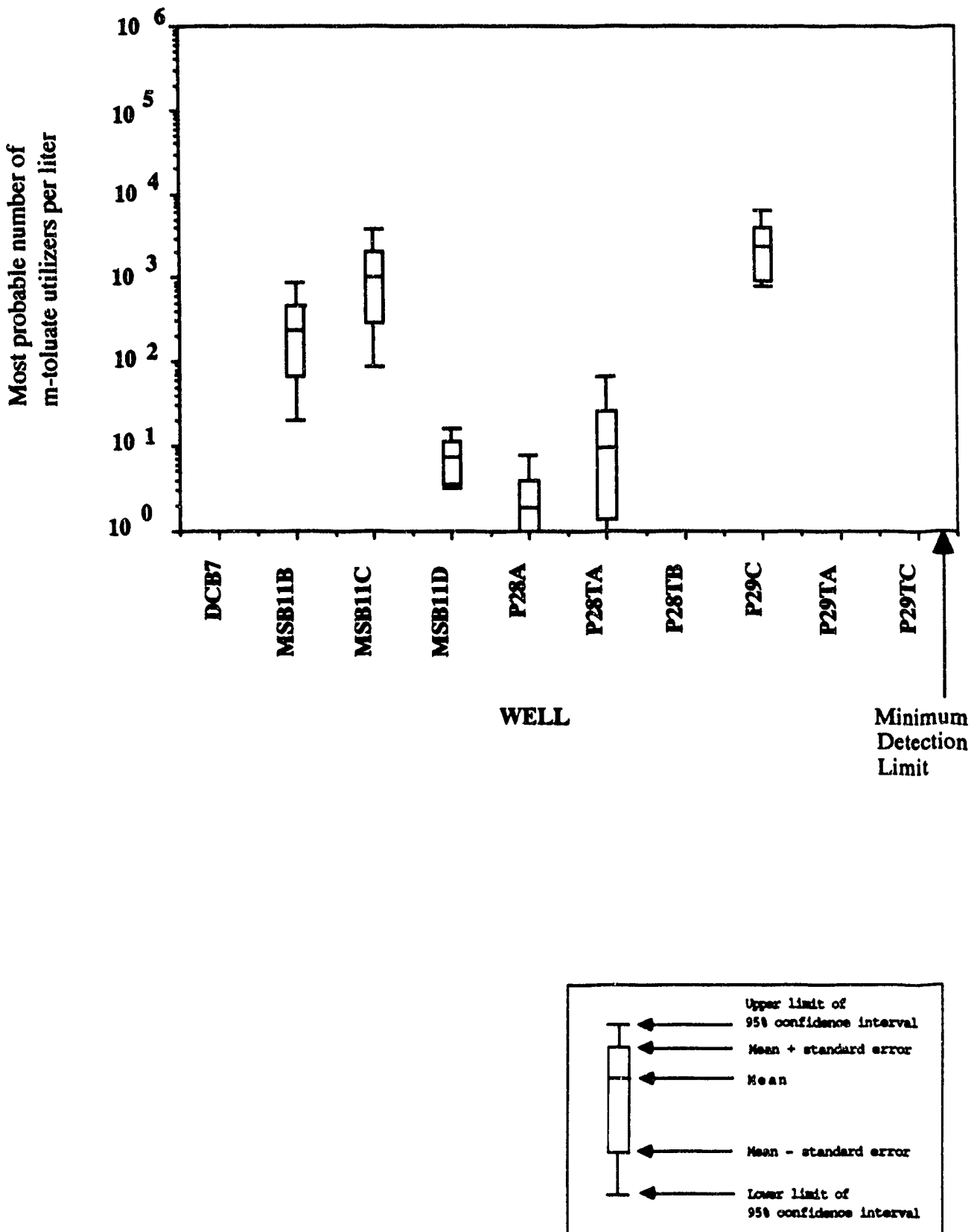


\section{Table E.}

Modification of Stanier's minimal media (Stanier et al., 1966) used for the determination of aromatic utilization by ground water bacteria in this study.

Minimal media:

Ammonium sulfate $\left[\left(\mathrm{NH}_{4}\right)_{2} \mathrm{SO}_{4}\right]$

Distilled water

\section{$1.0 \mathrm{gm}$}

bring to $930 \mathrm{ml}$

autoclave

$1 \mathrm{M} \mathrm{Na} 2 \mathrm{HPO}_{4}+\mathrm{KH}_{2} \mathrm{PO}_{4}$ buffer $\mathrm{pH} 6.8$ (filter sterilized)

$40 \mathrm{ml}$

Mineral base (filter sterilized)

$20 \mathrm{ml}$

Carbon source $1 \mathrm{~g} / 100 \mathrm{ml} \mathrm{H} 2 \mathrm{O}$ (filter sterilized)

$10 \mathrm{ml}$

Mineral base:

$1.0 \mathrm{M} \mathrm{KH}_{2} \mathrm{PO}_{4} \mathrm{pH} 6.8$

Concentrated base

$20 \mathrm{ml}$

Distilled water

$20 \mathrm{ml}$

to $1000 \mathrm{ml}$

filter sterilize

\section{Concentrated base:}

Nitrilotriacetic acid $\left[\mathrm{N}\left(\mathrm{CH}_{2} \mathrm{COOH}\right)_{3}\right]$

Magnesium sulfate $\left[\mathrm{MgSO}_{4}\right]$

$10.0 \mathrm{~g}$

Calcium chloride $\left[\mathrm{CaCl}_{2} \cdot 2 \mathrm{H}_{2} \mathrm{O}\right]$

$14.45 \mathrm{~g}$

Ammonium molybdate $\left[\left(\mathrm{NH}_{4}\right)_{6}\right.$

$3.335 \mathrm{~g}$

Ferrous sulfate $\left[\mathrm{FeSO} \mathrm{S}_{4} \cdot 7 \mathrm{H}_{2} \mathrm{O}\right]$

$9.25 \mathrm{mg}$

Nicotinic acid (niacin) $\left[\mathrm{C}_{5} \mathrm{H}_{4} \mathrm{NCOOH}\right]$

$99.0 \mathrm{mg}$

Thiamin $\cdot \mathrm{HCL}\left[\mathrm{C}_{12} \mathrm{H}_{17} \mathrm{ClN}_{4} \mathrm{OS} \cdot \mathrm{HCL}\right]$

$50.0 \mathrm{mg}$

Biotin $\left[\mathrm{C}_{10} \mathrm{H}_{16} \mathrm{~N}_{2} \mathrm{O}_{3} \mathrm{~S}\right]$

Metals (see below)

$25.0 \mathrm{mg}$

$0.5 \mathrm{mg}$

$50.0 \mathrm{ml}$

Distilled water

to $1000 \mathrm{ml}$

filter sterilize

Metals:

Zinc Sulfate $\left[\mathrm{ZnSO}_{4} \cdot 7 \mathrm{H}_{2} \mathrm{O}\right]$

$1095 \mathrm{mg}$

Ferrous sulfate $\left[\mathrm{FeSO}_{4} \cdot 7 \mathrm{H}_{2} \mathrm{O}\right]$

$500.0 \mathrm{mg}$

Manganous sulfate $\left[\mathrm{MnSO}_{4} \cdot 4 \mathrm{H}_{2} \mathrm{O}\right.$ ]

$154 \mathrm{mg}$

Copper sulfate [ $\mathrm{CuSO}_{4} \cdot 5 \mathrm{H}_{2} \mathrm{O}$ ]

$39.2 \mathrm{mg}$

Cobaltous nitrate $\left[\mathrm{Co}\left(\mathrm{NO}_{3}\right)_{2} \cdot 6 \mathrm{H}_{2} \mathrm{O}\right]$

$24.8 \mathrm{mg}$

Sodium borate $\left[\mathrm{Na}_{2} \mathrm{~B}_{4} \mathrm{O}_{7} \cdot 10 \mathrm{H}_{2} \mathrm{O}\right.$ ]

Sulfuric acid $\left[\mathrm{H}_{2} \mathrm{SO}_{4}\right]$

$17.7 \mathrm{mg}$

Distilled water

a few drops to retard precipitation 

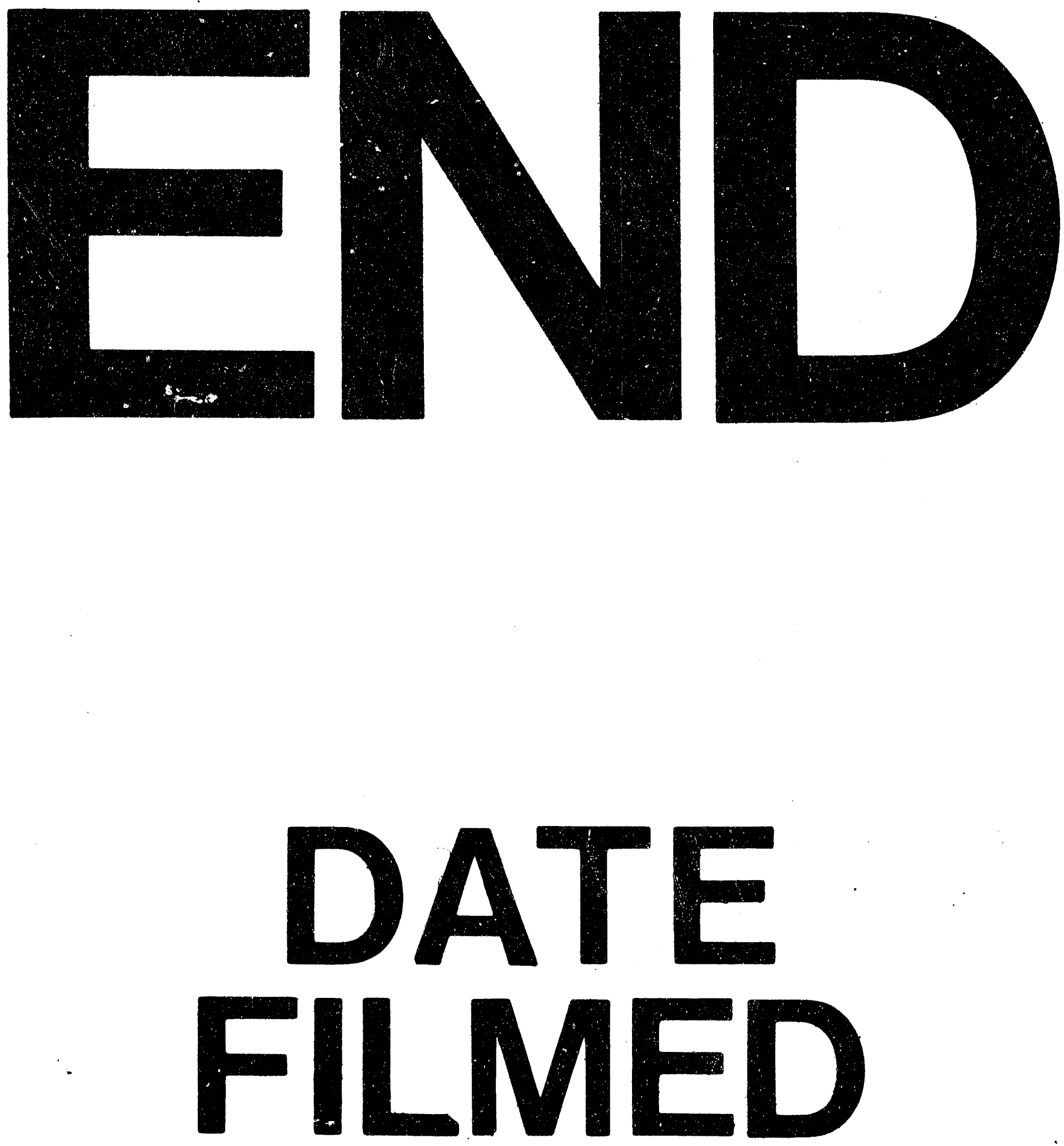

I

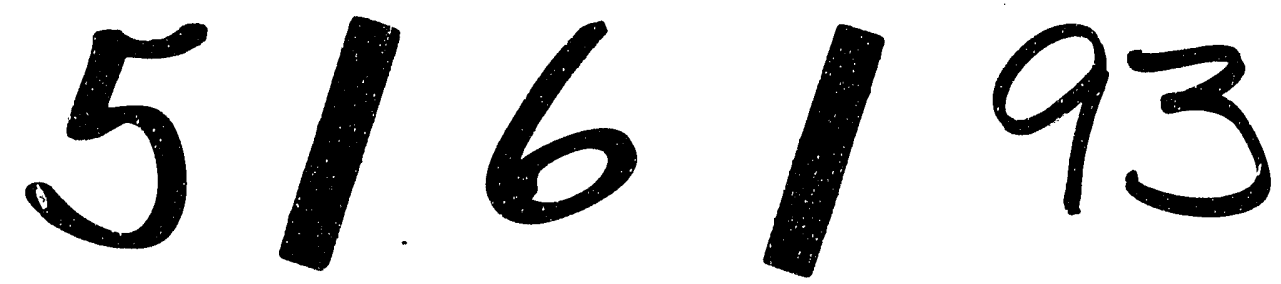


